\title{
Potential Radiological Impacts of Upper-Bound Operational Accidents During Proposed Disposal Alternatives for Hanford Defense Waste
}
J. Mishima
S. L. Sutter
K. A. Hawley
C. E. Jenkins
B. A. Napier

February 1986

Prepared for the U.S. Department of Energy under Contract DE-AC06-76RLO 1830

Pacific Northwest Laboratory Operated for the U.S. Department of Energy by Battelle Memorial Institute 


\title{
DISCLAIMER
}

This report was prepared as an account of work sponsored by an agency of the United States Government. Neither the United States Government nor any agency thereof, nor any of their employees, makes any warranty, express or implied, or assumes any legal liability or responsibility for the accuracy, completeness, or usefulness of any information, apparatus, product, or process disclosed, or represents that its use would not infringe privately owned rights. Reference herein to any specific commercial product, process, or service by trade name, trademark, manufacturer, or otherwise, does not necessarily constitute or imply its endorsement, recommendation, or favoring by the United States Government or any agency thereof. The views and opinions of authors expressed herein do not necessarily state or reflect those of the United States Government or any agency thereof.

\author{
PACIFIC NORTHWEST LABORATORY \\ operated by \\ BATTELLE \\ for the \\ UNITED STATES DEPARTMENT OF ENERGY \\ under Contract DE-AC06-76RLO 1830
}

\begin{tabular}{|c|c|}
\hline \multirow{2}{*}{\multicolumn{2}{|c|}{ Printed in the United States of America }} \\
\hline & \\
\hline \multicolumn{2}{|c|}{$\begin{array}{l}\text { Available from } \\
\text { National Technical Information Service }\end{array}$} \\
\hline \multicolumn{2}{|c|}{ United Srates Department of Commerce } \\
\hline \multirow{2}{*}{\multicolumn{2}{|c|}{$\begin{array}{l}\text { 5285 Port Royal Road } \\
\text { 5pringfield, Virginia } 22761\end{array}$}} \\
\hline & \\
\hline \multirow{2}{*}{\multicolumn{2}{|c|}{$\begin{array}{l}\text { NTIS Price Codes } \\
\text { Microtiche A01 }\end{array}$}} \\
\hline & \\
\hline \multicolumn{2}{|c|}{ Printed Copy } \\
\hline & Price \\
\hline Pages & Codes \\
\hline $001-025$ & A02 \\
\hline $026-050$ & $A 03$ \\
\hline $051-075$ & AOA \\
\hline $076-100$ & AOS \\
\hline $101-125$ & 106 \\
\hline $126-150$ & $A 07$ \\
\hline $151-175$ & A08 \\
\hline 176.200 & A09 \\
\hline $201-225$ & A010 \\
\hline $226 \cdot 250$ & A011 \\
\hline $251-275$ & $A 012$ \\
\hline $276-300$ & A013 \\
\hline
\end{tabular}


POTENTIAL RADIOLOGICAL IMPACTS OF UPPER-BOUND DPERATIONAL ACCIOENTS DURING PROPOSED WASTE DISPOSAL ALTERNATIVES FOR HANFORD DEFENSE WASTE
J. Mishina
S. L. Sutter
K. A. Hawley
C. E. Jankins (a)
B. A. Napier

February 1986

Prepared for

the U,S. Department of Energy

under Contract DE-ACO6-7 ORLO 1830

Pacitic Northwest Laboratory

Richland, Washington 99352

(a) Science Applications Intemational Corporation Richland, Wastington 99352 


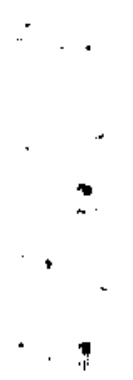

$?$

$\therefore$

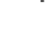

$-$ 


\section{FOREWORD}

This document was prepared to present more detail with respect to operational accidents than could reasonably be contained in Appendix $H$, "Radiation Doses to the Pubtic from Operational Accidents," contained in the environmental impact statement pertaining to disposal of Hanford high-level, transuranic and tank wastes, DOE/EIS-0113, to be issued in 1986. 
" 
SUMMARY

Three alternatives are being evaluated for disposal of Hanford defense high-level, transuranic, and tank wastes. The wastes have been identified existing tank waste, future tank waste, cesium and strontium capsules, transuranic (TRU) contaminated soi 1, pre-1970 buried TRU solids, and retrievably stored and newly generated TRU solid waste. The three alternatives are the Geologic Disposal Alternative, the In-Place Stabilization and Disposal Alternative and the Reference Disposal Alternative.

Environmental impacts associated with disposal of these wastes according to the alternatives listed above include potential doses to the downwind population from operation during the application of the handling and processing techniques comprising each disposal alternative. Scenarios for operational accident and abnormal operational events are postulated, on the basis of the currently available information, for the application of the techniques employed for each waste class for each disposal alternative. From these scenarios, an upper-bound airborne release of radioactive material was postulated for each waste class and disposal alternative. Potential downind radiologic impacts were calculated from these upper-bound events.

The dose to the maximally exposed individual and the total downwind population dose were obtained by using standard radionuclide transport and dose computer codes. The meteorological data used for the transport were selected from data collected at the Hanford Site over many years. Demographic data for the locale was taken from published information.

In all three alternatives, the single postulated event with the largest calculated radiologic impact for any waste class is an explosion of a mixture of ferri/ferro cyanide precipitates during the mechanical retrieval or microwave drying of the salt cake in single shell waste tanks. The anticipated downwind dose (70-year dose commitment) to the maximally exposed individual is 3 rem with a total population dose of 7000 man-rem. The same individual would receive 7 rem from natural background radiation during the same time period, and the same population would receive 3,000,000 man-rem. Radiological impacts to the public from all other postulated accidents would be less than that from 
this accident; furthermore, the radiological impacts resulting from this accident would be less than one-half that from the natural background radiation dose. Since this is the postulated accident for each of the disposal alternatives, operational accidents in general should not constitute an important discrimination among alternatives. 


\section{CONTENTS}

FOREWORD.

SUMMARY

1.0 INTRODUCTION $\ldots \ldots \ldots \ldots \ldots \ldots \ldots \ldots \ldots \ldots \ldots \ldots \ldots \ldots \ldots \ldots \ldots \ldots \ldots \ldots \ldots \ldots$

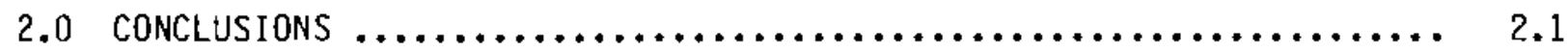

3.0 TECHNICAL APPROACH AND METHODS $\ldots \ldots \ldots \ldots \ldots \ldots \ldots \ldots \ldots \ldots \ldots \ldots \ldots \ldots \ldots$

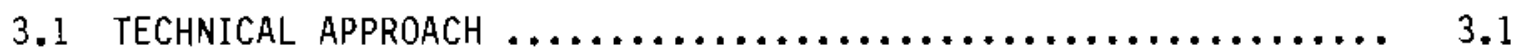

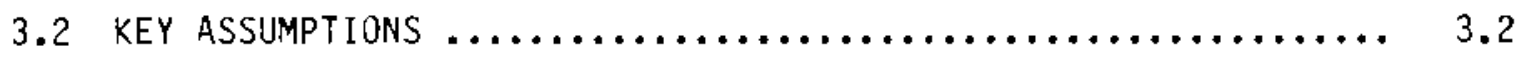

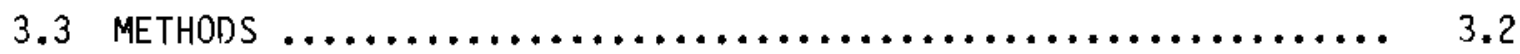

4.0 WASTE FORMS AND DISPOSAL ALTERNATIVES $\ldots \ldots \ldots \ldots \ldots \ldots \ldots \ldots \ldots \ldots . \ldots \ldots$

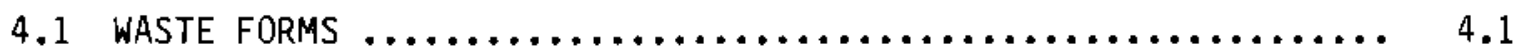

4.1 .1 Existing Tank Waste $\ldots \ldots \ldots \ldots \ldots \ldots \ldots \ldots \ldots \ldots \ldots \ldots . \ldots . \ldots . \ldots$

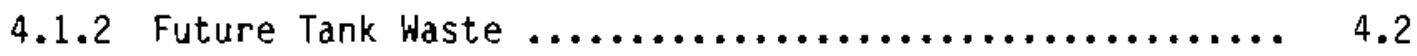

4.1 .3 Strontium and Cesium Capsules ................ 4.4

4.1 .4 TRU-Contaminated Soil $\ldots \ldots \ldots \ldots \ldots \ldots \ldots \ldots \ldots \ldots \ldots \ldots . \ldots \ldots$

4.1.5 Pre-1970 TRU Solid Waste Burial Ground ........... 4.6

4.1 .6 Retrievably Stored and Newly Generated TRU
Solid Waste $\ldots \ldots \ldots \ldots \ldots \ldots \ldots \ldots \ldots \ldots \ldots \ldots \ldots \ldots \ldots \ldots \ldots$

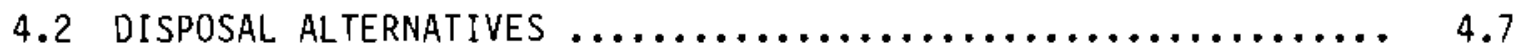

4.2 .1 Geologic Disposal Alternative ................ 4.9

4.2.2 In-Place Stabilization and Disposal Alternative ..... 4.10

4.2.3 Reference Alternative .................... 4.13

4.2 .4 No Disposal Alternative ................... 4.13

5.0 POSTULATED RELEASES FROM POTENTIAL ACCIDENTS ASSOCIATED

WITH THE GEOLOGIC DISPOSAL OF SIX WASTE FORMS $\ldots \ldots \ldots \ldots \ldots \ldots \ldots \ldots .1$

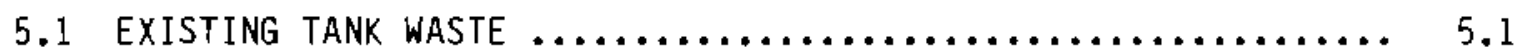


5.1 .1 Mechanical Retrieval $\ldots \ldots \ldots \ldots \ldots \ldots \ldots \ldots \ldots \ldots \ldots . . .6 .1$

5.1 .2 Hydraulic Retrieval $\ldots \ldots \ldots \ldots \ldots \ldots \ldots \ldots \ldots \ldots \ldots, 5.7$

$5,1.3$ Radionuclide Concentration ....................... 5.11

5.1 .4 Glass Immobitization $\ldots \ldots \ldots \ldots \ldots \ldots \ldots \ldots \ldots \ldots \ldots \ldots .6 .17$

5.1 .5 Grout Decontaminated Salt Solutions ............... 5.22

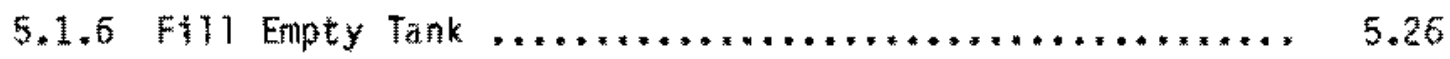

5.2 FUTURE TANK WASTE $\ldots \ldots \ldots \ldots \ldots \ldots \ldots \ldots \ldots \ldots \ldots \ldots \ldots \ldots .30$

5.2 .1 Retrieval .................................. 5.30

5.2.2 Solid/Liquid Separation and Strontium, Cesiun,
Technetium and TRU Removal ........................ 5.30

5.2 .3 Grout Decontaminated Liquid ...................... 5.30

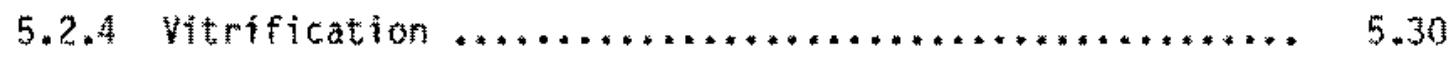

5.2 .5 Fill Empty Tanks $\ldots \ldots \ldots \ldots \ldots \ldots \ldots \ldots \ldots \ldots \ldots \ldots, 5.3 !$

5.3 STRONTIUM ANO CESTUM CAPSULES ......................... 5.31

5.3 .1 Removal of Capsules from Water Bas in ............... 5.31

5.3 .2 Capsule Packaging.................................. 5.35

5.4 TRU-CONTAMINATEd SOLL .............................. 5.37

5.A.1 Mechanical Retrieval of TRll-Contaminated Soil ........ 5.37

5.4 .2 Processing ....................................... 5.41

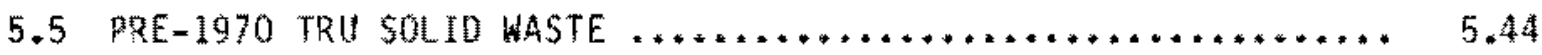

5.5.1 Mechanical Retrieval of Pre-1970 TRU Solid Waste ...... 5.44

5.5 .2 Sorting and Related Operations .................... 5.45

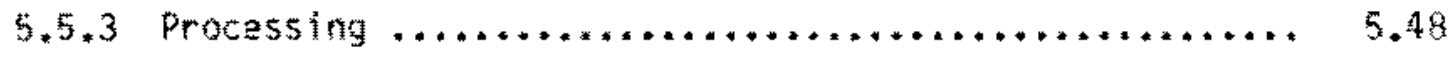

5.6 RETRIEVABLY STOREO AND NEWLY GENERATED TRII $\ldots \ldots \ldots \ldots \ldots \ldots \ldots, 5.49$

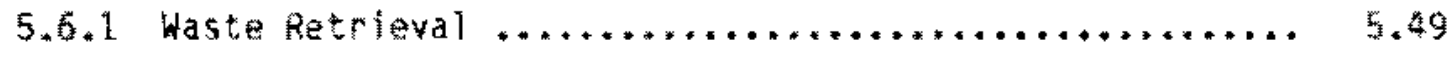

5.6.2 Sorting and Related Operations .................... 5.54 
5.6 .3 Processing $. \ldots \ldots \ldots \ldots \ldots \ldots \ldots \ldots \ldots \ldots \ldots \ldots \ldots \ldots, \quad 5.54$

6.0 POSTULATED RELEASES FROM POTENTIAL ACC IDENTS ASSOCIATED

WITH IN-PLACE STABILIZATIDN AND DISPOSAL OF SIX WASTE FORMS $\ldots \ldots \ldots .6 .1$

6.1 EXISTING TANK WASTE $\ldots \ldots \ldots \ldots \ldots \ldots \ldots \ldots \ldots \ldots \ldots \ldots \ldots \ldots \ldots, 6.1$

6.1 .1 Dry Single-Shell Tanks $\ldots \ldots \ldots \ldots \ldots \ldots \ldots \ldots \ldots \ldots, 6.1$

6.1 .2 Tank Dome Filling ............................ 6.4

6.1 .3 Hydraulic Retrieval of Residual Liquid ............ 6.5

6.1 .4 Complexant Destruction $\ldots \ldots \ldots \ldots \ldots \ldots \ldots \ldots \ldots \ldots \ldots, 6.6$

6.1 .5 Grout $\ldots \ldots \ldots \ldots \ldots \ldots \ldots \ldots \ldots \ldots \ldots \ldots \ldots \ldots \ldots \ldots \ldots \ldots \ldots \ldots \ldots, 6.6$

6.1.6 Trench Disposal of Grout $\ldots \ldots \ldots \ldots \ldots \ldots \ldots \ldots \ldots \ldots, 6.7$

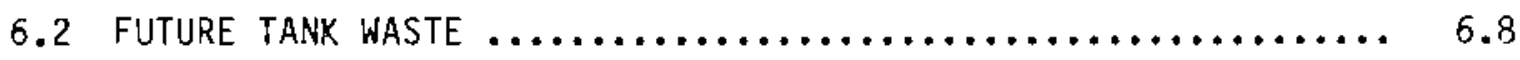

6.2 .1 Hydraulic Retrieval $\ldots \ldots \ldots \ldots \ldots \ldots \ldots \ldots \ldots \ldots \ldots, 6.8$

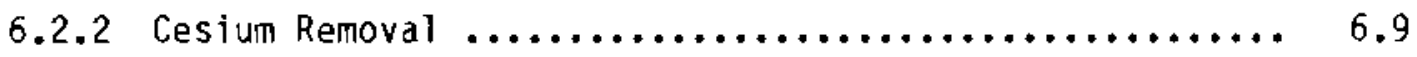

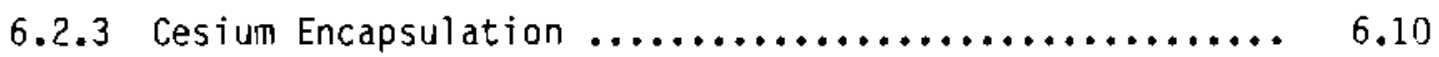

6.2.4 Grouting Neutralized Current Acid Waste Supernant
Liquids ....................................... 6.14

6.2 .5 Fill Tank $\ldots \ldots \ldots \ldots \ldots \ldots \ldots \ldots \ldots \ldots \ldots \ldots \ldots \ldots \ldots, 6.15$

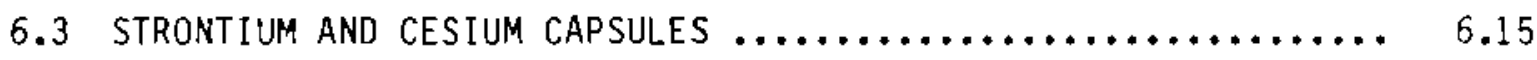

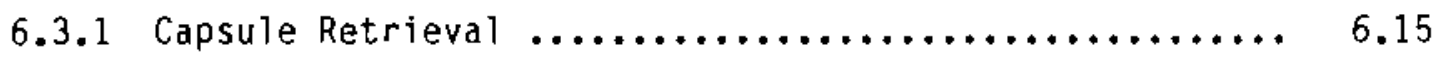

6.3.2 Capsule Packaging $\ldots \ldots \ldots \ldots \ldots \ldots \ldots \ldots \ldots \ldots \ldots \ldots, 6.16$

6.3.3 Place Capsules in Drywel1 Storage ................ 6.16

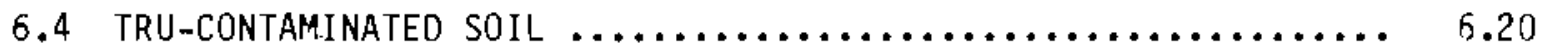

6.4 .1 Grout Injection $\ldots \ldots \ldots \ldots \ldots \ldots \ldots \ldots \ldots \ldots \ldots, 6.20$

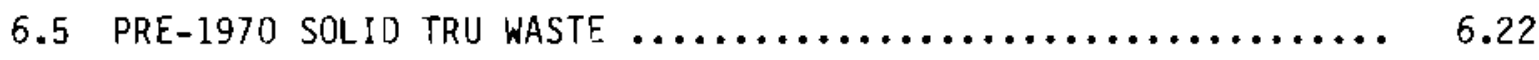

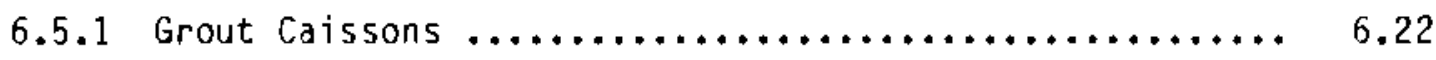

6.5 .2 Subsidence Control $\ldots \ldots \ldots \ldots \ldots \ldots \ldots \ldots \ldots \ldots \ldots, 6.24$ 
6.6 RETRIEVABLY STOREO AND NEWLY GENERATED TRU SOLID WASTE „.... 6.25

6.6 .1 Waste turial $\ldots \ldots \ldots \ldots * \ldots \ldots \ldots \ldots \ldots \ldots \ldots \ldots \ldots \ldots \ldots_{6.26}$

7.0 POSTULATED RELEASES FROM OPERAT IONAL ACCIDENTS ASSOCIATED

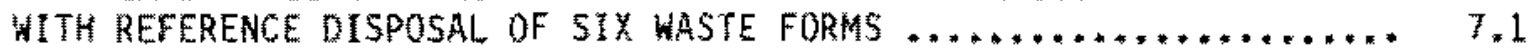

7.1 DOUBLE-SHELL TANK WASTE $\ldots \ldots \ldots \ldots \ldots \ldots \ldots \ldots \ldots \ldots \ldots \ldots \ldots \ldots \ldots 7.1$

7.2 FUTURE TANK WASTE $\ldots \ldots \ldots \ldots \ldots \ldots \ldots \ldots \ldots \ldots \ldots \ldots \ldots \ldots \ldots \ldots \ldots \ldots \ldots \ldots+2$

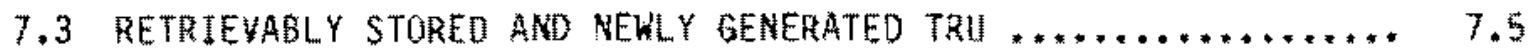

8.0 POSTULATED RELEASES FROM OPERATIONAL ACCIOENTS ASSOCIATED WITH

THE NO DISPOSAL ACTION ALTERNATIVE $\ldots \ldots \ldots \ldots \ldots \ldots \ldots \ldots \ldots \ldots \ldots \ldots \ldots \ldots$

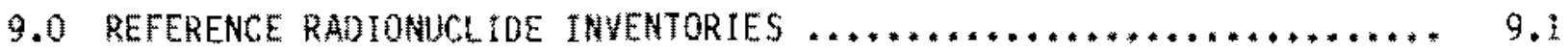

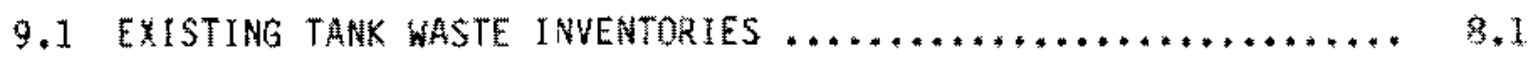

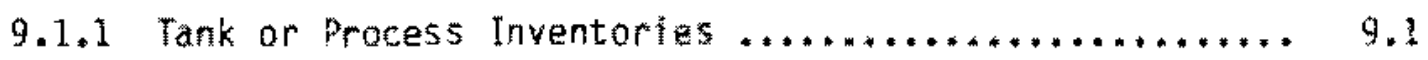

9.1 .2 Grott and Glass Inventories ................... 9.1

9.2 FUTURE TANK WASTE - REFERENCE RAOIONUCLIDE INVENTORIES ..... 9.4

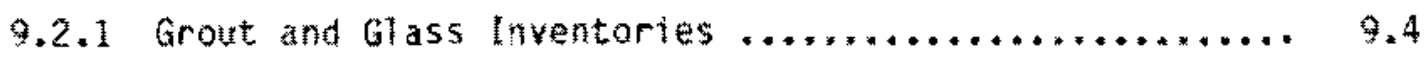

9.3 CESIUM AND STRONTIUM EAPSULE INVENTORIES $\ldots \ldots \ldots \ldots \ldots \ldots \ldots \ldots .9 .4$

9.4 TRU CONTAMIMAFEO SOIL SITES - REFERENCE RADIONUCLIDE

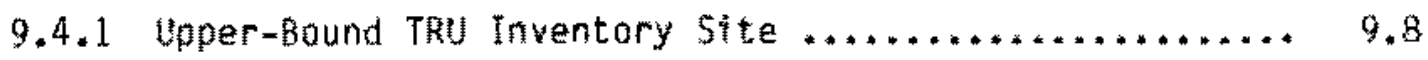

9.4 .2 Upperwbund Fission Product Stte ................ 9.11

9.4 .3 Upper-Bound ThU Concentration $\ldots \ldots \ldots \ldots \ldots \ldots \ldots \ldots \ldots . \ldots .12$

9.5 PRE-1970 TRL SOLLD WASTE BURIAL GROUND - REFERENCE

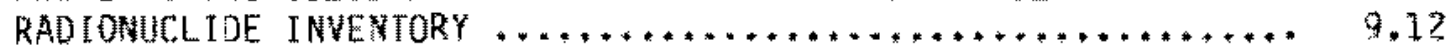

9.5 .1 Upper-Bound Thu Inventory Site $\ldots \ldots \ldots \ldots \ldots \ldots \ldots \ldots \ldots . . \ldots .12$

9.5.2 Upper-Bound Fission Product Inventory site ......... 9.13

9.5 .3 Upper-Pound TRU Concentration Site Inventory ........ 9.13

9.6 RETRIEYABLE STORED AND NEWLY GENERATED TRU SOLLD

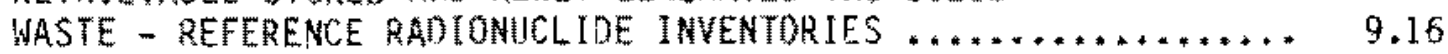


$9.6,1$ Primary site $\ldots \ldots \ldots \ldots \ldots \ldots \ldots \ldots \ldots \ldots \ldots \ldots \ldots \ldots \ldots ., 9.16$

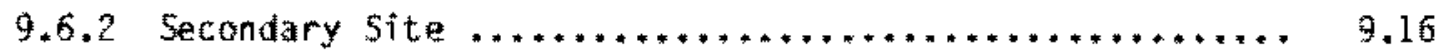

9.6 .3 Tertiary Site ............................... 9.18

10.0 DOWNWIND TRANSPORT AND DOSE CALCULATIONAL METHODS AND

RADIATION DOSES FROM POSTULATED OPERATIONAL ACCIDENTS ........... 10.1

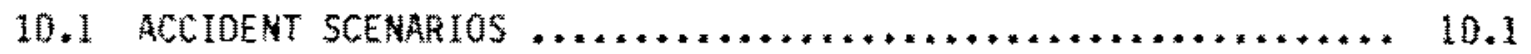

10.2 DOSE CODES ......................................... 10.2

10.3 STANDARD HANFORD METEOROLOGICAL PARAMETERS $\ldots \ldots \ldots \ldots \ldots \ldots, 10.3$

10.4 STANDARD HANFORO EXPOSURE PARAMETERS $\ldots \ldots \ldots \ldots \ldots \ldots \ldots, 10.5$

10.5 RAOIATION DOSE ESTIMATES FROM ACCLDENTAL ATMOSPHERIC

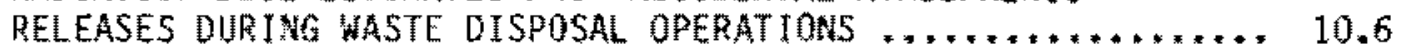

10.5.1 Radiation Doses Associated with Geologic Disposal Alternative ......................... 10.6

10.5.2 Radiation Doses Associated with the In-Place Stabilization Alternative ...................... 10.13

10.5.3 Radiation Doses Associated with the Reference Alternative Disposal Action ....................... 10.13

10.5.4 Radiation Doses Associated with the No Disposal Action Alternative ............................... 10.26

10.5.5 Interpretation of the Radiological Impact from the Waste Disposal Alternatives .................. 10.26

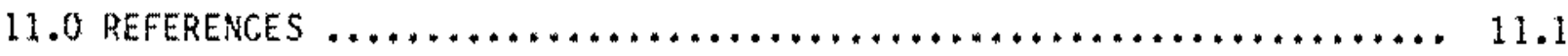





\section{FIGURES}

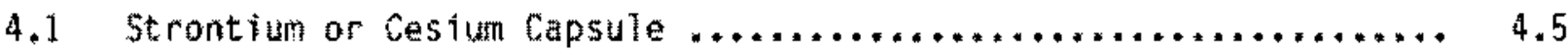

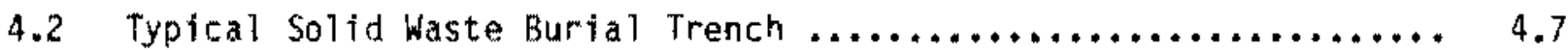

4.3 Caisson for TRU storage $\ldots \ldots \ldots \ldots \ldots \ldots \ldots \ldots \ldots \ldots \ldots \ldots \ldots, 4.8$

4.4 TRu Asphalt Pad Storage .................................... 4.9

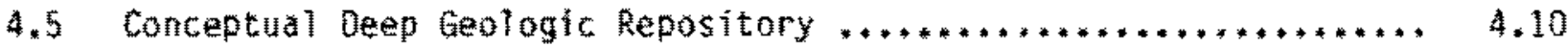

4.6 Schematic of Protective Barrier as Applied to Single-Shell

Tank Waste ................................................ 4.12

5.1 Mechanical Retrieval of Wastes from Single-Sheil Tanks .......... 5.4

5.2 Hydraulic Retrieval of Waste from Double-Shell Tanks ..........., 5.7

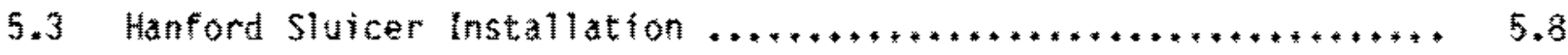

5.4 Schematic Flowsheet for Radionuclide Concentration Processes...... 5.11

5.5 Conceptual Facility for Radionuclide Concentration ............ 5.13

5.6 Continuous Electric Glass Melter ........................ 5.18

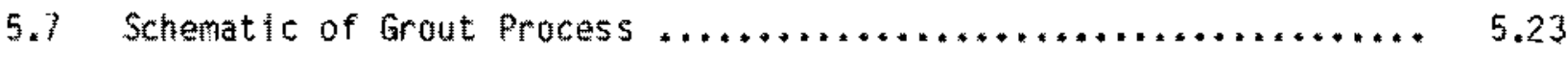

5.8 Near-Surface Trench Di sposal of Grout ..................... 5.24

5.9 Centrifugal Thrower for Filting Waste Tanks $\ldots \ldots \ldots \ldots \ldots \ldots \ldots \ldots .6 .27$

5.10 Mechanical Retrieval of Wastes from Soil or
Solid Waste Sites.......................................... 5.38

5.11 Slagging Pyrolysis Incineration Gasifier and
Conbustion Chamber...................................... 5.42

5.12 Caisson Recovery Bullding, Side View........................ 5.50

5.13 Caisson Recovery Building, Top View........................... 5.51

6.1 Transfer of Strontium and Cesium Capsules from the Capsule
Packaging Facility to the Dry Well Storage Facility ............ 5.17

6,2 Typical Drywe 11 Assembly $\ldots \ldots \ldots \ldots \ldots, \ldots \ldots \ldots \ldots \ldots \ldots \ldots \ldots \ldots, 6.18$ 
10.1 Computer Programs for Calculating Public Doses from

Routine or Aceidental Relexses of Radionuclides During

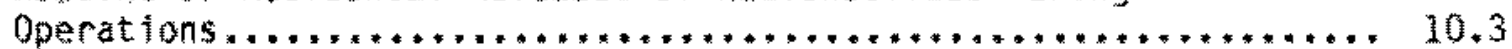




\section{TABLES}

2.1 Summary of Upper-Bound Accidents and Radiation Doses Associated with the Geologic Disposal Alternative of

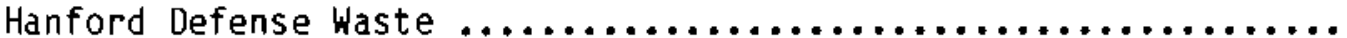

2.2 Summary of Upper-Bound Accidents and Radiation Doses Associated with the In-Place Stabilization Disposal

Alternative of Hanford Defense Waste

2.3 Summary of Upper-Bound Accidents and Radiation Doses Associated with the Reference Disposal Alternative of

2.4 Summary of Upper-Bound Accidents and Radiation Doses Associated with the No Disposal Action Alternative of Hanford Defense Waste.

4.1 Strontium and Cesium Capsule Parameters .................... 4.5

4.2 Waste Processing Steps for Geologic Disposal ............... 4.11

4.3 Waste Processing Steps for the In-Place Stabilization

4.4 Waste Processing Steps for the Reference Disposal Alternative .... 4.15

4.5 Implementation of the No Disposal Action Alternative ......... 4.16

5.1 Geologic Disposal Alternative Potential Accidential Releases for Operations Involving Six Waste Forms ................. 5.2

5.2 Postulated Airborne Releases from Accidents During Mechanical Retrieval of Single-Shell Tank Waste

5.3 Postulated Airborne Releases from Accidents During Hydraulic Retrieval of Double-Shell Tank Waste ............... 5.10

5.4 Postulated Airborne Releases from Accidents During Sludge Washing and Solid/Liquid from Separation

5.5 Postulated Airborne Releases from Accidents During

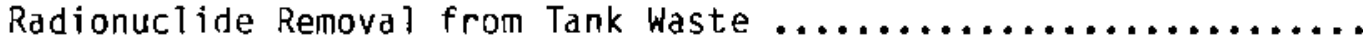

5.6 Postulated Airborne Releases from Accidents During Waste Vitrification of Tank Waste ........................ 5.20

5.7 Postulated Airborne Releases from Accidents During Grouting Decontaminated Salt Solutions 
5.8 Postulated Airborne Releases from Accidents During

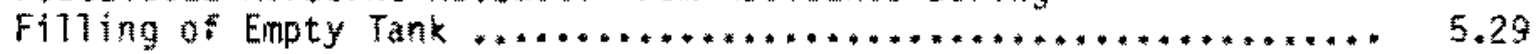

5.9 Postulated Airborne Releases from Accidents

During Capsule Recovery ...*............................ 5.33

5.10 Postulated Airborne Releases from Accidents ouring

Capsule Packaging ................................. 5.37

5.11 Postulated Airborne Releases fron Accidents During

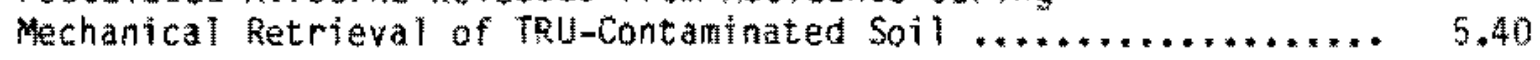

5.12 PostuTated witoorne Releases trom Accldents Ouring

3 3agging Pyrolysis Incineration of TRU-Contaninated Soil $\ldots \ldots \ldots .5 .43$

5.13 Postulated Ai rborne Releases from Accldents Juring

Mechantcal Retrieval of Pre-1970 TRu-5olid Waste ............. 5.45

5.14 Postulated Airborne Releases from Accldents During

Sorting and Related Operations with Prew1970 Solid Waste....... 5.47

5.15 Postulated Airborne Releases from Accidents During

Processing of Pre-1970 TRU Solid waste ................... 5.49

5.16 Postulated Airborne Releases from Accidents Retrieving

Remote-Hand led TRU in Caissons ........................ 5.51

5.17 Postulated Airborne Releases from Accidents During

Grouting Decontaminated Salt Solutions ................... 5.53

5.18 Postulated Airborne Releases from Accidents Ouring

Sorting and Related Operations with Contact-handled TRI ........ 5.55

6.1 In-Place Stabllization and Disposal Alternative Potential

Accidental Releases for Operations Involving Six Waste Forms ..... 6.2

6.2 Postulated Ai rborne Releases from Accidents During

in-Tank Orying of single-Shell haste $\ldots \ldots \ldots \ldots \ldots, \ldots \ldots \ldots \ldots \ldots \ldots .4 . \ldots \ldots$

6.3 Postulated Afroorne Releases from Accidents During

Done Fil1ing ....................................... 5.5

6.4 Postuated Airborne Releases fron Accident During
Hydratic Retrieval of Residual liquid $\ldots \ldots \ldots \ldots \ldots \ldots \ldots \ldots \ldots \ldots \ldots$

6.5 Postulated Atrorne Releases from Accidents During

6.6 Postulated Fractional Airborne Releases from

Accldents Buring Cestum Recovery ......................... 6.10

$x \vee i$ 
6.7 Postulated Airborne Releases from Accidents During

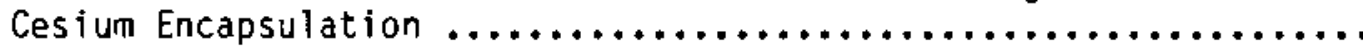

6.8 Postulated Airborne Releases from Accidents During Neutralized Current Acid Waste Grouting Operations

6.9 Postulated Airborne Releases from Accidents During

Filling of Empty Tanks

6.10 Postulated Airborne Releases from Accidents During

Retrieving Capsules

6.11 Postulated Airborne Releases from Accidents During

Capsule Packaging ...................................

6.12 Postulated Airborne Releases from Accidents During

Drywell Storage of Waste Capsule

6.13 Postulated Airborne Release from Accidents During Grout Injection

6.14 Postulated Airborne Releases from Accidents During Grout Injection of Cajssons.

6.15 Postulated Airborne Releases from Accidents During Subsidence Control ...................................

6.16 Postulated Airborne Releases from Accidents During

Subsidence Control

7.1 Reference Disposal Techniques for Six Waste Forms

7.2 Reference Alternative Potential Accidental Releases

for Operations Involving Six Waste Forms

8.1 No Disposal Action Alternative Accidental Releases for Operations Involving Six Waste Forms

9.1 Estimated Upper Bound Tank Inventory of Radionuclides

for Existing Waste

9.2 Average Concentration of Radionuclides in Grout and Glass from Existing Tank Waste

9.3a Radioisotopes Accumulated in PUREX High Level Waste from N-Reactor Production FY-1972 to FY-1990 and Decayed through FY-1995

9.3b Radioisotopes Accumulated by FY 1995 in Cladding Removal Waste from N-Reactor Production, FY 1972 through FY 1995 
9.4 Actwity in Terminal "Product" Forns from New Tanked Waste

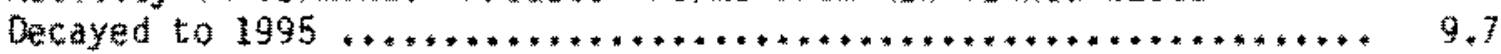

9.5 Characteristics of Existing Strontium and Cesium Capsules ........ 9.9

9.6 Assumed Strontium and Cesium Capsule and Capsule Canister

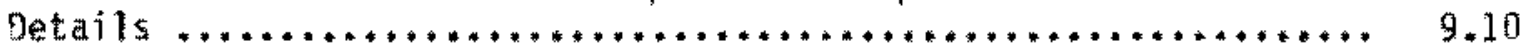

9.7 Upper-Bound TRU and Fission Product Site Inventory

Gata for TRl Contaminated Soll Sites $\ldots \ldots * * \ldots \ldots \ldots \ldots \ldots \ldots \ldots * * *$. 9.11

9.8 uper-Bound TRU Inventory site for Prem 1970 solid waste

Burtal Grounds ........................................ 9.13

9.9 Upper-Bound Fission Product Inventory Site for Pre-1970

TRU Solid Waste Burial Grounds $\ldots \ldots \ldots \ldots \ldots \ldots \ldots \ldots \ldots \ldots \ldots \ldots . . \ldots . . \ldots \ldots$

9.10 Uppermbound TRU Concentration Inventory Site for Pre-1970

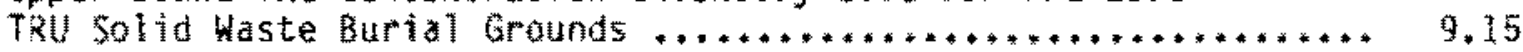

9.11 Retrievably Stored Thu Inventory $\ldots \ldots \ldots \ldots \ldots \ldots \ldots \ldots \ldots \ldots \ldots \ldots \ldots \ldots, 9.17$

10.1 Computer Programs lised to Calculate Potential Radiation

Doses from Releases During Waste Disposal Operations .......... 10.2

10.2 Population Values and Sector Averaged $X / Q^{4}$ s Used in

the Assessinent of Radiation Dose ....................... 10.4

10.3 Maximum Individual, 95 th Percentile Centerine $\bar{x} / 0^{\prime}$

values $\ldots \ldots \ldots \ldots \ldots \ldots \ldots * \ldots \ldots \ldots \ldots \ldots * \ldots \ldots \ldots * \ldots \ldots \ldots \ldots \ldots \ldots \ldots \ldots \ldots+10.5$

10.43 Geologic Disposal Alternative Potential Doses from

Acclaental Releases for Operations Involving $51 x$

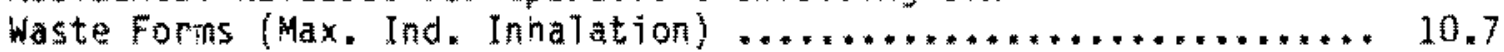

10.4b Ceologic Disposal Alternative Potential Doses from

Accidental Releases for operations Involving $5 i x$

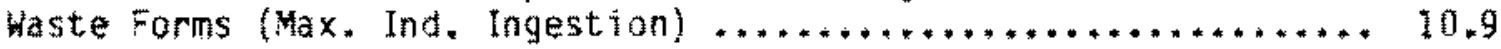

10.4c Geologic 0isposal Alternative Potential Doses from

Accidental Releases for Operations Involuing $\$$ ix

Waste Forms (Total population Dose)

10.5a In-Place Stabilization and Disposal Alternative Doses from Accidental Releases for Operations Involving $\$ 1 x$ waste Forms (Max. Ind. Inhalation) ...................... 10.14

$10.5 b$ In-Place Stabilization and Disposal Alternative Doses from Accidental Releases for Operations Involuing Six Waste

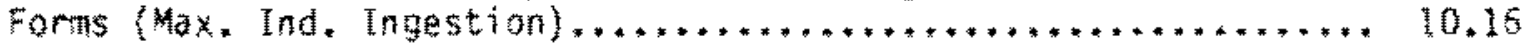


10.5c In-Place Stabilization and Disposal Alternative Doses from Accidental Releases for Operations Involving Six Waste Forms

(Total Population Dose) ............................... 10.18

10.6a Reference Alternative Potential Doses from Accidental

Releases for Operations Involving Six Waste Forms

(Max. Ind. Inhalation) ................................ 10.20

10.6b Reference Alternative Potential Doses from Accidental

Releases for Operations Involving Six Waste Forms

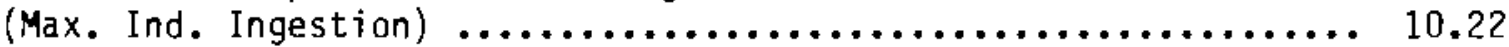

10.6c Reference Alternative Potential Doses from Accidental

Releases for Operations Involving Six Waste Forms

(Total Population Dose) .............................. 10.24

10.7a No Disposal Action Alternative Potential Doses from

Accidental Releases for Operations Involving Six Waste

Forms (Max. Ind. Inhalation) ........................ 10.28

10.7b No Disposal Action Alternative Potential Doses from

Accidental Releases for Operations Involving Six Waste

Forms (Max. Ind. Ingestion) .......................... 10.29

10.7c No Disposal Action Alternative Potential Doses from

Accidental Releases for Operations Involving Six Waste

Forms (Total Population Dose) .......................... 10.30 



\subsection{INTRODUCTION}

An important component of an environmental analysis of various waste disposal alternatives is the potential for radfological impacts on the downind population from accidents that may occur during disposal operations. Accidents in which radiological matertal is released to the atmosphere usually result in exposure of the body by means of the inhalation pathway.

Accidents of concern are those with the highest releases of radioactive particles. Known as upper-bound accidents, these can provide an umbrella saurce term for all inadvertent releases for that technique. The most severe upper-bound accidents in terms of airborne release of material are those that include danage to the factlity and or its engineered safeguards. This damage could provide a direct path for radioactive particles to enter the antent atmosphere.

Postulated accidents cover upper-bound releases. They are not antictpated; but on the basis of current knowledge of the systems and materials, they cannot be eliminated from consideration. However, some semblance of realism has been mathtained in the development of worstwcase accidents. This has been achieved by studying and evaluating the process, equipment, and confinement features of the operation.

Fractional airborne releases are calculated fom published information currently available. This includes release data calculated for sinilar accidents postulated in the literature and experimental data for similar types and levels of stresses. The fractional airborne releases are combined with the anticipated inventories of radoactive materials at the accident location and mitigation during passage through the facility to estimate an atmospheric atroome release. A standard code is then used to calculate the downind transport and resulting dose. Assumptions used for the current and future demography (population) are stated. 


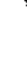

* 


\subsection{CONCLUSIONS}

Accident scenarios for three alternatives for disposal of Hanford Defense Waste are evaluated. The three alternatives are designated as the Geologic. Disposal Alternative, the In-Place Stabilization and Disposal Alternative, and

the Reference Dissposal Alternative (see Section 4.0). A "No Disposal Action" alternative is also discussed. Six types of Hanford Defense Waste are considered: existing tank waste, future tank waste, strontium and cesium capsules, transuranic (TRu) contaninated soil, pre-1970 TRUmcontaminated solid buried waste and retrievably stored and newly generated TRU waste f see section 4.01 .

The potential radiologic impacts of the various techniques funt operations) required to convert the material in each waste class into its final form for each of the disposal alternatives is one of the factors in the value-inpact evaluation used to select an altemative. In order to determine the potential radiologic impacts, the airborne release of radionuclides from potential accident or abnormal operation events during each unft operation for each waste type is required (covered in sections $5.0,6.0,7.0$, and 8.0 ). The information currently available on the proposed techniques ranges from extensive for techniques currently in use to preliminary for preconceptual descriptions. An upper-bound a irborne release is used to provide an "umbrella" term bounding all releases anticipated for the application of technlque upon waste class during an aternative. Estinates for the airborne releases are based upon scenarios for postulated actdent and abnomal operation events. Although a recurrence rate cannot be specified, almost all the events chosen are severa (if warranted by the clrcumstances) and result in the airborne release of significant quantities of radionuclides although doses to the offsite population and maximally exposed individual are low.

To convert the postulated airborne releases to dose, the radionuclides released are quantifled by using maximized inventories for the waste class involved (covered in Section 9.0), estimating the downwind transport of the released material (see Section 10.0), and evaluating the potential radiation imposed on individuals from a1! mechanisms (discussed in Section 10.0). 
A) the pertinent data for the upper-bound releases and doses are tabulated in Table 2.1 for the Ceologic Disposal Alternative, Table 2.2 for the In-Place Stabilization and Disposal Alternative, Table 2.3 for the Reference Disposal Alternative, and Table 2.4 for the No Disposal con Alternative.

The upper-bound events for the three disposal alternatives are the sane: an explosion of ferri/ferro upgrade precipitates in the salt cake during mechanlcal retrieval or microwave drying of the salt cake in single shell waste tanks, and the pressurized release of liquid waste during the hydraulic retrieval of future tank waste. The total mass of material made al rborne from an explosion is estinated to be $5 \times 10^{8} \mathrm{~g}$ of salt cake with $1.3 \times 10^{4} \mathrm{~g}$ of material in the respirable size fraction lassimed to be 10 yn or less Aerom dynanic Equivalent Diameter for this analysis). The pressurized release of waste liquid results in the airborne release of $9 \times 10^{4} \mathrm{~g}$ of material with $4.5 \times 10^{3} \mathrm{~g}$ in the size range of concern.

The calculated downwind doses to the total population and maximally exposed individual are 7000 man-rem and 3 rem (70-year dose commitment) respectively for the explosion. The corresponding values for the pressurized release event are 4000 man-rem and 2 rem, respectively. In elther case, the 1 -year dose commitment to the maximally exposed indiyidual does not exceed 0.2 rem. 
TABLE 2.1. Sumprary of Upper-Bound Accidents and Radiation Doses Associated with the Geologic Disposal Alternative of Hanford Defense Waste

Existing lonk haste

Euture Iank Wacte

Strontilus and Cesimatiz Capsules

TRtol-Conzantrated soil Stes

Prang 1970 TRI Solid 45

Retrievably Storea and Fewly fanerged Tho
Description of uper Bouten Accitent

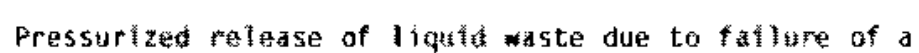
diversion value during hyaraulic retrieval at the waste.

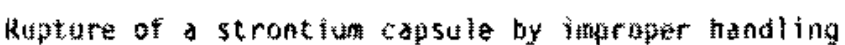
dutag retrieval dofations.

bestagracion of cotataminated materials due to process malfunction in slagging pyrolys is incinerator

Deflagratian of contaninated naterial due to pacess mal function of 5 laging pyrolysis incinerdtor:

prescarized ralease from waste druta rupture due to bullatu of radiolytus gates in the wastes. $\frac{\text { Maximuin Individual }}{\text { Total Bony bose rem }}$

i-yr pose comitment

$2 \times 10^{-1} \quad 3 \times 10^{\mathrm{B}}$

Papuldtan rotal

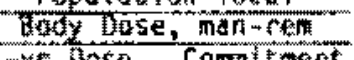

$\frac{1+y+\operatorname{cose}}{4 \times 10^{2}} \frac{\operatorname{comn}}{7 \times 10^{3}}$

$9 * 1 a^{-2} \quad 9 \times 10^{4} \quad 3 \times 10^{2} \quad \div \times 10^{3}$

$2 \times 10^{-7} \quad 3 \times 10^{-6} \quad 6 \times 10^{-4} \quad 1 \times 10^{-2}$

$5 \times 10^{-7} \quad 2 \times 10^{-5} \quad 1 \times 10^{-3} \quad 4 \times 10^{-2}$

$5 * 10^{-6} \quad 1 \times 10^{-4} \quad 1 \times 10^{-2} \quad 3 \times 10^{-1}$

$1 \times 10^{-3} \quad 3 \times 10^{-2} \quad 3 \times 10^{0} \quad 1 \times 10^{2}$ 
TABLE E.2. Sumary of Upper-bound Accidents and Radiation Doses Assoctated with the In-Place Stabllization Disposal Alternative of Hanford Defense Waste

\begin{tabular}{|c|c|c|c|c|c|}
\hline \multirow[b]{2}{*}{ Existing Tank Haste } & Deserietion of uger Bound Accident & 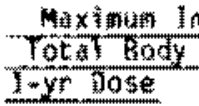 & $\frac{\text { dividual }}{\text { dose ren }}$ & \multicolumn{2}{|c|}{$\begin{array}{l}\text { Population lotal } \\
\text { gody bse nan-rean }\end{array}$} \\
\hline & $\begin{array}{l}\text { Explosich of ferrocyanide prectiotrates in the single- } \\
\text { shell tonk waste during arying of the wastes }\end{array}$ & $2 \times 10^{m+1}$ & $3 \times 10^{7}$ & $4 \times v^{2}$ & $7 \times 10^{3}$ \\
\hline Future Tanik Waste & $\begin{array}{l}\text { Pressurized release of liquid waste due to failure of a. } \\
\text { diversion valva during nydraulic retrieval of liquid } \\
\text { waste. }\end{array}$ & $9 \times 10^{42}$ & $9 \times 10^{1}$ & $3 \times 10^{2}$ & $2 \times 10^{3}$ \\
\hline$\frac{\text { Strontiug and Cesiun }}{\text { Capsules }}$ & $\begin{array}{l}\text { Shateing of strontilum capsule by improper handing during } \\
\text { disposal operations }\end{array}$ & $3 \times 10^{-44}$ & $4 \times 10^{-3}$ & $5 \times 10^{-1}$ & $1 \times 10^{1}$ \\
\hline$\frac{\text { TFil-Contaninated Soli }}{\text { Sites }}$ & 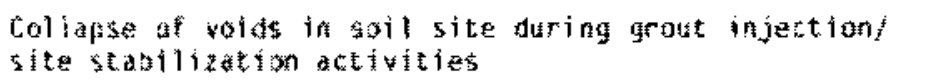 & $2 \times 11^{m 3}$ & $9 \times 10^{-7}$ & $5 \times 10^{-5}$ & $\frac{3}{2} \times 10^{-3}$ \\
\hline Pre-1970 lot solid & 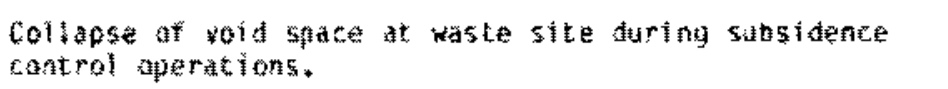 & $3 \times 33^{m}$ & $7 \times 10^{46}$ & $6 \times 10^{-4}$ & $2 \times 10^{-2}$ \\
\hline 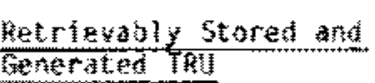 & 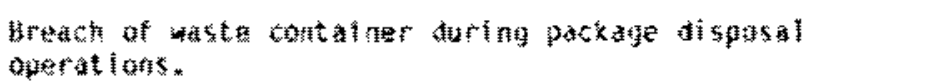 & $2 \times 1 n^{* 3}$ & $4 \times 10^{-2}$ & $5 \times 10^{0}$ & $3 \times 10^{1}$ \\
\hline
\end{tabular}


TABLE 2.3. Summary of Upper-Bound Accidents and Radiation Doses Associated with the Reference Disposal Alternat lue of Hanford Defense Waste

\begin{tabular}{|c|c|c|c|c|c|}
\hline \multirow[b]{3}{*}{ Existing Iank waste } & \multirow[b]{2}{*}{ Gescription of Upler Bound Accident } & \multicolumn{2}{|c|}{ 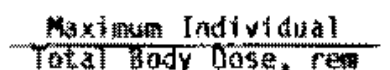 } & \multicolumn{2}{|c|}{ Population latal } \\
\hline & & $\begin{array}{l}\text { Total Bad } \\
\text { 1-yp Dose }\end{array}$ & 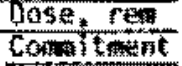 & $\frac{800 y \text { dos }}{1-y \text { tase }}$ & $\begin{array}{l}\text { manirger } \\
\text { Compaitment }\end{array}$ \\
\hline & $\begin{array}{l}\text { Explosion of ferrocyanide pracipitates la single-shell } \\
\text { tath waste durith afying of the waste }\end{array}$ & $2 \times 10^{-1}$ & $3 \times 10^{6}$ & $4 \times 10^{2}$ & $7 \times 10^{3}$ \\
\hline ruture Tank Waste & $\begin{array}{l}\text { Frassurized release of liquid waste due to fallure of a } \\
\text { diverston valve during hytraulic rearieval of the waste }\end{array}$ & $9 \times 10^{-2}$ & $9 \times 10^{-1}$ & $3 \times 10^{2}$ & $2 \times 10^{3}$ \\
\hline $\begin{array}{l}\text { Strontium and Ceslum } \\
\text { Capsutes }\end{array}$ & $\begin{array}{l}\text { Ruptur of strontium capsule by improper handling } \\
\text { during retrieval aperations }\end{array}$ & $2 \times 10^{-7}$ & $3 \times 10^{-5}$ & $6 \times 10^{-4}$ & $1 \times 10^{-2}$ \\
\hline Meu-fontani nated Sou & $\begin{array}{l}\text { Callapse of volds in the soil ste during grout injection } \\
\text { ste stabilization activities }\end{array}$ & $2 \times 10^{-3}$ & $9 \times 10^{-7}$ & $5 \times 10^{-5}$ & $2 \times 10^{-3}$ \\
\hline $\begin{array}{l}\text { Pre-1979 reu Solid } \\
\text { Yaste }\end{array}$ & $\begin{array}{l}\text { Collapse of voids in solid waste site during grout } \\
\text { injection/site stabilization }\end{array}$ & $3 * 10^{-7}$ & $7 \times 10^{-6}$ & $6 \times 10^{-4}$ & $2 \times 10^{-2}$ \\
\hline 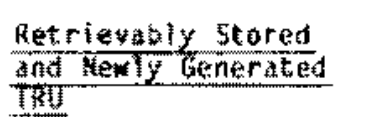 & 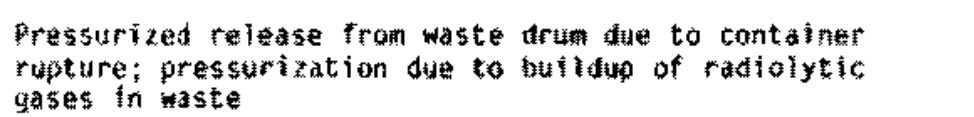 & $2 \times 10^{-3}$ & $6 \times 10^{-2}$ & $4 \times 10^{0}$ & $1 \times 10^{2}$ \\
\hline
\end{tabular}


TABLE 2.4. Summary of Upper-Bound Accidents and Radiation Doses Associated with the No Disposal Action Alternative of Hanford Defense Waste

\begin{tabular}{|c|c|c|c|c|c|}
\hline & Description of Upper Bound Accident & $\frac{\text { Maximum I }}{\text { Total Body }}$ & $\frac{\text { ndividual }}{\text { Dose, rem }}$ & $\frac{\text { Populati }}{\text { Body Dose }}$ & $\frac{\text { on Total }}{\text { - man-rem }}$ \\
\hline Existing Tank Waste & $\begin{array}{l}\text { Pressurized release of liquid waste due to failure of a } \\
\text { diversion valve during hydraulic retrieval of the waste }\end{array}$ & $6 \times 10^{-2}$ & $9 \times 10^{-1}$ & $1 \times 10^{2}$ & $2 \times 10^{3}$ \\
\hline Future Tank Waste & $\begin{array}{l}\text { Pressurized release of liquid waste due to failure af a } \\
\text { diversion valve during hydraulic retrieval af the waste }\end{array}$ & $9 \times 10^{-2}$ & $9 \times 10^{-1}$ & $3 \times 10^{2}$ & $2 \times 10^{3}$ \\
\hline$\frac{\text { Strontium and Cesium }}{\text { Capsules }}$ & $\begin{array}{l}\text { Rupture of strontium capsule by improper handling } \\
\text { during retrieval operations }\end{array}$ & $2 \times 10^{-7}$ & $3 \times 10^{-6}$ & $6 \times 10^{-4}$ & $1 \times 10^{-2}$ \\
\hline TRU-Cont aminated Soil & $\begin{array}{l}\text { Collapse of voids in the soil site during site } \\
\text { stabilization activities }\end{array}$ & $2 \times 10^{-8}$ & $9 \times 10^{-7}$ & $5 \times 10^{-5}$ & $2 \times 10^{-3}$ \\
\hline $\begin{array}{l}\text { Pre-1970 TRU Solid } \\
\text { Waste }\end{array}$ & $\begin{array}{l}\text { Collapse of voids in solid waste site during site } \\
\text { stabilization }\end{array}$ & $3 \times 10^{-7}$ & $7 \times 10^{-6}$ & $6 \times 10^{-4}$ & $2 \times 10^{-2}$ \\
\hline$\frac{\text { Retrievably Stored }}{\text { and Newly Generated }}$ & $\begin{array}{l}\text { Collapse of void space at waste site during } \\
\text { site-stabilization activities }\end{array}$ & $5 \times 10^{-6}$ & $6 \times 10^{-5}$ & $1 \times 10^{-2}$ & $2 \times 10^{-1}$ \\
\hline
\end{tabular}




\subsection{TECHNICAL APPROACH AND METHODS}

\subsection{TECHNICAL APPROACH}

The potential radiological impacts of the proposed waste handling and processing techniques covered in this study are the doses to humans from the airborne release of radionuclides by postulated severe accidents and abnormal operations. This report assumes that the most significant hazard (inhalation, skin dose, immersion dose) results from the sudden airborne release of radionuclides. In order for the airborne release of material to be estimated, the level of force exerted by the event, the physical and chemical form of the radionuclides involved, the mechanism that deagglomerates or subdivides and disperses the radionuclide, the degree to which the released material is contained and deposited prior to release to the environs must all be considered.

Accidents are defined as credible situations which create demand upon the system beyond the capability of the process, equipment, or containment features. Because of the conservative nature of the study approach, mitigation by standby or engineered safety features is not considered. 'Credible,' in this case, signifies situations which cannot be eliminated by the design of existing systems and processes or laws of physics or chemistry under the stated conditions. Abnormal operations are defined as events resulting from malfunctions of the systems, improper operating conditions or operator errors. It is not necessary for this study to classify the events covered into these categories (clear separations may not always be possible); the important fact is to estimate the airborne releases from such events.

The estimate of the conditions generated and the quantity of radionuclides airborne are based upon scenarios (sequences of events and their consequences). Scenarios were chosen from accidents and abnormal operations that have occurred in waste handling/processing facilities used in the past or from reports of the consequences of potential accidents and abnormal events for proposed similar waste operations (Hayward and Jensen 1980, DOE 1982, Murphy and Holter 1980 , Richardson 1980). 
A conservative approach (i.e., one that is belleved to overstate rather than understate the consequences) is used to estimate the potential airborne releases.

The quantity of radioactivity released wh the airborne materials is estimated using the radionuclide inventories associated with the specific waste form involved in the operations covered. The reference radionuclide inventories for the waste classes were reported by Rockwell Manford Operations (Rockwell 1985). Upper-bound reference radionuclide inventories used to assess the potential radiological impacts are based upon estimates of the most significant inventories (the largest quantity or highest concentration) which could be present or actual measurements avallable of these values.

Potential downwind transport and dose were evaluated using established Hanford transport and dose models tsection 9.0$)$.

\subsection{KEY ASSUMPTIONS}

The following ky assumptions were made for this analysis:

1. All facilities, processes, and operations are or will be designed, constructed, and used in a manner consistent wth prudent and proven practices.

2. The processes, facilities, operations, radionuclide inventories, and waste forms are those described in the englneering support data (Rockwell 1985 ).

3. The upper-bound accldent identified as having the greatest potential radiological consequences for given operation is assumed to conservatively bound (upper limit) all other credible accldents that could occur during that particular operation.

\subsection{METHOOS}

A great deal of information is required to make a precise estinate of the potential airborne release of radionuclides from an event. Some, but not necessarily all, types of information requiped are: description of the process and equipment involved, including flows, capacities, and auxiltary systems; the 
characteristics of the materials involved (both the material being processed and the materials used in the process); the physical configuration and cond $i-$ tions under which the material is processed (cell and building characteristics and capabilities, building and cell systems such as off-gas and ventilation); the services and power used and the purpose for which they are used; control systems and the consequences of loss of control; the reliability of the equipment, process, and facility; the behavior of all materials involved to various levels of stress imposed (e.g., heat, pressure, and shock); and the types and levels of stresses that could make the material of concern airborne and compromise the integrity of all containment barriers.

The various techniques under consideration to process the six waste types into a final disposal form range from those currently in use to those in the preconceptual stage. The quantity of information available ranges accordingly. Thus, neither the amount of information nor the time available allows rigorous adherence to the outline given above for the assessment of the potential consequences from accidents and abnormal operations. The approach taken in this study was to search for published reports describing similar operations and to use the information of the consequences presented. When such information was available, the values given were used without further evaluation. In some instances, scenarios describing the postulated events were not given, and the applicability of the information to the operations covered in this report could not be evaluated.

Other events not covered in published reports were also included as they were suggested to the authors based on their experience in consequence assessment. If information on the consequences was not in the published literature available to the authors, assessment was made using their knowledge of the situations and experimental data on the airborne release of material under similar levels of stress. When analysis indicated that no significant quantity of radionuclides was released as a consequence of an event, that fact was so stated. Finally, when an estimate of the airborne release could not be made due to the lack of information, a method of evaluating the situation was outlined. 
The scenarios selected for estimating the potential upper-bound radiological inpact by a given operation tend to be thase which result in large energy releases and involve radionutides in a disperstule form. This is not surprising since energy is required to subdivide and disperse or to deagglomerate and disperse the radionuclides and also to compromise the integrity of the containment and barriers which normally prevent the entry of radionuclides into the environs. Events with potential for large energy releases, such as flres and explosions, are prime candidates. The level and type of stress over given time period determines which materials will react in what way, what barriers/ containment may survive, and which engineered safety features can function. Such mitigating features are considered where possible. The containment feature nost susceptible to danage from energetic events is the highufficiency particulate air filters, which usually are the last barrier to relase to the atmosphere and are relatively fraghle. They are also often a great distance from the source of energy and protected by engineered safety features to prevent damage.) operations involung uncontained, subdivided radioactive materials (f.e*, powders) or performed outdoors with no containment were al so prime candidates for upper-bound events. 


\subsection{WASTE FORMS AND DISPOSAL ALTERNATIVES}

The study focused on the potential upper-bound radiological impacts of operational accidents during the operations proposed for three possible disposal alternatives performed on six waste forms. The six waste forms and three disposal alternatives are described in this section. A baseline case, continued storage, which consists of monitoring and maintaining the current waste storage sites without taking any disposal actions (sites are not stabilized, barrier and marker system is not installed, etc.) is also addressed.

\subsection{WASTE FORMS}

There are six waste forms: existing tank waste, future tank waste, strontium and cesium capsules, TRU-contaminated soil, pre-1970 solid waste, and retrievably stored and newly generated TRU solid waste. They are described in the Rockwell engineering packages (Rockwell 1985). Most of the forms are described as of January 1984 except those which do not currently exist, e.g., future tank waste, newly generated TRU solid waste.

\subsubsection{Existing Tank Waste}

Four major classes of waste are contained in existing tank waste:

1) sludge produced from components of high-level waste that precipitate when the waste is neutralized

2) salt cake produced when waste supernatant liquids are concentrated beyond the solubility limit of a major component

3) double-shell slurry (the supernatant liquid after salt cake formation)

4) complex concentrate produced by concentration of waste containing large amounts of organic complexing agents. 
The first two classes of waste are stored prinarily in the older (singlemshell) tanks; the latter two in the newer (double-shell) tanks. Some supernatant liquid, contained in the older tanks, is being transferred as completely as posstble to new tanks. The volumes and compositions of waste in individuat tanks vary considerably, depending on the source of the waste and on past waste management practices at the respective tank farms. The processing schemes proposed to disposa of the type of waste depend upon the storage mode, radionuclide content, thermal release due to radioactive decay, and the chemical and physical form of the waste (ease of retrieval and processing).

\subsubsection{Future Tank Waste}

Future tank waste includes PUREX plant waste generated during the current operations, wich began in November 1983, together with liquid wastes from other sources lincluding liquid waste projected for the operations of the Plutontum Finishing Plant) projected through 1955. All these wastes are stared in doublemell tanks. The sources and composition of future tank waste are described below.

\subsubsection{Neutralized Current Acid Waste}

Wigh-level wastes from PlWEX operations will be natralized and stored. The neutralized current acid waste would be separated into two phases: 1) a solid phase (a suspended sludge of insoluble materials) primarly conststing of hydroxides or hydrated oxides insoluble in the highly alkaline aqueous solution, and 2) a supernatant liquid consistang of an aqueous solution of sodium nitrate (resulting from the neutralization of the nitric acid by sodium hydroxide), sodium nitrite (resulting from the radiolytic reduction of the sodiun nitrate), sodium sulfate (resulting from the conversion of sulfarate to sulfate) sodium aluminate (resulting from the aluninun additions to camplex fluoride lons, and sodiun hydroxide.

The sludge would contain most of the fission products lexcept cestum and technetium) and unrecovered TRU. The supernatant liquid contains most of the

cesfum and technetium, the fodine not removed in the head-end process or decayed, and some of the ruthenium. The two-phase slurry cannot be economically vitrified since the sulfate linits the quantity of waste that can be 
incorporated into the borosilicate glass. The sludge is separated from the supernate and washed free of sulfate (and also the soluble aluminate), minimizing the quantity of glass generated.

\subsubsection{Cladding Removal Waste}

The zircaloy cladding on N-Reactor fuels is dissolved chemically in the PUREX plant by reaction with an aqueous ammonium fluoride solution containing ammonium nitrate to suppress the evolution of hydrogen. The dissolvent slowly attacks the uranium metal as it becomes exposed after cladding removal. Solids and liquid are separated by centrifugation. A portion of the resulting uranjum fluoride (with the actinide and fission product associated with it) not removed by centrifugation remains with the waste. Neutralization removes essentially all the TRU and fission products from solution. The supernatant liquid is thus non-TRU, low-level waste.

\subsubsection{Organic Wash Waste}

As part of the PUREX process, the organic solvent is washed to remove degraded organics that could otherwise interfere with the process. The wash solution contains sodium carbonate and potassium permanganate. Trace quantities of metal ions are removed from the organic solvent by this washing. As the aqueous wash becomes ineffective, the depleted aqueous wash solutions are combined with cladding removal waste for storage in double-shell tanks.

\subsubsection{Plutonium Finishing Plant Waste Composite}

Plutonium finishing plant waste composite is assumed to be a blend of waste from Z-plant (PUREX product metal reduction plus ash and oxide scrap recovery), S Area laboratory waste, and T-Plant waste. This excludes any special waste streams resulting from isotope separation efforts.

\subsubsection{Miscellaneous Wastes}

A variety of low-level wastes are included in this category. Some are additional wastes arising from PUREX operations, such as ammonia scrubber wastes, miscellaneous sump waste, and low-level waste from the latter portions of the process. Others are low-level wastes from operations elsewhere in the 
200 Area (B-Plant, T-plant, etc.). The scrubber and sump wastes are conbined with the cladding removal waste, and the 200 -Area wastes with the low-level wastes from the latter portions of the PUREX operations.

Other low-level wastes are generated by operations in other areas of Hanford. These and the low-level 200-Area wastes contain low concentrations of chemtcals and radionuclides with large volumes. These two groups of low-level liquid waste will be concentrated by a factor of ten, and, when concentrated, nay be classlfied as TRU waste.

\subsubsection{Strontium and Cesium capsules}

Most of the high-heat generating fission products, ${ }^{90} \mathrm{Sr}$ and ${ }^{137} \mathrm{Cs}$, have been extracted from the high-level waste and encapsulated in seal-welded, highintegrity doublewall metal capsules (see figure 4.1 ) as strontium fluoride and cestun chloride. Capsule parameters are listed in Table 4.1. The capsules are currently stored in shielded watermflled basins for dissipation of decay heat and reduction of exposure to operating personnel. This method of storage provides multiple containment of the radionucijdes by the double-wall capsules. water basin, reinforced concrete building, and a directional air system providing filtration by multiple stages of high-efficiency particulate a ir ilters. In the event of a capsule fallure, the damaged capsule can be returned to the process cell, re-encapsulated, and returned to the water basin. Contaminated water can be processed to remove the radionuclites and returned to service. Storage of the strontium and cesium capsules will continue in the existing water basins until a disposal or long-term storage alternative is selected.

\subsubsection{TRU-Contaminated So 11}

This waste form is primarly composed of systems formerly used to discharge TRUm-contaminated liquids to hanford solls and some incidental stus contaninated by other means. The types of systems used to discharge TRUcontaninated liquids include:

- cribs - suried structures (aften wood or concrete) filled with aggregate that holds or disperses liquids and/or solutions for percolation into the ground 


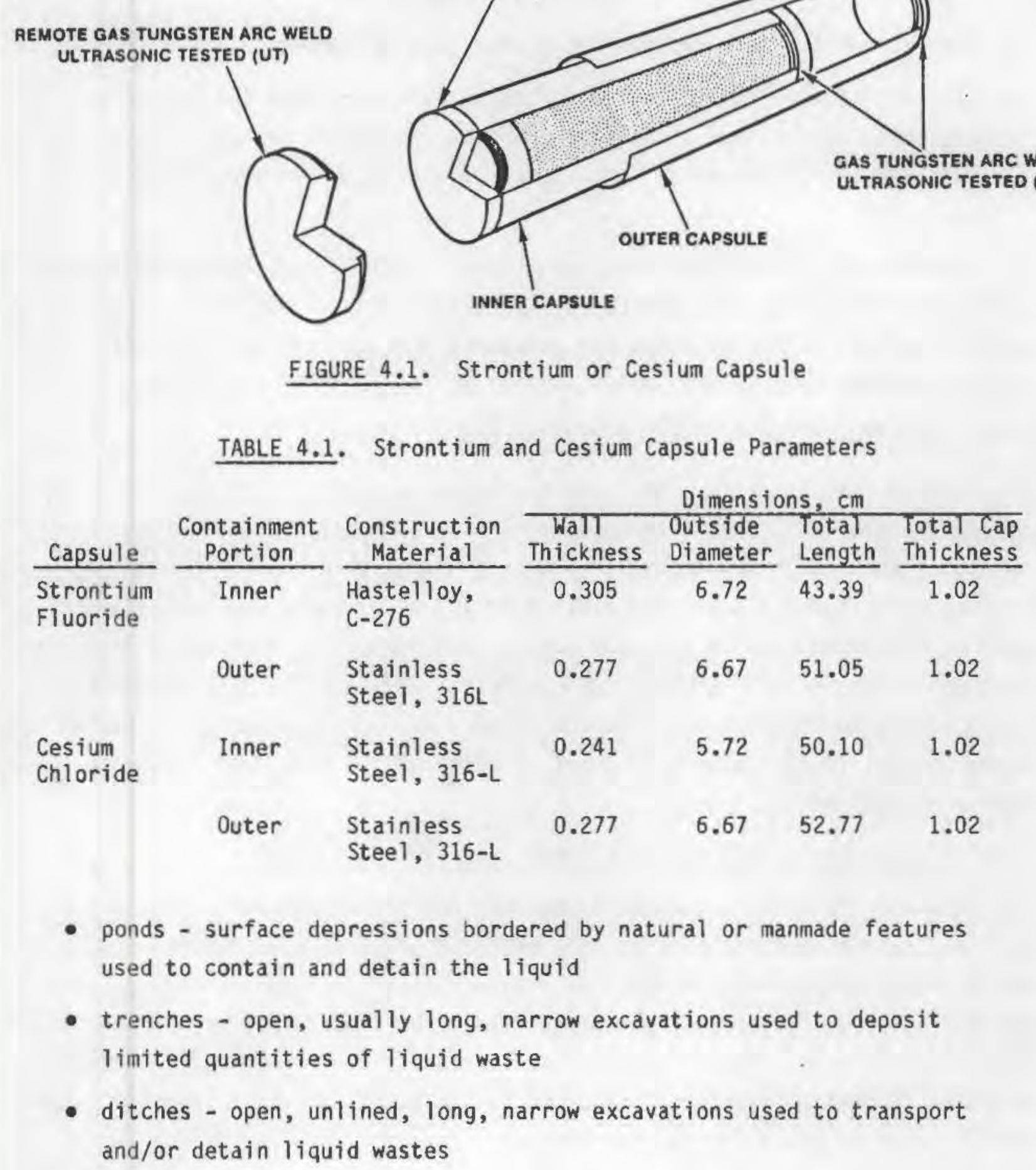


- French drains - large-diameter pipes buried vertically, normally less than $14 \mathrm{~m}$ deep, filled with rocks to allow the percolation of small, intermittent flows of liquid waste into the soil

- reverse wells - well casings going deep into the ground

- settling tanks - single-wall underground tanks or sumps made of concrete into which liquid waste is pumped. The solids settle in the tank and liquids overflow into a reverse well or other underground structure.

Movement of radionuclides into and through soil varies considerably and depends upon soil chemistry (Murthy et a1. 1983). In the absence of complexing agents, the bulk of TRU elements and compounds move through the soil only slightly and are held (within a few meters) of the point of discharge.

4.1.5 Pre-1970 TRU Solid Waste Burial Ground

Between 1944 and 1970, TRU-contaminated waste (soiled clothing, laboratory supplies, tools, etc. packed in cardboard, wood or metal containers) was buried in "alpha" trenches. An "alpha" trench is an excavation in the ground 5 to $8 \mathrm{~m}$ deep with sloped sides and a minimum of $1.3 \mathrm{~m}$ of overburden (normally the depth of the overburden is 3 to $6 \mathrm{~m}$ deep). A schematic of such an arrangement is shown in Figure 4.2. A burial ground is defined as a TRU solid waste burial ground if the concentration of some containers at that location is estimated to exceed $100 \mathrm{nCi} \mathrm{TRU} / \mathrm{g}$ (based upon a soil density of $1.8 \mathrm{~g} / \mathrm{cm}^{3}$ and a peak-toaverage concentration of $10: 1$ ).

\subsubsection{Retrievably Stored and Newly Generated TRU Solid Waste}

TRU waste generated since 1970 has been retrievably stored. If the surface dose rate exceeded $200 \mathrm{mR} / \mathrm{hr}$, the waste is classified as remote-handled and is either stored in caissons (see Figure 4.3) or packaged for direct shipment offsite. If the TRU waste was unsuitable for asphalt pad or caisson storage because of size, chemical composition, security requirements, or surface radiation, it was packaged in reinforced wooden boxes, concrete or metal boxes and stored in an alpha trench (see Section 4.1.5). 


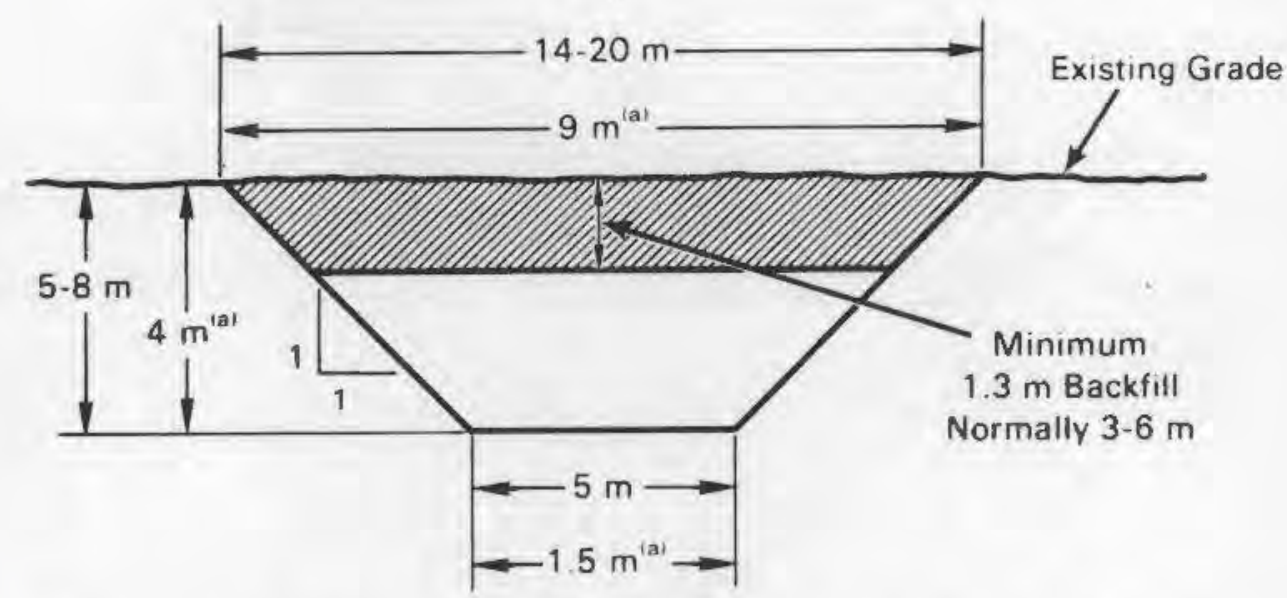

(a) Dimensions for Typical "Dry Waste" Trench; Cardboard Boxes, Barrels, etc. (Larger Dimensions are for Contaminated "Industrial" Solid Waste Trench; Failed Process Equipment in Large Metal or Concrete Boxes).

FIGURE 4.2. Typical Solid Waste Burial Trench

TRU asphalt pad storage is shown schematically in Figure 4.4. Most of the waste is packaged in 55-gal metal drums. The containers are covered with plywood, plastic-reinforced nylon sheeting, and a 1.2-m layer of uncontaminated soil to reduce surface radiation exposures to less than $1 \mathrm{mR} / \mathrm{hr}$. Ventilation is provided to reduce humidity and resultant rusting of the drums.

Newly generated TRU waste in approved packaging maybe be temporarily stored on pads with appropriate coverings.

\subsection{DISPOSAL ALTERNATIVES}

Three processing schemes or disposal alternatives to permanently dispose of the Hanford Defense Waste are under consideration. The three alternatives are labelled 'geologic disposal alternative', 'in-place stabilization and disposal alternative,' and 'reference alternative.' Basically, the geologic disposal alternative places most of the waste in a deep geologic repository (only the clearly low-level waste is grouted). The in-place stabilization and disposal alternative leaves most of the waste at its current sites, isolated from the ecosystems, but the high-level waste in the double-shell tanks is processed 


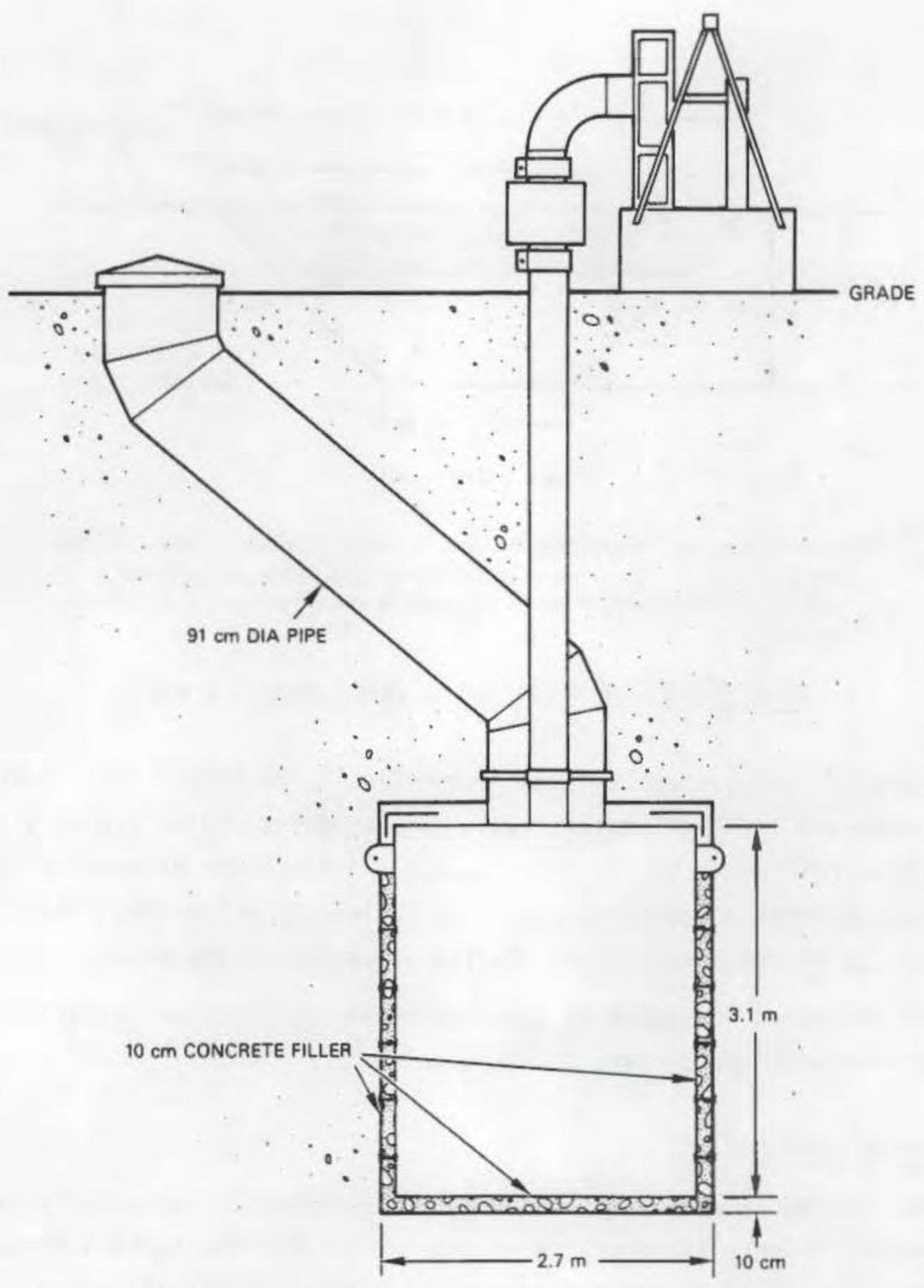

FIGURE 4.3. Caisson for TRU Storage 


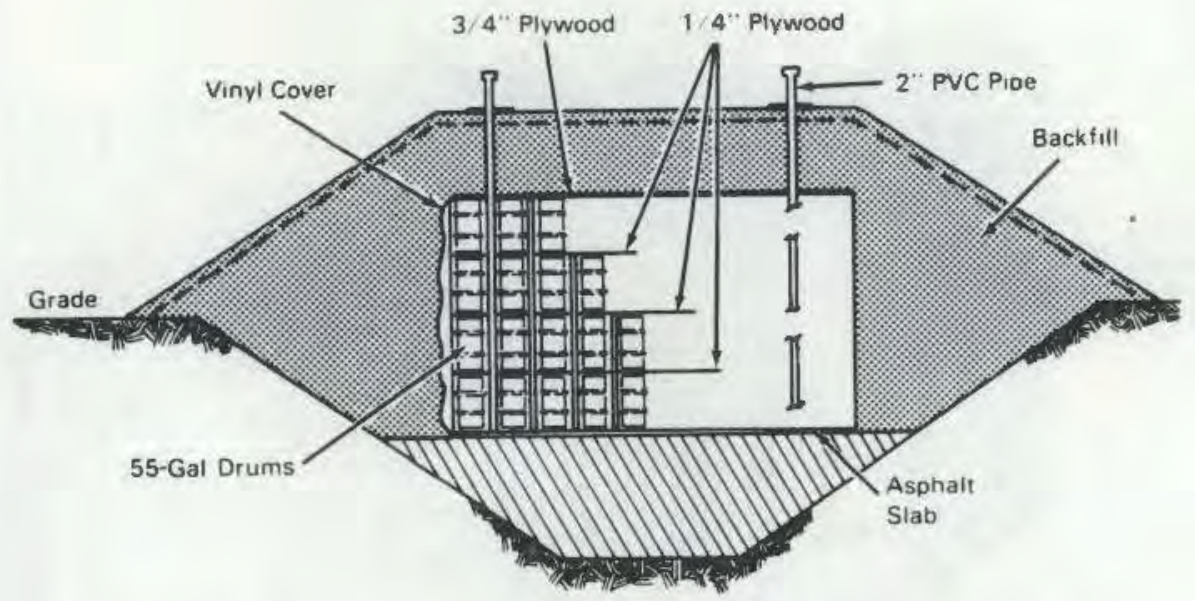

FIGURE 4.4. TRU Asphalt Pad Storage (ERDA 1975)

to remove the high-heat-generating radionuclides. In the reference alternative, the operations are chosen to be performed on the waste forms to balance the near- and long-term risks from processing or leaving the material in place. The three disposal alternatives are discussed in greater detail below.

\subsubsection{Geologic Disposal Alternative}

This alternative involves the retrieval, processing, segregation, packaging and placement of most waste in a deep geologic repository with some nearsurface disposal. The location of the repository and its function, i.e. whether dedicated to defense waste or co-mingled with commercial wastes, are not known at this time but are unimportant for this analysis. A conceptual deep geologic repository is shown in Figure 4.5 .

Under this alternative, some of the waste (e.g., existing tank waste described earlier in this section) is divided into high-level and low-level fractions. The high-activity, low-volume fraction is vitrified as borosilicate glass, packaged and deposited in a deep geologic repository. The larger lowactivity fraction is made into a suitable cement (grout) and near-surface disposal is used. A schematic illustrating the various operations proposed for the six waste forms in this alternative is shown in Table 4.2 . 


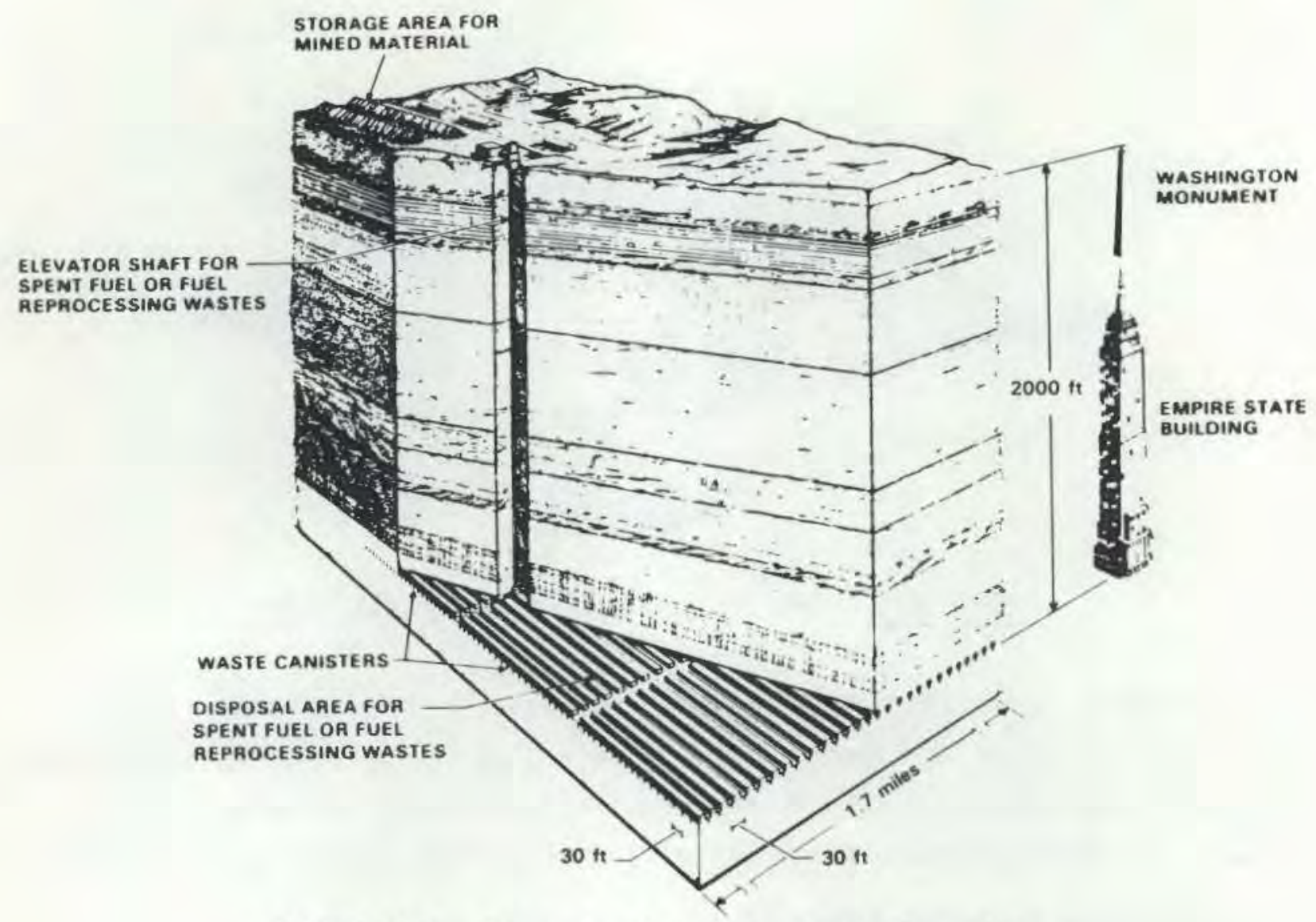

FIGURE 4.5. Conceptual Deep Geologic Repository

\subsubsection{In-Place Stabilization and Disposal Alternative}

The concept of in-place stabilization and disposal is to stabilize inplace all high-level and TRU waste at Hanford using a protective barrier and marker system to isolate the disposed materials from all ecosystems. An application of the barrier and marker system applied to one waste type, singleshell tank waste, is illustrated in Figure 4.6.

Very little processing is envisioned in this alternative except for the waste stored in double-shell tanks. Removal of the high-heat-generating radionuclides (i.e., cesium) to permit formulation of a suitable grout may be required. The cesium removed is encapsulated and handled in the same manner as the existing encapsulated materials (near-surface Drywell Storage Facility). Waste in the single-shell tanks would be dried, and interim heat removal systems would be provided as needed. Waste in all TRU sites (soil, pre-1970 


\section{TABLE 4.2. Waste Processing Steps for Geologic Disposal}

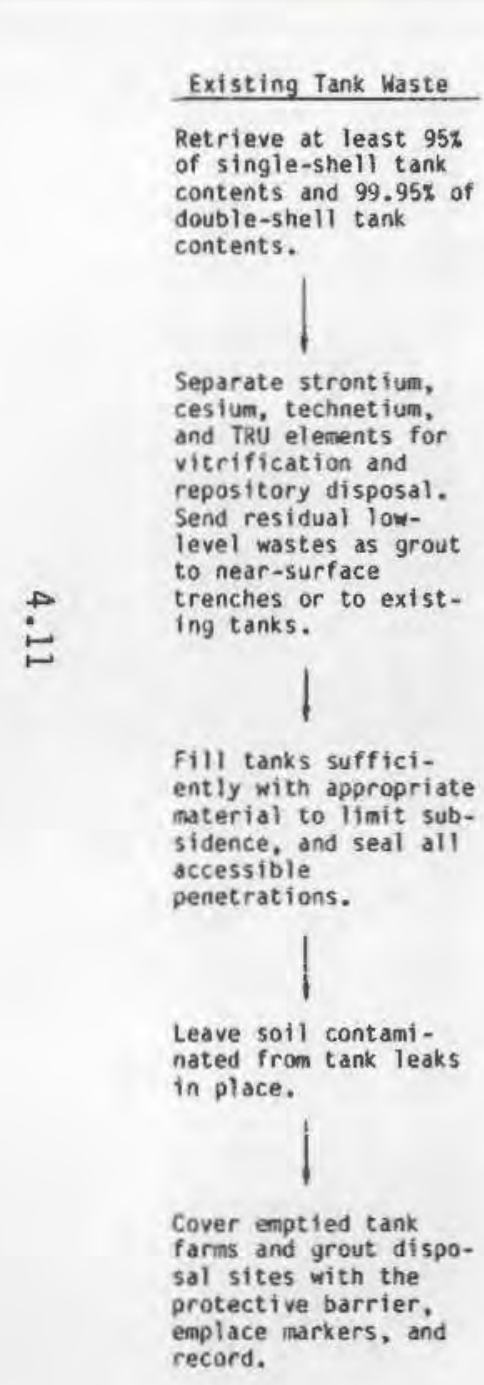

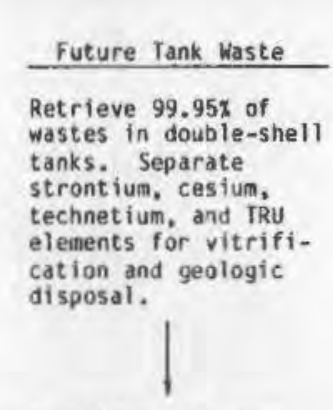

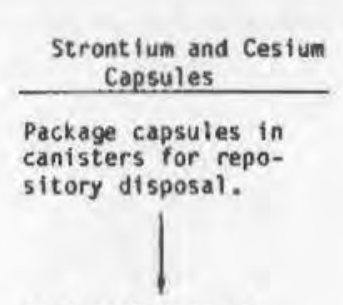
Send canisters to
geologic repository

Imobilize the resi-

dual waste as grout

near-surface trenches

or in existing tanks.

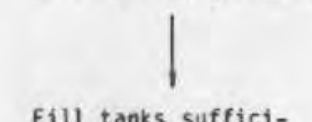

Fill tanks suffici-

ently with appropriate

subsidence, and seat

all accessiole.

penetrations.

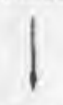

Cover grout disposal waste sites and tanks with the protective

barrier, emplace

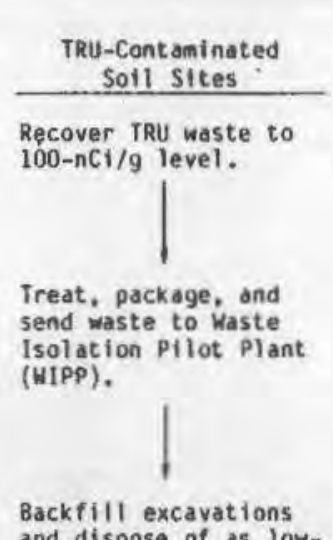

and dispose of as low level waste sites.

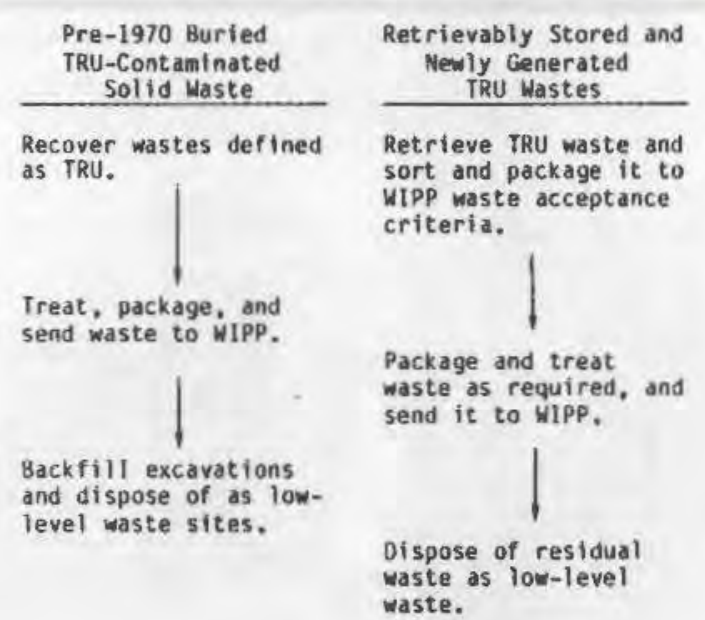

Netrievably Stored and
Generated

Retrieve IRU waste and ort and package it to

waste. 
Warning Markers Around Periphery of Waste Disposal Site
Fine Soil and Basalt Riprap Mix

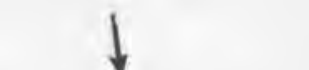

Revegetated

$1.5 \mathrm{~m}$ of

$0.3 \mathrm{~m}$ of Rock/ Gravel Filter with

$3.6 \mathrm{~m}$ of Basalt Geotextile Fine Soil

Surface
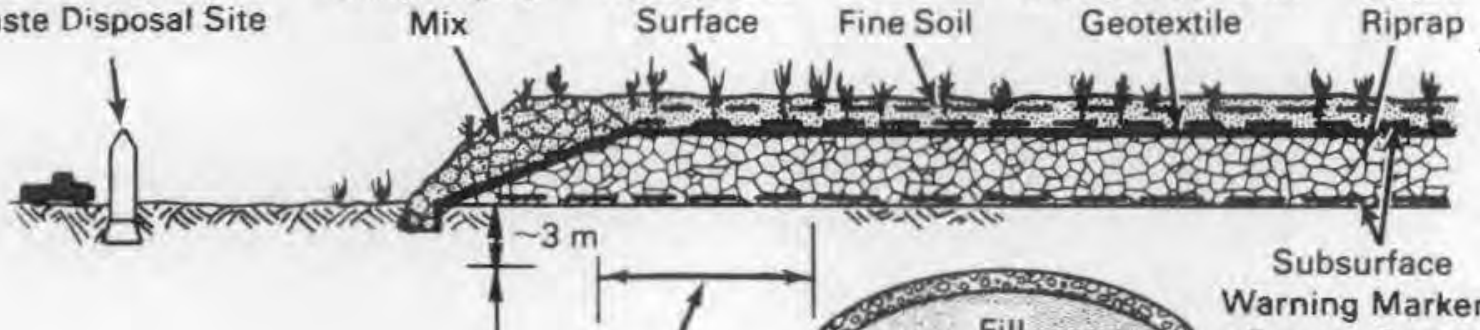
$\sim 8 \mathrm{~m}$ $+$

Up To

Fill $3 \mathrm{~m}$ on Center

Unconsolidated and Unsaturated Sediments

43 to $70 \mathrm{~m}$

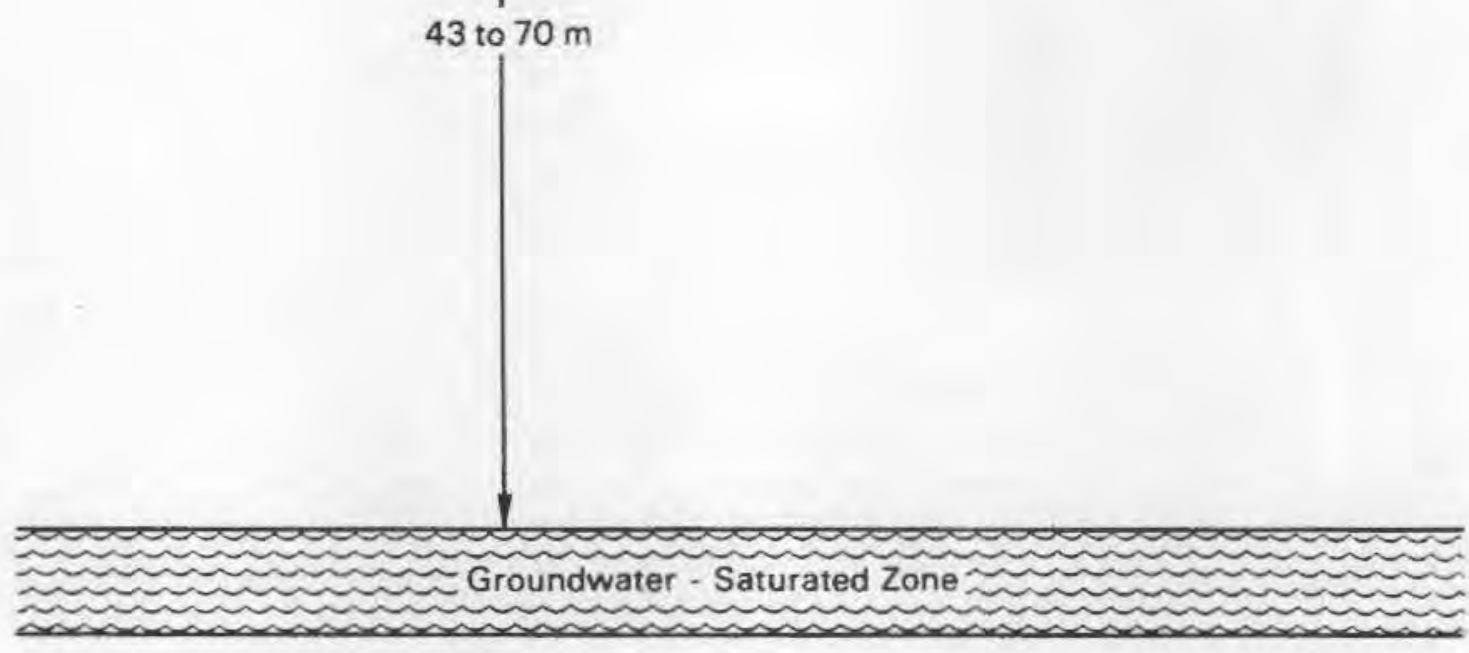

FIGURE 4.6. Schematic of Protective Barrier as Applied to Single-She1l Tank Waste 
solid waste sites, and sites with retrievably stored or newly generated waste) would not be relocated but interred in place. All sites would be treated for subsidence control as needed and covered with a protective barrier and marker system. Although in-place stabilization would be considered permanent disposal, it does not preclude future generations from removing the waste. The operations proposed for the six waste forms for this alternative are shown schematically in Table 4.3 .

\subsubsection{Reference Alternative}

The concept directing the reference alternative is to provide a balanced approach that would give a reasonable expectation that the long-term risks are limited without incurring unacceptable near-term risks (disturbing currently stable and/or difficult-to-retrieve waste sites). In a sense, this alternative is a combination of the two previously described alternatives, choosing the optimal processing scheme for each waste class. Geologic disposal would be used for the strontium and cesium capsules, for the high-activity portions of existing double-shell tank and newly generated tank wastes, and for most retrievably stored and newly generated TRU waste. Other waste that is not readily retrieved and for which the short-term environmental risks may outweigh the benefits of deep geologic disposal would be disposed of by in-place stabilization. The operations proposed for this alternative on the six waste forms are shown schematically in Table 4.4 .

\subsubsection{No Disposal Alternative}

A no disposal action alternative, which amounts to continued storage of the wastes, was also considered in detail. In the short term (i.e., for periods less than 100 years), the no disposal action alternative can be considered as a "delay major action" alternative, after which time disposal a)ternatives could be considered. If DOE chooses the no disposal action alternative, waste would remain as disposed of or continue to be stored indefinitely using existing storage practices with planned improvements. The operations proposed for this alternative are shown in Table 4.5. Active 
TABLE 4.3. Waste Processing Steps for the In-Place Stabilization Alternative

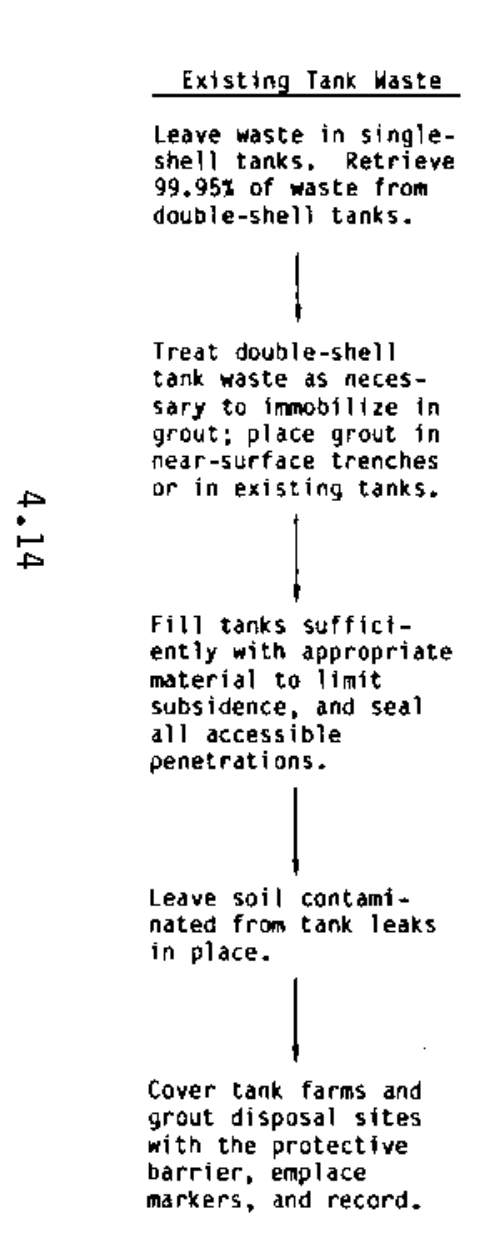

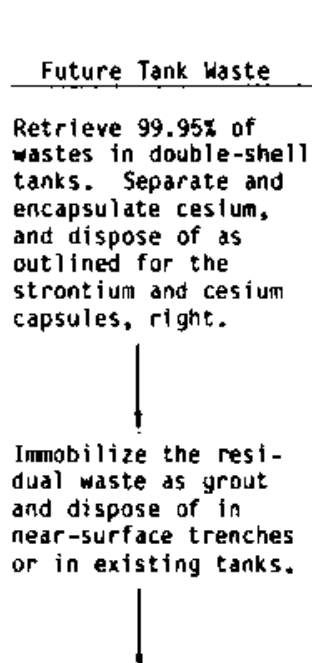

Fill tanks suffici-

ently with approprlate material to $1 i_{\mathrm{mi}}$ subsidence, and seal all accessible penetrations.

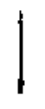

Cover grout disposal waste sites and tanks ith the protective markers, and record.

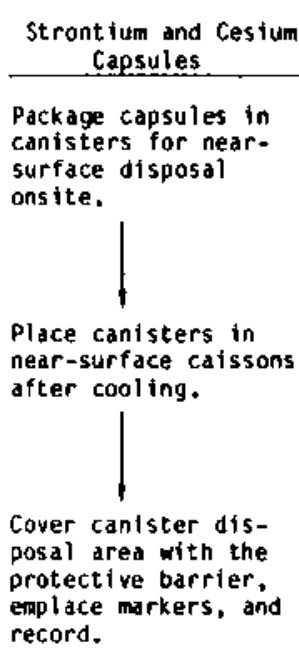

Place canisters in near-surface caissons after cooling.

Cover canister disposal area with the protective barrier. emplace markers, and record.

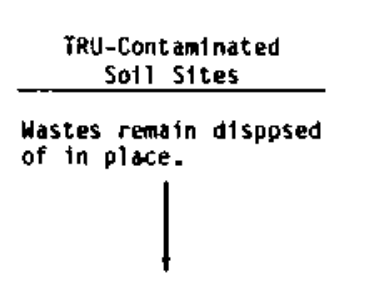

Fill voids with grout to limit subsidence.

Cover all sites with
the protective
barrier, enplace

markers, and record.

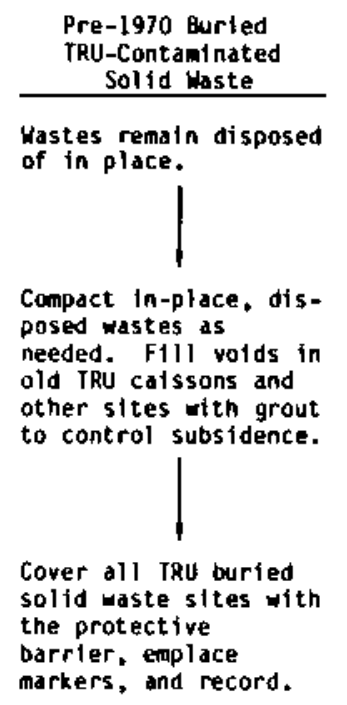

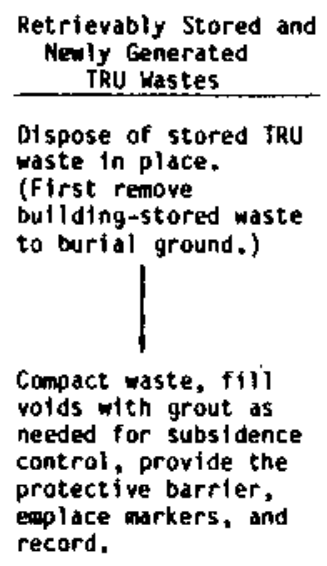

ispose of stored $\mathrm{ZRU}$ waste in place. (First remove.

bullding-stored waste to burial ground.) 1

Compact waste, fill volds with grout as needed for subsidence control, provide the protective bartler. emplace markers, and record. 
TABLE 4.4. Waste Processing Steps for the Reference Disposal Alternative

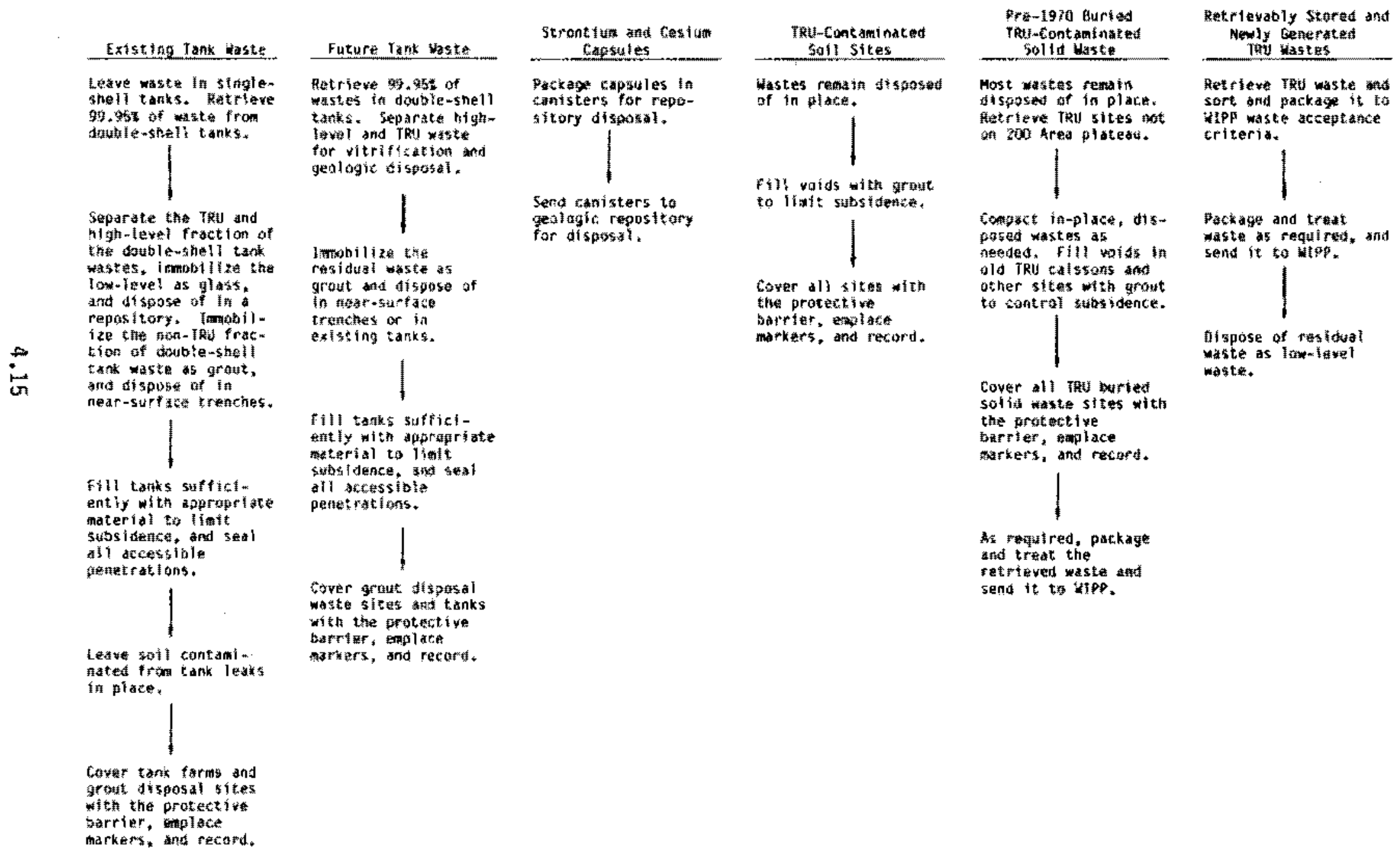


TABLE 4.5. Implementation of the No Disposal Action Alternative

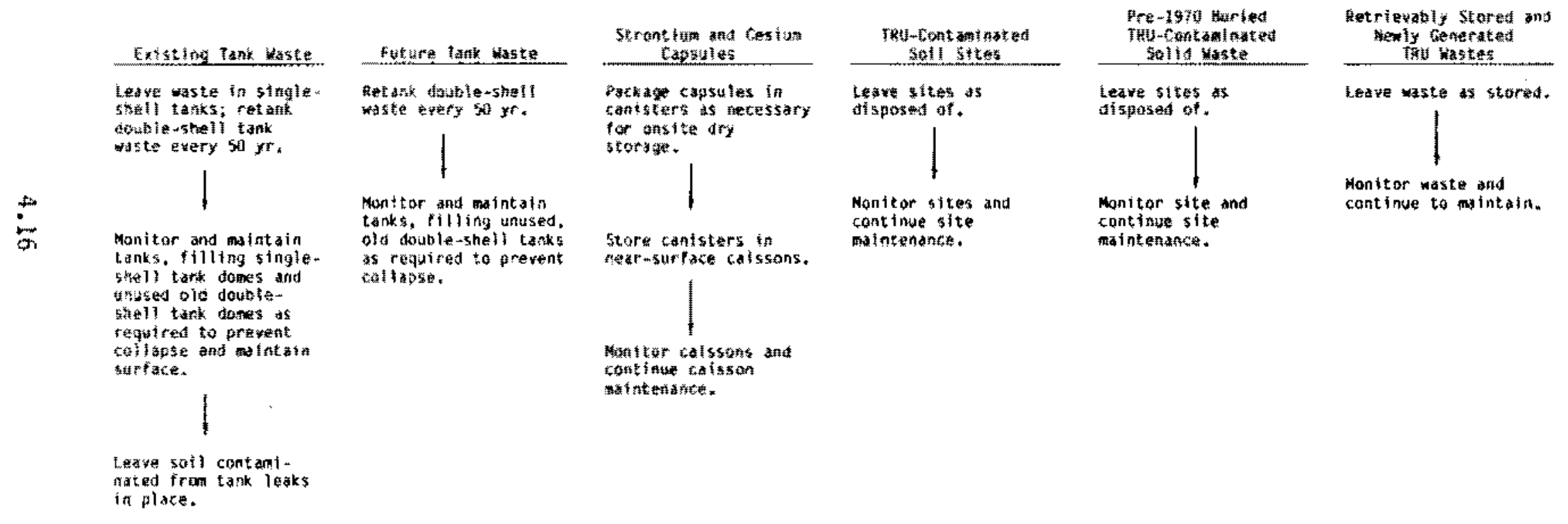


admintstrative control would be provided. Federal ownership and presence on the Hanford site is planned in perpetuity, but for comparative analyses loss of active institutional control is assumed to occur fn the year 2150. It must be emphasized that this scenario was defined simply for comparing alternatives. 
,

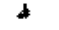
. 


\subsection{POSTULATED RELEASES FROM POTENTIAL ACCLIOENTS ASSOCIATED WITH THE GEOLOGIC OISPOSAL OF SIX WASTE FORMS}

Several operations are required to process each of the six waste forms for geologic disposal. This section contains a brief description of each waste processing operation used and the factitity involved. Uppermbound release is then estimated, and other potential accidents are discussed. The capability of the facility in which an operation is presumed to occur and the transport/ mitigation before the release of the airborne material to the environent are also included. Upper-bound releases are listed in Tables 5.1,6.1, 7.2 , and 8.1 for the geologic, in-place stabilization and disposal, reference, and no disposal action alternatives, respectively.

\subsection{EXISTING TANK WASTE}

Tank wastes are retrieved, the strontium, casfum, technetium, and TRV are separated for vitriffcation, and residual wastes as grout are sent to low-level waste burial grounds or tanks. The tanks are filled with appropriate material and sealed, soil contaminated from tank leaks is left in place, and the tank farms are covered with soil.

\subsubsection{Mechanical Retrieval}

This operation retrieves salt cake and sludge from single-shell tanked waste without direct addition of water (Figure 5.1).

\subsubsection{Description of Operation and Facility}

The mechanical retrieval operation is designed to occur with mininum alterations to the tank dome structure and to the tank farms in general, and is structured to avold direct loads to the dome. The conceptual recovery process is composed of three sequential operations:

- in-tank recovery of waste

- removal of waste from the tank to a transfer point for emplacenent in a shipping container

- transfer of waste to an onsite processing facility. 
TABLE 5.1. Geologic Disposal Alternative Potential Accidental Releases for Operations Involving Six Waste Forms

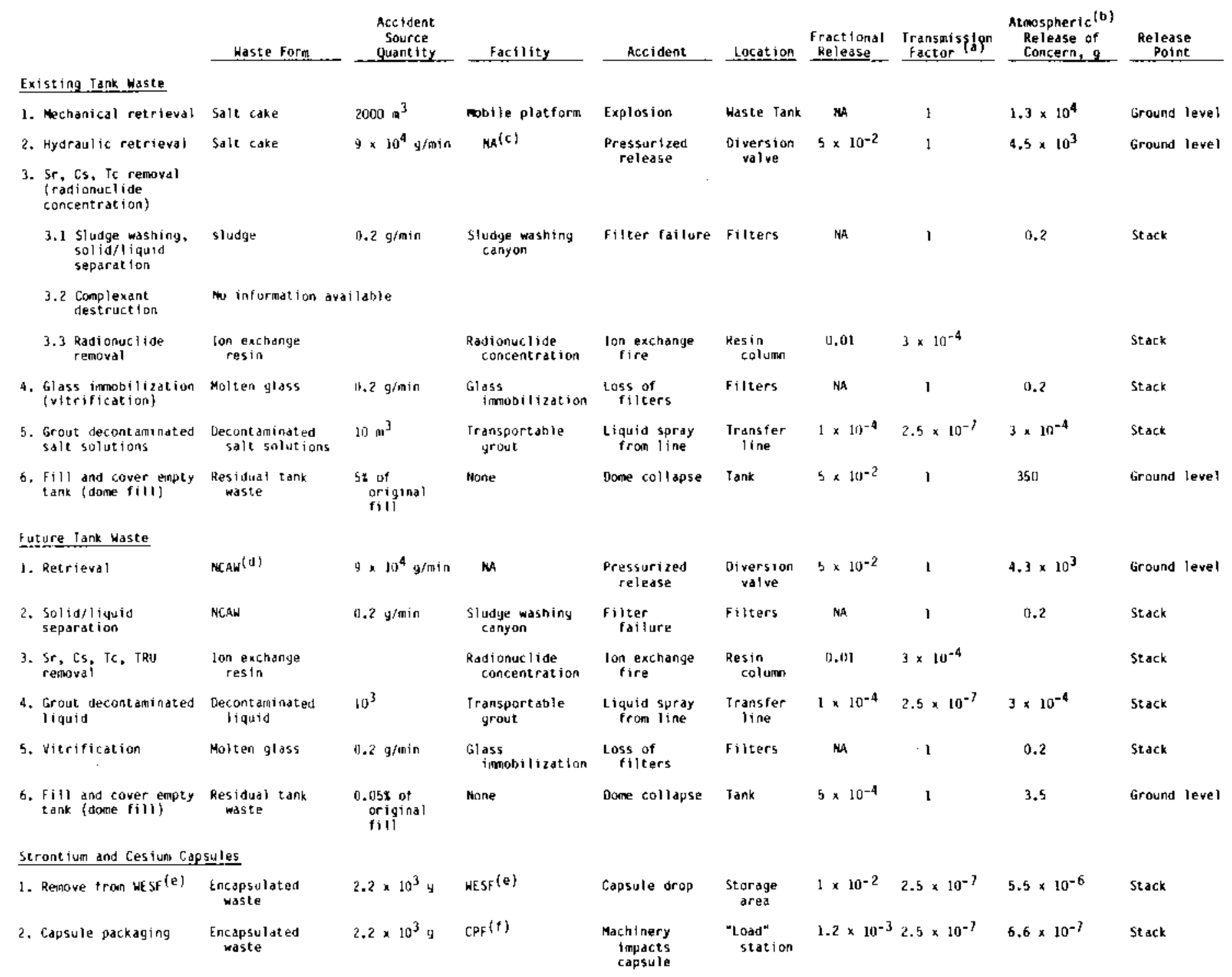


TABLE 5.1. (contd)

\begin{tabular}{|c|c|c|c|c|c|c|c|c|c|}
\hline & Haste fore & $\begin{array}{l}\text { Accident } \\
\text { Source } \\
\text { Quantity }\end{array}$ & Facility & Accident & Location & $\begin{array}{l}\text { Fractional } \\
\text { Release }\end{array}$ & $\begin{array}{l}\text { Transmissign } \\
\text { Factor }\end{array}$ & $\begin{array}{l}\text { Atmospheric }(b) \\
\text { Release of } \\
\text { Concern, } g \\
\end{array}$ & $\begin{array}{r}\text { Release } \\
\text { Point } \\
\end{array}$ \\
\hline \multicolumn{10}{|l|}{ IRU-Contaninated Soil } \\
\hline 1. Retrleve & $\begin{array}{l}\text { Contaninated } \\
\text { soli }\end{array}$ & & $\begin{array}{l}\text { Retrieval } \\
\text { facility }\end{array}$ & Explosion & $\begin{array}{l}\text { Battery } \\
\text { charging } \\
\text { area }\end{array}$ & & 1 & 5 & Ground leve? \\
\hline 2. Process & $\begin{array}{l}\text { Slagging pyrolysis } \\
\text { off gas }\end{array}$ & & $\operatorname{SP1}(9)$ & Explosion & Gasifier & & 1 & 50 & Ground level \\
\hline \multicolumn{10}{|l|}{ Pre-1970 TRU Solid Haste } \\
\hline 1. Retrieve & $\begin{array}{l}\text { Contaminated } \\
\text { soili/waste }\end{array}$ & & $\begin{array}{l}\text { Retrieval } \\
\text { facility }\end{array}$ & Explosion & $\begin{array}{l}\text { Battery } \\
\text { chargingy } \\
\text { area }\end{array}$ & & 1 & 5 & Ground level \\
\hline $\begin{array}{l}\text { 2. Sorting and related } \\
\text { operations }\end{array}$ & Packaged waste & $2 \times 10^{5} 9$ & SPI & $\begin{array}{l}\text { Pressurized } \\
\text { release }\end{array}$ & Orum & 0.01 & $2.5 \times 10^{-7}$ & $5 \times 10^{-4}$ & Stack \\
\hline 3. Process & $\begin{array}{l}\text { Slagging pyrolys is } \\
\text { off gas }\end{array}$ & & SPI & Explosion & Gasifier & & 1 & 50 & Ground level \\
\hline \multicolumn{10}{|c|}{ Retrievably Stored and Newly Generated TRU } \\
\hline $\begin{array}{l}\text { 1. Release } \\
1.1 \mathrm{RH}^{\mathrm{T}} \mathrm{TR}(\mathrm{h})\end{array}$ & Packaged maste & $3.7 \times 10^{3} \mathrm{~g}$ & $\begin{array}{l}\text { Catsson } \\
\text { retrieval }\end{array}$ & $\begin{array}{l}\text { Pressurized } \\
\text { release }\end{array}$ & Metal can & 0.01 & $2.5 \times 10^{-7}$ & $9.3 \times 10^{-6}$ & Stack \\
\hline 1.2. $\mathrm{CH} \mathrm{TRU}^{(1)}$ & Packaged waste & $2 \times 10^{5} \mathrm{~g}$ & None & $\begin{array}{l}\text { Pressurized } \\
\text { release }\end{array}$ & Drum & 0.01 & 1 & $2 \times 10^{3}$ & Ground level \\
\hline $\begin{array}{l}\text { 2. Sorting and Related } \\
\text { Operations } \\
2.1 \text { RH TRU }\end{array}$ & Packaged waste & $2 \times 10^{5} 9$ & SPI & $\begin{array}{l}\text { Pressurized } \\
\text { release }\end{array}$ & Druin & 0.01 & $2.5 \times 10^{-7}$ & $5 \times 10^{-4}$ & Stack \\
\hline $2,2 \mathrm{CH}$ TRU & Packaged waste & $2 \times 10^{5} 9$ & CH WRAP & $\begin{array}{l}\text { Pressurized } \\
\text { release }\end{array}$ & Orum & 0.01 & $2.5 \times 10^{-7}$ & $5 \times 10^{-4}$ & Stack \\
\hline $\begin{array}{l}\text { 3. Process } \\
3.1 \text { RH TRU }\end{array}$ & $\begin{array}{l}\text { Slagging pyrolysis } \\
\text { off gas }\end{array}$ & & SPI & Explosion & Gasifier & & 1 & 50 & Ground level \\
\hline $3.2 \mathrm{CH}$ URAP & Packaged maste & $1 \times 10^{5} \mathrm{~g}$ & CH URAP & Fire & Drum & $5 \times 10^{-4}$ & $2.5 \times 10^{-7}$ & $2.5 \times 10^{-5}$ & Stack \\
\hline \multicolumn{10}{|c|}{$\begin{array}{l}\text { (a) A transmission factor of } 1 \text { means the big } \\
\text { (b) Default assumption - if release is in } 9 / \\
\text { (c) Not Applicable. } \\
\text { (d) Meutralized Current Acid Waste. } \\
\text { (e) Waste Encapsulation and Storage factility } \\
\text { (f) Capsule Packaging Process. } \\
\text { (g) Slagging Pyrolysis Incinerator. } \\
\text { (h) Remote-Handled. } \\
\text { (i) Contact-Handled Waste Retrieval and Pack }\end{array}$} \\
\hline
\end{tabular}




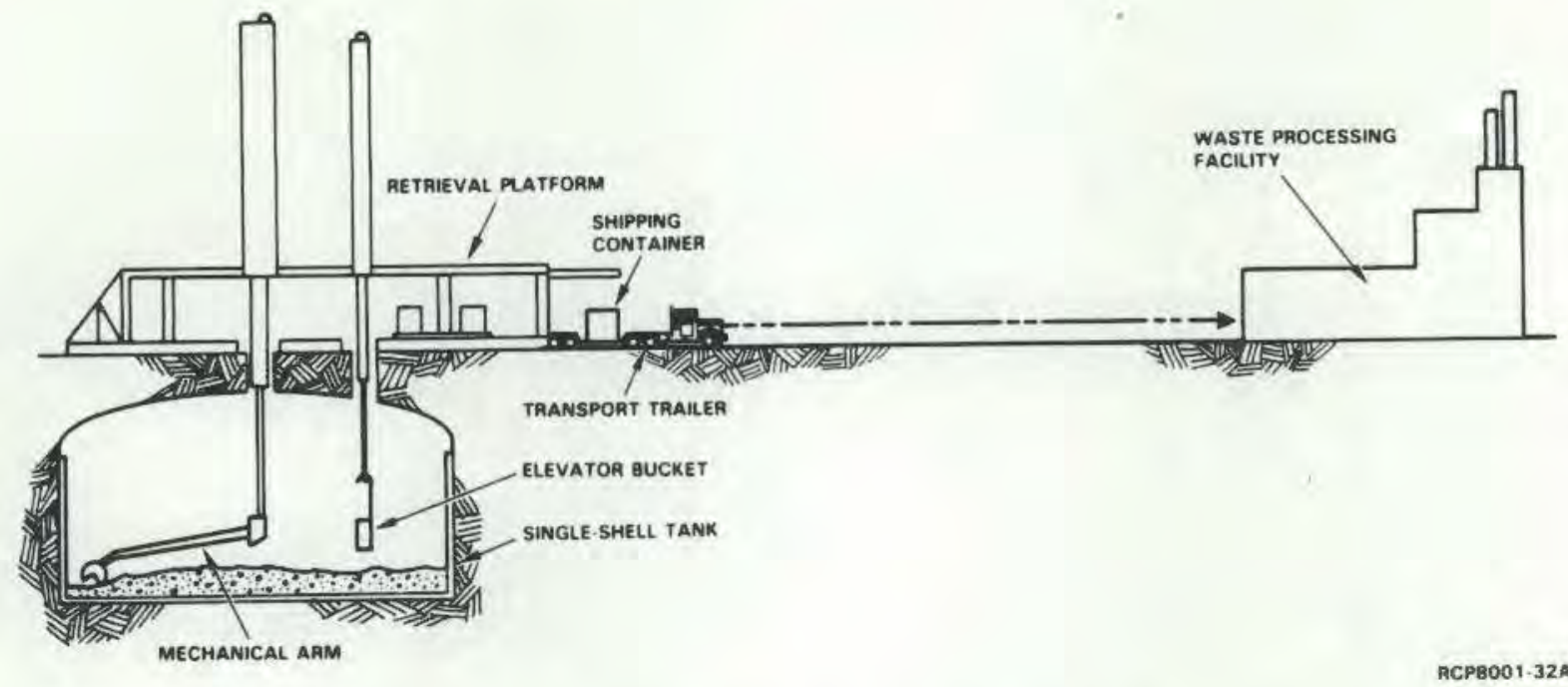

FIGURE 5.1. Mechanical Retrieval of Wastes from Single-Shell Tanks

Single-shell tanks are prepared by adding entry points (risers), if necessary, removing above-ground obstructions, and breaking up large encrustations of waste. The waste recovery, removal, containerization, and most of the supporting equipment are mounted on a movable platform. The mobile platform, sized to the approximate $31-m$ tank spacing, supports the waste-handling apparatus and contains most of the auxiliary systems necessary for safe retrieval of the waste. A hydraulically actuated articulating arm is positioned using a telescoping tube and carriage mechanism in a tower. The tank is maintained slightly below atmospheric pressure during these operations and ventilation air is discharged through two banks of high-efficiency particulate air filters.

The waste retrieval system recovers the waste mechanically with a clamshell bucket on the articulating arm and deposits the waste in the elevator bucket for transfer to the platform level. This recovered as-is waste is unloaded from the bucket elevator to a shielded shipping container that holds approximately $2.7 \mathrm{~m}^{3}$ of waste. After being sealed and washed, the shipping container is placed in a clean, sealed container that is also sealed with a locking 1id. A special tractor-trailer vehicle is used to transfer the container over a dedicated roadway to the onsite processing facility. 


\subsubsection{Postulated Upper-Bound Accident}

Several sources for an explosive release of salt cake could be postulated during mechanical retrieval. The salt cake is composed of many salts; among these is sodium nitrate, a powerful oxidizer. Although experimental work (Beitel 1976) indicated that sodium nitrate can be considered stable below a temperature of $300^{\circ} \mathrm{C}$, a potentially vigorous explosion might result if ferrocyanide precipitates were in the tank. Cyanide and nitrate ions could react violently during the heating and produce an explosion with the energy equivalent to 36 tons of TNT. This explosion would have an impact sufficient to breach the filters, thus releasing aerosol directly to the atmosphere.

\subsubsection{Release Estimate for Upper-Bound Event $4.98 \mathrm{E} 5 \mathrm{Kg}=498 \mathrm{t}$}

Steindler and Seefeldt (1980) developed a method to predict aerosol production from a detonation, which is used to estimate this release. The source is $2000 \mathrm{~m}^{3}$ of salt cake, which releases $4.98 \times 10^{8} \mathrm{~g}$ of aerosol directly to the atmosphere, including $1.3 \times 10^{4} \mathrm{~g}$ of respirable material $10 \mathrm{\mu m}$ aerodynamic equivalent diameter and less. This latter value is the estimated release listed in Tables 5.1 and 5.2 and used for dose calculations.

\subsubsection{Other Accidents Considered}

$$
\frac{1.3 E 4}{4.98 E 8}=2.6 E-5
$$

Other accidents that appeared applicable to the mechanical retrieval were considered as the potential upper-bound release event. They are discussed briefly below and listed in Table 5.2 .

Contaminated Soil Suspension During Sampling. It is believed that such an event would not result in any large, significant airborne release of radionuclides.

Retrieval Transporter Spill. During the mechanical retrieval, it is postulated that due to systems malfunction a shipping container fails to line up under the buck as the transfer operation proceeds. The entire elevator buck is filled with waste that can become airborne in the facility after a spill. 
TABLE 5.2. Postulated Airborne Releases from Accidents During Mechanical Retrieval of Single-Shell Tank Waste

Event

Explosion

Contaminated soil suspension

Retrieval transporter spill

Waste spill

Loss of filtration

1st stage

Both stages

Loss of services

or power
Atmospheric Airborne Release

$1.3 \times 10^{4}$ respirable $=13 \mathrm{Kg}$

Significantly below upper-bound

Significantly below upper-bound

Significantly below upper-bound

$5 \times 10^{-6} \mathrm{~g} / \mathrm{m}^{3}$
$1 \times 10^{-2} \mathrm{~g} / \mathrm{m}^{3}$

No significant release

The fraction airborne under these circumstances can be estimated as $0.12 \%$, based on experimental measurements of free-fall spill releases (Sutter, Johnston and Mishima 1981). It is assumed that the airborne material enters the transporter exhaust system and is filtered by two stages of high-efficiency particulate air filters before release to the atmosphere.

Waste Spill. If this event occurred on the platform leve1, the release would be that mentioned above. If the event occurred in the tank, then the release is postulated to be similar to that shown for the loss of filtration discussed below.

Waste Spill During Retrieval. It is postulated that material is dropped from the clamshell or elevator bucket as a result of equipment malfunction. The material is released in the waste tank and must therefore pass through two stages of high-efficiency particulate air filtration before release to the atmosphere. The exhaust rate through the tank is low; therefore it is not assumed that an inordinate amount of material would be made airborne. Based on aerosol behavior, a quasi-stable concentration of $100 \mathrm{mg} / \mathrm{m}^{3}$ is assumed (ORNL 1970) with $10 \%\left(10 \mathrm{mg} / \mathrm{m}^{3}\right)$ as respirable particles less than $10 \mu \mathrm{m}$ aerodynamic equivalent diameter. 
Loss of filtration. The quantity airborne during the mechanical retrieval operation of salt cake will be high due to the dusty nature of the operation. It is assumed that the mechanical subdivision of the salt cake will result in a coarse particle size distribution for the material airborne. A value of $100 \mathrm{mg} / \mathrm{m}^{3}$ with $10 \%$ in the respirable size fraction is conservatively selected. Loss of one stage of filtration would increase the transmission factor of material challenging the filters to a 0.0005 fraction. Loss of both stages of filtration would increase the transmission factor to 1.

Loss of Services or Power. It is postulated that the only consequences of service or power loss would be the cessation of operations and that no significant airborne release of material would occur.

\subsubsection{Hydraulic Retrieval}

\subsubsection{Description of Operation and Facility}

This operation recovers and transfers radioactive liquids using multistage pumps, deep-well turbine pumps, and shielded piping as shown in Figure 5.2.

Slurries are removed from double-shell tanks with a sluicer such as the one shown in Figure 5.3. The sluicer is composed of two basic systems:

- the high-pressure water supply system, made up of a remote piping connector, vertical pipe, flex hose, rotary joint, and nozzle assembly

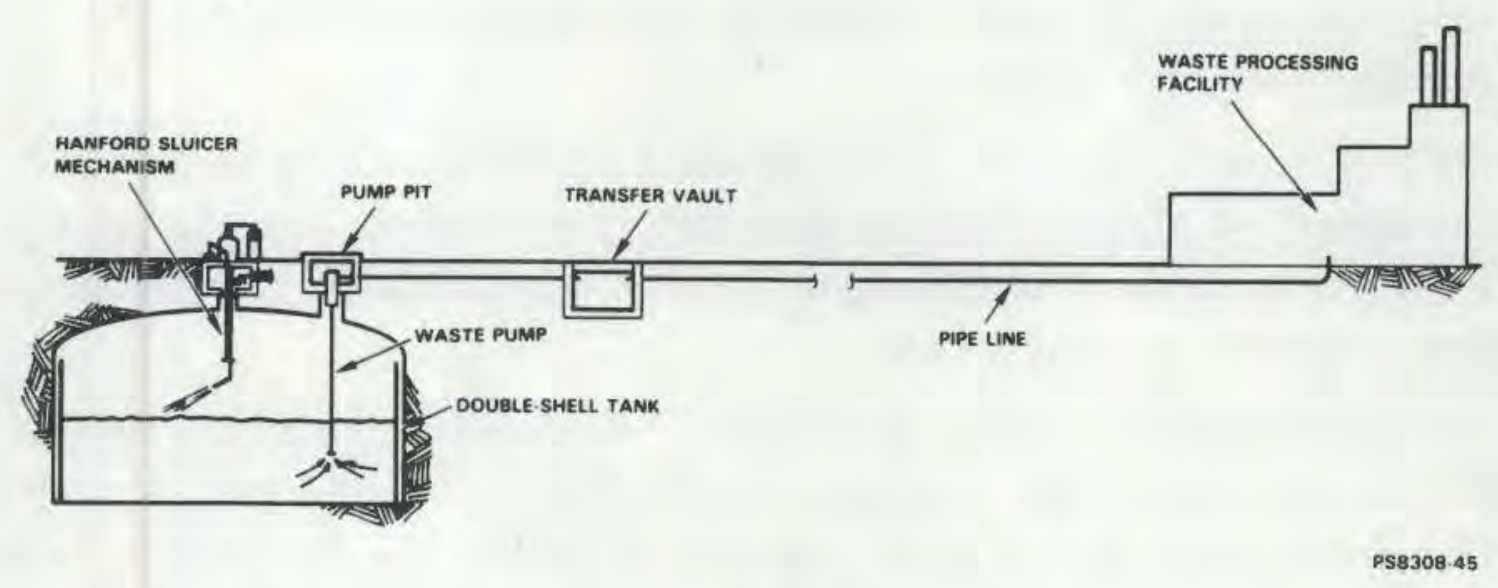

FIGURE 5.2. Hydraulic Retrieval of Waste from Double-Shell Tanks 


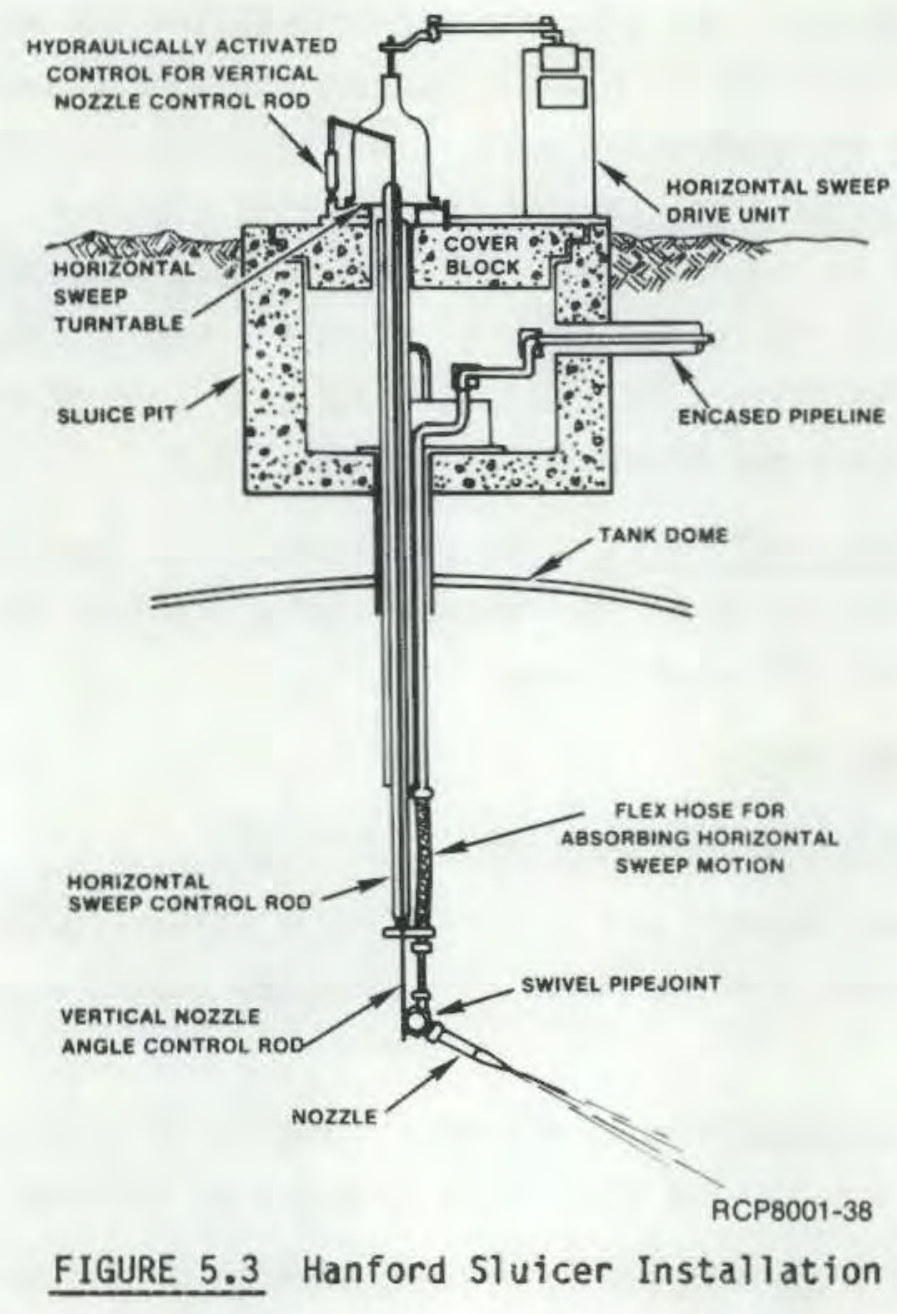

- the nozzle-aiming mechanism, consisting of two concentric control rods in a guide tube, nozzle assembly, turning arm, and gear rod for turning the rotary joint.

The tank is maintained at a slightly negative pressure, and air is discharged through two high-efficiency particulate air filters. Transfer of the slurry and liquid to waste processing facilities or other tanks will be accomplished by methods currently in use.

The concentration of waste in the slurry is assumed to be in the form of insoluble particles and $\sim 25 \%$ by volume, which is similar to slurries of coal or gravel that are pumped (Perry 1973). While some of the contamination is in the form of soluble nuclides, we are unable to identify this portion in the present 
analysis. At $0.2 \mathrm{~m}^{3} / \mathrm{min}$ pumped (ESG 1980), the $25 \%$ by volume (i.e., the radioactive material) pumped would be $0.05 \mathrm{~m}^{3} / \mathrm{min}$. Assuming a waste density of $1.8 \times 10^{6} \mathrm{~g} / \mathrm{m}^{3}$, this is $9 \times 10^{4} \mathrm{~g} / \mathrm{min}$ of salt cake pumped.

\subsubsection{Postulated Upper-Bound Accident}

A pressurized release of the liquid waste is postulated as an upper-bound release event. Recycled liquid could be pumped to some manifold where that liquid or external liquid could be used for the sluicer. If the manifold is located in a facility which is not a nuclear-grade facility or the external tanks are not enclosed, failure of the diversion valve could result in the backflow of waste solution into the unenclosed area and the spray release of the liquid until pumping was stopped. The material released but not made airborne would be subjected to resuspension. The material could be jetted from the pipe and perhaps become airborne as a spray that is carried by the prevailing wind. Even at the nominal wind speed found at Hanford of $7.6 \mathrm{mph}$ (Stone 1972), 5\% of the sprayed material could be made airborne (Sutter 1980). If the wind velocities were substantially higher, even more could become airborne.

\subsubsection{Release Est imate for Upper-Bound Accident}

The parameters presented above can be used to calculate the release (1isted in Table 5.3).

$$
\begin{aligned}
& \text { (pumped/min) (fractional release) }=\mathrm{g} / \mathrm{min} \\
& \qquad 9 \times 10^{4} \mathrm{~g} / \mathrm{min} \times 5 \times 10^{-2}=4.5 \times 10^{3} \mathrm{~g} / \mathrm{min}=75 \mathrm{~g} / \mathrm{s}
\end{aligned}
$$

This system would be monitored, and it could be assumed that a safety system would activate a response of shutting down the pump in a reasonable time. A one-minute release is assumed.

\subsubsection{Other Accidents Considered}

Accidents with lower releases were considered and are also listed in Table 5.3. 


\section{TABLE 5.3. Postulated Airborne Releases from Accidents During Hydraulic Retrieval of Double-Shell Tank Waste}

\begin{tabular}{ll}
\multicolumn{1}{c}{ Event } & Atmospheric Airborne Re \\
\hline $\begin{array}{l}\text { Diversion valve } \\
\text { failure }\end{array}$ & $4.5 \times 10^{3} \mathrm{~g}$ \\
$\begin{array}{l}\text { Slurry spill } \\
\text { Loss of service or } \\
\text { power }\end{array}$ & $\begin{array}{l}1 \times 10^{-4} \text { fraction, plus } \\
\text { resuspension }\end{array}$ \\
$\begin{array}{l}\text { Loss of filters } \\
\text { 1st stage }\end{array}$ & $4 \times 10^{-5} \mathrm{~g} / \mathrm{min}$ \\
2nd stage & $7 \times 10^{-2} \mathrm{~g} / \mathrm{min}$
\end{tabular}

Slurry Spill (Pipe Break). It is assumed that a pipe connection fails due to some external event which also damages the pipe shielding. The breach allows the entire flow to discharge to the soil, but remnants of the shielding prevent the interaction of the liquid and wind. Therefore, it is assumed that the immediate airborne release is similar to a liquid spill, and on the basis of experimental measurement of free-fall liquid spills, $0.01 \%$ of the slurry is estimated to become airborne (Sutter, Johnston and Mishima 1981). The total release would be the fraction airborne times the volume leaked plus the quantity resuspended by the wind until remedial measures could be effected. Sehmel (1979) suggested a resuspension rate of $10 \times 10^{-8} / \mathrm{sec}$ as a conservative value for yearly average Hanford conditions.

Loss of Services or Power. Loss of services or power is visualized as stopping any operations or systems. Loss of flow without loss of filtration would result in back diffusion after some period but is not viewed as a significant release potential. Cessation of the operation does not appear to have serious release potential for this operation.

Loss of Filtration. In the event of loss of one or more stages of highefficiency particulate air filtration due to some indeterminant event (i.e., 
the accumulation of moisture upon the filters, pressurization within the waste tank, etc.), the material airborne within the tank could be released to the atmosphere.

During the operation, the tank ventilation system is assumed to operate at a rate of $20 \mathrm{~m}^{3} / \mathrm{min}$ carrying $10 \mathrm{mg} / \mathrm{m}^{3}$ meter of slurry. At an assumed slurry density of $1.2 \mathrm{~g} / \mathrm{cm}^{3}, 0.07 \mathrm{~g}$ of slurry particles/min challenge the filters. With loss of a single stage of filtration without loss of flow (and neglecting the increase of flow due to the decreased pressure drop), the transmission factor through the filters increases to 0.0005 and the emission to the atmospheres rises to $3.5 \times 10^{-5} \mathrm{~g} / \mathrm{min}$. Loss of both stages of filtration increases the transmission factor to 1 , and the $0.07 \mathrm{~g} / \mathrm{min}$ are released to the atmosphere.

\subsubsection{Radionuclide Concentration}

In the radionuclide concentration facility, strontium, cesium, technetium, and TRU elements would be removed from soluble salts to prepare material suitable for either glass immobilization or grouting. This is discussed as a single operation in the Hanford Defense Waste Environmental Impact Statement; however, it is really a series of processes as shown in Figure 5.4. These

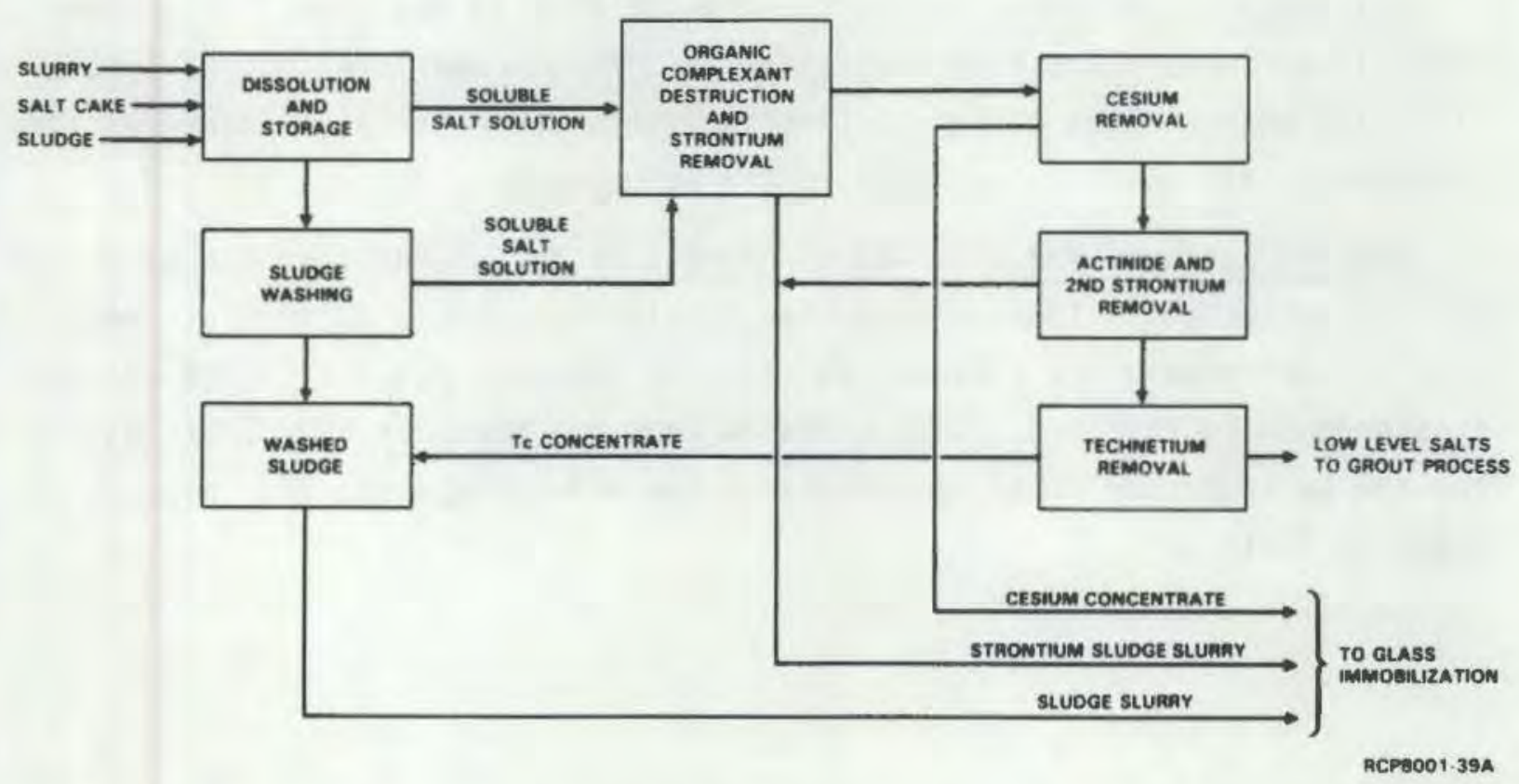

FIGURE 5.4. Schematic Flowsheet for Radionuclide Concentration Processes 
processes are essentially three operations: sludge washing and solids/liquid separation, complexant destruction, and removal of various radionuclides. Releases from these operations are discussed in the following sections.

\subsubsection{Sludge Washing and Solid/Liquid Separation}

This operation dissolves salts that would otherwise remain entrained in the high-level solids. Removal of these salts minimizes the amount of glass being produced.

Description of Operation and Facility. Initial separation is performed by a solid-bowl centrifuge. Then separated sludge/solids are washed three times, again in the solid-bowl centrifuge. Centrifuge solids holdup capability, coupled with estimates of time cycles, provided an estimated nominal throughput capability of 10 metric tons of uranium per operating day. The effluent from jet entrainment in the solid/liquid separation and sludge washing operations would be discharged to the atmosphere through a vessel vent off-gas system.

Figure 5.5 is a conceptual drawing of a facility for radionuclide concentration with a sludge washing canyon identified. Additional information on the facility, equipment, or process is not available.

Postulated Upper-Bound Accident. Loss of flow is not viewed as a highpotential airborne release hazard; therefore, this scenario addresses loss of filtration without loss of flow. In this event, the material airborne within the process cell would be released to the atmosphere.

Release Estimate for Upper-Bound Event. It is assumed that the airborne mass concentration is $10 \mathrm{mg} / \mathrm{m}^{3}$ and the ventilation rate is $20 \mathrm{~m}^{3} / \mathrm{min}$. Under these circumstances, $0.2 \mathrm{~g} / \mathrm{min}$ of particulate material present in the process is assumed to be released. This scenario does not consider the particle loss from the duct work or other components of the off-gas system. The release is listed in Table 5.4 . 


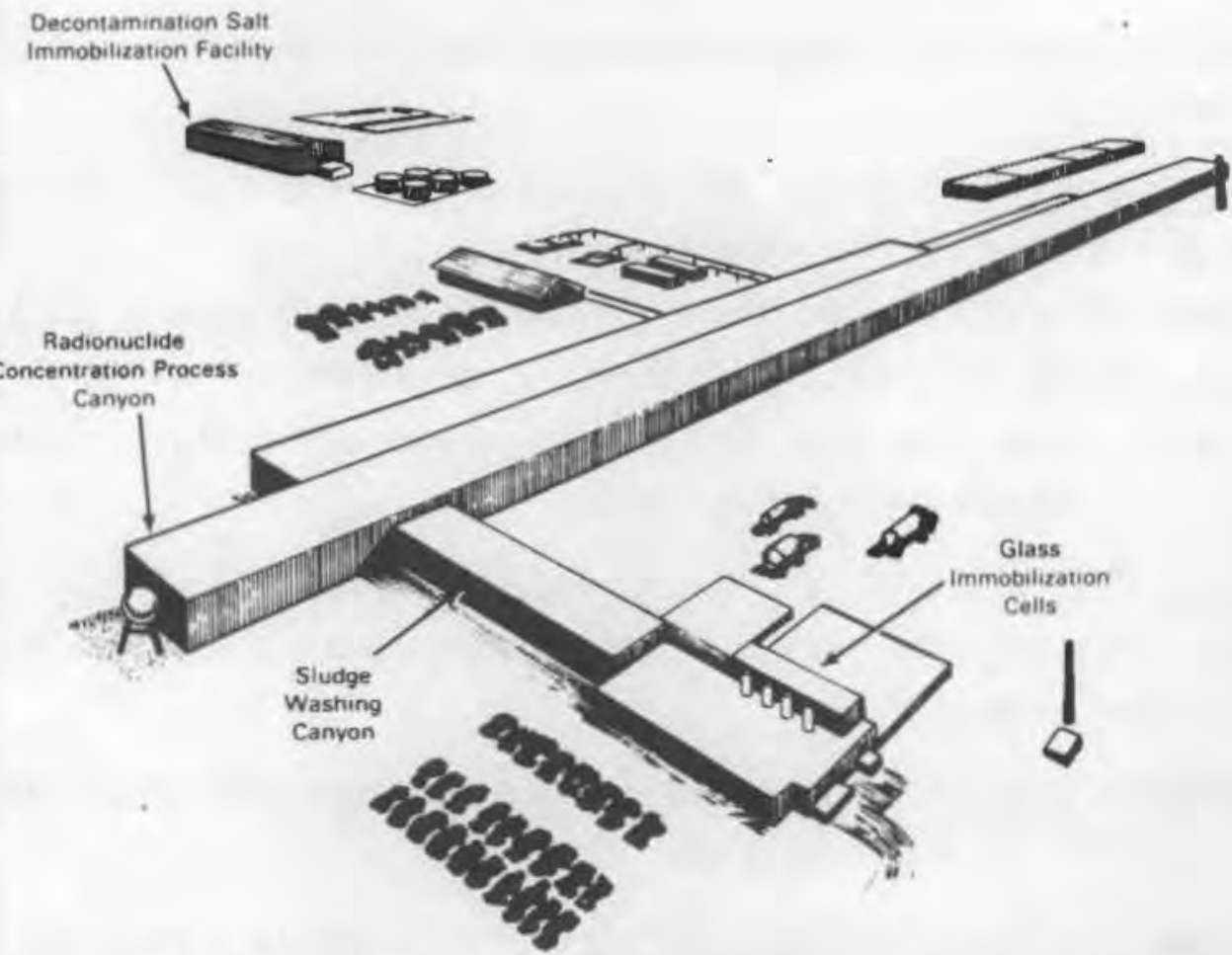

FIGURE 5.5. Conceptual Facility for Radionuclide Concentration

TABLE 5.4. Postulated Airborne Releases from Accidents During Sludge Washing and Solid/Liquid from Separation Tank Waste

\begin{tabular}{|c|c|}
\hline Event & Atmospheric Airborne Release \\
\hline Loss of exhaust system & $0.2 \mathrm{~g}$ \\
\hline $\begin{array}{l}\text { Evaporation spill/ } \\
\text { rupture }\end{array}$ & $3 \times 10^{-16}$ fraction (a) \\
\hline Leaks & $\begin{array}{l}\text { Significantly below upper- } \\
\text { bound }\end{array}$ \\
\hline Centrifuge rupture & $7 \times 10^{-14}$ fraction $(b)$ \\
\hline Hydrogen explosion & $6 \times 10^{-9}$ fraction $(c)$ \\
\hline Fire in cell & Significantly below upper-bound \\
\hline Filter fire & Covered by upper-bound \\
\hline $\begin{array}{l}\text { Loss of services or } \\
\text { power }\end{array}$ & No significant release \\
\hline
\end{tabular}

(a) Hayward and Jensen (1980).

(b) Richardson (1980).

(c) DOE 1982). 
Other Accidents Considered. Releases from less than upper-bound accidents are included in Table 5.4.

- Evaporator Spill/Rupture. It is assumed that material is spilled or leaked from the evaporator and would be equal to the free-fall release of liquids. The energy or conditions generated by this event would not result in loss of filtration; therefore the airborne release consequences are limited. An estimated fractional release is $3 \times 10^{-16}$ (Hayward and Jensen 1980).

- Leaks. Several tanks, sludge, slurry, or washed sludge, could leak. They could be assumed to have consequences similar to the evaporator leak.

- Centrifuge Rupture. This event had a postulated fractional release of $7 \times 10^{-14}$ (Richardson 1980).

- Hydrogen Explosion in the Feed Tank. Four possible situations have been suggested (DOE 1982) that could result in an explosion: 1) red oil formation, 2) hydrogen accumulation, 3) mercury or silver compound inclusions, and 4) ammonium nitrate avallable. None of these events appears to compromise the filtration system and therefore the release consequences are less than loss of filtration. The fractional release was estimated at $6 \times 10^{-9}$.

- Fire in the Cell. Combustible materials are also prevalent in hot cells, generally in the waste, but also as lubricants, etc. Fires in the process cell would more likely plug than destroy the filters which are usually some distance from the cells. Therefore, the release from such an event is felt to be less than by loss of filtration.

- Filter Fire. Unless the radionuclides accumulated on the filter are volatile at elevated temperatures, subjecting the filter to heat is felt to result in the shrinking of the glass filter and trapping of the particles accumulated. The consequences would result in loss of filtration, which has already been covered. 
- Loss of Services or Power. Loss of services or power would primarily lead to cessation of operations, which does not appear to result in serious airborne release hazards in this operation.

\subsubsection{Complexant Destruction}

This process will be performed, but the operation has not yet been defined. Therefore, no accidents are postulated.

\subsubsection{Radionuclide Removal}

This process removes all radionuclides with greater than $10-y r$ half-lives from soluble salt wastes. This separates high-level waste for immobilization, and a large volume of low-level chemical waste that can be disposed of in a relatively inexpensive way.

Description of Operation and Facility. Strontium and actinides remaining in solution after sludge removal are removed by a combination of precipitation and adsorption on sodium titanate ion exchanger (the conditions, materials and equipment used for the precipitation are not defined). Spent sodium titanate is added to the strontium precipitate solution, and the slurry is transferred to the immobilization portion of the facility. The supernatant liquid from the strontium precipitation is filtered through sand filters for the removal of trace solids. The cesium is then removed in an ion exchange column loaded with Duolite ARC-359 (Diamond Shamrock Company). The cesium is eluted with an ammonium carbonate solution, which is steam-stripped to separate the effluent from the cesium product. The cesium solution is also transferred to the immobilization portion of the facility.

Technetium is removed from the cesium ion exchange column waste stream by adsorption on an anton exchange resin. The technetium is eluted with nitric acid and the product stream distilled to recover the nitric acid. The concentrated product is neutralized with sodium hydroxide and added to the sludge waste, which is transferred to the immobilization process.

The waste stream leaving the technetium ion exchange column is essentially a sodium salt waste containing trace amounts of radionuclides. Ruthenium and iodine, like the sodium salts, are contaminants and are virtually unaffected by the separation process. The ruthenium concentration is low because of the long 
decay time. After being monitored in collection tanks, the salt solution is transferred to the grout mixing process.

Process off gases are treated for the removal of particulates, radionuclides, oxides of nitrogen, and ammonia before release to the atmosphere. The nitric acid resulting from the distillation of the technetium product is recovered and reused. Ammonia and carbon dioxide are recovered, recombined, and reused in elution of cesium from the fon exchange column. Liquid effluents are minimized by recycling. Cooling water is reused after passing through a suitable cooling process. Steam condensate is returned to the process. Steam condensate and cooling water not recycled are sampled and discharged to evaporation ponds. Wastes not meeting the limits for discharge are concentrated and blended into the process.

Postulated Upper-Bound Accident. It has been postulated in several references that an ion exchange column loaded for 2 days ignites and ruptures (DOE 1982, Hayward and Jensen 1980, ESG 1980). All of the activity on the resin is released and a portion becomes airborne. The building ventilation system is not impacted by the event and continues to function.

Release Estimate for Upper-Bound Event. In one scenario, all the activity on the resin is released, with $0.002 \%$ becoming airborne. The building ventilation system continues to function with a transmission factor of $10^{-5}$ (Rockwell 1980). A similar scenario is presented in DOE (1982) with a 0.01 fraction of the activity made airborne and with a transmission factor of $3 \times 10^{-4}$, resulting in an atmospheric fractional release of $3 \times 10^{-6}$. The larger values are listed in Table 5.5 and are suggested for dose estimates.

Other Accidents Considered. These less than upper-bound releases are included in Table 5.5 .

- Ion Exchange Tank Leak. It is postulated that due to a loose connection, corrosion, etc., liquid leaks from a vessel containing concentrated solution from the process. The airborne release would be analogous to a free-fall spill, and the event does not compromise the filtration system. The airborne release is considered less than that given above for the ion exchange column fire. 


\section{TABLE 5.5. Postulated Airborne Releases from Accidents}

During Radionuclide Removal from Tank Waste

\begin{tabular}{lll} 
Event & & Atmospheric Airborne Release \\
\cline { 1 - 1 } Ion exchange fire & $3 \times 10^{-6}$ fractional release \\
Ion exchange tank leak & Significantly below upper-bound \\
Equipment failure & No significant release
\end{tabular}

- Equipment Failure. Release values for equipment failure postulated by Hayward and Jensen (1980) indicate that the anticipated release is less than that for an ion exchange column fire.

\subsubsection{Glass Immobilization (Vitrification)}

\subsubsection{Description of Operation and Facility}

The glass immobilization process discussed in this section would be used in conjunction with the radionuclide concentration process in cells identified in Figure 5.5. It is designed to be operated continuously at $72 \%$ operating efficiency for 18 years. The slurries from radionuclide concentration would be blended with a glass frit composed of silicon dioxide $\left(\mathrm{SiO}_{2}\right)$, boron oxide $\left(\mathrm{B}_{2} \mathrm{O}_{3}\right)$, sodium oxide $\left(\mathrm{Na}_{2} \mathrm{O}\right)$, and lithium oxide $\left(\mathrm{Li}_{2} \mathrm{O}\right)$, and melted to a homogeneous glass in ceramic-lined melters that are heated internally by electrical conduction through the molten glass (joule heating). The molten glass stream poured from the melters would be cast directly into carbon steel canisters $0.61 \mathrm{~m}$ diameter by $3-\mathrm{m}-1$ ong. The product glass would contain about $25 \mathrm{wt \%}$ waste oxides.

Radionuclide concentration process sludge and concentrate streams would be pumped as slurries from the main canyon facility (radionuclide concentration process) to the immobilization wing. The slurries would be blended with weighted quantities of glass-forming ingredients $\left(\mathrm{SiO}_{2}, \mathrm{~B}_{2} \mathrm{O}_{3}, \mathrm{Na}_{2} \mathrm{O}\right.$, and $\left.\mathrm{Li}_{2} \mathrm{O}\right)$. A relatively small quantity of glass frit from the off-gas filter would be added to the feed batch as a recycle stream.

The melter concept under evaluation and development for Hanford waste immobilization is the slurry-fed, joule-heated, ceramic-lined continuous melter. This design offers the potential for long life, high processing rate, 
and high glass quality. To employ joule heating, the melter would be equipped with electrodes between which electrical energy would dissipate within the molten glass. Estimated dimensions of a continuous electric melter for producing $4 \mathrm{t}$ of glass per day are shown in Figure 5.6. The waste and glass additives would pass through three partially overlapping phases as they are incorporated into the glass pool: an evaporation phase in which the slurry is dried, a calcining phase in which dried wastes decompose to form oxides, and the molten glass phase. The relatively cool blanket of oxides and wet sludge condenses most of the escaping volatile radionuclides and refluxes them to the molten pool. The resulting gaseous effluent would contain all of the water, $\mathrm{NO}_{x}, \mathrm{CO}_{2}$, and some of the $\mathrm{SO}_{x}$ in the melter feed, and (during infrequent periods of abnormal blanket distribution) up to $5 \%$ of the cesium.
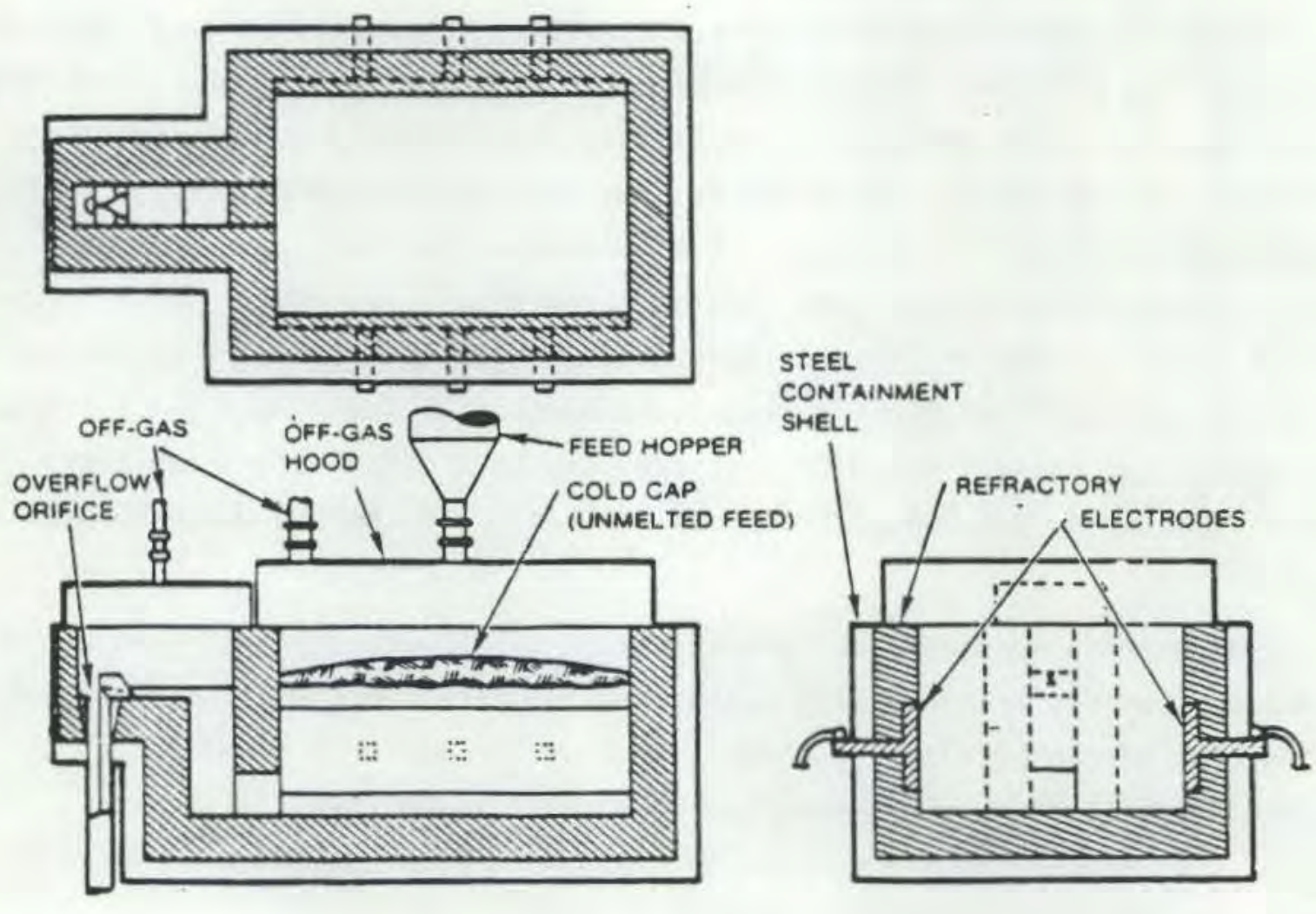

ACP8001-29

FIGURE 5.6. Continuous Electric Glass Melter 
Present assumptions are for three melters--two operating and one spare--to achieve an effective rate of $8 \mathrm{t}$ per day. Glass would be allowed to pour from a melter to fill carbon-steel canisters in a continuous casting operation. When a canister was full, the pour of molten glass would be stopped and the canister moved to another location for cooling. When cool, the canister would be moved to decontamination, welding, and nondestructive testing stations for final closure and inspection before transfer to the loadout facility.

The melter off-gas stream would be routed first through a rechargeable filter bed composed of a ground glass frit and maintained at a temperature of about $157^{\circ} \mathrm{C}$. Here dust particles would be filtered and some volatiles (cesium and ruthenium) condensed and trapped. When the bed was replaced the trapped materials would be recycled to the feed blending system. Water vapor, $\mathrm{NO}_{\mathrm{x}}$, and $\mathrm{SO}_{\mathrm{x}}$ would be finally removed via condenser and scrubber using a sodium carbonate $\left(\mathrm{Na}_{2} \mathrm{CO}_{3}\right)$ solution. (The scrubber also would serve as a secondary decontamination step for volatilized cesium.) This contaminated solution of nitrate and sulfate salts would be recycled to the head-end of the radionuclide concentration process. The salts ultimately would leave the process in the decontaminated salt stream.

Because of multiple mechanical operations and solids-handling steps in the process, a combination of in-cell cranes, manipulators, and viewing windows would be used for remote maintenance and control. The glass conversion process would be conducted in three hot cells with shielding walls $1.1 \mathrm{~m}$ thick. The hat cells would provide a total cell floor area of $285 \mathrm{~m}^{2}$. A high bay or canyon would cover the entire cell complex and provide access by the 70 -ton canyon crane to the cells below.

\subsubsection{Postulated Upper-Bound Accident}

The simultaneous loss of both the melter and facility filtration appears to be an event with a low probability of occurrence. Even total loss of the facility filtration is highly unlikely. For the purposes of this analysis, however, it is postulated that such an event occurs and the material airborne in the canyon is released to the atmosphere without filtration. 


\subsubsection{Release Estimates for Upper-Bound Event}

As in Section 5.1.2.4 of this report, the same mass concentration and flow are assumed, resulting in $0.2 \mathrm{~g} / \mathrm{min}$ of glass being released. Since the melter has its own filtration system, the operation is not perceived to be a dusty one. A filter fire is once again assumed to result in the release of little of the accumulated material and is essentially the same airborne release as from the loss of filter alone. The release is listed in Table 5.6.

Cesium, if associated with the waste, could volatilize at elevated temperatures and release to the atmosphere if control systems fail. Cesium volatility is a function of temperature. Experimental cesium releases in percent per hour at $1000^{\circ} \mathrm{C}$ were: $1 \%$ (Albrethson and Schwendiman 1967), 1.5\% (Gray 1976), and 4.2\% (Walmsley et al. 1969). Volatility increases further at higher temperature levels.

\subsubsection{Other Accidents Considered}

Table 5.6 includes the releases from the other accidents considered.

Molten Glass Spill. "Should the molten glass spill from the melter onto the canyon floor, the glass would flow and solidify, releasing little

TABLE 5.6. Postulated Airborne Releases from Accidents During Waste Vitrification of Tank Waste

\begin{tabular}{|c|c|}
\hline Event & Atmospheric Airborne Release \\
\hline $\begin{array}{l}\text { Failure of of } f \text {-gas } \\
\text { system }\end{array}$ & $0.2 \mathrm{~g}$ \\
\hline Molten glass spill & Significantly below upper-bound \\
\hline Melter feed tank leak & Significantly below upper-bound \\
\hline $\begin{array}{l}\text { Explosion in glass } \\
\text { melter/steam } \\
\text { explosion }\end{array}$ & $3 \times 10^{-8}$ fractional $r$ \\
\hline Waste canister failure & $3 \times 10^{-10}$ fractional release $(a)$ \\
\hline Cell fire & No significant release \\
\hline $\begin{array}{l}\text { Loss of services or } \\
\text { power }\end{array}$ & No significant release \\
\hline
\end{tabular}

(a) DOE (1982). 
radioactivity to the canyon" (DOE 1982). Thus, it is estimated that the airborne release to the atmosphere from such an event would not be significant, especially since any material released to the canyon must still pass through the filtration system.

Melter Feed Tank Leak. The consequences of this event are viewed by Hayward and Jensen (1980) as the leak of a liquid which has been covered several times in previous sections.

Explosion in Glass Melter/Steam Explosion in Glass Melter. DOE (1982) suggested the following event.

"Although contact between the glass and water does not normally lead to a steam explosion, entrapment of water under molten glass, either in the melter or on the floor, in conjunction with the following factors would more likely cause such an event, 1) low water temperature, 2) high glass temperature, 3) shallow water depth, 4) rust on the surface beneath the water, 5) ionic content in water (e.g., salt), and 6) forced injection of glass into water. There is only a remote possibility that the water could get trapped beneath the molten glass in the melter. A failure of the cooling system and of the drain system followed by a failure of the glass melter could lead to entrapment of water beneath molten material, causing an explosion.

The molten glass will fragment into a large number of small particles by the shock of the explosion and scatter throughout the canyon. Approximately 0.01 wt\% of the fragmented glass is estimated to be carried into the ventilation system. At the time of the explosion, the melter is assumed to contain $1000 \mathrm{~L}$ of product. A filter factor of $3 \times 10^{-4}$ is given resulting in a release of $3 \times 10^{-8}$ fraction (or $0.03 \mathrm{~cm}^{3}$ of glass)."

Waste Canister Failure. Waste canisters can be breached before encapsulation if they are dropped in handling operations (OOE 1982). For the purposes of this analysis, it is assumed that the rupture is equivalent to a cover block drop on an encapsulated canister.

Cell Fire. It is questionable that any combustibles could be tolerated in a cell with the potential high temperatures from the glass melting operation. Therefore, a fire is considered an unlikely scenario with no significant release.

Loss of Services or Power. Loss of service or power could result in a variety of consequences depending on which services failed and which continued 
to operate. Loss of power would result in cessation of operations. However, some releases could continue until the melt cooled. They could be carried to the filters by diffusion since there would be no airflow, and filters would capture them. Loss of airflow without loss of power would mean continued heating and release carried to the filters. Emergency shutdown procedures would preclude this second event. No significant releases are postulated.

\subsubsection{Grout Decontaminated Salt Solutions}

The decontaminated salt solutions would be classified as low-level waste since they are neither high-level waste nor TRU waste. They will be disposed of by grouting and burial in near-surface trenches. These particular releases will be of lower radiological concern; however, the facility and releases are described here because later operations in them could involve higher levels of activity.

\subsubsection{Description of Operation and Facility}

A transportable grout facility will be used to make the grouted waste form by blending grout-forming solids with the liquid waste and pumping the slurry to the disposal site. A schematic of the grout process is shown in Figure 5.7, and the near-surface trench disposal of grout is shown in Figure 5.8.

The grout process would involve two new facilities: 1) the Dry Materials Receiving and Handling Facility, where the grout-forming solids would be blended, and 2) the Transportable Grout Equipment modules where the blended solids would be mixed with liquid waste and the resulting slurry pumped to the disposal site. The second facility is the only one with a radionuclide inventory. Thus, it is the one with potential radiological impact and the only one of interest for our analysis.

The transport grout equipment would consist of transportable modules that would mix blended solids with liquid wastes. The resulting slurry would be pumped into the disposal sites. The transportable grout equipment would include:

- blended solids feed system (for providing solids to the grout mixer)

- grout mixing and pumping system 


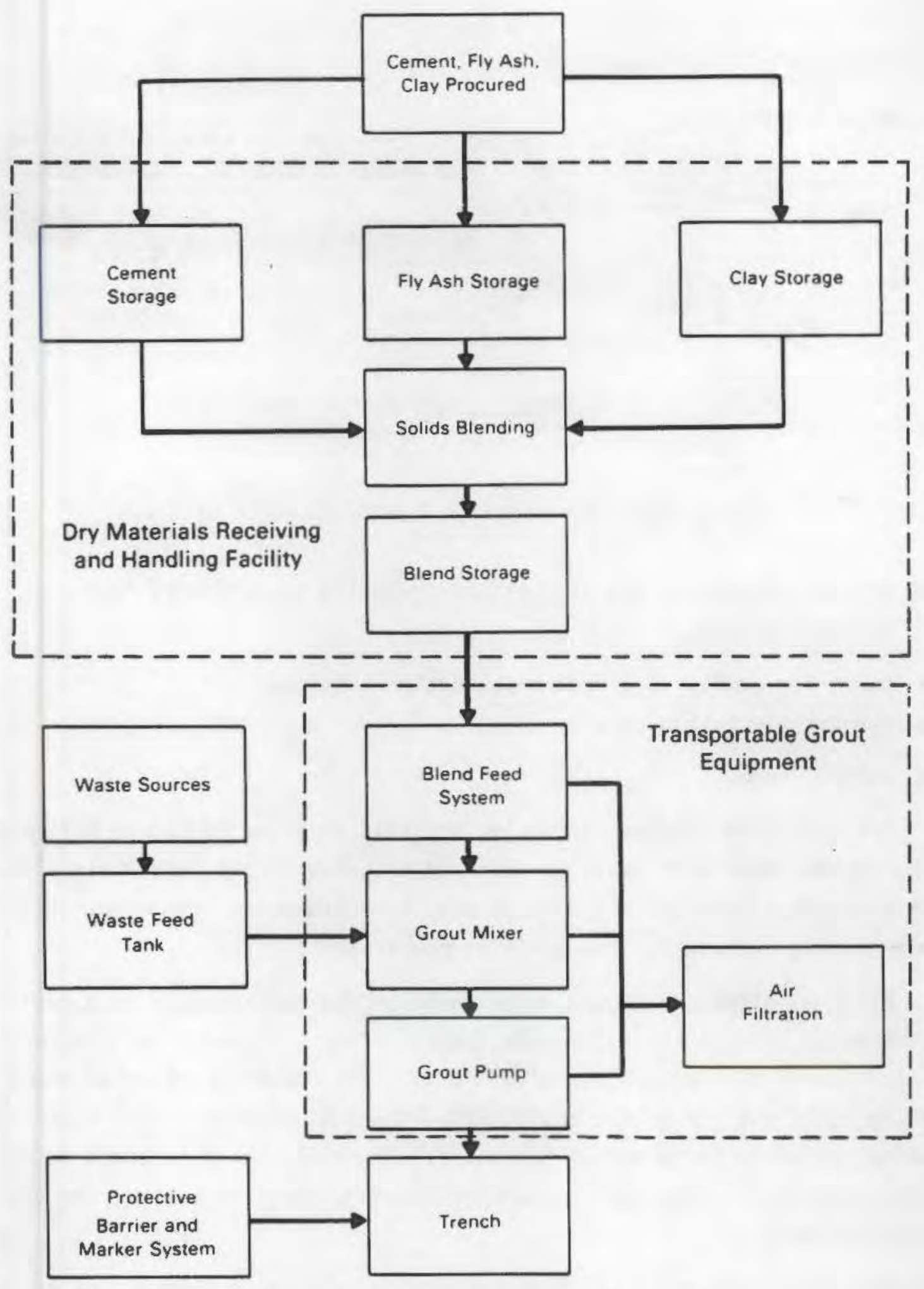

FIGURE 5.7. Schematic of Grout Process 


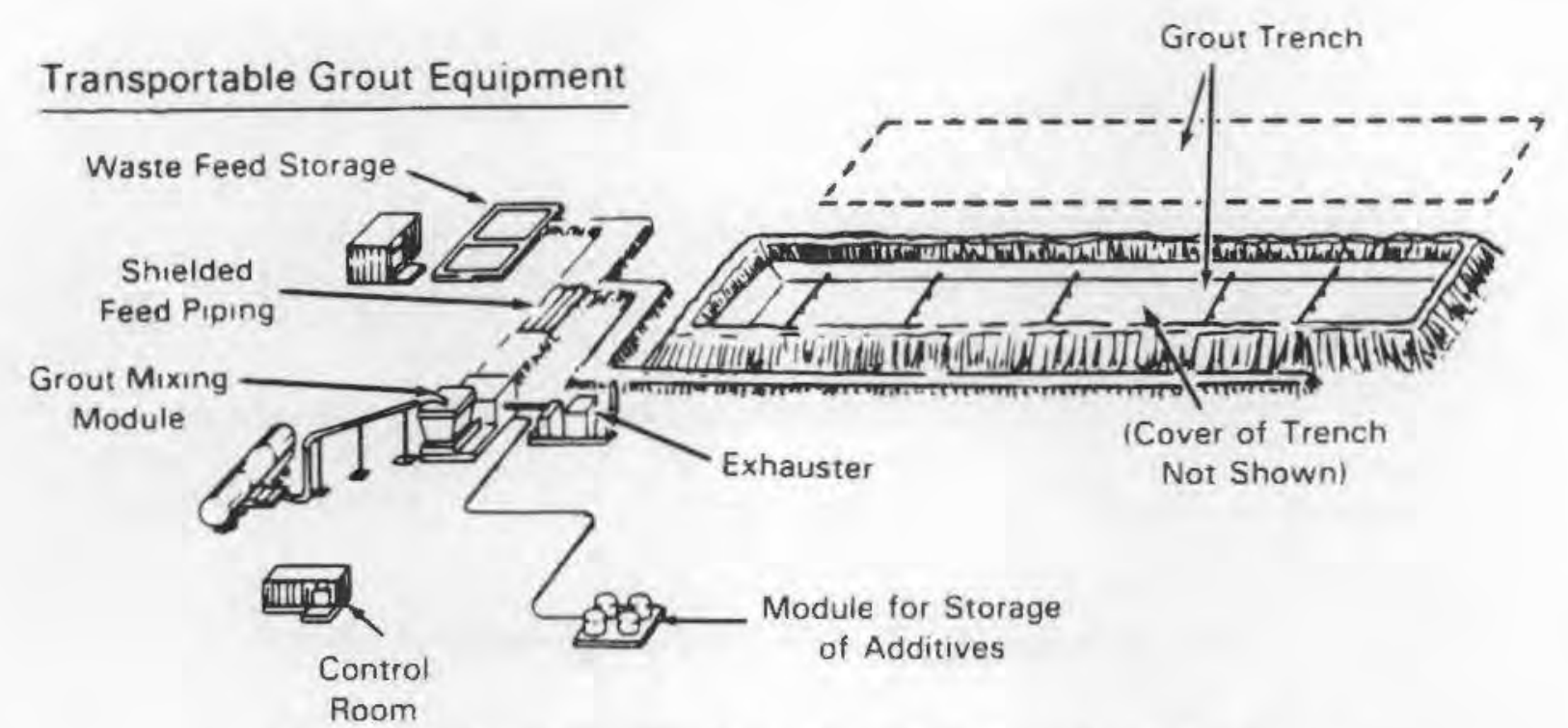

FIGURE 5.8. Near-Surface Trench Disposal of Grout

- off-gas exhausters and filters (for removing contaminants from process off gas)

- tanks for additives and decontamination solutions

- standby electric generator

- control room.

The suggested process for making grout is depicted in Figure 5.7 ; operations in the lower half would involve radionuclide-bearing materials. The operations would involve blending of the dry solids with liquid waste to form a grout slurry, and pumping the grout to the disposal site.

Blended solids and liquid waste would be fed continuously into one end of a continuous grout mixer. The rate, based on waste liquid flow rate, would typically be $1 \mathrm{t}$ of solids per $\mathrm{m}^{3}$ of waste. The rotating action of the mixer paddles would mix the solids and liquids into a homogenous slurry discharged by gravity at the opposite end of the mixer. Chemicals could be added to the mixer and/or waste feed tank to control foaming, grout viscosity, and grouthardening rates.

The grouted slurry would flow by gravity into the intake end of a progressive cavity pump, and then pumped through a pipe to either a plastic-lined 
trench (decontaminated salt), a culvert vault, or a retired underground storage tank. Maximum pumping distance would be $460 \mathrm{~m}$ at a pressure of $350 \mathrm{psi}$. During filling, the trench would be covered to retain moisture.

High-efficiency particulate air filters connected to the mixing/pumping module would be used to protect against the release of airborne contamination by pulling air from contaminated equipment. Continuous air monitoring would be conducted to detect filter failure. Action within the mixing/pumping module would be monitored by television and liquid-level sensors to permit early detection of process problems. Small radioactive spills and leaks that might occur would be contained within the modules. Because of the small spills and leaks, equipment would have to be periodically flushed and decontaminated. Decontamination solutions used to clean up spills and leaks would be mixed with grout formers and similarly disposed of as grout. No details of the facility construction are available.

Wastes could be immobilized in hydraulic cement-based grout in three ways: 1) chemical combination or adsorption with the cement constituents to form hydrated compounds, 2) containment in the pore structure of the grout matrix, and 3) mechanical blending of solid particles by the grout matrix. The wastes associated with each of these methods have not been identified.

\subsubsection{Postulated Upper-Bound Accidents}

The grout process is new and thus is not covered extensively in the 1iterature. For the purposes of this analysis, it is postulated that the salt solution is sprayed from a penetration of the transfer line within the process. A liquid is chosen since less energy is required to subdivide the liquid than the grout, which is viscous. A second consideration in selecting a liquid is that the radionuclides are more concentrated in the liquid. There are typically $1 t$ of solids mixed with a $\mathrm{m}^{3}$ of waste, so the grout dilutes the waste by about one-half.

\subsubsection{Release Estimate for Upper-Bound Event}

Even under conditions for formation of a spray, the quantity of particles less than $10 \mathrm{\mu m}$ is only $0.01 \mathrm{wt} \%$ (Mishima and Ayer 1981). It is therefore assumed that 0.01 wt\% of the liquid released is made airborne. Assuming a 
density for the liquid of $1.3 \mathrm{~g} / \mathrm{cm}^{3}$ and a total flow of $10 \mathrm{~m}^{3}$, a total of $1,300 \mathrm{~g}$ of salt solution is released to the facility. Assuming a filtration system with two stages of high-efficiency particulate air filtration and a transmission factor of $2.5 \times 10^{-7}, 3 \times 10^{-4} \mathrm{~g}$ of salt solution would be released to the atmosphere as listed in Table 5.7 .

\subsubsection{Other Accidents Considered}

Releases from less than upper-bound accidents are discussed below and listed in Table 5.7 .

Salt Solution Tank Leak. As mentioned in previous sections, the release would be analogous to the free-fall spill of a liquid.

Mixer Tank Leak. At worst, the airborne release from this event could approach that for the pressurized release of the salt solution due to the centrifugal force imparted to the liquid by the mixer. The amount of liquid available would be limited by its absorption by the dry components. Thus, it is not anticipated that the airborne release from this event would be as severe as that for the pressurized release.

Grout Spill. This event involves grout, which is more difficult to subdivide than a liquid under the same conditions. Thus, the potential airborne release from this event would be less than that for the liquid.

\subsubsection{Fill Empty Tank}

The residual tank waste (less than $5 \%$ of initial quantities in singleshell tanks and less than $0.05 \%$ in double-shell tanks) and the tanks themselves

\section{TABLE 5.7. Postulated Airborne Releases from Accidents} During Grouting Decontaminated Salt Solutions

\begin{tabular}{|c|c|}
\hline Event & Atmospheric Airborne Release \\
\hline $\begin{array}{l}\text { Pressurized release of } \\
\text { salt solution }\end{array}$ & $3 \times 10^{-4} \mathrm{~g}$ \\
\hline $\begin{array}{l}\text { Salt solution tank } \\
\text { leak }\end{array}$ & Significantly below upper-bound \\
\hline Mixer tank leak & Significantly below upper-bound \\
\hline Grout spill & Significantly below upper-bound \\
\hline
\end{tabular}


would be disposed of in place. The single-shell and double-shell tanks and the annulus of double-shell tanks would be filled with grout, gravel, sand, soil, or other substances to control subsidence in the event of tank structural failure (dome collapse). This operation is called "dome fill" and is described in the Hanford Defense Waste Environmental Impact Statement.

\subsubsection{Description of Operation (No Factlity Indicated)}

The operation is essentially the one described under subsidence control for waste tanks in the Hanford Defense Waste Environmental Impact Statement.

Uniformly graded basalt gravel sized between 1 and $2 \mathrm{~cm}$ has been selected as dome fill material for use in single- and double-shell tanks.

Fill placement would be accomplished with a modified, commercially available centrifugal thrower. This equipment is used extensively for the transfer of granular and small lump materials at seaports and railroad terminals. The operating principle of the equipment is to change the direction of the falling gravel mass, using the kinetic energy of the mass to distribute the material laterally. The downward velocity of the gravel is redirected horizontally when the material is carried through an arc on a high-speed belt (Figure 5.9).
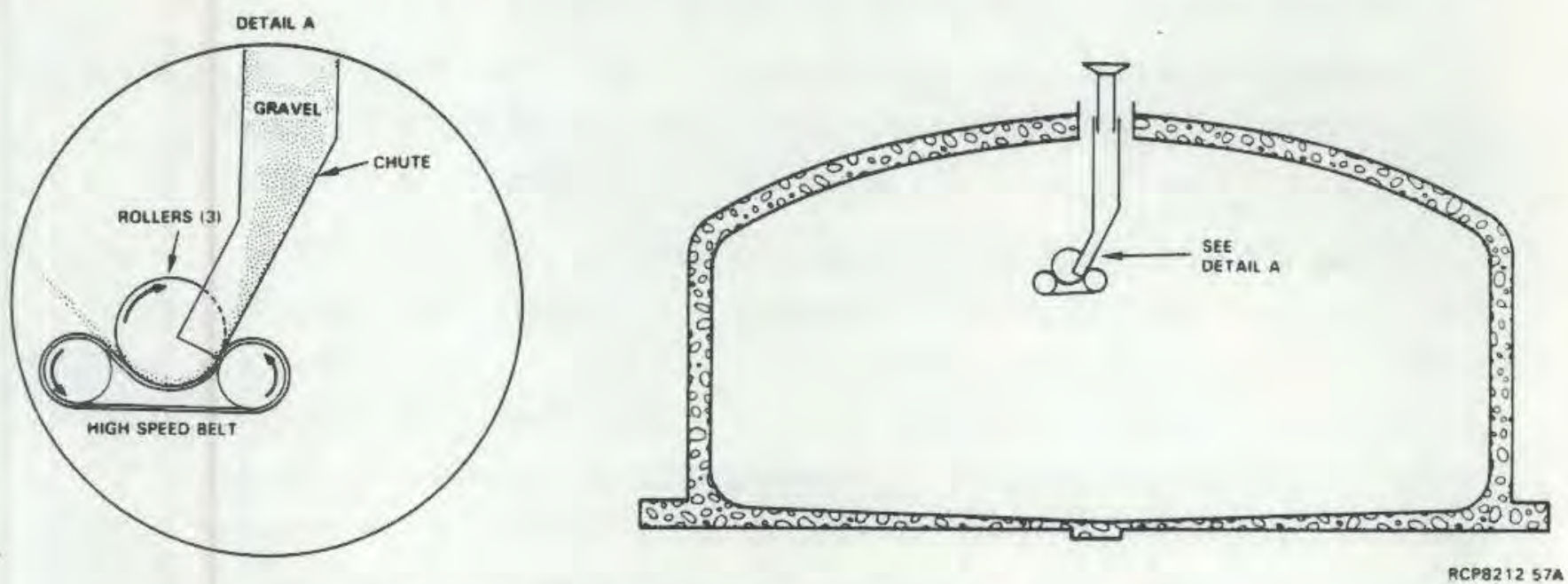

FIGURE 5.9. Centrifugal Thrower for Filling Waste Tanks 
The individual tanks would be maintained slightly below atmospheric pressure for the dome filling process. Ventilation air would be discharged through two high-efficiency particulate air filters to maintain effluent concentrations less than maximum permissible concentrations for discharge to uncontrolled areas. After completion of the fill, operation risers and other penetrations to the tank dome would be sealed with nonradioactive grout.

Porosity in the dome fill material would allow the waste to migrate into the material and enhance gas and vapor release. Waste migration would not raise the existing level above the height of the steel liner in the waste tank.

Individual tanks or whole tank farms would be covered with $1 \mathrm{~m}$ of soil. Contaminated soil, around and under tanks, resulting from past tank leaks is classed as low-level waste. That waste is relatively well fixed in the sedinents and left in place.

\subsubsection{Postulated Upper-Bound Accident}

A dome collapse could be initiated if heavy equipment is inadvertently driven onto the tank. Since the operation is performed in the open, the release would be directly to the atmosphere.

\subsubsection{Release Estimate for Upper-Bound Release Event}

Hayward and Jensen (1980) suggested a $5 \times 10^{-8}$ fractional release from a dome collapse. Rockwell (1980) estimated that $7 \mathrm{~kg}$ of dry saltcake as particles less than $10 \mu \mathrm{m}$ in diameter could be released in a dome collapse.

Since the tank contains only residual material, up to $5 \%$ of the original quantity, the $7 \mathrm{~kg}$ release will be lowered correspondingly. Therefore, the release calculates to $350 \mathrm{~g}$ as 1 isted in Table 5.8 . This is a very conservative approach because much of the residual material could be hardened, fixed on the walls, and not susceptible to becoming airborne. In both cases (tank completely or partially full) the dome is being filled with inert material and the waste will conceivably be covered with this material; therefore, severity of the release will be mitigated. The upper-bound accident would occur as the operations begin before any fill is delivered to the tank. 
TABLE 5.8. Postulated Airborne Releases from Accidents During Filling of Empty Tank

\begin{tabular}{|c|c|}
\hline Event & Atmospheric Airborne Release \\
\hline Dome collapse & $\begin{array}{l}350 g^{(a)} \\
5 \times 10^{-8} \text { fraction }(b,)\end{array}$ \\
\hline $\begin{array}{l}\text { Loss of filtration } \\
\text { lst stage } \\
\text { Both stages }\end{array}$ & $\begin{array}{ll}5 \times 10^{-6} & \mathrm{~g} / \mathrm{m}^{3} \\
1 \times 10^{-2} \mathrm{~g} / \mathrm{m}^{3}\end{array}$ \\
\hline $\begin{array}{l}\text { Loss of services or } \\
\text { power }\end{array}$ & No significant release \\
\hline Equipment failure & No significant release \\
\hline
\end{tabular}

(a) Based on Rockwell (1980).

(b) Hayward and Jensen (1980).

\subsubsection{Other Accidents Considered}

Additional accidents are developed in the following section, and releases are included in Table 5.8 .

Loss of Filtration. This event could occur when equipment used in the dome-filling operation hits the fitter and dislodges it. Any afrflow (rate unknown) would therefore be unfiltered. It might be assumed, as in the dome collapse, that much of the airborne material would be inert rather than radioactive. If the accident happened before the dome filling began, the air in the dome would contain low levels of contanination. Any required safety systems could shut down the airflow. Therefore, these releases are postulated to be lower than in a dome collapse.

Loss of Services or Power. This would shut down the operation, and thus no releases would be envisioned for this event.

Equipment Failure. This event is not seen as leading to releases. Equipment is located outside the tank, radioactive materials inside. Operations would merely be shut down. 


\subsection{FUTURE TAMK WASTE}

Processing of future wank wastes would be integrated with that of existing waste. Insofar as practicable, all newly and future-generated high-level waste would be disposed of in a geologic repository. Many of the operations are the same as for existing tank wastes; therefore, the reader is directed to those sections when appropriate.

\subsubsection{Retrieval}

These wastes are stored in double-shell tanks, and the operation used wil be hydraulic retrieval. Therefore the operation, facility, upper-bound accident, release estimates, and other accidents considered will be the same as those discussed in Section 5.1 .2 and listed in Table 5.3.

\subsubsection{Solid/Liquid Separation and strontium, cesium, Technetium and TRU Removal}

These operations will share the same facility and operations as the existing tank waste. Therefore the operation, facility, upper-bound accident, release estimates, and other accidents considered will be the same as those described in Section 5.1 .3 and listed in Tables 5.4 . and 5.5 .

\section{2 .3 Grout Decontaminated Liquid}

The partially decontaminated liquid would be converted to grout, along with other wastes. Grout would be disposed of in shallow trenches. Thus these operations are the sane as those for existing tank waste and the operation and facflity, upper-bound accident, release estimate, and other accidents considered are the same as those for existing tank wasta as described in Section 5.1 .5 and listed in Table 5.7.

\section{2 .4 Vitrification}

Future tank waste will be immobilized in a large vitrification facility operated in conjunction with the sludge washing and solid/liquid separation radionuclide renoval facflity. Therefore, the operations wll be the same as those in section 5.1.4, with the same uppermbund accident, release estimates, and other accidents considered. These are listed in Table 5.6. 


\subsubsection{Fill Empty Tanks}

Future tank waste would be in double-shell tanks. The anticipated residual waste would be less than $0.05 \%$ of the initial quantity, thus reducing the magnitude of any potential release. The operations, upperbound accident, and other accidents considered would be the sane as described in Section 5.1.6. In that section the postulated dome collapse accident had a $350 \mathrm{-g}$ estimated release, based on a $7 \mathrm{~kg}$ release from a full tank. Here the release is $0.05 \%$ of that from a full tank for a total of $3.5 \mathrm{~g}$. This release is lower than that estimated in Section 5.1.6.3, since there is less residual waste in this tank. The other releases listed in Table 5.8 apply here.

\subsection{STRONTIUM AND CESIUM CAPSULES}

Strontium and cesium capsules (illustrated in Figure 4.1 ) would be stored in the Waste Encapsulation and Storage Facility until 1995, then removed for geologic disposal. The other operation discussed below is packaging the capsules.

\subsubsection{Removal of Capsules from Hater Basin}

Strontium and cesium capsules would be stored in water-fifled basins until the necessary modifications were made to the waste encapsulation and storage facility to allow overpacking. During the storage period, the capsules and basins would be periodically inspected and maintained as necessary. Storage of capsules at the facility is in an active mode that requires cooling water, makeup water, ventilation and maintenance of facility operating systems.

\subsubsection{Description of Operation and Facility}

Neither the waste encapsulation and storage facility, nor its equipment is described in the Hanford Defense Waste Environmental Impact Statement, nor are details of the capsule retrieval systen. These are assumed to be those now in place and described by Braden et al. (1971) in the Safety Analys is Report for that facility. The facility contains a storage pool area, and a crane is available and used to remove cover blocks and capsules. 
The oparation and equipment design and usage are assuned in keeping with sound, prudent nuclear practices especially in the area of engineered safety systens such as the ventilation and exhaust system.

\section{3 .1 .2 Postulated Upper-Bound Accident}

The uppermbound airborne release event postulated is a rupture of the capsule. Waste canisters can be breached before they are encapsulated if they are dropped in handing operations (Hayward and Jensen 1980). Completely encapsulated canisters will not rupture even they are dropped onto concrete from helghts up to 6 an. Encapsulated canisters could not be ruptured when hit by a falling, heavy object such as a cell cover. However, the capsules may be stored for an extended period of time and could potentially deteriorate due to heated storage in water. Glass, which is the material contained in the hayward and Jensen study, provides greater support for the casing than efther the strontium fluoride or ceslum chloride (salt forms) addressed in this study. Therefore, the capsule is assumed to rupture upon inpact after a drop, and the material contained within the capsule is subdivided. The fraction subdivided and made alrborne in the respirable size range is not avallable in the published literature. Thus, the internal pressure generated within the capsule required to rupture it is assumed to be high and the particulates produced are correspondingly fine *

Loss of basin cooling water resulting in the overheating of the cestum and strontiun capsules was not considered as the upper-bound accident for this operation for the following reasons: 1) the basin is designed to withstand the drop of a capsule, 2) if the basin suffers a leak during normal storage, the leak would be slow and detected before significant effect since the facility is continually monitored, and 3) catastrophic loss of basin water is associated with severe natural phenomena (e.g., earthquakes) which are covered in another section.

\subsubsection{Release Estimated for Upper-Bound Event}

A value of approximately 1 was experfmentally measured for less than 10 w a erodynamic equivalent dianeter alrborne fraction of a fine depleted uranium doxide powder relexsed at 50 psig pressure (Sutter 1983) and this 
experimental value is applied. Since it is postulated that this event occurs within a nuclear-grade facility with a filtration system that has two stages of high-efficiency particulate air filters, the respirable fraction released to the atmosphere is conservatively estimated as $2.5 \times 10^{-9}$ of the source. Theoretic density of the salt forms are 3.988 and $4.24 \mathrm{~g} / \mathrm{cm}^{3}$ and the capsule contents are compacted to $75 \%$ of the theoretic density, $503 \mathrm{~g} / \mathrm{cm}^{3}$ is considered a good value to use for the denstty of the radioactive material. The mass of the $7.42 \mathrm{~cm}^{3}$ source is calculated to be $2.2 \times 10^{3} \mathrm{~g}$, the respirable airborne fraction is $2.2 \times 10^{1} \mathrm{~g}$ and the atmospheric release is calculated to be $5.5 \times 10^{-6} \mathrm{~g}$. The release is 1 isted in Table 5.9 .

\subsubsection{Other Accidents Considered}

Other accidents could occur, but have lower releases as listed in Table 5.9.

Capsule Drop in Basin. The impact suffered from the capsules striking water will be significantly less than the impact of a cover block; therefore, it is estimated that the consequences will be much less.

TABLE 5.9. Postulated Airborne Releases from Accidents During Capsule Recovery

\begin{tabular}{ll}
\multicolumn{1}{c}{ Event } & Atmospheric Airborne Release \\
\hline $\begin{array}{l}\text { Capsule rupture } \\
\text { Capsule drop in basin }\end{array}$ & $5.5 \times 10^{-6} \mathrm{~g}$ \\
$\begin{array}{l}\text { Hydrogen accumulation } \\
\text { and explosion }\end{array}$ & $1 \times 10^{-15}$ fraction (a) \\
$\begin{array}{l}\text { Loss of filtration } \\
\text { lst stage } \\
\text { Both stages }\end{array}$ & $5 \times 10^{-6} \mathrm{~g} / \mathrm{m}^{3}$ \\
Fire & $1 \times 10^{-2} \mathrm{~g} / \mathrm{m}^{3}$ \\
Capsule failure in basin & No significant release \\
Loss of services or power & No significant release
\end{tabular}

(a) Richardson (1980). 
Hydrogen Accumulation and Explosion. Hydrogen generated by the radiolysis of water in the basin could accumulate if ventilation flow through the area were lost for a lang period of time. The rate of hydrogen production is depenm dent on the radiation leve $\%$, which is dependent upon the for the concentrated cesium and strantium in the capsules. It is not felt that there is a great possfollity of accumulating levels of hydrogen that could result in an exploston with significant damage to the building, much less to the capsules stored under many feet of water.

Loss of filtration. Loss of filtration without loss of flow would result in the release of the material normally present in the facility, since the areas around the water-filled basin are operating areas and would be at a radiation level safe for personnel, the consequences of such an occurrence are low.

Fire. Due to the presence of combustible materials (plastic - bags, sheeting and equipment; cellulosics - clothing, paper, ete.; and lubricating oils and greases) in the factlity, the possibflity of a fire cannot be ignored. The capsules are made of highly resistant metais, and high temperatures for long periods would be required to result in high enough internal pressures to cause rupturing. The quantity of conbustibles would linit the extent of the fire, so no significant airborne release of the contained radionuclides is postulated.

Capsule Fajlure in Basin. Since storage is an active process in which the capsules and storage basin water are periodically checked, failure of the capm sules in the water-filled basin is not considered to be a likely event and remedial measures (including decontamination of both the basin water and capsules) would be quickly implemented,

Loss of Services or Power. In this aperation, loss of services or powes would result in cessation of operations or loss of flow. Neither consequence is viewed as a significant release nechanism. 


\subsubsection{Capsule Packaging}

The capsule packaging process is described in Appendix $B$ of the Hanford Defense Waste Environmental Impact Statement.

\section{3 .2 .1 Description of Operation and Factilty}

The capsule packaging process is visualized as having a throughput rate of one canister per day. The strontium and cesium capsules would be placed in racks and inserted into canisters made from $0.3-m$-outside dianeter carbon steel pipe about $2.7 \mathrm{~m}$ long with end plates. The canisters would be sealed, inspected, and surveyed for radioactive surface contamination. An ajr-cooled vault would provide lag storage space for the sealed canisters before their transfer to the drywell storage facility or a geologic repository. The following key equipment pieces would be operated in essentially the order listed to load one canister:

1. Seven-capsule holding vault

2. Three-station load/weld machine

- At the "exit" station, a canister containing an empty capsule rack would be placed on the machine.

- At the "load" station, an actuator, arm, and grapple would connect to the capsule rack and withdraw it vertically a distance of approximately 2 in from the canister. Capsules, handled by conventional hot cell mantpulators, would be loaded onto the rack as it was lowered back into the canister.

- At the "weld" station, a lid would be placed on the canister by manipulator or in-cell crane. A rotating weld head would make the weld closure.

3. Hellum leak test unit

4. Ultrasonic weld penetration test unit

5. Electropolishing decontanination tank 
6. Canister storage pods: an array of 12 steel sleeves $10.38-m$ instak diameter, with lids) that would penetrate the cell floor. A wind tunnel below would provide forced or natural convection dir cooling.

The number of capsules loaded into a canister would vary according to heat dissipation capabilities of the storage medium (basalt, salt, or near-surface soil) and on themal Ifmitations of the capsule materials thenselves.

The capsule packaging facillty is envisioned as series of three hot cells (aach 4.9 mide by $3 \mathrm{~m}, 14 \mathrm{~m}$, and $7 \mathrm{~m}$ long) housed in an overall facil ity that would be $43 \mathrm{~m} \mathrm{long.} 14 \mathrm{~m}$ high, and that would occupy approxinately $1100 \mathrm{~m}^{2}$. High-density concrete shielding walls of the hot cells would be $-0.9 \mathrm{~m} \mathrm{thick}$, and would have eight viewing windows and four manipulator pairs.

\section{3 .2 .2 Postulated UppermBound Accident}

The literature reviewed (Dof 1982; Hayward and Jensen 1980, Rtchardson 1980) stated that encapsulated waste canisters cannot be failed unless infacted by a falling, heavy object such as a cell cover. Whether this applies to capsules that have been stored under water for long perfods of time js not known. It is postulated that a capsule fails by impact with the machinery used in handling such as a crane head and releases a portion of its contents to the cell atmosphere.

\subsubsection{Release Estimate for Upger-Bound Event}

The maximum airborne release to the envitons is a $3 \times 10^{-10}$ fraction of the source based on values found in the literature (00E 1982). The filter transmission $\$ 52.5 \times 10^{-7}$; thus, the fractional release (back calculated) from the source is $1.2 \times 10^{-3}$. This is the failure of a single capsule; $2.64 \mathrm{~g}$ is airborne in the cell and $6.6 \times 10^{-7} \mathrm{~g}$ is released to the atmosphere. This value is lower than that calculated in Section 5.3 .1 .3 , but here only a portion of the capsule is involved in the release. The release is listed in Table 5.10 .

\subsubsection{Qther Accidents Considered}

Releases from the less than upper-bound accidents are developed below and listed in Table 5.10 . 
TABLE 5.10. Postulated Airborne Releases from Accidents During Capsule Packaging

\begin{tabular}{|c|c|}
\hline Event & Atmospheric Airborne Release \\
\hline $\begin{array}{l}\text { Machinery impacts } \\
\text { capsule }\end{array}$ & $6.6 \times 10^{-7} \mathrm{~g}$ \\
\hline Fire & Significantly below upper-bound \\
\hline $\begin{array}{l}\text { Loss of of } f \text {-gas } \\
\text { exhaust system } \\
\text { 1st stage } \\
\text { Both stages }\end{array}$ & $\begin{array}{l}5 \times 10^{-6} \mathrm{~g} / \mathrm{m}^{3} \\
1 \times 10^{-2} \mathrm{~g} / \mathrm{m}^{3}\end{array}$ \\
\hline
\end{tabular}

Fire. A fire in the facility is possible because of the combustibles normally found in such facilities. Its radiological consequences will be limited since the fire would have little effect upon the encapsulated radioactive materials.

Loss of off-Gas/Exhaust System. Loss of filtration without loss of ventilation flow would release the material airborne in the facility to the atmosphere around the facility. The capsules handled in this operation have been checked for contamination and cleaned several times before this operation. The operation does not appear to be dusty; there would be minimal airborne material. Therefore, it is estimated that little radioactive material would be released for this occurrence.

\subsection{TRU-CONTAMINATED SOIL}

A TRU-contaminated soil site is one in which liquids (usually aqueous solutions) have been intentionally or inadvertently released to the soil. These sites consist of cribs, trenches, ponds, ditches, reverse wells, French drains, and unplanned releases.

\subsubsection{Mechanical Retrieval of TRU-Contaminated Soil}

The facility shown in Figure 5.10 and described in the Hanford Defense Waste Environmental Impact Statement will be used for recovery of both TRUcontaminated soil and TRU solid waste sites. 

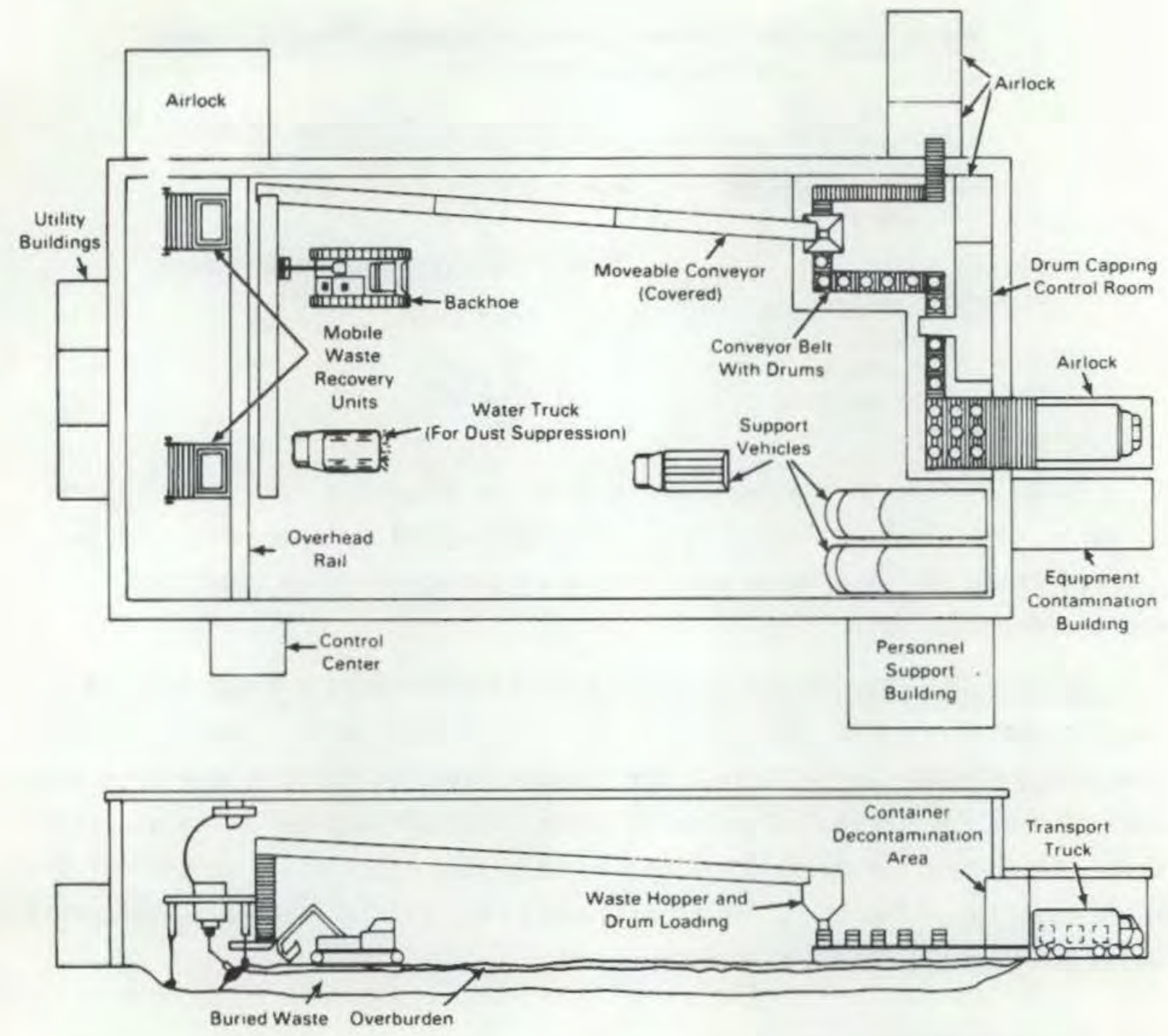

FIGURE 5.10. Mechanical Retrieval of Wastes from Soil or Solid Waste Sites

\subsubsection{Description of Operation and Facility}

Some of the contaminated soil sites are small, and the facility is large, so the facility is assumed to be used on soil sites as appropriate. The approximate building dimensions would be $46 \mathrm{~m}$ wide by $92 \mathrm{~m}$ long and $12.5 \mathrm{~m}$ high. This calculates to a $5.3 \times 10^{4} \mathrm{~m}^{3}$ volume.

Electrically operated equipment would be used for retrieval of contaminated soil. Some equipment would be battery operated, while other equipment would be connected by cables to the building power supply. Equipment used 
during soil retrieval would include waste retrievers, container haulers, dust precipitators, and heavy-duty backhoes.

The recovery building, support equipment, and recovery equipment would be thoroughly tested before the entry pit and radioactive waste were excavated. Dust within the pit would be controlled by spraying the working face of the pit. with dust suppressants and operating dust precipitators. Mobile waste retrievers would excavate the soil and place it in containers. Filled containers would be checked for radiation levels and TRU content, decontaminated, and moved through an airlock into a special transportation trailer.

The retrieval building would be maintained slightly below atmospheric pressure, and air discharged through two stages of high-efficiency particulate air filters.

\subsubsection{Postulated Upper-Bound Accident}

The maximum release event postulated is an explosion that would breach a weak portion of the facility and provide a significant unfiltered pathway to the atmosphere for the particulate material generated by the event. An explosion could result from battery-generated hydrogen buildup in a confined volume, possibly occurring during off hours when the batteries were being recharged. It is assumed that all batteries would be brought to one portion of the building for this operation. Hydrogen produced by the recharging operation would accumulate with minimal ventilation. An explosion could be initiated by static electricity or by a match lighted in the vicinity of the hydrogen. No spray system would be working at the time of the event. The waste is assumed to be in piles.

\subsubsection{Release Estimate for Upper-Bound Event}

This event is postulated to breach the facility and generate a $1000-\mathrm{m}^{3}$ cloud with total mass airborne of $5 \mathrm{~kg}$. It was assumed that the airborne mass might be as great as the maximum found in dust devils, $5 \mathrm{~g} / \mathrm{m}^{3}$ (Sinclair 1976). The waste airborne would be fragments of contaminated soil. Only a portion of the airborne material would be in the respirable size of concern less than $10 \mu m$ aerodynamic equivalent diameter. Sutter (1980) measured the size of some Hanford soil and determined that this respirable fraction was 
$0.088 \%$. Using this value to estimate the respirable fraction reduces the release of concern to $5 \mathrm{~g}$, as listed in Table 5.11 .

\subsubsection{Other Accidents Considered}

A variety of accidents were considered before selecting the upper-bound event. These are developed below and listed in Table 5.11.

Spills. Spills of contaminated soil could occur. For one incident of this kind, a fractional release of $1 \times 10^{-4}$ was assumed (OOE 1979). Sutter, Johnston and Mishima (1981) measured airborne releases from powders spilled in static air and found the maximum release fraction to be $0.12 \%$. These values show the spill to have a low potential for release.

Facility fire. A facility fire during retrieval would be unlikely since the equipment is battery-operated so there is no fuel source. There would be insufficient combustible material in the structure to support a fire. An external fire such as a range fire igniting the facility was considered an unlikely event because of the sparseness of vegetation in the work areas.

Filter Failure. High-efficiency particulate air filter failure or building leak are similar events. They could occur because of human error or equipment failure. Water sprays would mitigate the event. Murphy and Holter (1980) identified the air dust loading at $1.0 \mathrm{mg} / \mathrm{m}^{3}$ and the calculated release for filter failure was a $1.2 \times 10^{-6}$ fraction, a building leak three orders of magnitude less. They identified the frequency of filter failure at less than $1.0 \times 10^{-5}$ per year, the building leak at greater than $1.0 \times 10^{-9}$ per year.

TABLE 5.11. Postulated Airborne Releases from Accidents During During Mechanical Retrieval of TRU-Contaminated Soil

\begin{tabular}{|c|c|}
\hline Event & Atmospheric Airborne Release \\
\hline Explosion & $5 \mathrm{~g}$ \\
\hline Spills & $1.2 \times 10^{-3}$ fraction \\
\hline Facility fire & No significant release \\
\hline Filter failure & \\
\hline 1st stage & $5 \times 10^{-6} \mathrm{~g} / \mathrm{m}^{3}$ \\
\hline Both stages & $1.2 \times 10^{-2} \mathrm{~g} / \mathrm{m}^{3}$ \\
\hline
\end{tabular}


Based on aerosol behavior (ORNL 1970) $10 \mathrm{mg} / \mathrm{m}^{3}$ is assumed to be the maximum concentration of quasi-stable aerosol in the facility. Releases per cubic meter are listed in Table 5.11.

\subsubsection{Processing}

TRU-contaminated soil would be sent to a waste processing facility to be treated to form a chemically inert, physically stable, basalt-like slag that meets repository requirements for immobilized waste forms.

\subsubsection{Description of Operation and Facility}

The retrieved contaminated soil would be transferred from transport trucks to a receiving airlock at the processing facility. The waste processing facility would house the equipment; ventilation air would be discharged through high-efficiency particulate air filters. All operations in the facility, from airlock waste entry to packaging of the output product, would be remotely controlled. After passing through the airlock, each container would be weighed, assayed, examined by $x-r a y$, and stored for further processing.

The processes for converting the waste to a stable product have not been selected. One possible concept used for analytical purposes, a vertical furnace with two main components, a gasifier and a secondary combustion chamber, would constitute a Slagging Pyrolysis Incineration unit as shown in Figure 5.11. The gasifier has three zones: drying, pyrolysis, and combustion. A secondary chamber completes combustion of the off gas, which is then cooled and filtered. Slag would be poured into molds, assayed, and prepared for transport to the geologic repository.

\subsubsection{Postulated Upper-Bound Accident}

A fire and deflagration involving contaminated materials in the fuel-rich gasifier is the postulated upper-bound airborne release event. This is suggested since explosions can result from the ignition of clouds of fine wood or coal dusts, diesel oil mists, or rich fuel mixtures (Orr 1966). Process ma1function allows carbon monoxide to reach the incinerator drying section where it reacts rapidly with the air introduced with the waste. The mixture deflagrates, resulting in failure of the upper portion of the gasifier due to overpressurization. The concrete structure is breached in the explosion. 


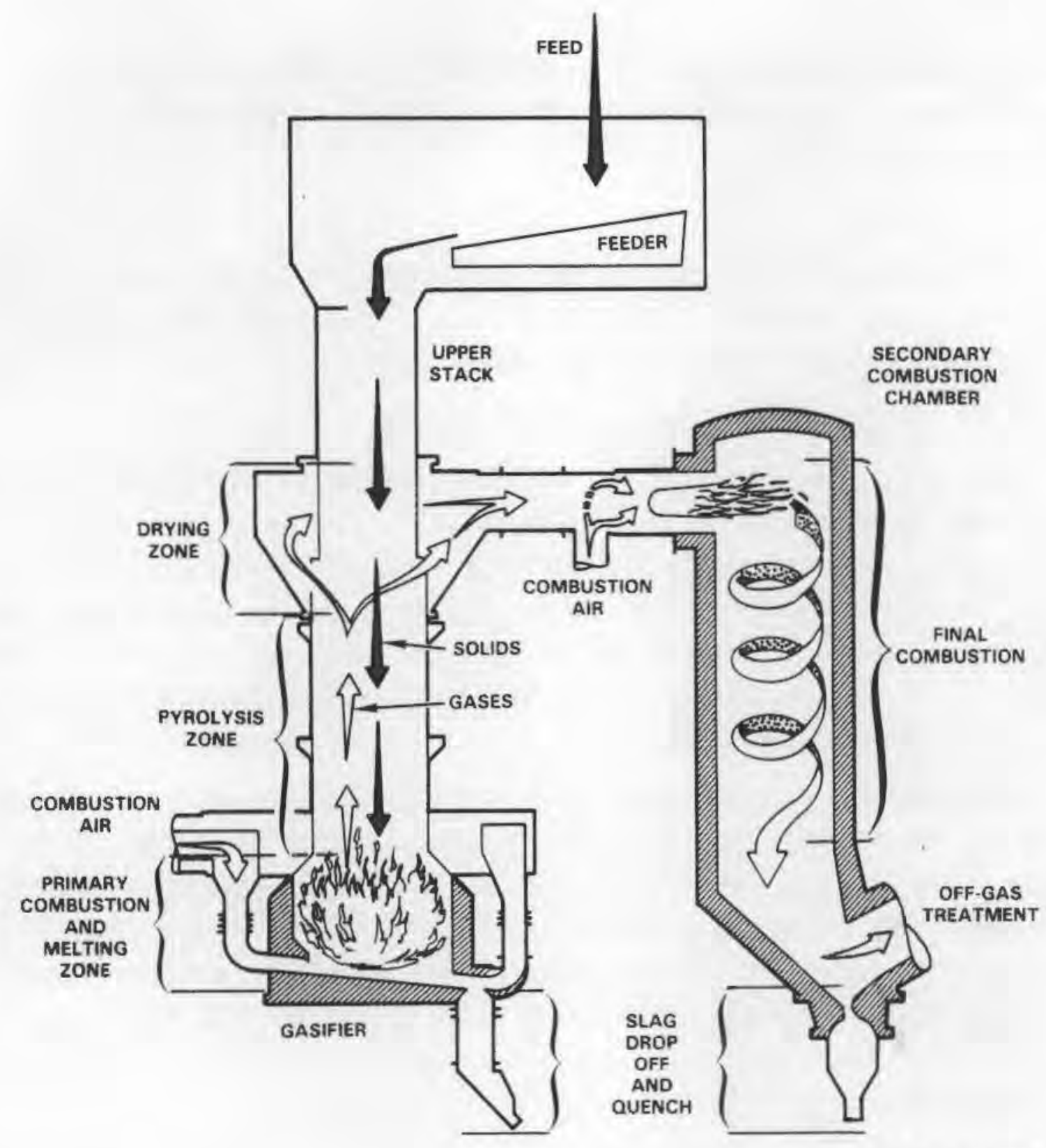

RCP8109.376

FIGURE 5.11. Slagging Pyrolysis Incineration Gasifier and Combustion Chamber

\subsubsection{Release Estimate for Upper-Bound Event}

A $1000 \mathrm{~m}^{3}$ cloud filled with radioactive particles is assumed to be generated by the explosion. Mishima (1975) estimated that explosion generated clouds can attain a quasi-stable concentration of particles of $100 \mathrm{mg} / \mathrm{m}^{3}$. The particles in the cloud are considered to have a size distribution typical of 
particles in the secondary combustion chamber off gas with $50 \%$ in the fraction $10 \mu \mathrm{m}$ aerodynamic equivalent diameter and less as suggested by the work of Christian et a1. (1978) and Kirstein et al. (1979). The total release of respirable particles is $50 \mathrm{~g}$. Only a portion of the release will be TRUcontaminated soil. However, for purposes of this analysis it is all assumed contaminated. Since the facility is breached, the release is atmospheric, as listed in Table 5.12 .

\subsubsection{Other Accidents Considered}

Other accidents were considered before the upper-bound release was selected. They are developed in the following sections and listed in Table 5.12 .

Criticality. A criticality would not be considered a credible accident because of administrative procedures. These could include screening waste for fissile content, introducing a small concentration of neutron absorbent to the feed, and using neutron detectors in the facility, particularly in the drying, pyrolysis, and slag regions (Close, Booth and Caldwell 1981). Criticality therefore would require multiple failure of administrative and system controls accompanied by a highly unusual fuel-fissile concentration or an accumulation of fissile material (Kirstein et al. 1979).

Spill. A slag spill could occur as the waste is cast. The release would be less than that anticipated for a powder spil1, and is assumed to be similar to that from a 1iquid, $0.01 \%$ (Sutter, Johnston and Mishima 1981). If the amount spilled is equivalent to the amount in a drum, about $56 \mathrm{~g}$ could be airborne in the facility for an atmospheric release of $1.4 \times 10^{-5} \mathrm{~g}$. A release after the waste is cast could have lower releases, a $1 \times 10^{-6}$ fraction.

TABLE 5.12. Postulated Airborne Releases from Accidents During Slagging Pyrolysis Incineration of TRU-Contaminated Soil

\begin{tabular}{|c|c|}
\hline Event & Atmospheric Airborne Release \\
\hline Explosion & $50 \mathrm{~g}$ \\
\hline Criticality & No significant release \\
\hline Spill & $1.4 \times 10^{-5} \mathrm{~g}$ \\
\hline
\end{tabular}


5.5 PRE-1970 TRU SOLID WASTE

Buried TRU solid waste would be retrieved and processed using procedures similar to those proposed for use at TRU-contaminated soil sites.

\subsubsection{Mechanical Retrieval of Pre-1970 TRU Solid Waste}

Retrieval procedures would be similar to those described above (Section 5.4.1), with some additions because solid wastes are involved. Only additional operations are discussed.

\subsubsection{Description of Operation and Facility}

Additional equipment (beyond that used for TRU-contaminated soil) required for solid waste includes waste sizers that could perform sawing, shearing, hammering, and bending operations. If the size could not be reduced, a heavyduty backhoe would be used to secure the oversize waste for special handling.

\subsubsection{Postulated Upper-Bound Accident}

This was described in Section 5.4.1.2.

\subsubsection{Release Estimate for Upper-Bound Event}

Since this is the same event as for TRU-contaminated soil, the estimate method is the same.

\subsubsection{Other Accidents Considered}

The other accidents considered are the same as those in Section 5.1.4, but since solid material can be included, there are other potential accidents as 1isted below. All releases are also listed in Table 5.13.

Leaks. A leak from a breach drum is an accident that could be considered. During waste retrieval operations at Idaho National Engineering Laboratory this type of accident occurred. During one period, $70 \%$ of the drums retrieved from one pit and all from another were breached. Free liquids leaked from $9 \%$ of the drum and $5 \%$ were externally contaminated (McKinley and Mckinney 1978). In one case several liters of contaminated liquid leaked from a deteriorated container. Eventually $8000 \mathrm{~cm}^{2}$ of soil surface was contaminated and exhibited mobility requiring an asphalt spray to fix the contamination to the soil. No activity passed through the high-efficiency particulate air filters 
subsequent to this event (Harness and McKinney 1977). This experience indicates that little or no radioactive material would be released from the building as a result of a leak.

Pressurized Release. A pressurized release in the preparation area could occur if gases had built up in a drum. Various sources of gas are possible (e.g. radiolysis, decay of materials, spontaneous oxidation, etc.). The reactions which result in the loss of integrity of the vessel may also vary, but the forces that result in the airborne dispersion of particles are limited by the failure pressure of the container. The failure pressure of the container is a function of many characteristics of the container. The volume of gas increase that results in that pressure can also be small (a pressure of 50 psig is only a three-fold increase in the free volume of a container). A failure pressure of 50 psig was assumed to be conservative for 55-gallon drums buried for extended periods. At 50 psi, the release factor is $1 \%$ of the respirable particles, less than $10 \mu \mathrm{m}$ aerodynamic equivalent diameter in diameter. The filters should not be damaged by this release.

TABLE 5.13. Postulated Airborne Releases from Accidents During Mechanical Retrieval of Pre-1970 TRU Solid Waste

\begin{tabular}{ll}
\multicolumn{1}{c}{ Event } & \multicolumn{1}{c}{ Atmospheric Airborne Release } \\
\cline { 1 - 2 } $\begin{array}{l}\text { Explosion } \\
\text { Filter failure }\end{array}$ & $5 \mathrm{~g}$ \\
lst stage & $5 \times 10^{-6} \mathrm{~g} / \mathrm{m}^{3}$ \\
Both stages & $1.2 \times 10^{-2} \mathrm{~g} / \mathrm{m}^{3}$ \\
Spills (powder) & $1.2 \times 10^{-3}$ fractional release \\
Facility fire & $1.3 \times 10^{-10}$ fractional release \\
Liquid leaks & Significantly below upper-bound \\
$\begin{array}{l}\text { Pressurized release } \\
\text { Spread of surface }\end{array}$ & $1 \times 10^{-2}$ fraction \\
Contamination & Significantly below upper-bound \\
Container fire & $1.3 \times 10^{-13}$
\end{tabular}


Spread of Surface Contamination. This release could occur when contaminated containers are recovered. It should be anticipated, and could possibly even be considered a routine release. The release would be at a low level and removed by the high-efficiency particulate air filters.

Fire. A fire in a waste container could occur if nitric acid leaked onto cellulosic material. This could lead to a possible detonation at slightly elevated temperatures due to self ignition (Mulkin 1975). The release fraction for combustibles contaminated with powder could be $5 \times 10^{-4}$. High-efficiency particulate air filtration would prevent a significant amount of radionuclides from entering the atmosphere, with the atmospheric fractional release $1.3 \times$ $10^{-10}$.

\subsubsection{Sorting and Related Operations}

The solid waste could require steps beyond those described for soil (5.4.2.1).

\subsubsection{Description of Operation and Facility}

Solid waste first would be sorted and sized. Any materials requiring special handling would be separated from the waste stream and treated as needed. Large items would be sized by crushing, shredding, or flattening suitable for incineration. After the waste was blended to achieve uniformity, it would be fed to a processing unit.

\subsubsection{Postulated Upper-Bound Accident}

A pressurized release from a ruptured container is postulated. The accidents could be the result of radiolytic gases building up within a drum.

\subsubsection{Release Estimate for Upper-Bound Event}

Based on experimental studies (Sutter 1983), a pressurized release of $1 \%$ of the contents is estimated becoming airborne as less than $10 \mu \mathrm{m}$ aerodynainic equivalent diameter particles. This assumes the drum ruptures at 50 psi. Assuming a $210 \mathrm{~L}$ volume and waste density $0.96 \mathrm{~g} / \mathrm{cm}^{3}$, the drum could contain as much as $2 \times 10^{5} \mathrm{~g}$ of waste, thus $2 \times 10^{3} \mathrm{~g}$ could be airborne. The release will challenge two high-efficiency particulate air filters and $5 \times 10^{-4} \mathrm{~g}$ is the atmospheric release listed in Table 5.14. 
TABLE 5.14. Postulated Airborne Releases from Accidents During Sorting and Related Operations with Pre-1970 Solid Waste

\begin{tabular}{lll}
\multicolumn{1}{c}{ Event } & \multicolumn{1}{c}{ Atmospheric Airborne Release } \\
\cline { 1 - 1 } Pressurized release & $5 \times 10^{-4} \mathrm{~g}$ \\
Leaking drum & $1 \times 10^{-4} \mathrm{fractional}$ release \\
Spill & $6 \times 10^{-5} \mathrm{~g}$ \\
Fire & $2.5 \times 10^{-5} \mathrm{~g}$ \\
Contanination spread & Significantly below upper-bound \\
Facility fire & Not credible
\end{tabular}

\subsubsection{Other Accidents Considered}

These releases are also listed in Table 5.14.

Leak. A leaking drum with liquid spilling from it could have a release of $0.01 \%$ of the source, based on experimental measurements of liquid spills (Sutter, Johnston and Mishima 1981). Therefore, this accident would have a lower release than some of the other postulated events.

Spill. A drum breach/spill of powder could have a fractional release of $0.12 \%$ in a static air situation. This would be a release of $240 \mathrm{~g}$ in the facility, challenging the high-efficiency particulate air filters for an atmospheric release of $6 \times 10^{-5} \mathrm{~g}$.

Fire. A fire could occur in powder-contaminated combustibles in a drum. The experimental release factor (Mishima and Schwendiman 1973) developed for this type event would be $100 \mathrm{~g} /$ drum inside the facility, $2.5 \times 10^{-5} \mathrm{~g}$ releasing to the atmosphere through 2 stages of high-efficiency particulate air filters. Since the facility and operation are still in the conceptual design phase, we cannot evaluate whether more than one drum would likely be involved in a fire. Since the drums are not opened, there would probably be no ignition source, so a fire is considered unlikely.

Contamination Spread. External contamination spread of smearable contamination from the exterior of waste packages could occur. This release would 
probably involve only very small levels of contamination overlooked when the packages were emplaced or from spread of package leaks. They would be at a lower level than spill or fire releases.

Facility Fire. Facility fires could be started by an external event such as a range fire or fuel truck hitting the facility. However, sparseness of the desert vegetation would lower the probability of such an event. The facility design is still conceptual, but it would probably be built of materials that would not sustain a fire.

\subsubsection{Processing}

Retrieved solid waste would be sent to the same facility and treated by slagging pyrolysis incineration much the same as TRU-contaminated soil (Section 5.4.2).

\subsubsection{Description of Operation and Facility}

For purposes of the Hanford Defense Waste Environmental Impact Statement slagging pyrolysis is used, as described earlier.

\subsubsection{Postulated Upper-Bound Accident}

This will be the same as in Section 5.4.2.2.

\subsubsection{Release Estimate for Upper-Bound Event}

This is the same as for TRU-contaminated soil in Section 5.4.2.3, and is listed in Table 5.15 .

\subsubsection{Other Accidents Considered}

These will be the same as for TRU-contaminated soil, with some additions considered because the waste is contained. Releases are included in Table 5.15 .

Fire. Various fires could be suggested, but they would have a lower release than the upper-bound event, which postulated breaching the facility. One such fire suggested that $2000 \mathrm{ft}^{3}$ of waste in the shipping area had a fractional release of $1 \times 10^{-9}$, one in the waste preparation area with $1 \times 10^{-6}$ 
TABLE 5.15. Postulated Airborne Releases from Accidents

During Processing of Pre-1970 TRU Solid Waste

\begin{tabular}{ll}
\multicolumn{1}{c}{ Event } & \multicolumn{2}{c}{ Atmospheric Airborne Release } \\
\cline { 1 - 1 } Explosion & $50 \mathrm{~g}$ \\
Criticality & Not postulated \\
Spill & $1.4 \times 10^{-5} \mathrm{~g}$ \\
Fire & $1 \times 10^{-6}$ fractional release $(\mathrm{a})$ \\
Oropped container & $2.5 \times 10^{-11}$ fractional release
\end{tabular}

(a) DOE (1979).

fractional release (DOE 1979). No fire was identified that was severe enough to burn through the reinforced concrete walls or destroy the second highefficiency particulate air filter.

Dropped Container. A dropped waste container was postulated to have a fractional release of $1 \times 10^{-4}$ (DOE 1979), entering the filtering system.

\subsection{RETRIEVABLY STORED AND NEWLY GENERATEO TRU}

Generated TRU solid waste in this category is remote handled or contact handled.

\subsubsection{Waste Retrieval}

Different retrieval methods are applied to remote-handled TRU and contacthandled TRU.

\subsubsection{Remote-Handled TRU}

Operation and Facility. Remote-handled TRU in caissons would be mechanically retrieved using an airtight, double-walled structure installed over the caissons. This building is shown in Figures 5.12 and 5.13 , with dimensions included. The caisson access shaft area was estimated to occupy about a quarter of the building. A conveyor system is used to transfer remote handled casks containing retrieved waste. 


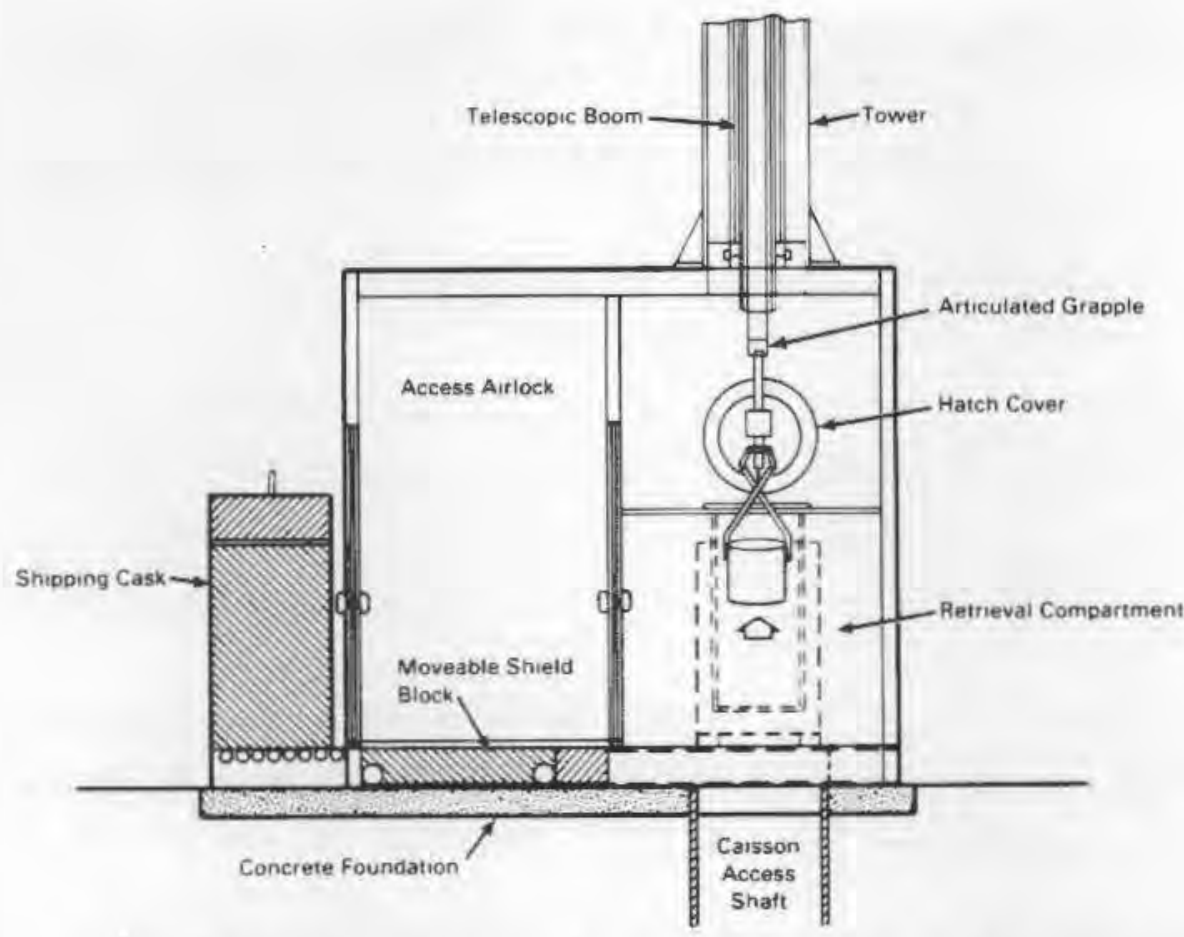

FIGURE 5.12. Caisson Recovery Building, Side View

The waste is retrieved using a grappler housing with a telescoping articulated boom. Operations are conducted remotely.

Postulated Upper-Bound Release Accident. The upper-bound accident is postulated as an explosion or pressurized release. The container is pressurized due to the buildup of radiolytic gases and subsequently ruptures.

Release Estimate for Upper-Bound Event. As noted in Section 5.5.2.3, 1\% of the source would become airborne as respirable particles. Since the waste can be in 3.82- $\mathrm{L}$ metal cans, has a density of $0.96 \mathrm{~g} / \mathrm{cm}^{3}$, and the source is $3.7 \times 10^{3} \mathrm{~g}, 37 \mathrm{~g}$ is airborne in the facility. Damage to the filters was considered but not postulated since a missile must be shot in perfect alignment with the filter to penetrate it. The postulated atmospheric release in $9.3 \times$ $10^{-6} \mathrm{~g}$. The release is listed in Table 5.16.

Other Accidents Considered. These releases are also listed in Table 5.16. 


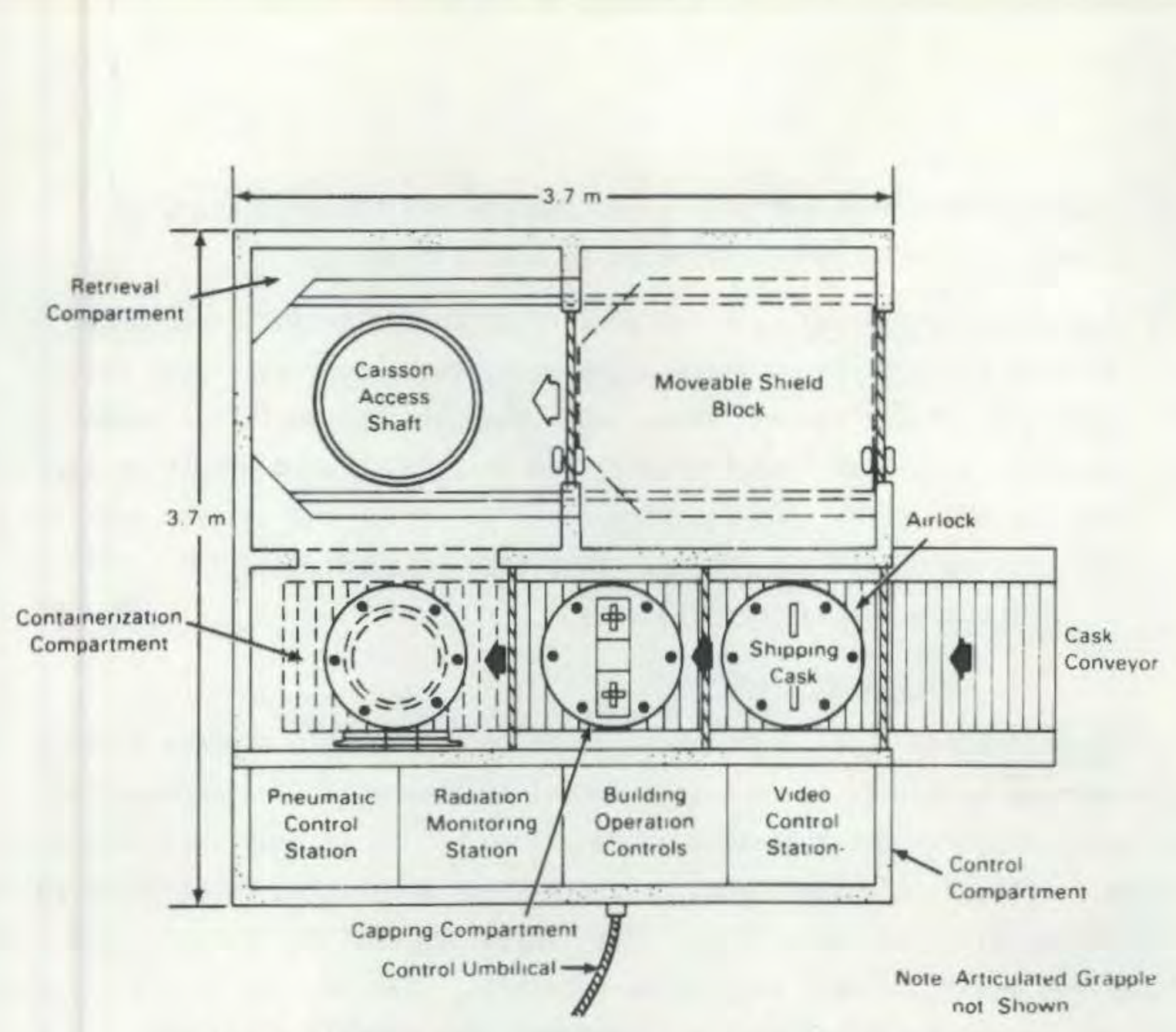

\section{FIGURE 5.13. Caisson Recovery Building, Top View}

TABLE 5.16. Postulated Airborne Releases from Accidents Retrieving Remote-Handled TRU in Caissons

\begin{tabular}{lll}
\multicolumn{1}{c}{ Event } & & Atmospheric Airborne Release \\
${$\cline { 1 - 1 }$} }$ & $9.3 \times 10^{-6} \mathrm{~g}$ \\
Spill & $1 \times 10^{-6} \mathrm{~g}$ \\
Contamination spread & Significantly below upper-bound
\end{tabular}

- Spill. A spill of material from a ruptured or breached package could release waste at a maximum level of about $0.12 \%$ as measured by Sutter, Johnston and Mishima (1981) in free-fall spills of powders in static air. The release would be within the facility or shaft with a minimal airflow, so a significantly higher release is not to be anticipated. Four grams would be airborne in the facility and 
challenge the high-efficiency particulate air filters, and the atmospheric release is estimated as $1 \times 10^{-6} \mathrm{~g}$.

- Contamination Spread. Spread of surface contamination could occur because the outside of waste packages could be contaminated. Packages are allowed to fall freely when they are stored in the caissons (Geiger, Brown and Isaacson 1977) and this fall could result in package ruptures. The contamination could be inside the caisson and on the outside of waste packages. This type of event should not lead to significant atmospheric releases.

\subsubsection{Contact-Handled TRU}

Operation and Facility. Waste placed in retrievable storage trenches and above-ground buildings is free of external contamination and packaged to maintain integrity for a minimum of 20 years. It is assumed that this waste can be retrieved in an open environment without generating an airborne release of radioactivity (Rockwell 1985). The overburden will be removed using conventional equipment and hand digging as required. Once the overburden has been removed, the packaged waste will be removed by a forklift or crane.

Postulated Upper-Bound Accident. An explosion or pressurized release of the contents of a waste package are suggested as a maximum release event. The pressurized release is probably initiated by the buildup of radiolytic gases.

Release Estimate for Upper-Bound Event. A 210-L drum packaging would appear to be susceptible to pressure buildup. The fractional release for remote-handled TRU, $1 \%$ respirable, is applicable here. At a waste density of $0.96 \mathrm{~g} / \mathrm{cm}^{3}$, the source is $2 \times 10^{5} \mathrm{~g}$ and $2 \times 10^{3} \mathrm{~g}$ becomes airborne imnediately. The release is listed in Table 5.17 .

Other Accidents Considered. Releases from other postulated accidents are listed in Table 5.17 .

- Spill. Waste containers can breach or rupture during various operations, and the contents spill. A portion of the contents could become airborne. An appropriate release fraction for this type of 
TABLE 5.17. Postulated Airborne Releases from Accidents During Grouting Decontaminated Salt Solutions

\begin{tabular}{ll}
\multicolumn{1}{c}{ Event } & \multicolumn{1}{c}{ Atmospheric Airborne Release } \\
\cline { 1 - 1 } Pressurized release & $2 \times 10^{3} \mathrm{~g}$ \\
Spill & $5 \times 10^{-3}$ fractional release \\
Puncture & No significant release \\
Fire & $5 \times 10^{-4}$ fractional release \\
Range fire & No significant release \\
Contamination spread & No significant release \\
Equipment failure & No significant release
\end{tabular}

event might be $0.12 \%$, as discussed in Section 5.6 .1 .1 .4 , if the event occurs in static air. However, if the operation is outside, it could be suspended by wind. If the wind is blowing at the average Hanford windspeed and $10 \%$ of the spilled material interfaces with the wind, the release fraction could be $5 \times 10^{-3}$ (Sutter 1980).

- Puncture. A waste package could be punctured by a forklift during retrieval. If a single hole is punched into the package, only a small amount of the waste is pulled out during withdrawal of the probe. This type of event should not have significant releases.

- Fire. A fire in a package of combustible waste could occur if nitric acid, for example, spilled onto cellulosic waste. The fractional release could be $5 \times 10^{-4}$ (Mishima and Schwendiman 1973). The largest box could contain $2 \times 10^{7} \mathrm{~g}$ of waste, $64 \mathrm{~m}^{3}$ at a waste density of $0.32 \mathrm{~g} / \mathrm{cm}^{3}$. However, the package would not be anticipated to hold that quantity of combustible waste. These large packages would probably hold large equipment that could not be decontaminated, pumps, tools, etc. Therefore it is considered unlikely that this waste would sustain a fire.

- Range fire. A range fire is not considered a threat to this operation. The gravel covering the waste would insure sparseness of vegetation so there would not be combustibles to fuel the fire. 
- Contanination Spread. Spread of contamination could occur if packages of waste with exterior contanination are excavated. Administrative controls as the waste is enplaced should ensure that spread does not take place. Although a package could leak, it wauld not involve significant levels of contamination.

- Equipnent Failure. An equipnent-related event such as an overturning of front-end loader could inpact the waste. Such an event should lack sufficient force to cause significant releases since the vehicles will be operating at very low speeds.

\section{6 .2 Sorting and Related operations}

\section{6 .2 .1 Remote-Handled TRU}

Remote-handled TRU would be processed with the TRUmcontaminated soll and pre-1970 solid waste. Therefore, the operation and facility, upper-bound accldent, release estimate for the upper-bound event, and other accldents consldered will be the sate as those for sorting the solid waste. These were discussed in Section 5.5.2 and listed in Table 5.14.

\section{6 .2 .2 Contact-Handled TRU}

Contact-handled TRU waste will be assayed and segragated in the contacthandled Waste Receiving and Processing facility. Thus, wastes are identlfied as to whether they are lowmevel or whether they are handled in this facllity. The operation and facility, upper-bound accident, release estinate for the upper-bound event, and other accidents considered will be the sane as those for other sorting operations. These were discussed in Section 5.5 .2 and listed in Table 5.14 .

\section{6 .3 Processing}

\section{6 .3 .1 Renote-Handled TRU}

Since the remote-handled TRU is processed by the slagging pyrolysis incinerator, the operation and facility, upper-bound accident, release estimate for upper-bound release event, and other accidents considered are the same as postulated in section 5.4.2. The releases from the slagging pyrolysis incinerator are listed in Table 5.12 . 


\subsubsection{Contact-Handled TRU}

Operation and Facility. Processing will involve size reduction, shredding and immobilizing the waste in concrete. The size reduction operation will select materials for the shredding that will prepare the waste to a form readily adaptable to immobilization. The waste is immobilized using a concrete mixture.

Postulated Upper-Bound Accident. Fire is suggested as the bounding accident for this operation. It is postulated to occur during shredding combustible waste. Waste dumped into the feed hopper could inadvertently contain solvent that spills on cellulosic material. Sparks from the grinder could then ignite the waste.

Release Estimate for Upper-Bound Event. One of the Targer packages used is an 80-gal (317 L) drun (Rockwell 1985). The material could be loosely packed cellulosics contaminated with radioactive powder. An overall density could be $0.32 \mathrm{~g} / \mathrm{cm}^{3}$, so the potential source is $1.5 \times 10^{5} \mathrm{~g}$. The appropriate release factor is $5 \times 10^{-4}$ of radioactive material (Mishima and Schwendiman 1973), and the calculated release in the facility is $50 \mathrm{~g} /$ drum of fine particles. It is conceivable that more than one drum load is in the hopper. Two drums would release $100 \mathrm{~g}$ in the facility to challenge the high-efficiency particulate air filters for the $2.5 \times 10^{-5} \mathrm{~g}$ release listed in Table 5.18 .

TABLE 5.18. Postulated Airborne Releases from Accidents During Sorting and Related Operations with Contact-Handled TRU

\begin{tabular}{ll}
\multicolumn{1}{c}{ Event } & \multicolumn{1}{c}{ Atmospheric Airborne Release } \\
Fire & $2.5 \times 10^{-5} \mathrm{~g}$ \\
Explosion & No significant release \\
Handling Accident & $2 \times 10^{-11}$ fractional release \\
Spill & $3 \times 10^{-10}$ fractional release \\
Leak & $2 \times 10^{-11}$ fractional release \\
Pressurized release & Not postulates
\end{tabular}


Other Accidents Considered. Releases fron the following less-than-upperbound accidents are listed in Table 5.18.

- Explosion. An explosion was considered at the Idaho National Engineering Laboratory (DOE 1979), but no potential source was identified for an explosion strong enough to breach the walls of the facility or to fall both high-efficiency particulate air filters and their associated dampers.

- Handling Accident. A handling accident has been postulated to occur in the compaction area at the Idaho National Engineering Laboratory (OOE 1979) with a release fraction of $10^{-4}$ in the ventilation flow. Particles generated by this event would be larger than those produced in a fire, making it of lesser concern.

- Spill. A waste container breach and spill could have a maximum 0.12\% fractional release (Sutter, Johnston and Mishima 1981) and produce fairiy large particles. While the fractional release appears larger than for the fire, the size of the particies make it less of an inhalation hazard. A secand mitigating consideration is that the spill could contain a larger portion of nonradioactive material.

- Leak. A liquid leak should result in a $0.01 \%$ fractional release. It would be assumed that very little liquid would be contained in the waste at this process step. Leaks would be identified in the earlier sorting and related operation.

- Pressurized Release. Pressurized releases from drums have been suggested in earlier process modules. The materials are not packaged during the sorting and shredding operations. Reactions by the inaterials would be most likely to occur, if any reactions are possible, during this time. Only after these operations is the material restrained in concrete. Pressurized release is not considered as a likely event for this process step. 


\subsection{POSTULATED RELEASES FROM POTENTIAL ACC IDENTS ASSOCIATED WITH IN-PLACE STABILIZATION \\ AND DISPOSAL OF SIX WASTE FORMS}

For the in-place stabilization and disposal alternative, there would be little processing or treatment of wastes except for those stored in doubleshell tanks. Releases for each of the waste forins are developed in the following sections, and are listed in Table 6.1.

\subsection{EXISTING TANK WASTE}

\subsubsection{Dry Single-Shell Tanks}

Waste left in place in single-shell tanks would be dried as required to achieve adequate stability.

\subsubsection{Description of Operation and Facility}

One proposed drying method would use microwave energy to heat and thereby dry the waste. This technique could radiate microwave energy into the interior of an underground tank and heat the waste in a manner sinilar to microwave cooking. Portable generators would transmit energy into the tank interior via coaxial cables. Air would be discharged through two high-efficiency particulate air filters.

\subsubsection{Postulated Upper-Bound Release Event}

The postulated upper-bound release event would be the explosion described for single-shell tanks in Section 5.l.1.2.

\subsubsection{Release Estimate for Upper-8ound Event}

Section 5.1.1.3 develops an estimate of $1.3 \times 10^{4} \mathrm{~g}$ of respirable material airborne and is listed in Table 6.2.

6.1.1.4 other Accidents Considered

Some other accidents considered are listed in Table 6.2. 
TABLE 6.1. In-Place Stabilization and Disposal Alternative Potential Accidental Releases for Operations Involving $\$ 1$ xaste Forns

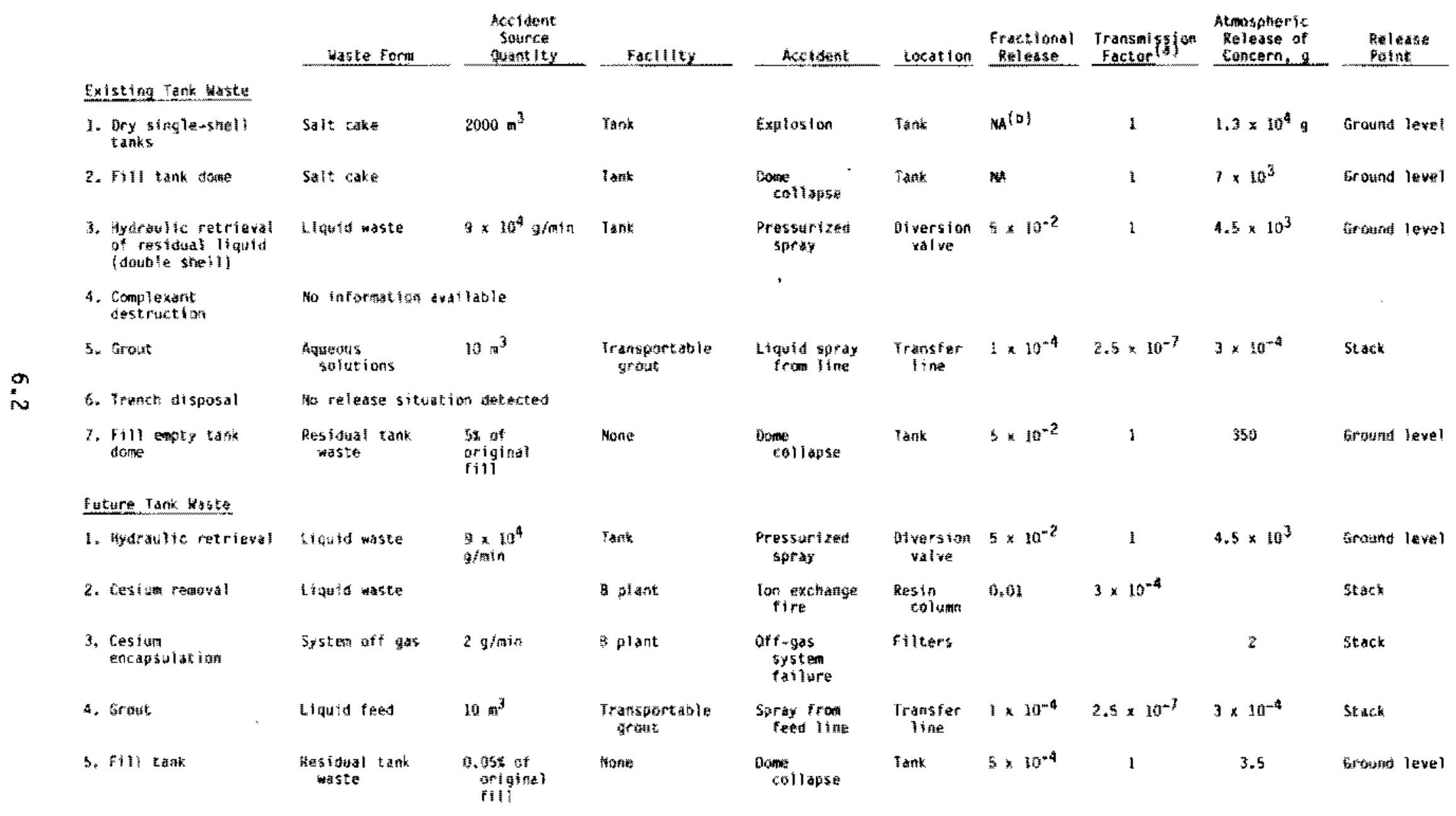


TABLE 6.1. (contd)

\begin{tabular}{|c|c|c|c|c|c|c|c|c|c|}
\hline & Waste form & $\begin{array}{l}\text { Accident } \\
\text { Source } \\
\text { Quantity } \\
\end{array}$ & facility & Accident. & Locacion & $\begin{array}{l}\text { Fractional } \\
\text { Release } \\
\end{array}$ & $\begin{array}{l}\text { Transmigston } \\
\text { Eactar a }\end{array}$ & $\begin{array}{l}\text { Remospheric } \\
\text { Release of } \\
\text { Concern, } g\end{array}$ & $\begin{array}{l}\text { Aalease } \\
\text { Point }\end{array}$ \\
\hline \multicolumn{10}{|c|}{ Scrontiun and Cestur copsates } \\
\hline 1. Renove fron thesf & $\begin{array}{l}\text { Encrosulated } \\
\text { maste }\end{array}$ & $2 \times 10^{3}$ & WESF $(t)$ & $\begin{array}{l}\text { Capside } \\
\text { Fuptertar }\end{array}$ & $\begin{array}{c}5 \operatorname{trorage} \\
\text { arem }\end{array}$ & 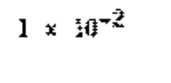 & $2.3 \times 10^{-7}$ & $5.5 \times 10^{-6}$ & SEdx \\
\hline 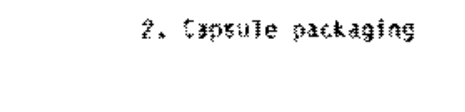 & 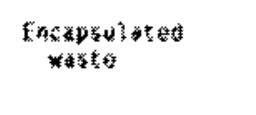 & $2.2 \times 10^{3}$ & 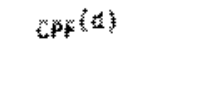 & 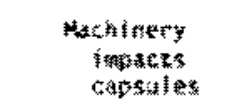 & $\begin{array}{l}\text { "totede } \\
\text { Secteten }\end{array}$ & $1.2 \times 10^{-3}$ & $2 . x \times 1 y^{-7}$ & $5.5 \times 10^{-3}$ & stats \\
\hline 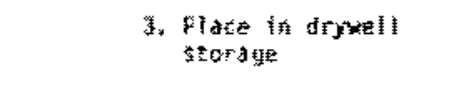 & 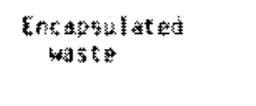 & $2.2 \times 10^{3} 3$ & aws? & 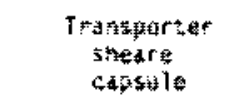 & Dusto & $1 \times 1 y^{-6}$ & 1 & $2.2 \times 10^{-3}$ & 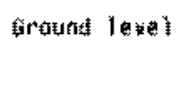 \\
\hline \multicolumn{10}{|l|}{ Tede-Cont arrinated Soil } \\
\hline 1. Inject grout & $\begin{array}{l}\text { routumbent ani fated } \\
\text { soil }\end{array}$ & $8.1 \times 10^{7}$ & mone & $\begin{array}{l}\text { Void spate } \\
\text { collifaptas }\end{array}$ & $\mathrm{CK} 1 \mathrm{~B}$ & $3 \times 10^{-6}$ & 1 & 2.6 & groutat level \\
\hline \multicolumn{10}{|l|}{ 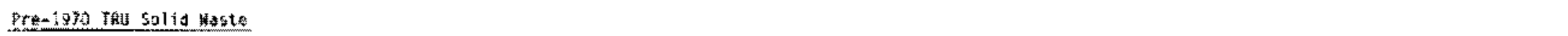 } \\
\hline 1. Garout taissons & 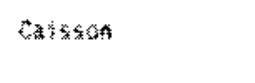 & $3.7 \times 10^{3} 5$ & tane & $\begin{array}{l}\text { Equipment } \\
\text { fatiofte }\end{array}$ & Colsson & $7 \times \mathrm{cos}^{-1}$ & 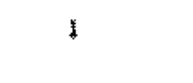 & $3 \times 50^{-4}$ & Srowted leve! \\
\hline z. Subcitcetce contron & 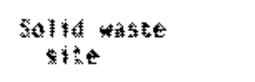 & $8.1 \times 10^{7}$ & tortat & 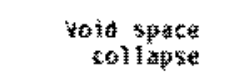 & 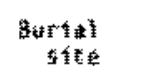 & $3 \times 10^{-6}$ & 1 & 2.6 & Gatoind lavel \\
\hline \multicolumn{10}{|c|}{ 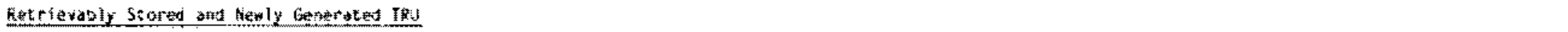 } \\
\hline 1. Sutsídentè control & $\begin{array}{l}\text { Rentievable } \\
\text { stored lku }\end{array}$ & $8.1 \times 10^{7} 9$ & None & $\begin{array}{l}\text { vold space } \\
\text { collipse }\end{array}$ & $\begin{array}{l}\text { Burial } \\
\text { site }\end{array}$ & $3 \times 10^{-6}$ & 1 & 2.6 & Ground tevet \\
\hline 2. Aury packaged-waste & TRej waste & $2 \times 10^{5} 9$ & None & $\begin{array}{c}\text { Package } \\
\text { breach }\end{array}$ & $\begin{array}{l}\text { gurial } \\
\text { site }\end{array}$ & $5 \times 10^{-3}$ & 1 & $1 \times 10^{3} q$ & Sround level \\
\hline 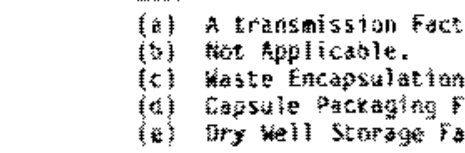 & 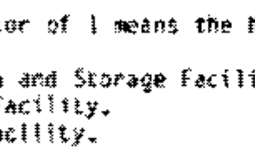 & 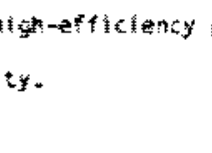 & 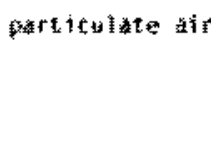 & filters ara or & to fat en & flosed. & & & \\
\hline
\end{tabular}


TABLE 6.2. Postulated Airborne Releases from Accidents During In-lank Drying of Single-Shell Waste

\begin{tabular}{lc}
\multicolumn{1}{c}{ Event } & $\begin{array}{c}\text { Atmospheric } \\
\text { Airborne Release }\end{array}$ \\
Explosion & $1.3 \times 10^{4} \mathrm{~g}$ \\
$\begin{array}{l}\text { Loss of filtration } \\
\text { 1st stage }\end{array}$ & $5 \times 10^{-6} \mathrm{~g} / \mathrm{m}^{3}$ \\
Both stages & $1 \times 10^{-2} \mathrm{~g} / \mathrm{m}^{3}$ \\
Loss of services & No significant \\
or power & release \\
Spattering & $2.5 \times 10^{-9} \mathrm{~g} / \mathrm{m}^{3}$
\end{tabular}

Spattering could occur if internal heating of the waste were uneven; presm sure could build up, with subsequent ejecting of waste through the crust into the tank void space. It is estimated that $100 \mathrm{mg} / \mathrm{m}^{3}(0 \mathrm{RN}$ 1970) is in the airflow, with $10 \%$ less than 10 un aerodynanic equivalent diameter in dismeter. This event should not breach the filters, so the release would be at a lower level than the maximum.

\section{1 .2 Tank Dome Filling}

Tank dome voids above the waste in both the single- and double-shell tanks wĩl be filled.

\subsubsection{Description of Operation and Factlity}

The same techniques used to fill empty tanks wlll be used to fill the done voids. These were discussed in section 5.1.6.1.

\section{1 .2 .2 Postulated Upper-Bound Accident}

A dome collapse would be the postulated upper-bound accident as discussed in Section 5.1.6.2.

\subsubsection{Release Estimate for Upper-8ound Event}

The source quantity available to be relatsed will be larger from these full tanks than the emptied tanks. Therefore a larger release is anticipated from this done collapse. Rockwell (1985) estimated a $7 \mathrm{~kg}$ release; Hayward and 
Jensen (1980) suggested a $5 \times 10^{-8}$ fractional release. The $7-\mathrm{kg}$ value is the selected upper-bound release and is listed in table 6.3.

6.1.2.4 Other Accidents Considered

These accidents will be the same as those discussed in Section 5,1.6.4 and are listed in Table 6.3. They include loss of filtration, loss of service or power, and equipment failure.

\subsubsection{Hydraulic Retrieval of Residual Liquid}

Residual liquor and other liquid waste from double-shell tanks would be retrieved hydraulically.

\subsubsection{Description of Operation and Facility}

The sluicing operation is described in Section 5.1.2.1.

\subsubsection{Postulated Upper-Bound Accident}

The sluicing operation will be the same as that described in Section 5.0; therefore, the accident hypothesized in Section 5.1.2.2, a pressurized release of sprayed liquid waste, is the upper-bound accident.

TABLE 6.3. Postulated Airborne Releases from Accidents During Dome Filling

\begin{tabular}{|c|c|}
\hline Event & $\begin{array}{c}\text { Atmospheric } \\
\text { Airborne Release }\end{array}$ \\
\hline Dome collapse & $7 \mathrm{~kg}$ \\
\hline $\begin{array}{l}\text { Loss of filtration } \\
\text { lst stage } \\
\text { Both stages }\end{array}$ & $\begin{array}{lll}5 \times 10^{-6} & \mathrm{~g} / \mathrm{m}^{3} \\
1 \times 10^{-2} & \mathrm{~g} / \mathrm{m}^{3}\end{array}$ \\
\hline $\begin{array}{l}\text { Loss of services } \\
\text { or power }\end{array}$ & $\begin{array}{l}\text { No significant } \\
\text { release }\end{array}$ \\
\hline Equipment failure & $\begin{array}{l}\text { No significant } \\
\text { release }\end{array}$ \\
\hline
\end{tabular}




\subsubsection{Release Estimate for Upper-Bound Event}

As described in Section $5.1 .2 .3,9 \times 10^{4} \mathrm{~g} / \mathrm{min}$ is pumped and has $5 \times$ $10^{-2}$ fractional release in the accident. Thus the release is $4.5 \times 10^{3} \mathrm{~g} / \mathrm{min}$, as listed in Table 6.4 .

\subsubsection{Other Accidents Considered}

These are discussed in Section 5.1.2.4, and include a slurry sp111, loss of services or power, and loss of filtration. Releases are listed in Table 6.4 .

\subsubsection{Complexant Destruction}

Wastes with high concentrations of organic complexants would be treated to reduce the concentrations to an acceptable level. This process has not been developed, so no releases can be estimated.

\section{1 .5 Grout}

Treated residual aqueous solutions would be treated to convert then to a cenentitious grout. The waste would be processed through the transportable grout facility. The operation and facility, postulated upper-bound accidents, the release estimate for uppermbound event, and other accidents considered will be the same as those in Section 5.1,5. Releases are listed in Table 6.5.

TABLE 6.4. Postulated Airborne Releases froh Accident During Hydraulic Retrieval of Residual Liquid

\begin{tabular}{|c|c|}
\hline Event & $\begin{array}{c}\text { Atmospheric } \\
\text { Airborne Release } \\
\end{array}$ \\
\hline $\begin{array}{l}\text { Pressurized liquid } \\
\text { spray }\end{array}$ & $4.5 \times 10^{3} \mathrm{~g} / \mathrm{min}$ \\
\hline Slurry splll & $\begin{array}{l}1 \times 10^{-4} \text { fraction, } \\
\text { plus resuspension }\end{array}$ \\
\hline $\begin{array}{l}\text { Loss of services or } \\
\text { power }\end{array}$ & $\begin{array}{l}\text { No significant } \\
\text { release }\end{array}$ \\
\hline $\begin{array}{l}\text { Loss of filtration } \\
\text { lst stage } \\
\text { Both stages }\end{array}$ & $\begin{array}{l}5 \times 10^{-6} \mathrm{~g} / \mathrm{m}^{3} \\
1 \times 10^{-3} \mathrm{~g} / \mathrm{m}^{3}\end{array}$ \\
\hline
\end{tabular}


TABLE 6.5. Postulated Airborne Releases from Accidents During Grouting Operation

\begin{tabular}{|c|c|}
\hline Event & $\begin{array}{c}\text { Atmospheric } \\
\text { Airborne Release }\end{array}$ \\
\hline Spray (solution) & $3 \times 10^{-4} \mathrm{~g}$ \\
\hline Solution tank leak & $2 \times 10^{-8(a)}$ \\
\hline Mixer tank leak & $\begin{array}{l}\text { Significantly below } \\
\text { upper-bound }\end{array}$ \\
\hline Grout spill & $\begin{array}{l}\text { Significantly below } \\
\text { upper-bound }\end{array}$ \\
\hline
\end{tabular}

(a) Hayward and Jensen (1980).

\subsubsection{Trench Disposal of Grout}

Grouted waste will be disposed of in trenches.

\subsubsection{Description of Operation and Facility}

The grout burial trenches are of earthen construction with a menbrane liner. They are $15 \mathrm{~m}$ wide, with sloping sides, and are $8 \mathrm{~m}$ deep. This trench, $100 \mathrm{~m}$ long and filled to a depth of $3 \mathrm{~m}$, can hold $5400 \mathrm{~m}^{3}$ of grouted waste. An air support bubble dome is used during filling for weather protection and to prevent airborne dispersal of the waste. Once the trench is filled and the grout is cured, the dome will be removed and the trench backfilled with $5 \mathrm{~m}$ of soil.

\subsubsection{Postulated Upper-Bound Accident}

No significant potential for airborne release was identified.

\subsubsection{Accidents Considered}

Since no releases were developed, a table was not developed.

Grout Leak. It is postulated that grouted liquid is inadvertently released. A variety of mechanisms could be responsible, such as a leaking connection or a break while making the grout. The quantity released would depend upon the circumstances. But the nature of the material makes a serious airborne release unlikely. The grout is viscous and difficult to subdivide 
into fine particles (much of the material used to make the grout is coarse). The level of radioactivity in the grout is low. Therefore, it is estimated that this type of event would result in an insigniflcant (but unquantified) aírborne release.

Grout Spray. In order for the grout to be sprayed, a considerable pressure would be required, much in excess of that needed simply to nove the grout. No situation which could result in such a stuation was postulated, and this event was not considered significant.

Slope or Trench Fablure During Loading. The grout is laid in the bottom of a trench through multiple nozzles. If the sides of the trench were to col* lapse due to insufficient strength of the soil, the soll sliding into the trench could cause the grout to be splashed. As nentioned in the grout spill scenario, the airborne release would be insignificant and the most probable result of this event would be the inadvertent burial of the grout.

Fallure of the Atr Bubble Done. Loss of the air bubble dome would expose the uncured grout to the atmosphere and, in inclement weather might interfere with the proper curing and aging of the grout. These are operational cancerns but do not appear to pose a serious airborne hazard.

Loss of Services or Power. Loss of services or power could result in cessation of operations or exposure of the grovt. Neither consequence appears to pose a serious airborne release situation.

\subsection{FUTUKE TANK WASTE,}

\subsubsection{Hydraulic Retrieval}

Wastes in double-shell tanks (neutralized current acid wastes) would be retriaved by hydraulic sluticing.

\section{2 .1 .1 Description of Operation and Facillty}

The slujcing operation is described in Section 5.1.2.1.

\section{2 .1 .2 Postulated Upper-Bound Accident}

The sluicing operations are the sane, therefore the suggested accident in Section 5.1 .2 .2 applies, i.e., a release of pressurized liquid as a spray. 


\subsubsection{Release Estimate for Upper-Bound Event}

As described in Section $5.1 .2 .3,9 \times 10^{4} \mathrm{~g} /$ min is pumped and has $5 \times$ $10^{-2}$ fractional release in the accident. Thus the release if $4.5 \times 10^{3} \mathrm{~g} / \mathrm{min}$ as listed in Table 6.4.

6.2 .1 .4 Other Accidents Considered

These are described in section 5.1.2.4 and listed in Table 6.4.

\section{$6.2,2$ Casiun Renoval}

\section{2 .2 .1 Description of operation and Facllity}

Due to the small rolume of waste involved, the waste is processed through B Plant and the waste encapsulation and storage facility. The cesiun is renoved in an exchange column and converted to solid cesium chloride for encapsulation.

\section{2 .2 .2 Postulated Lpper-Bound Release Accident}

The upper-bound is the ion exchange fire postulated in Section 5.1 .3 .3 .

\section{2 .2 .3 Release Estimate for Upper-Bound Release Event}

These are discussed in Section $5.1,3.3$ and listed in Table 6.6.

\section{2 .2 .4 Qther Accidents Considered}

A tank leak and equipment fatlure were considered in section 5.1 .3 .3 . Some others follow, and are listed in Table 6.6 .

Filter Fire. If the highmefficiency particulate air filters are subjected to high temperatures for extended periods of time, the glass fiber melts, resulting in loss of filtration. Whether the material accumulated can be released or is trapped by the shrinking glass fibers is yet to be defined. Loss of filtation without loss of flow would result in the release of the particles airborne in the cell. If no credi is taken for the removal of particles by other components of the off-gas system, all the airborne particles are assumed to be released to the atmosphere. Ion exchange removal is a wet process and is not particularly dusty. It is assumed that the mass airborne concentration is $10 \mathrm{mg} / \mathrm{m}^{3}$ and the ventilation flow is $20 \mathrm{~m}^{3} / \mathrm{min}$ resulting in the release of $0.2 \mathrm{~g} / \mathrm{min}$. 
IABLE 6.6. Postulated Fractional Airborne Releases

from Accidents During Cesium Recovery

$\begin{array}{ll}\text { Event } & \begin{array}{c}\text { Atmospheric } \\ \text { Fractional Release }\end{array} \\ \begin{array}{l}\text { Cesium ion } \\ \text { exchange fire }\end{array} & \begin{array}{l}3 \times 10^{-6(a)} \\ \text { fractional release }\end{array} \\ \begin{array}{l}\text { Filter fire/filter } \\ \text { failure }\end{array} & \begin{array}{l}2 \times 10^{-9}(\mathrm{~b}) 0.2 \mathrm{~g} / \mathrm{min} \\ \text { fractional release }\end{array} \\ \begin{array}{l}\text { Loss of services or } \\ \text { power }\end{array} & \text { No significant release } \\ \begin{array}{l}\text { Rupture of ion } \\ \text { exchange column }\end{array} & \text { Insufficient data }\end{array}$

(a) DOE (1982).

(b) Rockwell (1980).

Loss of Services or Power. Loss of services or power could result in a variety of consequences depending upon the services and the equipment powered. Most of the consequences envisioned have been covered by the other events described, and a greater airborne release than estimated for these events is not anticipated.

Rupture of the Ion Exchange Column. Loss of containment of the resin and solution would result in the airborne release of some of the liquid by freefall spill. If the resin is not recovered, it could dry and be available for combustion. Such an event is not likely since the operation would be actively monitored while high-level material is present. Thus it is not anticipated that this event could result in an ajrborne release greater than those already covered.

\subsubsection{Cesium Encapsulation}

Information on cesium encapsulation is taken from the Waste Encapsulation and Storage Facility safety analysis report (Braden et al. 1971). Although no description of the process was included in the Hanford Defense Waste Environmental Impact Statement, the process currentiy used at the facility is assumed to be similar to that described in the safety analysis report. 


\subsubsection{Deseription of Operation and Factlity}

The waste Encapsulation and Storage Facility where the operation takes place is described in detail by Braden et al. (1971).

Cesium encapsulation begins when concentrated cesium carbonate is conm verted to cestum chloride by batch contact with 12 molar hydrochloric acid. ceslum chloride was selected as the optinal compound for encapsulation for various reasons, anong which are high cestum density, compatibility with encapsulating materials, and negligible radiolytic decomposition for the anhydrous material. The ceslun chloride solution is heated to boiling in the evaporatormelter, and after the drying step is slowly heated to its melting temperature (approximately $645^{\circ} \mathrm{C}$ ). During the high-temperature drying and melting operation, the atmosphere inside the melter is purged with argon to reduce the corrosion potentlal. Some ceslum chloride is volatillzed during this operation, and the melter vent line is equipped with a de-entralner for collecting this material. The collected material is recycled back to the melter and included in the next batch.

The molten cesium chloride is cast in cylindrical, type 316 L stainless steel, primary containers as shown in Figure 4.1. CCapsule parameters are listed in Table 4.1.) After the castings are cooled, caps are placed on the containers and welded to the containers using an inert atmosphere. Each capsule is leat tested, decontaminated by ultrasontc cleaning, weighed, weldcested, and calorimetered. Interin storage is in water-filled basin (described in Section 5.3.1). Equipment used in the process, including the off-gas system (caustic scrubbers, de-entratner, heater, filters), are described by Braden et al. (1971).

\section{2 .3 .2 Postulated upper-Bound Accident}

As previously discussed, loss of all components of the off-gas and ventilation systens (two separate systens) is not credible unless some events simultaneously occur within the systems with sufficient energy generated to breach the systems. A loss of the system can occur with loss of airflow or continued airflow. A loss with loss of flow results in venting the contained airborne nateriais slowly by difusion. In the event of loss of function with continued 
flow and melter operation, the release from this operation could be very high due to the volatilization of cesium chloride. Loss of filtration (loss of both stages of the high-efficiency particulate air filters - an unlikely event) without loss of ventilation flow would release the materials already airborne in the cell to the atmosphere, and is the postulated upper-bound accident.

\subsubsection{Release Est imate for Upper-Bound Event}

Cesium encapsulation may be a dusty operation, and a mass airborne concentration of $100 \mathrm{mg} / \mathrm{m}^{3}$ is applied. Assuming the same ventilation rate as in previous discussions of this situation $\left(20 \mathrm{~m}^{3} / \mathrm{min}\right)$, the mass airborne release to the atmosphere would be $2.0 \mathrm{~g} / \mathrm{min}$, as listed in Table 6.7 .

\subsubsection{0ther Accidents Considered}

Other accidents considered are also listed in Table 6.7 .

\section{TABLE 6.7. Postulated Airborne Releases from Accidents During Cesium Encapsulation}

\begin{tabular}{|c|c|}
\hline Event & $\begin{array}{c}\text { Atmospheric } \\
\text { Airborne Release }\end{array}$ \\
\hline $\begin{array}{l}\text { Loss of off-gas } \\
\text { exhaust system }\end{array}$ & $2 \mathrm{~g} / \mathrm{min}$ \\
\hline Canister drop & $\begin{array}{l}8 \times 10^{-6(a)} \\
\text { fractional release }\end{array}$ \\
\hline $\begin{array}{l}\text { Hydrogen accumulation } \\
\text { and explosion }\end{array}$ & $\begin{array}{l}3 \times 10^{-4(b)} \\
\text { fractional release }\end{array}$ \\
\hline $\begin{array}{l}\text { Spill of molten cesium } \\
\text { chloride }\end{array}$ & $\begin{array}{l}\text { Significantly below } \\
\text { upper-bound }\end{array}$ \\
\hline Fire & $\begin{array}{l}\text { Significantly below } \\
\text { upper-bound }\end{array}$ \\
\hline $\begin{array}{l}\text { Loss of services or } \\
\text { power }\end{array}$ & No significant release \\
\hline $\begin{array}{l}\text { (a) Richardson }(1980) \\
\text { (b) DOE (1982). }\end{array}$ & \\
\hline
\end{tabular}


Spill of Molten Cesium Chloride. It is postulated that due to a process malfunction, molten cesium chloride is released to the cell. As in the discussion of the spill of molten glass, it is believed that the molten material would cool rapidly and solidify. Some airborne release to the cell atmosphere would occur during the cooling but, if the exhaust system is operational, the release to the outside atmosphere would be minor.

Volatilization of Cesium Chloride. Some volatilization normally occurs during operational heating of the cesium chloride to melting. The volatilized material is controlled by the off-gas system. Loss of the off-gas system or the release of molten material to the cell has been discussed in previous sections.

Canister Drop. No scenario was postulated for this event by Richardson (1980); however, he postulated a release. It is assumed that some process malfunction causes the drop of an unencapsulated container full of cesium chloride. The airborne release to the atmosphere listed in the reference is shown in Table 6.7 .

Fire. Fire in the in-cell filters was considered by Braden et al. (1971) to be the most serious radiologic hazard to the Waste Encapsulation and Storage Facility. It was postulated that all the accumulated material could be released to the facility filtration system, which is postulated to remain functional. In this operation, the material is volatile at higher temperatures and release is more probable. Since the facility high-efficiency particulate air filters are assumed to remain operational, the airborne release to the environs is estimated to be minor.

Hydrogen Accumulation and Explosion. A detonation of accumulated hydrogen from the radiolysis of water was postulated (Braden et al. 1971) in one of the tanks holding a concentrated radionuclide solution. The facility filters remain operational and the airborne release to the outside atmosphere is minor.

Loss of Services or Power. Various losses of services or power are discussed by Braden et al. (1971); vessel coil failure, loss of cooling water, loss of process or instrument air, loss of electrical power, etc. None of the release consequences from these events is as serious as those covered above. 


\subsubsection{Grouting Neutralized Current Acid Waste Supernatant Liquids}

After removal of cesium, the neutralized current acid waste supernatant liquid would be concentrated by evaporation and converted to grout.

\subsubsection{Description of Operation and Faciltty}

The neutralized current acid waste residues would be combined with other wastes and processed through the transportable grout facility as described in Section 5.1 .5 .1 .

\section{2 .4 .2 Postulated Upper-Bound Accident}

As in section $5,1,5,2$, the upper-bound release is a spray of the feed solution.

\subsubsection{Release Estinate for Upper-Bound Event}

The atnospheric release developed in section 5.1 .5 .3 and 1 isted in Table 6.8, is $3 \times 10^{-4} \mathrm{~g}$ of salt solution.

TABLE 6.8. Postulated Airborne Releases from Accidents During Neutralized Current Acid Waste Grouting Operations

Atmospheric

Event

Spray of neutralized current acid waste solution

Salt solution tank leak

Mixer tank leak

Grout $s p i l l$

\section{Ajrborne Release}

$3.0 \times 10^{-4}$

$2 \times 10^{-6}(a)$

fractional release

Significanty below upper-bound

Significantily below upper-bound

(a) Hayward and Jensen (1980). 


\section{2 .4 .4 Other Actidents Considered}

Additional accidents beyond those listed in section 5.1 .5 .4 are not considered.

\section{2 .5 Fill Tank}

Filling the empty tanks will be the same operation used for future waste in Section 5.2.5. The operation and facility, postulated uppermound accident, release for upper-bound event, and other accidents considered are described there. Releases are listed in Table $6.9 *$

\subsection{STRONTLUN AND CESLUM CAPSULES}

Storage of the strontium and cesiun capsules in the Waste Encapsulation and storage Facility continues to allow decay time. After 20 to 40 years the heat generated would be low enough to perit passive cooling of the encapsulated waste.

\subsubsection{Capsule Retrieval}

This is the same operation described in section 5.3.1. It includes the description of the operation and facility, postulated upper-bound accident, release estimate for upper-bound event, and other accidents considered. Releases are listed in Table 6,10 .

TABLE 6.9. Postulated Airborne Releases froin Accidents During Filling of Enpty Tanks

\begin{tabular}{|c|c|}
\hline Event & Atnospheris Release \\
\hline Wome collapse & 3.59 \\
\hline $\begin{array}{l}\text { Loss of flitration } \\
\text { lst stage } \\
\text { Both stages }\end{array}$ & $\begin{array}{l}5 \times 10^{-6} \mathrm{~g} / \mathrm{m}^{3} \\
1 \times 10^{-2} \mathrm{~g} / \mathrm{m}^{3}\end{array}$ \\
\hline $\begin{array}{l}\text { Loss of services or } \\
\text { power }\end{array}$ & No significant release \\
\hline Equipment failure & No significant release \\
\hline
\end{tabular}


TABLE 6.10. Postulated Airborne Releases from Accidents During Retrieving Capsules

\begin{tabular}{|c|c|}
\hline Event & $\begin{array}{c}\text { Atmospheric } \\
\text { Airborne Release }\end{array}$ \\
\hline Capsules rupture & $5.5 \times 10^{-6} \mathrm{~g}$ \\
\hline $\begin{array}{l}\text { Capsule drop in } \\
\text { basin }\end{array}$ & \\
\hline Cover drop & $\begin{array}{l}3 \times 10^{-10(a)} \\
\text { fractional release }\end{array}$ \\
\hline $\begin{array}{l}\text { Hydrogen accumulation/ } \\
\text { explosion }\end{array}$ & $\begin{array}{l}1 \times 10^{-15(b)} \\
\text { fractional release }\end{array}$ \\
\hline Loss of filtration & $\begin{array}{l}\text { Significantly below } \\
\text { upper-bound }\end{array}$ \\
\hline Fire & No significant release \\
\hline $\begin{array}{l}\text { Loss of Services or } \\
\text { power }\end{array}$ & No significant release \\
\hline Capsule faflure in bas & No significant release \\
\hline
\end{tabular}
(a) DOE (1982).
(b) Richardson (1980).

\section{3 .2 Capsule Packaging}

This is the capsule packaging process described in Section 5.3 .2 that includes a description of the operation and factlity, postulated uppermound accident release estimate for upper-bound event, and other accidents considered. Releases are listed in Table 6.11.

\section{3 .3 Place Capsules in Drywe11 Storage}

Drywell disposal is the proposed canister storage for in-place stabilization.

\section{3 .3 .1 Description of operation and Facllity}

Canisters are transported to the drywell disposal area by a shielded-cask transporter (Figure 6.1). The canisters will be lowered into drywells (one per drywell is assumed) by the transporter vehtcle that also discharges sand into 


\section{TABLE 6.11. Postulated Airborne Releases from Accidents}

During Capsule Packaging

\begin{tabular}{|c|c|}
\hline Event & $\begin{array}{l}\text { Atmospheric } \\
\text { Airborne Release }\end{array}$ \\
\hline Package element failure & $6.6 \times 10^{-7} \mathrm{~g}$ \\
\hline $\begin{array}{l}\text { Capsule damage during } \\
\text { processing }\end{array}$ & $3 \times 10^{-10(a)}$ \\
\hline Handling/canister drop & $7 \times 10^{-16(b)}$ \\
\hline Fire & $8 \times 10^{-6(c)}$ \\
\hline $\begin{array}{l}\text { Loss of off-gas exhaust } \\
\text { system }\end{array}$ & $\begin{array}{l}\text { Significantly below } \\
\text { upper-bound }\end{array}$ \\
\hline
\end{tabular}

(a) DOE (1982).

(b) Hayward and Jensen (1980).

(c) Richardson (1980).

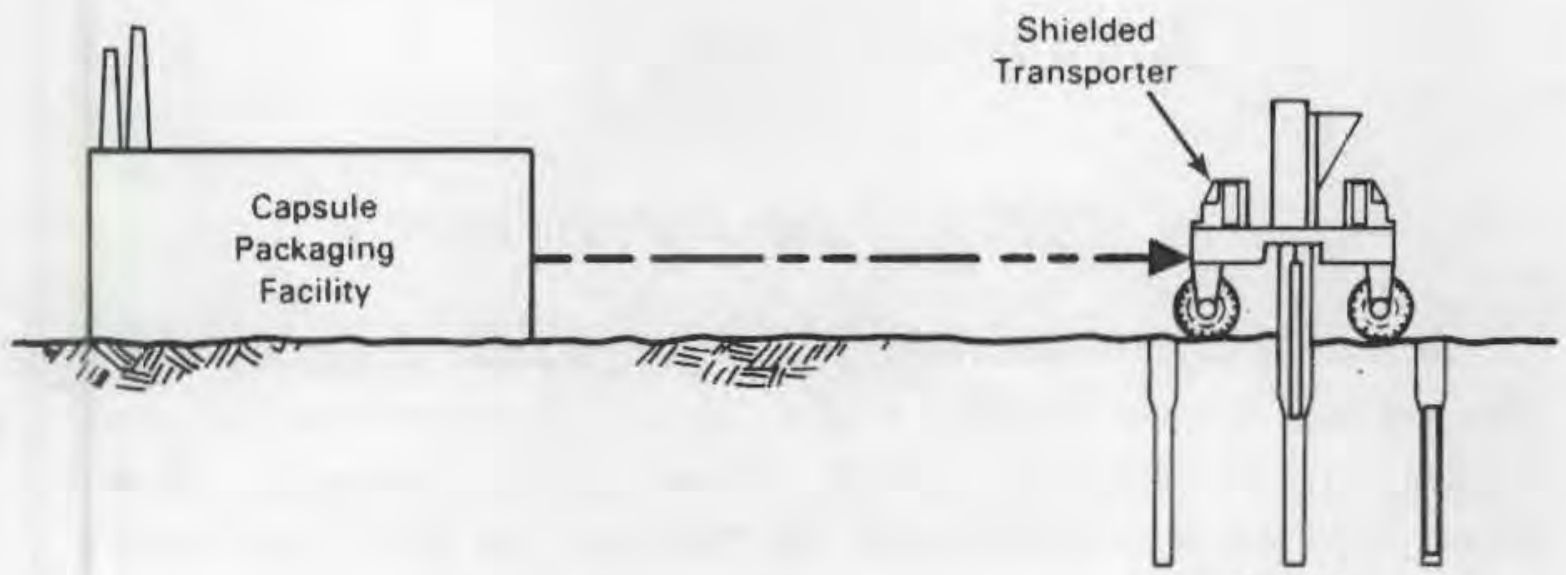

Drywell

Storage Facility

FIGURE 6.1. Transfer of Strontium and Cesium Capsules from the Capsule Packaging Facility to the Drywell Storage Facility

the space above the canister to fill the upper portion of the drywell. A typical drywell assembly is shown in Figure 6.2. Planned detailed engineering studies may show the feasibility of a dry, overpack disposal either in the open air or in a facility. 


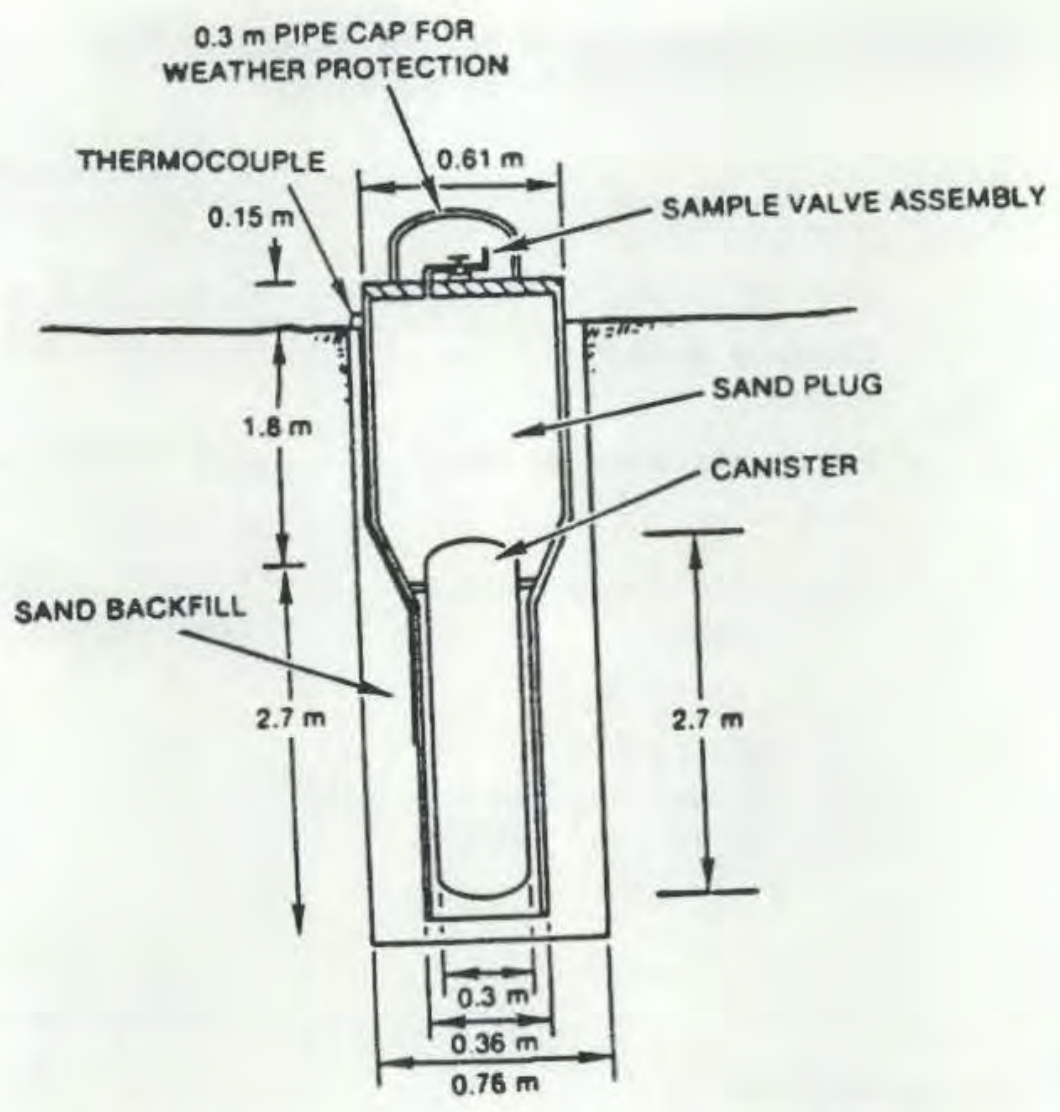

FIGURE 6.2. Typical Drywell Assembly

Given the drywell configuration assumed, a total of 274 drywells will be required. Each drywell consists of a cylindrical carbon steel encasement vessel that extends approximately $0.15 \mathrm{~m}$ above and $4.6 \mathrm{~m}$ below the ground surface. The encasement vessels are shop fabricated of 0.36 - and 0.61-m-dia pipe joined by a standard pipe reducer. The vessel is closed at the bottom by a pipe cap welded onto the 0.36 -m-dia lower section. Each drywell encasement vessel is furnished with a carbon steel plate that is field-welded to the top of the vessel after placement of the waste canister and sand. The closure plate is furnished with lifting lugs and a sample valve assembly to obtain air samples and measure pressure inside the drywell. The sample valve is protected by a detachable weather cover, and a nameplate is provided on top of the closure plate for identification. A reusable metal cover is used to protect the empty drywell from the weather before canister placement. 


\subsubsection{Postulated Upper-Bound Accident}

It is postulated that the transporter does not correctly align the waste capsule in the drywell and moves with the capsule still partially in the transporter. The transporter shears the capsule and causes subdivision and dispersion of the particles generated. The operation is performed in the open without any enclosure over the drywell, and any material release would be directly to the atmosphere.

\subsubsection{Release Estimate for Upper-Bound Event}

The dispersion value given in DOE (1982) was $1 \times 10^{-6}$ for a cover block drop, Richardson's (1980) value for a dropped shipping container was $1 \times$ $10^{-5}$. Since the area affected is less than either the container or cover block drop, the smaller value of $1 \times 10^{-6}$ is applied.

As developed in Section 5.3.1.3, one capsule contains $2.2 \times 10^{3} \mathrm{~g}$, so the release is $2.2 \times 10^{-3} \mathrm{~g}$, as listed in Table 6.12 . This release is directly to the atmosphere.

TABLE 6,12. Postulated Airborne Releases from Accidents During Drywell Storage of Waste Capsule

\begin{tabular}{|c|c|}
\hline Event & $\begin{array}{l}\text { Atmospheric } \\
\text { Airborne Release }\end{array}$ \\
\hline $\begin{array}{l}\text { Improper transporter } \\
\text { orjentation during } \\
\text { canister placement }\end{array}$ & $\begin{array}{l}2.2 \times 10^{-3} \mathrm{~g} \\
10^{-6}(\mathrm{a}) \\
\text { Fractional release }\end{array}$ \\
\hline $\begin{array}{l}\text { Package element failure/ } \\
\text { canister drop }\end{array}$ & $\begin{array}{l}10^{-5}(\mathrm{~b}) \\
\text { Fractional release }\end{array}$ \\
\hline
\end{tabular}

(a) DOE (1982).

(b) Richardson (1980). 


\subsubsection{Other Accidents Considered}

One other accident was considered and listed in Table 6.12.

Package Element Failure/Canister Drop. As stated in Doe (1982), it is not anticipated that a fully encapsulated waste container will be ruptured by routine handling mishaps. The capsules are further overpacked before disposal, even further reducing the potential for failure. It is not anticipated that the waste cantsters will fail under these conditions.

\subsection{TRU-CONTAMINATED SOIL}

Sites would be surveyed to determathe radiation and contamination status. Subsidence control is achieved by injecting grout into sites with high potential. Abandoned ponds, trenches, and ditches would be filled before covering if necessary. Trench drains, cribs, settling tanks, and reverse wells could be injected with grout.

\subsubsection{Grout Injection}

Grouting is the only disposal operation associated with the in-place stabilization and isolation alternative for these sites (Rockwell 1985).

Subsidence control is initiated by completing a geophysical survey of the high subsidence potential liquid waste sites (typically cribs) to identify their location and to identify grout injection points. To stabilize, these sites, a conceptual method is used involying a cementitious grout injected by a specially trained crew. The equipment needed includes mixing tanks, proportioning transfer pumps, hoses, and pneumatic drills. After grout injection, a construction crew is required to triin vent and feed piping with power saws under a tent-type containment. The equipment and personnel are transported by heavy-duty trucks. Following grout injection, the surface barrier can be applied (Rockwell 1985).

\subsubsection{Postulated Upper-Bound Accident}

The upper-bound airborne release event is suggested by Murphy and Holter (1980). This is a void space collapse initiated by equipment. They postulated 
that an earthmover was engulfed in a $90 \mathrm{~m}^{3}$ void space. This disturbed $45 \mathrm{~m}^{3}$ of waste for an hour and produced airborne material.

\subsubsection{Release Estimate for Upper-Bound Release Event}

In the event postulated by Murphy and Holter (1980), the source was $130 \mathrm{Ci}$ and $4.7 \times 10^{-3} \mathrm{Ci}$ is released; thus, the calculated atmospheric fractional release is $3.6 \times 10^{-5}$. At a soil density of $1.8 \mathrm{~g} / \mathrm{cm}^{3}$, the $45 \mathrm{~m}^{3}$ is $8.1 \times$ $10^{7} \mathrm{~g}$, and the calculated release is $2.9 \times 10^{3} \mathrm{~g}$. Onily a portion will be in the respirable size range. As discussed in Section 5.4.1.3, Hanford soil can have a $0.088 \%$ respirable component. This makes the release of concern $2.6 \mathrm{~g}$, as listed in Table 6.13.

\subsubsection{Other Accidents Considered}

Other accidents considered are also listed in Table 6.13.

Grout Ejection. Grout injection at an excessive rate could possibly result in some minor amounts of waste being ejected through the air exhaust. If an air exit is not provided, pressure bujldup could potentially eject some of the waste through the entry chute.

Excavating Contaminated Soil. Disturbing contaminated soil during excavation before marker placement should not be likely since clean material covers the waste to a depth of $5.4 \mathrm{~m}$. Radiation surveys should preclude this accident.

TABLE 6.13. Postulated Airborne Release from Accidents During Grout Injection

Event
Void space collapse
Grout ejection
Digging into waste
Fire
Reaction with concrete
Excavating contaminated
soil

\author{
Atmospheric \\ Airborne Release \\ $2.6 \mathrm{~g}$ \\ Significantly below \\ upper-bound \\ No significant release \\ No significant release \\ No significant release \\ No significant release
}


Digging Into Waste. Digging into waste should not be likely, since little digging will be done. The method of preparing the grout injection has not been detafled, but it would probably be sore of a core drilling operation than digging. The radiation surveys should preclude this accident.

Fire. Fire would be a limited event since there is a low level of conbustible material in the cribs. The wood-constructed cribs could possibly burn, but no significant releases are postulated.

Reaction with Concrete. Thermal or reactive interaction of waste with the concrete does not seem likely. Small amounts of contained organics might have been inadvertently included when the waste was interred, but should not be in amounts larye enough to be of concern.

\subsection{PRE-1970 SOLID TRU WASTE}

Pre-1970 TRU solid waste burial grounds would be stabilized as required.

\subsubsection{Grout Caissons}

Caissons containing TRU waste would be immobilized in place by being filled with grout or other stable fillers. The area would then be covered and marked.

\section{5 .1 .1 Deseription of Operation}

A conceptual method of injecting cenentitious grout into caissons has been developed (Rockwell 1985). This is the same method Rackwell suggested for TRUcontaminated soil sites, described here in section $6.4,1$.

\subsubsection{Postulated Upper-Bound Accident}

For caissons, void space collapse does not seen to apply, since the waste is confined to the caisson. The postulated upper-bound event is equipnent malfunction allowing grout injection at an excessive rate. This could result in an eruption of contaminated aterial through the air inlet. The waste could be from a package broken during placement. Surface contamination could contribute to the release. Some material is assumed to be ejected into the air, and the 
potential for resuspension could also be considered. Since the caissons are located $4 \mathrm{~m}$ below grade, it seems unlikely that a large quantity of waste could be ejected.

\subsubsection{Release Estimate for Upper-Bound Event}

Haste should be packaged in the caisson. For this release estimate, it is postulated that the waste is stored in 3.82-L metal cans. It is assumed that the contents of one can are involved in the accident. The fractional release is assumed to be similar to that from a core drilling accident described by Murphy and Holter $(1980), 7 \times 10^{-8}$. At a waste density of $0.96 \mathrm{~g} / \mathrm{cm}^{3}$, the source is $3.7 \times 10^{3} \mathrm{~g}$ and the release would be about $3 \times 10^{-4} \mathrm{~g}$ as 1 isted in Table 6.14. It would appear that only airborne material reaches the surface, so that there is no source for resuspension releases.

\subsubsection{Other Accidents Considered}

These accidents are also listed in Table 6.14.

Void Space Collapse. A void space collapse would not seem to apply to this situation, since the waste is confined to the caisson.

Spread of Surface Contamination. Surface contamination spread could only result in minor releases, which could occur if hoses are introduced into a contaminated chute and then withdrawn. Details of the operation not currently available could suggest whether this is a real possibility.

\section{TABLE 6.14. Postulated Airborne Releases from Accidents During Grout Injection of Caissons}

\begin{tabular}{|c|c|}
\hline Event & Airborne Release \\
\hline $\begin{array}{l}\text { Injection at excessive } \\
\text { rate }\end{array}$ & $3 \times 10^{-4} \mathrm{~g}$ \\
\hline Void space collapse & $\begin{array}{l}\text { No significant } \\
\text { release }\end{array}$ \\
\hline $\begin{array}{l}\text { Spread of surface } \\
\text { contamination }\end{array}$ & $\begin{array}{l}\text { No significant } \\
\text { release }\end{array}$ \\
\hline
\end{tabular}

Fires 
Fire, Fire such as a range fire is possible, but the depth of burial should preclude the possibility of releases from this event.

\subsubsection{Subsidence Control}

A plle-driving method is currently being developed for subsidence control in areas with high potential for subsidence (Rockwell 1985).

\section{5 .2 .1 Description of pperation}

Plles are injected into identified waste zones using a diesel-powered vibratory hamer/extractor attached to a vibratory crane. The 5-m-long plles are driven at 2.5-m centers within identified areas. Piles are dynamically driven through the waste zone and then withdrawn.

If the piles are found to have smearable surface contanination when withdrawn, they are redriven to grade. If no smearable contamination is detected, the plles are withdrawn and reused.

\section{5 .2 .2 Postulated lpper-gound Accident}

The postulated upper-bound release event is a void space collapse described in Section 6.4 .1 .2 with the same estimated release, $2.6 \mathrm{~g}$. The release is listed in Table 6.15.

\section{5 .2 .3 Other Accidents Considered}

No significant releases were postulated for the events listed in Table 6.15.

TABLE 6.15. Postulated Airborne Releases from Accidents During Subsidence Control

\begin{tabular}{ll}
\multicolumn{1}{c}{ Event } & \multicolumn{1}{c}{ Aroorne Release } \\
Void space collapse & 2.69 \\
Fenetration of waste & No significant release \\
Fire & No significant release \\
Excavating contaminated soil & No significant release \\
Criticality & Not postulated
\end{tabular}


Penetration of Haste. Penetration of waste during rod emplacement could lead to releases when the rod is withdrawn. The dianeter of the rods would be fairly small, so no large amount of waste would be available as a release source. When the waste is penetrated it is probably displaced and imnobilized, and only small amounts clinging to the rod would reach the surface.

Fire. Fire could be considered, for example, if a range fire engulfed the diesel-operated vibratory hamer. The fire would be very limited because of low combustible loading, and should not result in releases of airborne contamination.

Excavating Contaminated Soil. The only soil excavation is done during marker placement. This is not a likely source of radioactive release since clean material is covering the waste to a depth of $5.4 \mathrm{~m}$.

Criticality. Subsidence control is an operation to examine for criticality potential. While administrative controls should have prevented criticality during interment, this operation will change the fissile geometry within the soil matrix since the vibratory hammer will compress soil and waste. This type of system (soil, waste) does not tend to produce criticalities; they generally occur in solution systems with material accumulation in a tank and a surge to unsafe geometry. Nevertheless, Clayton (1974) suggests that criticality can occur in soil with concentrations as low as $2 \mathrm{~g} / \mathrm{L}$ in relatively dry soil. He also suggests soil as having a $30 \%$ void volume; thus if soil with $2 \mathrm{~g} / 1.4 \mathrm{~L}$ is compressed to $2 \mathrm{~g} / \mathrm{L}$ it is a geometry that could conceivably go critical. Soils surrounding the packaged waste could be contaminated from leakage or ruptured packages. It is unlikely that there would be sufficient fissile material available to sustain a criticality. Radiation surveys should preclude criticality accidents.

\subsection{RETRIEVABLY STORED ANO NEHLY GENERATED TRU SOLID WASTE}

Any TRU solid waste packages stored in above-grade facilities would be buried. All retrievably stored TRU solid waste would be treated the same as pre-1970 TRU solid waste. Thus the only releases not covered in section 6.5 
are from the burial operations. The subsidence control releases were included in Table 6.15, with the upper-bound release identified as the void space collapse.

\section{6 .1 Waste Burial}

Burtal operations are performed routinely at hanford, thus are not detalled in either the Hanford Defense Waste Envilonmental Impact Statement or the support document for retrievably stored and newly generated transuranit solid waste (Rockwell 1985 ).

\section{6 .1 .1 Description of operation and Facility}

Routine disposal of non-TRU waste by buriat in trenches at Hanford is described by eiger, Brown and Isacson (1977). It is assumed that the process used here will be similar. Therefore, the waste would be placed in a wide-top, relatively narrow-bottom trench. All radioactive waste is covered at the end of the day. No enclosure is ldentified for the operation.

\section{6 .1 .2 Postulated Ugper-Bound Accjdent}

The accident occurring when the waste container is in the open air rather than covered with dirt would have the largest release potential. A breach of a waste container, spilling the contents in the ambient atr, is the postulated upper-bound accident.

\subsubsection{Release Estinate for Upper-Bound Event}

Based on the experinental work of Sutter (1980), 5\% of the spilled waste could be entrained if the ambient winds are at the Hanford average 7.6 mph (Stone et al. 1972). The waste will be in 210-L drums, and at a waste density of $0.96 \mathrm{~g} / \mathrm{cm}$ has a total mass of $2 \times 10^{5} \mathrm{~g}$. The total is $1 \times 10^{3} \mathrm{~g}$ released directly to the atmosphere.

\section{6 .1 .4 Qther Accidents considered}

The other accidents constdered before selecting the upper-bound release are discussed below and listed in Table 6.16.

Puncture. A puncture-type penetration of the waste container would have a tower release than would a complete breach of the container. 
TABLE 6.16. Postulated Airborne Releases from Accidents During Subsidence Control

\begin{tabular}{lc}
\multicolumn{1}{c}{ Event } & \multicolumn{1}{c}{$\begin{array}{c}\text { Atmospheric } \\
\text { Airborne Release }\end{array}$} \\
$\begin{array}{l}\text { Container Breach } \\
\text { Puncture }\end{array}$ & $\begin{array}{l}1 \times 10^{3} \mathrm{~g} \\
\text { Significantly below } \\
\text { upper-bound }\end{array}$ \\
Equipment Impact & $\begin{array}{c}\text { Significantly below } \\
\text { upper-bound }\end{array}$ \\
Fire & No significant release
\end{tabular}

Equipment Impact. Equipment impacting the waste, if it generated sufficient energy to break a package, would not result in a release above the level estimated above for the upper-bound event.

Fire. Fire would be unlikely since the waste is packaged so that air is available. During this operation there is primarily dirt on the surface, and no combustibles are available, so a range fire is unlikely. 


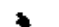

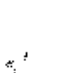

$i$

$+$ 


\subsection{POSTULATED RELEASES FROM OPERATIONAL ACCIOENTS ASSOCIATED WITH REFERENCE DISPOSAL OF SIX WASTE FORMS}

The reference alternative provides a balanced disposal approach to the waste disposal. This alternative should limit long-term (over 10,000 yr) population risk without incurring near-term risks by disturbing wastes that are now stable.

To some extent, the reference alternative would combine geologic disposal and inmplace stabilization and disposal. It would be the same as the geologic disposal alternative for strontium and ceslum capsules and portions of retrieyably stored and newly generated TRU solid waste. It would be the same as the in-place stabilization and disposal alternative for waste in single-shell tanks, TRU-contaninated soil sites, and pre-1970 TRU buried solld waste sites. Table 7.1 lists the waste forms and indicates disposal alternative techniques that are applicable to each. Operational accidents will not be discussed again here, so the third column lists the report section in which they are developed. All upper-bound operational releases are listed in Table 7.2 for quick reference.

Thus there are three waste classes or portions thereof that could involve some variation of aperationdl steps as listed below.

- Double-shell tank waste: grouted liquid waste could be returned to empty tanks

- Future tank waste: cesium removal only

- Retrievable remote-handled TRU: packaged for geologic disposal.

These wastes would be processed in facilities sized for the need of the reference alternative, rather than in the more extensive and much larger factlities required for the geologic disposal alternative.

\subsection{DQUBLE-SHELL TANK WASTE}

Operations for the double-shell tank wastes are essentially the same as those described in Section 5.1. Steps are hydraulic retrieval, sludge washing, high-level and TRU separation (without technetium or strontium recovery), 
TABLE 7.1. Reference Disposal Techniques for Six Waste Forms

Waste Form

Existing tank waste
Single-shell
Double-shell
Future tank waste
Strontium and cesium
capsules
TRU-contaminated soil
Pre-1970 solid waste
Retrievably stored and
newly generated TRU
Contact-Handled TRU
Remote-Handled TRU

Applicable Alternative Disposal Method
Report Section Developing Accidents

\section{In-place stabilization and $\quad 4.1$ disposal
Geologic, part repository and
3.1 part onsite}

New

Geologic

In-place stabilization $\quad 4.4$ and disposal

In-place stabilization $\quad 4.5$ and disposal

Geologic 3.6

New

vitrification, and repository disposal. Some operations will be conducted in a small vitrification facility, but will be the same as geologic disposal. For example, vitrification will use a joule-heated melter. Accidents and releases will be the same as Section 5.1, and are listed in Table 7.2.

\subsection{FUTURE TANK HASTE}

The reference alternative for future tank waste involves geologic disposal of high-level waste. Cesium only would be removed from neutralized current acid waste before grouting. Strontium and TRU elements from this waste would be contained primarily in the sludge. Cesium and the sludge would be vitrified. Accidental releases from all of these operations were developed in Section 5.1 and are listed in Table 7.2. 
TABLE 7.2. Reference AIternative Potential Accidental Releases for Operations Involving Six Waste Forms

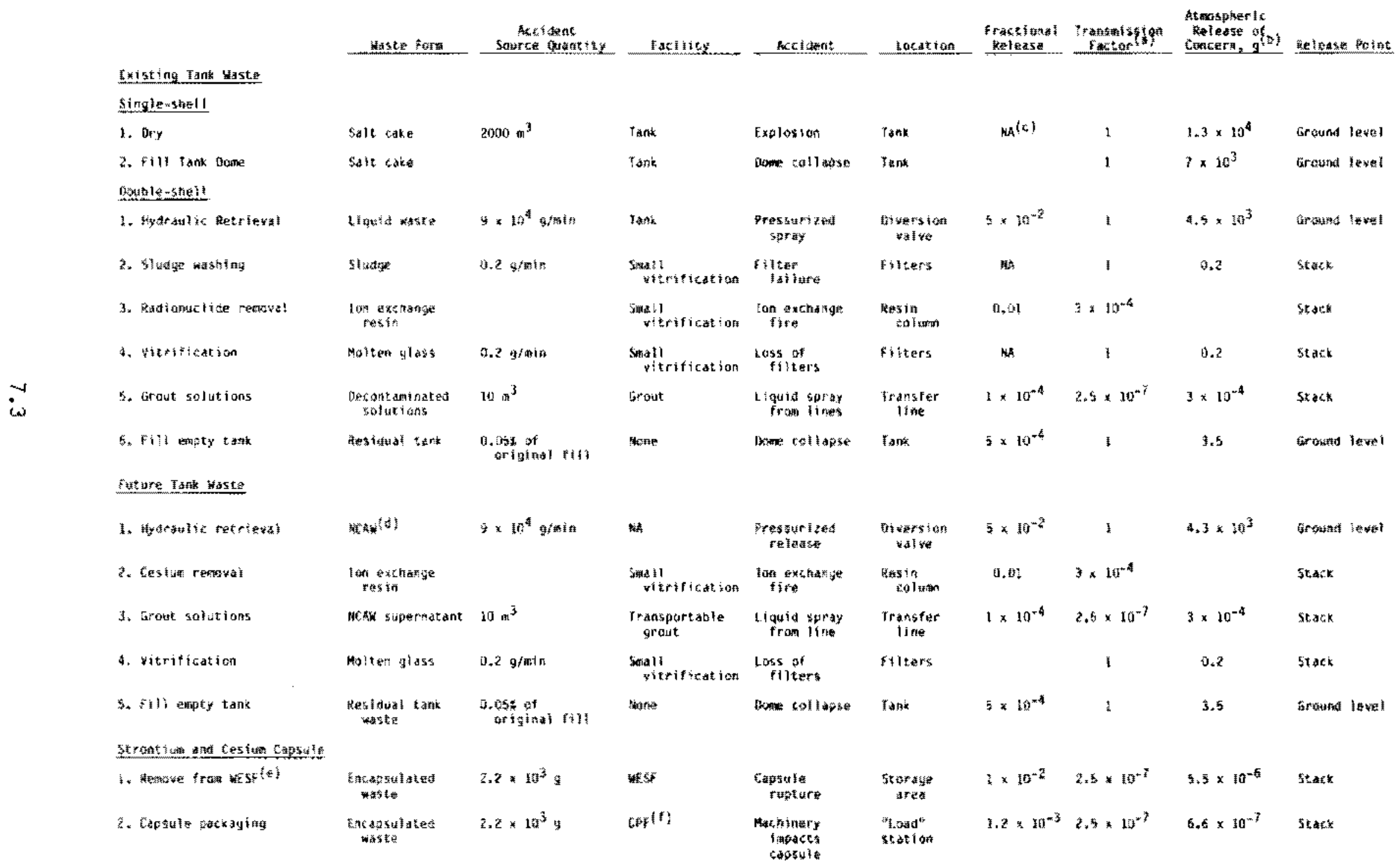


TABLE T.2. (contd)

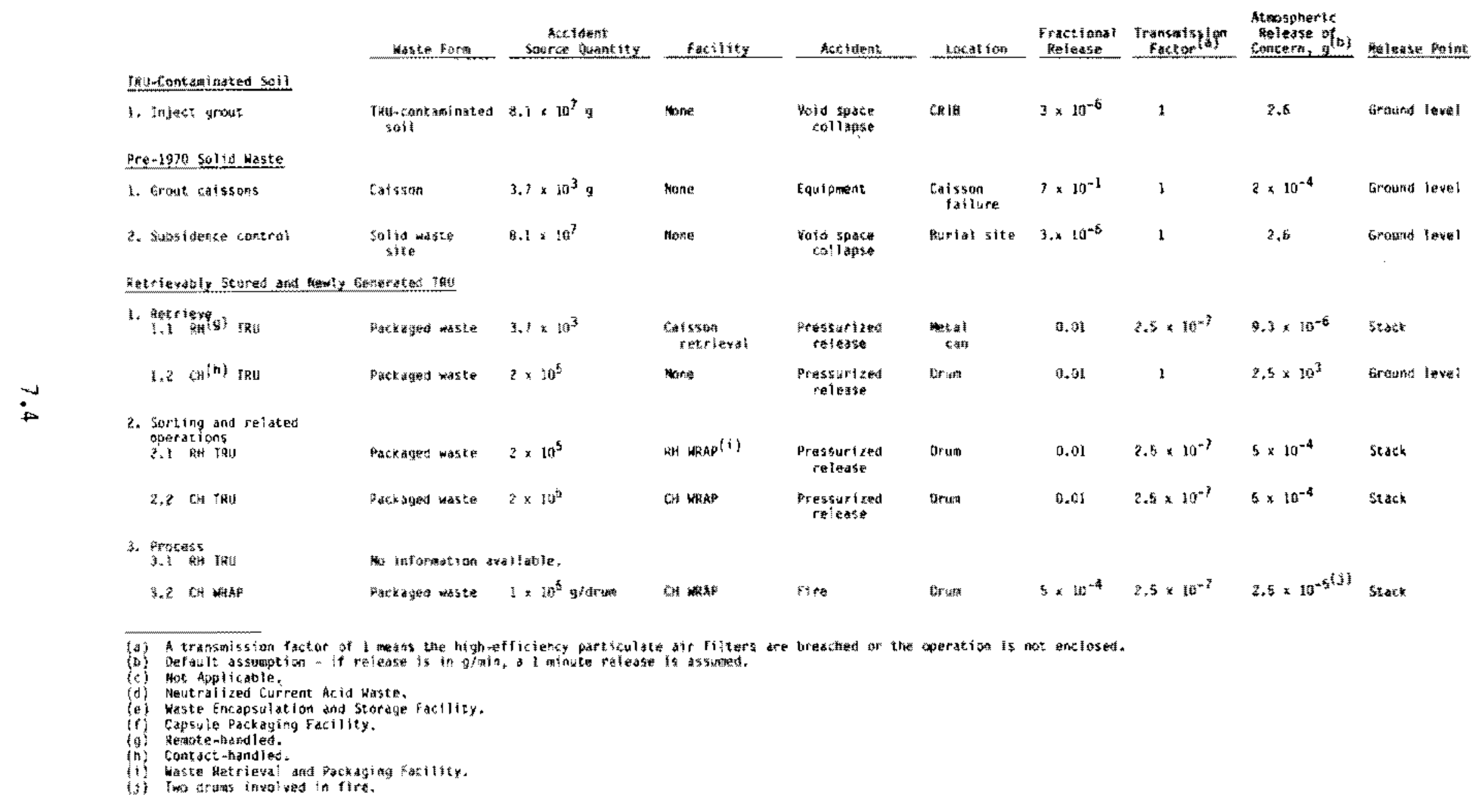




\subsection{RETRIEVABLY STORED AND NEWL.Y GENERATED TRU}

For the reference alternative, retrievably stored and newly generated TRU would be sent to a geologic repository. The waste would be processed in the same way as in the geologic disposal alternative, except for the remote-handled TRU waste. Since only remote-handled TRU waste would be processed, a smaller factlity would be used. The waste processing facility proposed for the geologic disposal alternative was sized to accomodate TRU-contaminated soil sites and pre-1970 TRU solid waste burial grounds,

The remote-handled TRU waste would be processed in a fatility that provides remote handling, and contains hot cells for size reduction, ianobilization, and packaging, A remote-handled waste retrieval and packaging facility would include specific processes required to imnobilize and package the waste (Rockwell 1985). However, the imobilization process is not identffied, so no releases can be developed. Table 7.2 lists the postulated reledses from the other operations. 


\subsection{POSTULATED RELEASES FROM OPERATIONAL ACCIDENTS ASSOCIATED WITH THE NO DISPOSAL ACTION ALTERNATIVE}

Under the no disposal action, the wastes are placed in continued storage; this alternative does not implement a long-term solution for permanent disposal of the radioactive wastes. The wastes would continue to be stored essentially as they are now for the indefinite future. The waste-handling operations would include storage, necessary remedial actions, and waste surveillance. The accidents postulated for this alternative process are shown in Table 8.1. They involve the double-shell wastes (both existing and future tank wastes), the strontium and cesium capsules, and all TRU wastes. With the exception of the existing tank wastes and the retrievably stored and newly generated TRU, upperbound accidents have been described in Sections 5.0, 6.0, and 7.0. For the existing tank wastes, the ferrocyanide explosion is no longer postulated to occur, as the single-shell tank wastes are left undisturbed. The dominant release for this waste class then becomes the pressurized release during hydraulic transfer of the existing double-shell tank wastes from tank to tank as required to assure tank integrity. For the retrievably stored and newly generated TRU, the collapse of a void space, similar to that described for the other TRU sites, is postulated to occur during subsidence control. 
TABLE 8.1. No Disposal Action Alternative Accidental Releases for Operations Involving Six waste Foras

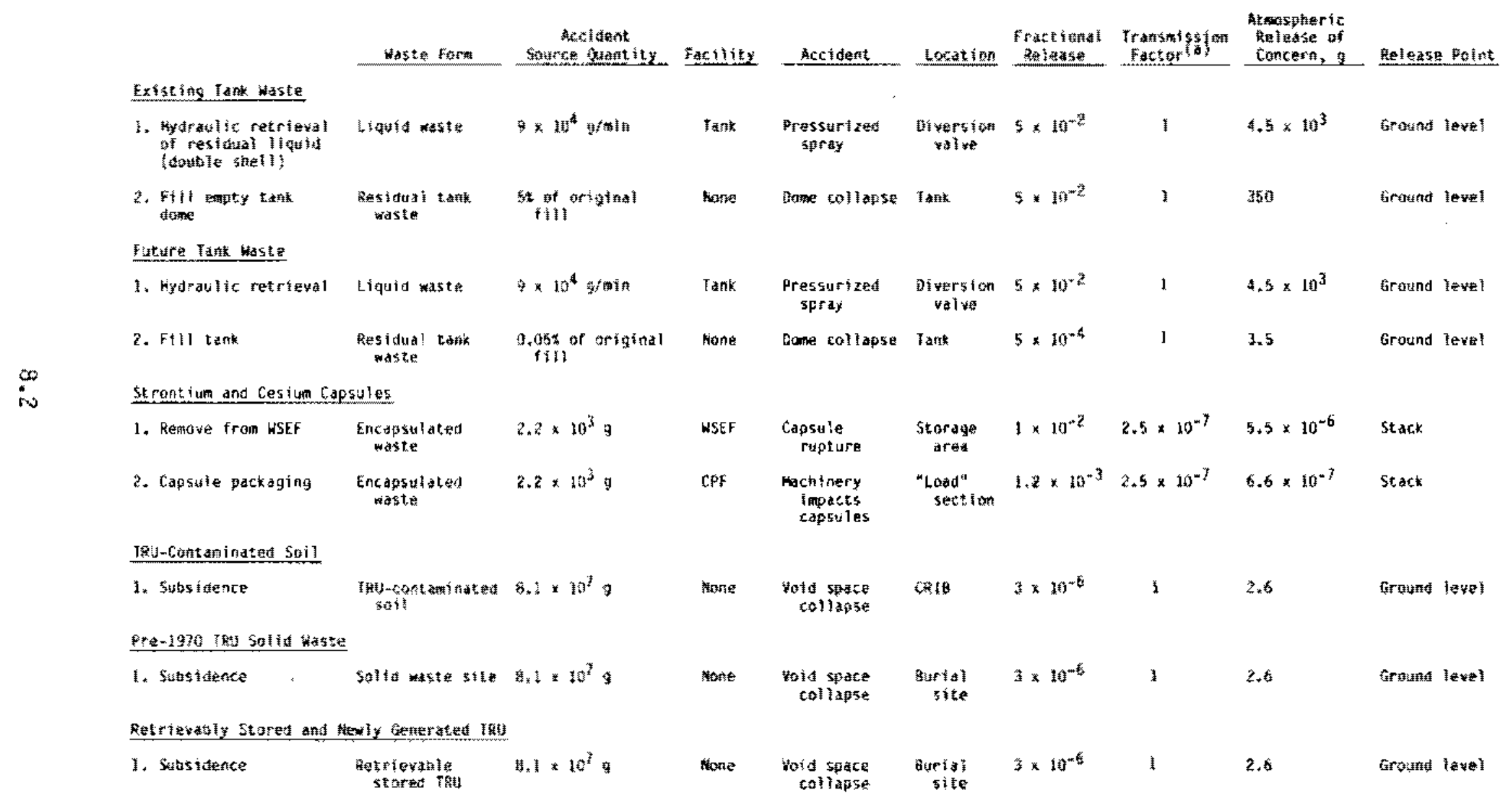

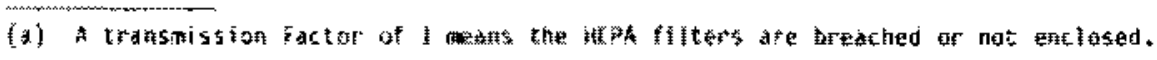




\subsection{REFERENCE RADIONUCLIDE INVENTORIES}

Reference radionuclide inventories used to conservatively estimate potential radiation doses to the public from operational accidents during proposed waste disposal operations are covered in this section. These reference inventories represent the upper bound or maximum radionuclide inventory or concentration anticipated during these operations. The inventories are calculated from the data supplied by Rockwell either in their engineering data packages (Rockwell 1985) or by subsequent memoranda (Rockwell 1985b) or conversations with cognizant technical staff. Flowsheets are currently unavailable to adequately define the modification of the inventories during the various operations and, therefore, no credit is taken for the dilution or concentration of waste until it is processed into its final disposal form.

\subsection{EXISTING TANK WASTE INVENTORIES}

Existing tank waste is presently stored as salt cake, sludge, interstitial liquors (double-shell tank slurries) and complex concentrates. Existing tank waste in 149 older single-shell tanks and 20 new double-shell tanks contain the bulk of the radioactive waste $\left(1.8 \times 10^{5} \mathrm{~m}^{3}\right)$ stored on the Hanford site (Rockwell 1985).

\subsubsection{Tank or Process Waste Inventories}

To generate a reference radionuclide inventory that would represent near upper-bound concentration levels of radionuclides for existing tank waste, the C-105 tank with the highest measured TRU concentration levels was selected as the reference waste. The $\mathfrak{C}-105$ tank radionuclide concentrations are shown in Table 9.1. This reference inventory is used to estimate the potential radiological impacts on the public from accidents postulated to occur during the handling, packaging and processing operations for existing tank waste.

\subsubsection{Grout and Glass Inventories}

Average concentrations of radionuclides in grout and glass for existing tank waste are shown in Table 9.2 for the three disposal alternatives. These data are taken from a Rockwell engineering package (Rockwel1 1985) and 
TABLE 9.1. Estimated Upper Bound Tank Inventory of Radianuclides for Existing Waste (Decayed to the end of 1990)

\begin{tabular}{|c|c|c|}
\hline Radionuclide & $\mathrm{Ci}$ & $\mathrm{Ci} / \mathrm{kg}^{(\mathrm{a})}$ \\
\hline $241_{\mathrm{An}}$ & $1 \times 10^{4}$ & $1 \times 10^{-2}$ \\
\hline $243_{\mathrm{An}}$ & $1 \times 10^{1}$ & $1 \times 10^{-5}$ \\
\hline${ }^{14} \mathrm{C}$ & $6 \times 10^{2}$ & $7 \times 10^{-4}$ \\
\hline $244 \mathrm{cn}$ & $6 \times 10^{1}$ & $7 \times 10^{-5}$ \\
\hline $135 \mathrm{Cs}$ & $8 \times 10^{-1}$ & $1 \times 10^{-6}$ \\
\hline $137 \mathrm{Cs}$ & $2 \times 10^{5}$ & $2 \times 10^{-1}$ \\
\hline $129 \mathrm{I}$ & 2 & $2 \times 10^{-5}$ \\
\hline $63_{\mathrm{Ni}}$ & $4 \times 10^{4}$ & $5 \times 10^{-2}$ \\
\hline $237 \mathrm{~Np}$ & $6 \times 10^{-2}$ & $7 \times 10^{-8}$ \\
\hline $238 \mathrm{pu}$ & $5 \times 10^{1}$ & $6 \times 10^{-5}$ \\
\hline $239 \mathrm{Pu}$ & $2 \times 10^{3}$ & $2 \times 10^{-3}$ \\
\hline $240 p_{u}$ & $6 \times 10^{2}$ & $7 \times 10^{-4}$ \\
\hline $241_{\mathrm{p}_{\mathrm{A}}}$ & $5 \times 10^{3}$ & $6 \times 10^{-3}$ \\
\hline $226_{\mathrm{Ra}}$ & $9 \times 10^{-9}$ & $1 \times 10^{-14}$ \\
\hline $106_{\mathrm{Ru}}$ & 5 & $6 \times 10^{-6}$ \\
\hline $151_{5 \times 1}$ & $1 \times 10^{5}$ & $1 \times 10^{-1}$ \\
\hline $1265 n$ & $9 \times 10^{1}$ & $1 \times 10^{-4}$ \\
\hline $90_{S r}$ & $3 \times 10^{6}$ & 4 \\
\hline $99_{\mathrm{TC}}$ & $1 \times 10^{3}$ & $1 \times 10^{-3}$ \\
\hline${ }^{2} 30_{\mathrm{Th}}$ & $1 \times 10^{-6}$ & $1 \times 10^{-12}$ \\
\hline $233 \mathrm{v}$ & $3 \times 10^{-4}$ & $4 \times 10^{-10}$ \\
\hline $234 \mathrm{u}$ & $7 \times 10^{-3}$ & $8 \times 10^{-9}$ \\
\hline $235 \mathrm{v}$ & 1 & $1 \times 10^{-6}$ \\
\hline $238 \mathrm{v}$ & $2 \times 10^{1}$ & $2 \times 10^{-5}$ \\
\hline $93 \mathrm{zr}$ & $5 \times 10^{2}$ & $6 \times 10^{-4}$ \\
\hline
\end{tabular}

(a) Based on C-105 tank inventory (Rockwell 1985). $150,000 \mathrm{gal}$ (sp gr 1.4) $835,000 \mathrm{~kg}$ waste. 


\section{TABLE 9.2. Average Concentration of Radionuclides in Grout and Glass from Existing Tank Waste}

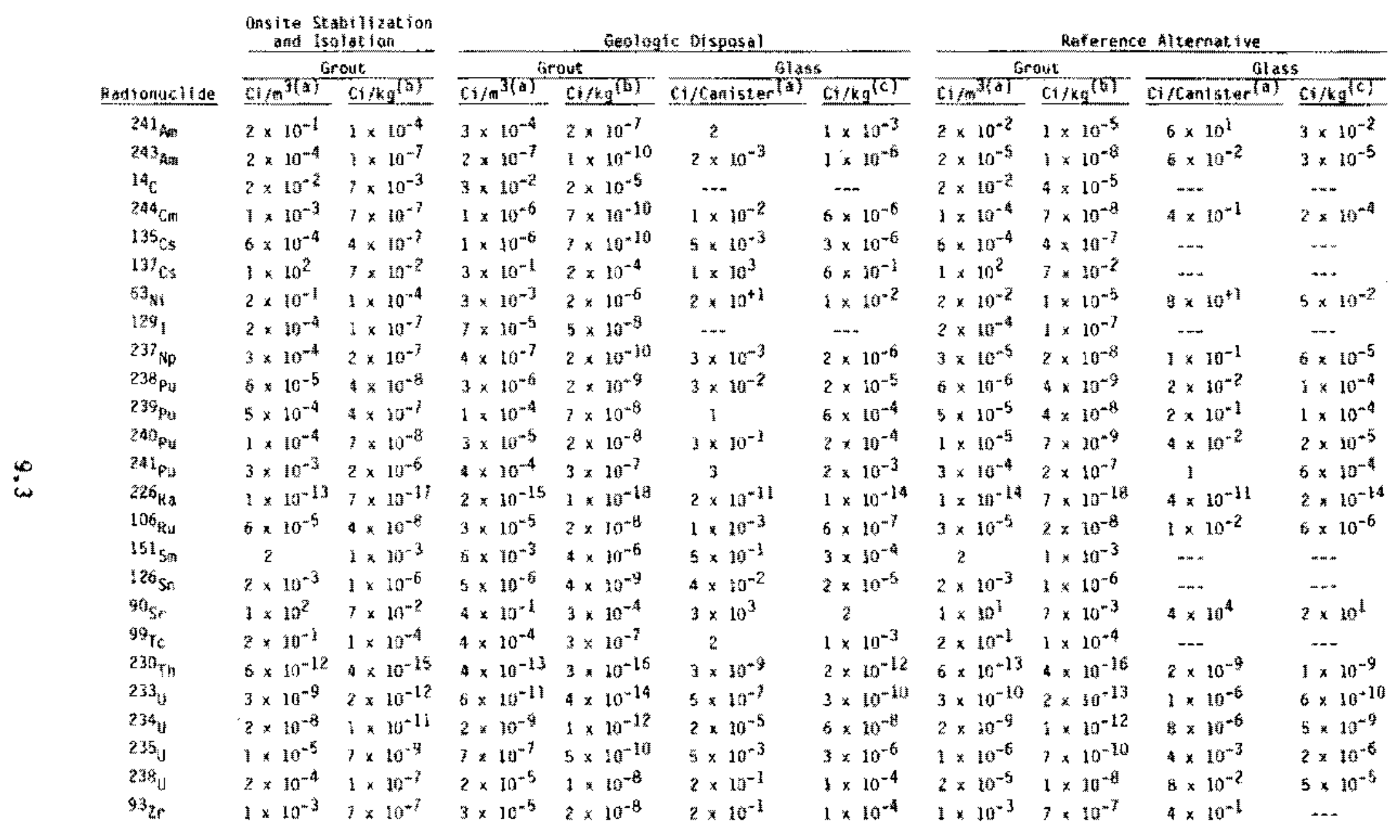

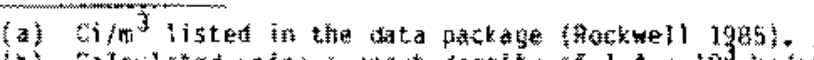

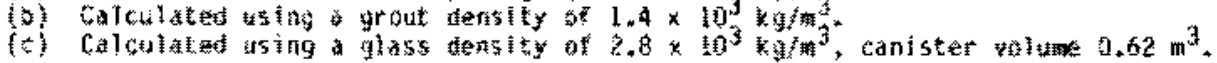


converted to $61 / \mathrm{kg}$ of grout or glass. Grout densities can range in values from 1.27 to $1.43 \mathrm{~g} / \mathrm{cm}^{3}$ (Mcoaniel and Moore 1981, Table 111). A value of $1.4 \mathrm{~g} / \mathrm{cm}^{3}$ $\left(1.4 \mathrm{~kg} / \mathrm{m}^{3}\right)$ was selected to calculate grout concentrations. Mendel et al. (1981, p. 2.2) compiled a list of glass waste densities. Values for borosilicate glass ranged from 2.6 to $3.4 \mathrm{~g} / \mathrm{cm}^{3}$. We calculated glass concentration using a $2.8 \mathrm{~g} / \mathrm{cm}^{3}\left(2.8 \mathrm{~kg} / \mathrm{m}^{3}\right)$ walue. Average concentration values are used for grout and glass since the waste is processed and blended prior to grouting or vitrification operations.

\subsection{FUTURE TANK WASTE - REFERENCE RADIONUCLIOE INUENTORIES}

Thts section describes the radionuclide composition of new waste from the processing of N-Reactor fuel fn the PUREX facility and the planned operation of the Plutonium Finishing Plant. Estinates of the radionuclide concentrations in high-level waste fron N-Reactor produced fuels from $F-1972$ through Fy-1990 for fission products, actinides, and activation products are shown in Table 9.3a. These inventories are accumulated to the end of F-1990, then decayed annually through 1995. Table 9.3b lists cladding removal waste values. For dose calculations the larger inventory $N$-Reactor or cladding removal waste value is used. The concentrations reported represent the waste neutralized and accumulated before a ytrification facillty is ayallable in $F y-1991$ for the refarence option. plutonium finishing plant wastes, processed separately, have tRu concentrations lower by a factor of 2 to 3 than those shown for the puREX wastes and use of the PuRE concentrations in the calculations of the radiological impacts will generate bounding values. Thus, plutonium finishing plant waste concentrations are not listed.

The average concentrations of radionuclides in grout and glass for new tanked waste is shown in Table 9.4 for the three disposal alternatives. These data are taken from Rockwell (1985) and converted to cllkg of grout or glass. Average concentrations values are used for grout or glass since the waste is processed and blended prior to grouting or vitrification. 
TABLE 9.3a. Radioisotopes Accumulated in PUREX High Level waste from N-Reactor Production FY-1972 to FY-1990 and Decayed through FY-1995

\section{Fission Products}

\begin{tabular}{|c|c|c|}
\hline Radionuclide & $\mathrm{Cj}(\mathrm{a})$ & $\mathrm{Ci} / \mathrm{kg}^{(\mathrm{b}}$ \\
\hline${ }^{144} \mathrm{Ce}$ & $1.29 \times 10^{8}$ & $2 \times 10^{-1}$ \\
\hline${ }^{134} \mathrm{Cs}$ & $4.97 \times 10^{5}$ & $4 \times 10^{-2}$ \\
\hline${ }^{137} \mathrm{Cs}$ & $4.44 \times 10^{7}$ & 7 \\
\hline${ }^{154} \mathrm{Eu}$ & $1.64 \times 10^{5}$ & $1 \times 10^{-2}$ \\
\hline $155_{E u}$ & $8.94 \times 10^{4}$ & $7 \times 10^{-3}$ \\
\hline $3_{H}$ & $7.2 \times 10^{3}$ & $6 \times 10^{-4}$ \\
\hline${ }^{129} \mathrm{I}$ & $1.21 \times 10^{1}$ & $1 \times 10^{-6}$ \\
\hline $106_{\text {RuRh }}$ & $2.5 \times 10^{7}$ & 2 \\
\hline $125 \mathrm{Sb}$ & $7.14 \times 10^{5}$ & $6 \times 10^{-2}$ \\
\hline${ }^{151} \mathrm{Sm}$ & $3.94 \times 10^{5}$ & $3 \times 10^{-2}$ \\
\hline${ }^{126} \mathrm{Sn}$ & $2.2 \times 10^{1}$ & $2 \times 10^{-6}$ \\
\hline${ }^{90} \mathrm{Sr}$ & $4.08 \times 10^{7}$ & 3.5 \\
\hline${ }^{99} \mathrm{Tc}$ & $4.7 \times 10^{3}$ & $4 \times 10^{-4}$ \\
\hline${ }^{93}$ ZrNb & $1.9 \times 10^{3}$ & $2 \times 10^{-4}$ \\
\hline
\end{tabular}

Actinides

$\begin{array}{cccc}\text { Radionuclide } & \frac{C i(a)}{241_{\mathrm{Am}}} & \frac{\mathrm{Ci} / \mathrm{kg}^{(\mathrm{b})}}{1.99 \times 10^{5}} & 2 \times 10^{-2} \\ 239_{\mathrm{Pu}} & 2.07 \times 10^{3} \cdot 2 \times 10^{-4} \\ 240_{\mathrm{Pu}} & 4.41 \times 10^{2} & 4 \times 10^{-5} \\ 241_{\mathrm{Pu}} & 1.92 \times 10^{4} & 2 \times 10^{-3} \\ 235_{\mathrm{U}} & 2.06 \times 10^{-1} & 2 \times 10^{-8} \\ 238_{\mathrm{U}} & 4.03 & 3 \times 10^{-7}\end{array}$

Activation Products

\begin{tabular}{|c|c|c|}
\hline Radionuclide & $\mathrm{Ci}(\mathrm{a})$ & $\mathrm{Cj} / \mathrm{kg}^{(\mathrm{b})}$ \\
\hline $14 \mathrm{C}$ & $1.9 \times 10^{2}$ & $2 \times 10^{-5}$ \\
\hline${ }^{60} \mathrm{Co}_{0}$ & $2.58 \times 10^{5}$ & $2 \times 10^{-2}$ \\
\hline${ }^{55} \mathrm{Fe}$ & $2.42 \times 10^{4}$ & $2 \times 10^{-3}$ \\
\hline${ }^{54} \mathrm{Mn}$ & $2.3 \times 10^{3}$ & $2 \times 10^{-4}$ \\
\hline $95 m_{\text {Nb }}$ & $3.6 \times 10^{-3}$ & $3 \times 10^{-10}$ \\
\hline $59 \mathrm{Ni}$ & $4.3 \times 10^{1}$ & $4 \times 10^{-6}$ \\
\hline $63 \mathrm{Ni}$ & $3.9 \times 10^{3}$ & $3 \times 10^{-4}$ \\
\hline $125_{\mathrm{Sb}}$ & $4.6 \times 10^{1}$ & $4 \times 10^{-6}$ \\
\hline${ }^{11} 3_{5 n}$ & 4.75 & $4 \times 10^{-7}$ \\
\hline $119 m_{S n}$ & $9.07 \times 10^{1}$ & $7 \times 10^{-6}$ \\
\hline $121 m_{5 n}$ & $6.76 \times 10^{-2}$ & $6 \times 10^{-9}$ \\
\hline $93 \mathrm{Zr}$ & $7.65 \times 10^{-7}$ & $6 \times 10^{-14}$ \\
\hline${ }^{95} \mathrm{Zr}$ & $3.4 \times 10^{-3}$ & $3 \times 10^{-10}$ \\
\hline
\end{tabular}

Quantity of Fuel Processed: 12,144 MTU

Note: Combined activities are listed for isotope pairs. No contingency included.

(a) Ci listed in Rockwell (1985)

(b) Volume $800 \mathrm{~L} / \mathrm{MTU}$; sp gr 1.25 at $20^{\circ} \mathrm{C}$ information obtained from Bob Watrous, Rockwell, February 6, 1984 
TARLE 9.3b. Radioisotopes Accumulated by FY 1995 in Cladding Removal Waste from N-Reactor Production, FY 1972 throuth Fy 1995

Fission Products

\begin{tabular}{|c|c|c|}
\hline 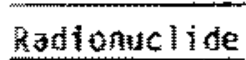 & Gita) & cilkg (b) \\
\hline $144_{\text {Ce }}$ & $1.29 \times 10^{5}$ & $2 \times 10=\frac{7}{2}$ \\
\hline $134_{\mathrm{cs}}$ & $1.49 \times 10^{4}$ & $1 \times 10^{-3}$ \\
\hline $137_{55}$ & $1.33 \times 10^{6}$ & $2 \times 1 n^{* 1}$ \\
\hline $154 \mathrm{Eu}$ & $1.64 \times 10^{2}$ & $1 \times 11^{-5}$ \\
\hline $155_{\mathrm{EU}}$ & $0.94 \times 10^{1}$ & $7 \times 10^{-6}$ \\
\hline $106 R_{\mathrm{Ru}}$ & $7.50 \times 10^{5}$ & $6 \times 10^{-2}$ \\
\hline $124 \mathrm{SO}$ & $2.14 \times 10^{4}$ & $2 \times 10^{-3}$ \\
\hline${ }^{151} \mathrm{l}_{\mathrm{Sm}}$ & $3.94 \times 10^{2}$ & $3 \times 10^{-4}$ \\
\hline $126_{\mathrm{Sn}}$ & $6.60 \times 10^{-1}$ & $5 \times 10^{-8}$ \\
\hline $90_{S r}$ & $4.0 B \times 10^{4}$ & $7 \times 10^{-3}$ \\
\hline${ }^{99} \mathrm{Tc}$ & $1.41 \times 10^{2}$ & $1 \times 10^{-5}$ \\
\hline $932 \mathrm{rlb}$ & $6.96 \times 10^{1}$ & $6 \times 10^{-6}$ \\
\hline
\end{tabular}

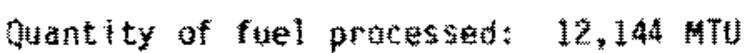

Note: Combined activities are listed for isotape pairs, no continatency is

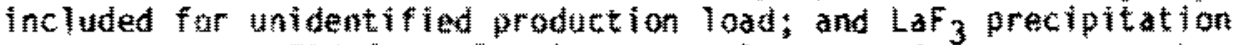

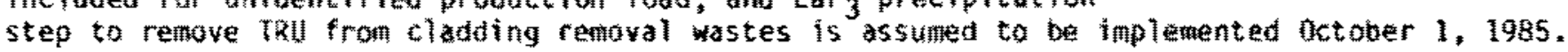

Activacion Products

\begin{tabular}{|c|c|c|}
\hline Radionuclide & c) & cilag \\
\hline $341_{\text {An }}$ & $3.76 \times 10^{3}$ & $3 \times 10^{3}$ \\
\hline $239 \mathrm{pu}$ & $2.69 \times 10$ & \\
\hline $240 \mathrm{P}_{\mathrm{U}}$ & $2.69 \times 10^{2}$ & $2 \times 10^{-5}$ \\
\hline $241 \mathrm{Pu}$ & $2.69 \times 10^{2}$ & \\
\hline $235 \mathrm{U}$ & $2.06 \times 10^{-1}$ & $2 \times 10^{-6}$ \\
\hline $238 \mathrm{y}$ & 4.03 & $3 \times 10^{-7}$ \\
\hline
\end{tabular}

$\frac{\text { addonuclide }}{\operatorname{la}^{6}}$

$\frac{\mathrm{c}(1 \mathrm{~kg}(\mathrm{~b})}{5 \times 10^{-6}}$

$60_{00} \quad 5.13 \times 10^{1} 5 \times 10^{-6}$

$55 \mathrm{Fe} \quad 4.90 \times 10^{4} 4 \times 10^{-3}$

$54 \mathrm{mu} \quad 6.89 \times 10^{2} 5 \times 10^{-5}$

$95 \mathrm{H}_{\mathrm{ND}} \quad 1.03 \times 10^{5} \mathrm{~g} \times 10^{-3}$

$59 \mathrm{Ni} \quad 2.08 \times 10^{1} 2 \times 10^{-6}$

$63_{\mathrm{Ni}} \quad 1.83 \times 10^{3} 2 \times 10^{-4}$

$125_{\text {sb }} \quad 6.00 \times 10^{4} 5 \times 10^{-3}$

$113 \mathrm{Sn} \quad 6.07 \times 10^{3} 5 \times 10^{-4}$

$119 \mathrm{~m} \mathrm{sin} \quad 1.16 \times 10^{5} \quad 1 \times 10^{-2}$

$12 \lim 5 n \quad 8.56 \times 10^{1} 7 \times 10^{-6}$

$932 r \quad 1.92 \times 10^{1} 2 \times 10^{-6}$

$952 r \quad 9.37 \times 10^{4} 8 \times 10^{-3}$

a) Ci listed in Rockwell (1985).

(t) Volume 800 \& $/ M T U_{\text {, }}$ sp ar 1.25 at $200^{\circ} \mathrm{C}$. 


\section{TABLE 9.4. Activity in Terninal "Product" Forms from New Tanked Waste Decayed to 1995}

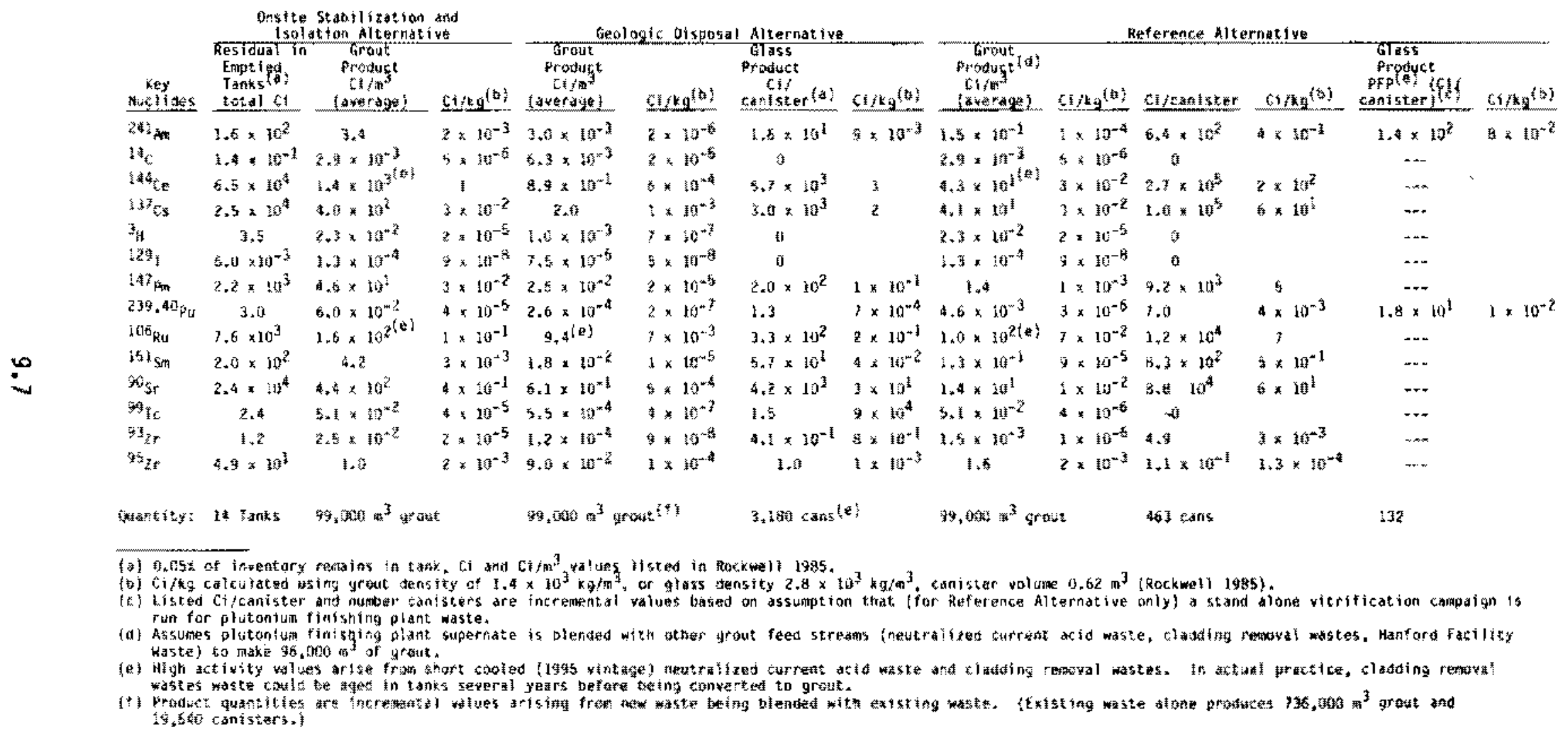




\subsection{CESIUM AND STRONTIUM CAPSULE INVENTORIES}

Cesium and strontium wastes are concentrated and encapsulated in relatively pure form along with their respective stable isotopes counterparts. The characteristics of the existing capsules are shown in Table 9.5 (Rockwell 1985, p. 7). To conservatively estimate the potential radiological impacts to the public from operational accidents during the proposed operations, the capsules containing the highest curie content are assumed to be involved in any postulated accident. The curie concentration was calculated assuming a $2.2 \times 10^{3} \mathrm{~g}$ waste mass per capsule as developed in Section 5.3.1.3. Details on the number of capsules assumed, heat loading, and the number of canisters anticipated for each of the alternatives are shown in Table 9.6 (Rockwell 1985). The values in Table 9.6 assume that all the cesium and strontium aqueous waste currently in 8-Plant will be processed and encapsulated.

\subsection{TRU-CONTAMINATED SOIL SITES - REFERENCE RADIONUCL IDE INVENTORIES}

Three upper-bound inventories are provided in order to cover the anticipated range of characteristics for TRU-contaminated soil sites. These inventories are an upper-bound TRU inventory site, an upper-bound fission product inventory site, and an upper-bound TRU concentration site. Data from characterized sites are presented to give a realistic estimate of the amount of radionuclides that could be encountered. Inventory data for more than one site are given because no single site exhibits the characteristics that makes it an upper-bound inventory site for all types of release scenarios.

\subsubsection{Upper-Bound TRU Inventory Site}

The site containing the highest inventory of TKU, 216-Z-1 + 2TF is chosen to represent the upper-bound TRU inventory site (Rockwell 1985). The inventory (Rockwell 1985) is shown in Table 9.7. The assumption and conversion factors shown in Rockwell (1985) apply to these data. Appropriate dimensions for the 216-Z-1+2TF site are 92-m long by 13-m wide for the area over TRU contaminated soil. The total estimated volume of TRU contaminated soil is $8,300 \mathrm{~m}^{3}$ with a density of $1.81 \mathrm{~g} / \mathrm{cm}^{3}(15,000 \mathrm{MT}$ of soil). 
IABLE 9.5. Characteristtes of Existing Strontiun and Cesium Capsules (as of December 1983)

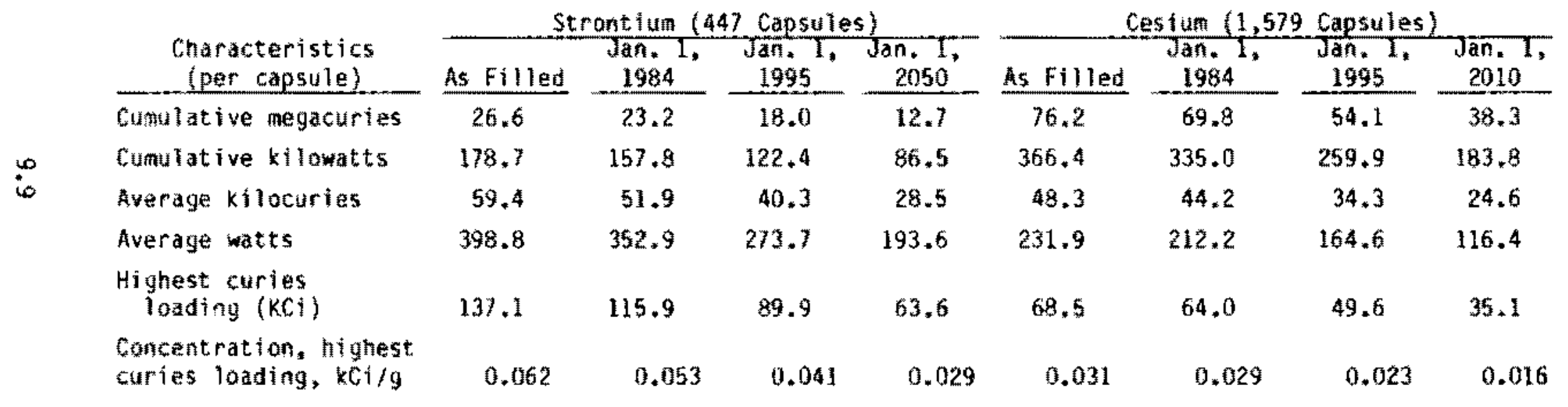


TABLE 9.6. Assumed Strontium and Cesium Capsule and Capsule Canister Details

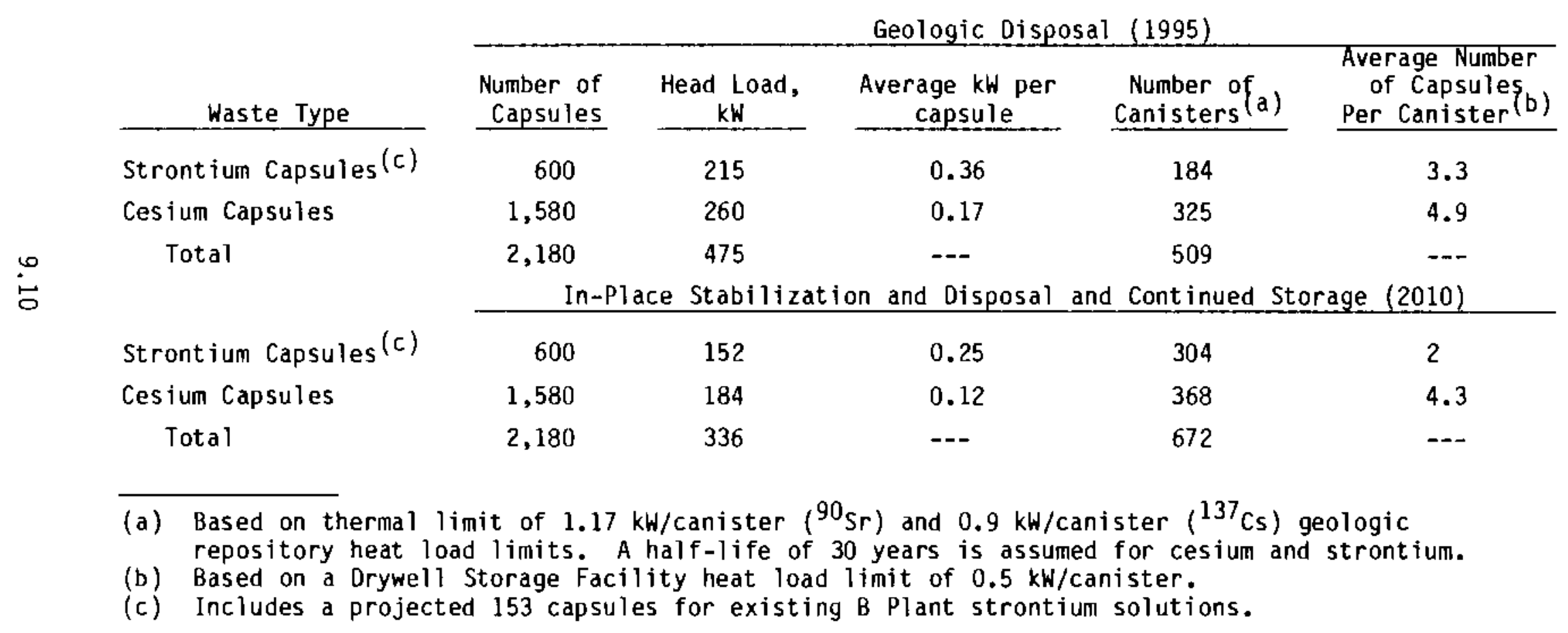


TABLE 9.7. Upper-Bound TRU and Fission Product Site Inventory Data (Through Decenter 1982) for TRU-Contaninated Soil Sites

\begin{tabular}{|c|c|c|c|c|c|}
\hline & Radionuclide & $\begin{array}{c}\text { Maximum } \\
\text { TRU Site, } \\
216-\mathrm{zm} 1+2 \mathrm{TF} \\
\mathrm{Ci} \\
\end{array}$ & $\begin{array}{c}\text { Maximuml }(a, b) \\
\text { TRU Concen- } \\
\text { tration, } \\
\text { Ci/kg } \\
\end{array}$ & $\begin{array}{c}\text { Maximum } \\
\text { Fission } \\
\text { Product } 54 \text { te } \\
216-5-1+2 \\
\text { Ci }\end{array}$ & $\begin{array}{l}\text { Maximum } \\
\text { Fission } \\
\text { Product Con- } \\
\text { centration, } \\
\mathrm{Ci} / \mathrm{kg} \\
\end{array}$ \\
\hline & $241 \mathrm{An}$ & $1.3 \times 10^{3}$ & $1 \times 10^{-4}$ & $2.5 \times 10^{1}$ & $9 \times 10^{-6}$ \\
\hline & $60 \mathrm{co}$ & $1.1 \times 10^{-1}$ & $7 \times 10^{-9}$ & $2.5 \times 10^{-1}$ & $8 \times 10^{-8}$ \\
\hline & $137 \mathrm{cs}$ & 1.2 & $8 \times 10^{-8}$ & $1.3 \times 10^{3}$ & $4 \times 10^{-4}$ \\
\hline & $23 \mathrm{~s}_{\mathrm{pu}}$ & $1.8 \times 10^{2}$ & $1 \times 10^{-5}$ & 3.3 & $5 \times 10^{-7}$ \\
\hline & $239 \mathrm{pu}$ & $3.7 \times 10^{3}$ & $3 \times 10^{-4}$ & $6.8 \times 10^{1}$ & $2 \times 10^{-5}$ \\
\hline & 240 & $9.1 \times 10^{2}$ & $6 \times 10^{-9}$ & $1.7 \times 10^{1}$ & $5 \times 10^{-6}$ \\
\hline & $241 p_{\mathrm{U}}$ & $2.5 \times 10^{3}$ & $9 \times 10^{-4}$ & $4.7 \times 10^{1}$ & $6 \times 10^{-5}$ \\
\hline & $242 \mathrm{pu}$ & $5.3 \times 10^{-2}$ & $3 \times 10^{-9}$ & $9.9 \times 10^{-4}$ & $2 \times 10^{-9}$ \\
\hline & $106_{8 \mathrm{U}}$ & $1.1 \times 10^{-2}$ & $7 \times 10^{-10}$ & $1.3 \times 10^{-5}$ & $4 \times 10^{-12}$ \\
\hline & $90_{5 r}$ & 1.2 & $8 \times 10^{-8}$ & $1.5 \times 10^{3}$ & $5 \times 10^{-4}$ \\
\hline & $233 \mathrm{~J}$ & $3.6 \times 10^{-2}$ & $2 \times 10^{-9}$ & 1.0 & $3 \times 10^{-7}$ \\
\hline & $234 \mathrm{U}$ & $3.7 \times 10-^{2}$ & $2 \times 10^{-9}$ & 1.0 & $3 \times 10^{-7}$ \\
\hline & $235 \mathrm{U}$ & $1.1 \times 10^{-3}$ & $7 \times 10^{-11}$ & $3.1 \times 10^{-2}$ & $1 \times 10^{-8}$ \\
\hline & $238 \mathrm{U}$ & $2.7 \times 10^{-2}$ & $2 \times 10^{-9}$ & $7.6 \times 10^{-1}$ & $2 \times 10^{-7}$ \\
\hline Total & Beta & $2.5 \times 10^{3}$ & & $5.7 \times 10^{3}$ & \\
\hline Iotai & Uraniun (grams) & $8.1 \times 10^{4}$ & & $2.3 \times 10^{6}$ & \\
\hline Total & Plutontum (grams) & $6.4 \times 10^{4}$ & & $1.2 \times 10^{3}$ & \\
\hline
\end{tabular}

(a) Based on $8,300 \mathrm{~m}^{3}$ in site $216-2-1+2$ TF and bulk density of Hanford $50115 \div 1.83$.

(b) Peak TeU concentrations 40,000 ncilg wo tines higher than average shown in column.

\section{4 .2 Upper*Bound Fisston Product Site}

A liquid-TRU-contaminated soil site containing the highest total quantity of fission product activity was selected as the representative site for this class of material. This allows consideration of the impact of release scenarios depending primarily on beta-gamma emissions. The inventory data for the site chosen, 216-5-1.2, are shown in Table 9.7 . This site volume is $1700 \mathrm{~m}^{3}$ 
(Rockwell 1985) or about 3100 MT of soil. The upper-bound site inventory (Rockwell 1985) is used to estimate the potential radiological impacts to the public from accidents postulated to occur during disposal operations for this class of sites.

\subsubsection{Upper-Bound TRU Concentration}

The upper-bound TRU concentration that might be encountered within a localized area is of concern for some release scenarios. Characterization data (Price et al. 1979) have reported TRU concentrations up to $40,000 \mathrm{nCi} / \mathrm{g}$ in small volumes. This value is roughly 200 times the average concentration for the upper-bound TRU site. This concentration is projected to occur within only the first $1 / 3-m$ depth from the source of contamination with the TRU concentration decreasing to less than $1000 \mathrm{nCi} / \mathrm{g}$ at a distance of $2 \mathrm{~m}$ to less than $100 \mathrm{nCi} / \mathrm{g}$ at $15 \mathrm{~m}$.

9.5 PRE-1970 TRU SOLID WASTE BURIAL GROUND - REFERENCE RADIONUCLIDE INVENTORY

Three classes of inaterial are described for this category of waste: an upper-bound TRU inventory site; an upper-bound fission product inventory site; and, an upper-bound TRU concentration site. Measured values from actual sites are used to give a realistic upper-bound estimate of the amounts of radionuclides that could be encountered. Inventory data for inore than one site are given because no single site exhibits the characteristics that make it an upper-bound inventory site for all types of release scenarios.

\subsubsection{Upper-Bound TRU Inventory Site}

Inventory data for the $218-W-2$ site, the site containing the largest total inventory of TRU, is shown in Table 9.8 and was taken from Rockwell (1985). Assumptions and conversion factors for determining isotopic ratios of uranium and plutonium in that document were applied to these data to estimate the appropriate radionuclide inventory. The approximate dimensions of the site are $124 \mathrm{~m}$-long by $179 \mathrm{~m}$-wide for the area over the TRU waste, with a total volume is listed in the Rockwell document and estinated at $23,000 \mathrm{~m}^{3}\left(4 \times 10^{10} \mathrm{~g}\right)$. 
TABLE 9.8. Upper-Bound TRU Inventory Site $(218-\mathrm{W}-2)$ for Pre-1970 Solla waste gurial Grounds

\begin{tabular}{|c|c|}
\hline Radionuclide & Inventory, $\mathrm{Ci}$ \\
\hline $241_{A m}$ & $2.6 \times 10^{3}$ \\
\hline${ }^{137} \mathrm{Cs}$ & 5.6 \\
\hline${ }^{238} \mathrm{Pu}$ & $3.4 \times 10^{2}$ \\
\hline $239_{\mathrm{pu}}$ & $7.2 \times 10^{3}$ \\
\hline $240 \mathrm{pu}$ & $1.8 \times 10^{3}$ \\
\hline $241_{\mathrm{Pu}}$ & $5.0 \times 10^{-3}$ \\
\hline $242_{u}$ & $1.0 \times 10^{-1}$ \\
\hline $90_{S r}$ & 5.0 \\
\hline $233 v$ & $6.2 \times 10^{-1}$ \\
\hline $234 v$ & $6.4 \times 10^{-1}$ \\
\hline $235_{\mathrm{U}}$ & $1.9 \times 10^{-2}$ \\
\hline $238_{\mathrm{U}}$ & $4,7 \times 10^{-1}$ \\
\hline Total Beta & $5.0 \times 10^{3}$ \\
\hline Total U (grams) & $1.4 \times 10^{6}$ \\
\hline Total Pu (grams) & $1.3 \times 10^{5}$ \\
\hline volume, $m^{3}$ & $2.3 \times 10^{4}$ \\
\hline Area, $n^{2}$ & $1.5 \times 10^{4}$ \\
\hline $\begin{array}{l}\text { Hanford soil } \\
\text { density, } \mathrm{g} / \mathrm{cm}^{3}\end{array}$ & 1.8 \\
\hline
\end{tabular}

\subsubsection{Upper-Bound Fisston Product Inventory site}

nthough not defined as a TRU waste site, the $218-E-128$ site containing the highest total fission product activity was selected to allow consideration of release scenarios depending prinarily on betamama emissions. The inventory data (Rockwel) 1985) for the site are given in Table 9.9. Concentrations were calculated based on a $4400 \mathrm{~m}^{3}$ (Rockwell 1985) waste volume.

\subsubsection{Upper-Bound TRU Concentration Site Inventory}

The upper-bound TRU concentration anticipated in a localized area during the proposed disposal operations for this class of materials is of concern for some release stenarios. Caissons have the tighest concentrations of TRU found 
TABLE 9.9. Upper-Bound Fission Product (not a TRU Site) Inventory Site (218-E-12B) for Pre-1970 TRU Solid Waste Burial Ground

\begin{tabular}{|c|c|c|}
\hline Radionuclide & Inventory, $\mathrm{Ci}$ & $\begin{array}{c}\text { Concentration, } \\
\mathrm{nCi} / \mathrm{g}\end{array}$ \\
\hline $241_{\text {A }}$ & $2.4 \times 10^{1}$ & 3 \\
\hline${ }^{60} \mathrm{Co}_{\mathrm{O}}$ & $6.6 \times 10^{4}$ & $8 \times 10^{3}$ \\
\hline${ }^{137} \mathrm{Cs}$ & $2.6 \times 10^{4}$ & $3 \times 10^{3}$ \\
\hline $238 \mathrm{Pu}$ & 3.2 & $6 \times 10^{-1}$ \\
\hline${ }^{239} \mathrm{Pu}$ & $6.6 \times 10^{1}$ & 8 \\
\hline $240 \mathrm{Pu}$ & $1.6 \times 10^{1}$ & 2 \\
\hline $241_{\mathrm{Pu}}$ & $4.6 \times 10^{1}$ & 6.9 \\
\hline${ }^{242} \mathrm{pu}$ & $9.5 \times 10^{-4}$ & $1 \times 10^{-4}$ \\
\hline $106_{\mathrm{Ru}}$ & $1.3 \times 10^{1}$ & $1.6 \times 10^{1}$ \\
\hline${ }^{90} \mathrm{Sr}$ & $2.6 \times 10^{4}$ & $3 \times 10^{3}$ \\
\hline $233 \mathrm{U}$ & $1.3 \times 10^{-2}$ & $2 \times 10^{-3}$ \\
\hline $234 U$ & $1.3 \times 10^{-2}$ & $2 \times 10^{-3}$ \\
\hline $235_{U}$ & $3.9 \times 10^{-4}$ & $5 \times 10^{-5}$ \\
\hline $238_{\mathrm{U}}$ & $9.5 \times 10^{-3}$ & $1 \times 10^{-3}$ \\
\hline Total Beta & $1.4 \times 10^{5}$ & \\
\hline Total U (grams) & $2.9 \times 10^{4}$ & \\
\hline Total Pu (grams) & $1.2 \times 10^{3}$ & \\
\hline Vol ume, $\mathrm{m}^{3}$ & $4.4 \times 10^{3}$ & \\
\hline Area, $m^{2}$ & $3.4 \times 10^{3}$ & \\
\hline $\begin{array}{l}\text { Hanford soil } \\
\text { density, } \mathrm{g} / \mathrm{cm}^{3}\end{array}$ & 1.8 & \\
\hline
\end{tabular}

in this class of waste. The inventory for the $218-W-4 B$ cajssons has an average concentration of $6,200 \mathrm{nCi} / \mathrm{g}$. This concentration would be projected to occur within a caisson $3 \mathrm{~m}$ deep $\times 2 \mathrm{~m}$ in dianeter under overburden that is $4.5 \mathrm{~m}$ deep. Inventories and concentrations to be used for this estimate of the potential radiological impacts from operational accident where upper-bound concentrations are used are shown in Table 9.10. 
TABLE 9.10. Upper-gound TRU Concentration Inventory site $(218-W-4 B)$

for Prem1970 TRu Solld Waste Burtal Grounds

\begin{tabular}{|c|c|c|}
\hline Radionuclide & Inventory, ci & $\begin{array}{c}\text { Concentration, ( ) } \\
\text { nCi/g }\end{array}$ \\
\hline $233 \mathrm{u}$ & $1.3 \times 10^{\mathrm{m} 1}$ & 1.5 \\
\hline $234 \mathrm{U}$ & $1.4 \times 10^{-1}$ & 1.5 \\
\hline 235 & $4.2 \times 10^{-3}$ & $4.6 \times 10^{-2}$ \\
\hline $238 \mathrm{u}$ & $1.0 \times 10^{-1}$ & 1.1 \\
\hline $238 \mathrm{p}_{\mathrm{u}}$ & 4.5 & $5.0 \times 10^{1}$ \\
\hline $239 \mathrm{Pu}$ & $9.5 \times 10^{1}$ & $1.1 \times 10^{3}$ \\
\hline $240 \mathrm{pu}$ & $2.3 \times 10^{1}$ & $2.6 \times 10^{2}$ \\
\hline $241_{p_{u}}$ & $6.6 \times 10^{1}$ & $7.3 \times 10^{2}$ \\
\hline${ }^{24} 2_{p} u$ & $1.4 \times 10^{-3}$ & $1.5 \times 10^{-2}$ \\
\hline $241 \mathrm{Am}$ & $3.5 \times 10^{1}$ & $3.8 \times 10^{2}$ \\
\hline $237 \mathrm{kp}$ & 0.0 & 0.0 \\
\hline $232 \mathrm{Th}$ & $7.4 \times 10^{-3}$ & $8.2 \times 10^{-2}$ \\
\hline $106_{\mathrm{Pu}}$ & $1.7 \times 10^{1}$ & $1.9 \times 10^{2}$ \\
\hline $90 \mathrm{Sr}$ & $2.0 \times 10^{3}$ & $2.2 \times 10^{4}$ \\
\hline $137 \mathrm{Cs}$ & $1.8 \times 110^{3}$ & $2.0 \times 10^{4}$ \\
\hline${ }^{60} \mathrm{Co}$ & $5.3 \times 10^{2}$ & $5.9 \times 10^{3}$ \\
\hline $144 \mathrm{ce}$ & 1.8 & $2.0 \times 10^{1}$ \\
\hline $144 \mathrm{pr}$ & 1.8 & $2.0 \times 10^{1}$ \\
\hline Total Beta & $8.6 \times 10^{3}$ & $9.6 \times 10^{4}$ \\
\hline Total $\cup$ (grams) & $3.0 \times 10^{5}$ & \\
\hline Total Pu (grams) & $1.7 \times 10^{3}$ & \\
\hline Volume, $\mathrm{m}^{3}$ & 50 & \\
\hline
\end{tabular}

(a) Note: Orly parent radionuclide activities for $90 \mathrm{Sr}$. $30 y, 137 \mathrm{Cs}+137 \mathrm{mBa}$, and $10 \mathrm{f}_{\mathrm{Ru}}-10 \mathrm{C}_{\mathrm{Rn}}$ pairs are 1isted. Total beta, however includes daughters, and is the sum of specifically identified fission product isotopes, plus reported general activity (without spectfic isotopes given). In most cases, the general activity can be treated as approximately $50 \%$ each strontium and cesium activity. 
Inventory values are as of December 31,1982 , except plutonium and americium alpha-emitting isotope values are decayed to maximum $24 l_{\text {Am buildup. }}$

\subsection{RETRIEVABLE STORED AND NEWLY GENERATED TRU SOLID WASTE -} REFERENCE RADIONUCLIDE INVENTORIES

Three sites were selected as upper-bound inventory sites based on the descriptions and inventories of the retrievably stored TRU solid waste sites (Rockwell 1985). The sites are designated as the primary, secondary, and tertiary sites. The primary site was selected on the basis of the site that contained the highest TRU inventory without regard to fission product or TRU concentrations. The secondary site was selected on the basis of the highest total fission product inventory. The tertiary site was selected on the basis of the highest peak TRU concentrations radionuclide inventories and concentrations are listed in Table 9.11. Waste densities are included in the table, with contact handled TRU density $0.32 \mathrm{~g} / \mathrm{cm}^{3}$, caissons at $0.96 \mathrm{~g} / \mathrm{cm}^{3}$.

\subsubsection{Primary Site}

The primary site (the highest TRU inventory site) selected was the 218-W-4C burial ground; the inventories (Rockwell 1985) are listed in Table 9.11. The total TRU inventory is $5.20 \times 10^{4} \mathrm{Ci}$ and contains retrievably stored TRU in trenches. If the isotopic values can be assumed to be average values and the peak to average concentration ratio is 10 to 1 , then the peak concentration can be obtained by dividing by the volume, $4.90 \times 10^{3} \mathrm{~m}^{3}$, and density $0.32 \mathrm{~g} / \mathrm{cm}^{3}$ and multiplying by a factor of 10 . This peak concentration should bound most of the retrievable TRU waste sites.

The following secondary and tertiary sites can be added to modify the characteristics of the primary site to develop additional upper-bound sites as required.

\subsubsection{Secondary Site}

The secondary site selected and listed in Table 9.11 was the 218-W-3A burial ground since it had the highest fission product inventory (Rockwell 1985). It is not defined as a TRU waste site. The primary radionuclides considered in this selection were ${ }^{137} \mathrm{Cs}$ and ${ }^{90} \mathrm{~S} r$. The fission product 
TABLE 9.11. Retrievably Stored TRU (1970-FY-1983) Inventory (a)

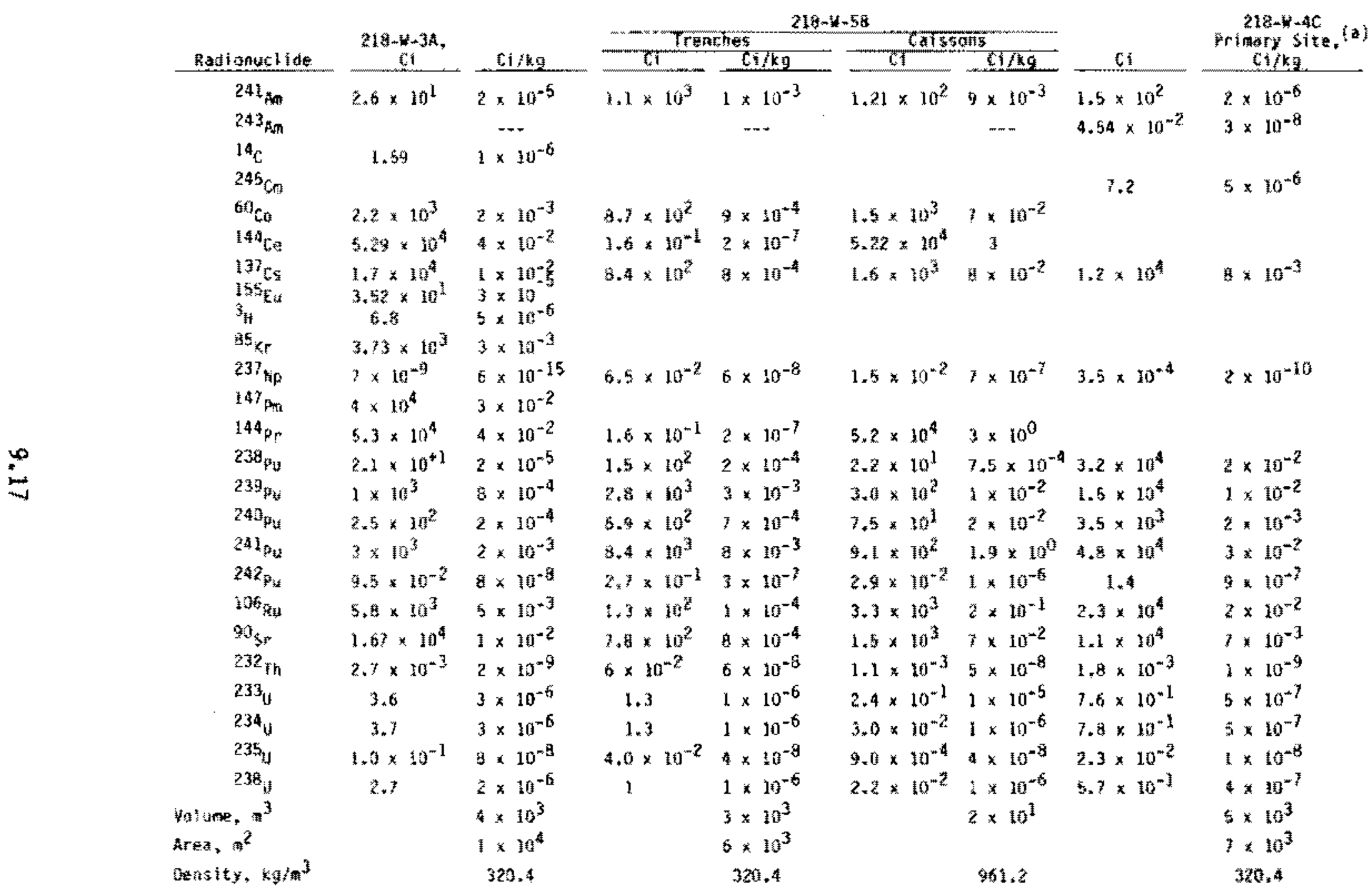

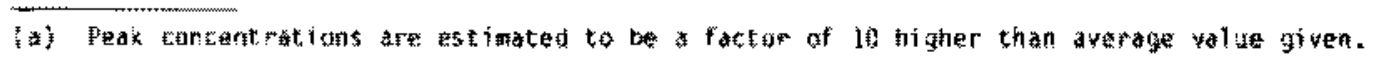


inventory is: ${ }^{90} \mathrm{Sr}, 1.67 \times 10^{4} \mathrm{Ci}$, and ${ }^{137} \mathrm{Cs}, 1.70 \times 10^{4} \mathrm{Ci}$. The peak anticipated concentration can be obtained by dividing the volume of $3.9 \times$ $10^{3} \mathrm{~m}^{3}$ and the density and multiplying by a factor of 10 .

\subsubsection{Tertiary Site}

The tertiary site selected on the basis of having the highest TRU concentration was 218- $H-4 B$, and included caisson waste. A total of $21.7 \mathrm{~m}^{3}$ (Rockwell 1985) of caisson waste was received from 1970 through FY 1983. Radionuclide inventories (Rockwell 1985) and concentrations for the 218-W-48 site are included in Table 9.11. Newly generated caisson waste can have stightly elevated levels of certain important radionuclides (Rockwell 1985). Because of the very small volume of waste involved, this site is not considered representative of the majority of waste within this category. 


\subsection{DOWNWIND TRANSPORT DOSE CALCULATIONAL METHODS \\ ANO RAOIATION DOSES FROM POSTULATED \\ OPERAT IONAL ACCIOENTS}

Population and maximum-individual dose estimates were calculated for each accident scenario postulated for a waste processing activity. Occupational doses for these accident \$ituations were not addressed because of the unavailabllity of facllity specifle information fsuch as manpower requirements, shieldIng, distance from the source, etc.) essential to the analysis of occupatonal dose. The assumptions, models, and input parameters required for the calculation of maximum individual and population dose estimates for each of the waste disposal, along with the dose alternatives, are described below.

\subsection{ACCDDENT SCENARIOS}

Many different accident scenarios were developed as part of this project. only those accidents which resulted in an arborne release of radioactive material to the offsite environment were considered in the dose analysis. Releases of radioactive material to the air and in liquid discharges were postulated, but only atmospheric accidental releases had the potential for inigrating of site during waste disposal actuities.

The duration of a release during an accident can have a significant bearing on the radiological consequences of the event. In this study all releases were postulated to be of short duration (less than an hour). Even with a short, -term, or acute, release there are many ways in which the radionuclides can continue to expose the population long after the release has been terininated. For example, in a typical accident scenaria, a cloud (or plume) of contaminated material is postulated to be released. As this plume travels offstak, members of the public may be irradiated by the radionuclides contained in the cloud passing overhad. If they inhale some of the radioatche material fron the cloud as it passes they can recelve an additional exposure. If some of the radioactive material deposits on plants or on the ground it can result in long-tern exposure to people residing in the ared. While the posstbilities for exposure seem large and complex, a set of computer programs has been 
developed to calculate the dose consequences from all the major exposure pathways from each of the bastc release scenarios, These programs, listed in Table 10.1, are discussed in the following section. All have been individually documented.

\subsection{DOSE COOES}

Several computer programs, or dose codes, were used to calculate the radiation dose to members of the public in the event of an accidental release of radioactive material to the environment. The standard method for evaluating the radiological impact of a release is to estimate the dose to the "maximallyexposed "individual" (the single person receiving the highest dose fram the release) and to the entire exposed population as whole. The doses are reported in reci for the maximum individual and manwen for the population.

The computer prograns used to calculate dose to the maximally-exposed individual and to the regional population are shown in Figure 10.1. The prom grams SUBO0SA (Strenge, Hatson and Houston 1975), DACRLN (Houston, Strenge and

TABLE 10.1. Computer Prograns Used to Calculate Potential Radiation Doses from Releases During waste bisposal Dperations

\begin{tabular}{|c|c|}
\hline Program & Type of Dose \\
\hline SUBDOSA & $\begin{array}{l}\text { One-year air submersion dose from acute (finite } \\
\text { cloud) or chronic (semi-infinite cloud) releases }\end{array}$ \\
\hline DACRIN & $\begin{array}{l}\text { Individual and collective inhalation doses from } \\
\text { chronic or acute releases, one-year doses, dose } \\
\text { commitments, and accumulated doses. }\end{array}$ \\
\hline
\end{tabular}

PABLM Individual and collective doses fron contaminated farn products, fron either air deposition or irrigation, one-year tose, dose commitment, and accumulated dose. Individual and collective doses from contaminated water and aquatic foods and aquatic recreation, one-year dose, dose comitiment, and accumulated dose.

ALLDOS Report generator using precalculated factors from SURLOSA, DRCRI ll and PABLM. Simplifies repetitive calculations of individual and population doses.
Reference

Strenge, Watson and Houston 1975

Houston, Strenge and Watson 1974; Strenge et al. 1975

Napjer, Kennedy and soldat 1980

Strenge et al. 1990 


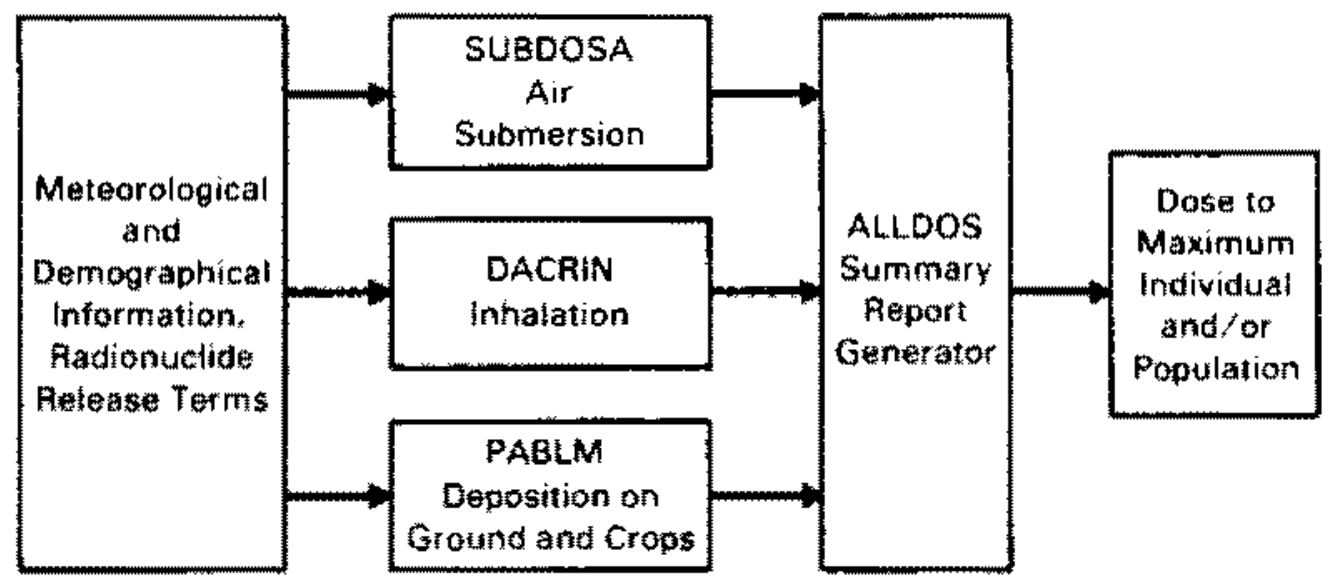

Fule 10.1. Computer Frograns for Calculating Public Doses from Routine or Aceidental Releases of Radionuclides During Dperations

Watson 1974, Strenge et al. 1975), and PABLM (Napter, Kennedy and Soldat 1980) uses information about the radionuclides released, meteorology, and population distribution to calculate air submersion, inhalation, and ingestion doses, respectively. For cases in which repetitive calculations are necessary for the same environmental conditions (as for the various alternatives at hanford), it was convenient to use a fourth program, ALLDOS (Strenge et al, 1980), to summarize the results of the calculations. This combination of computer programs was used for the acute accldental releases postulated for operations involving the hanford wastes.

ALLos uses precalculated dose conversion factors to generate dose comitments to a naximum individual and the population in the reglon of the release site. The code was developed for calculation of radiation doses from postulated releases of aged radloactlve wastes. These radlonuclides are long-lived with decay half-lives of several weeks or longer. Therefore, radioactive decay in transit from the release point to the location of expasure in the environment is not considered.

\subsection{STANOARD HANFORO METEOROLOGICAL PARAMETERS}

The dose calculations rely on the use of meteorological data to provide an estimate of the manner in wich radioactive material would most likely disperse 
following an accidental release to the atmosphere. The longer the data have been collected, the more redistic the estimate. Meteorological data have been collected at the Hanford Meteorology Station, near 200 West Area, for the past 30 years (Stone et al. 1983). The results of these monitoring efforts are published in Hanford Annual Reports (Sula et al. 1982,1983).

For short-term accidental releases, the meteorological parameter used in the dose calculations is the value of air concentration of radionuclides per unit release that is not exceeded more than $5 \%$ of the time; it is referred to as $\mathrm{E} / \mathrm{Q}$, with units of $\mathrm{sec} / \mathrm{m}^{3}$. Typically the results of the metaorological efforts are tabulated and reported as $X / Q^{\prime}$, or $c i / \mathrm{m}^{3}$ per $\mathrm{Ci} / \mathrm{sec}$ of release. The value of $X / Q^{\prime}$ can be converted to $E / Q$ when the length of release is known or can be estimated. Values of ${ }^{\prime} / Q^{*}$ used in these calculations were based on data given in PN-3777 Rev I (McCormack, Ramsdell, and Napier, 1984).

Demographical data also play an important role in the calculation of radiation dose. It is the combination of meteorological and demographical information that indicate wich population group will receive the highest exposure from radioactive releases. In the case of accidental releases from the 200 Areas of the hanford site, the population projected to receive the greatest exposure lives 10 to 50 miles SE of the waste site. The population data used in this assessment came from Population Estimates for the Areas Whin a 50-Mile Radius of Four Reference Points on the Hanford 31 te 1 somer, Rau, Robinson, 1981). Meteorological and population data used in the dose cal. culations are shown in Table 10.2.

For the maximally-exposed individual, the $95 \mathrm{t}$ (n Percentile center-1ine $x / Q^{\prime}$ values provided in Hanford Dose Overview Program: Standardized Methods and Data for Wanford Enviromental Dose Calgulations were used (McCormack, Ramsdell, and hapier 1984), The following assumptions were used to determine the location of the maxinally exposed individual for accidental releases. For purposes of inhalation and submersion dose calculations, the maximally exposed individual was assumed to be positioned on Highway $240,8.8 \mathrm{~km}$ south of the 200 Areas; but for ingestion dose calculations this person is presumed to live 
TABLE 10.2. Population Values and Sector Averaged $x / Q^{\prime}$ s used in the Assessment of Radiation Dose

\begin{tabular}{|c|c|c|c|}
\hline $\begin{array}{c}\text { oistance, } \\
\text { fijles }\end{array}$ & $\begin{array}{c}\text { Population } \\
\text { Size }\end{array}$ & $\begin{array}{c}\text { Ground Level } \\
\times / 0^{:}\end{array}$ & $\begin{array}{c}\text { Elevated } \\
\quad x / 0^{7} \\
\end{array}$ \\
\hline $0-10$ & 0 & & \\
\hline $10-20$ & 8,664 & $1.02 \times 10^{-6}$ & $4.21 \times 10^{-7}$ \\
\hline $20-30$ & 62,866 & $5.76 \times 10^{-7}$ & $2.04 \times 10^{-7}$ \\
\hline $30-40$ & 66,306 & $4.10 \times 10^{-7}$ & $1.33 \times 10^{-7}$ \\
\hline $40-50$ & 4,094 & $3.10 \times 10^{-7}$ & $1.03 \times 10^{-7}$ \\
\hline $\begin{array}{l}\text { Populati } \\
x / p^{\prime}\end{array}$ & leighted & $7.35 \times 10^{-2}$ & $2.57 \times 10^{-1}$ \\
\hline
\end{tabular}

on a farm in Franklin County $24 \mathrm{~km}$ East of the 200 Areas. The values used in the calculations are shown in Table 10,3 .

\subsection{STANOARD HANFORD EXPOSURE PARAMETERS}

Data required for the dose programs include detary and recreational preferences and habits in the general population, as well as agricultural practices in the general region. The standard Manford terrestrial pathway data are given in sula and blumer (1981). The growing period, yield, and irrigation rate reflect agricultural practices in the Columbia River Basin. The parame* ters for the average nember of the population reflect the dietary habits of the Tri-cities residents. Values used for the maximally exposed individual were selected to represent a worst-case individul supporting himself and family with a large garden and farm animals. Standardized input for Hanford environmental documentation is sumarized in recent publications (hapier 1981 , McComack, Ramsdell and Napier 1984$).$

TABLE 10.3. Maximum Individual, 95th Percentlle Centerline $\mathrm{X}_{\mathrm{O}}{ }^{\prime}$ Values

\begin{tabular}{|c|c|c|c|}
\hline \multirow[b]{2}{*}{ Pathway } & \multirow[b]{2}{*}{ Location } & \multicolumn{2}{|c|}{ Elevation } \\
\hline & & Ground & 50 Meters \\
\hline Inha & $5 \mathrm{mi}$ & $3.40 \times 10^{-5}$ & $1.05 \times 10^{-5}$ \\
\hline Ingestion & $12 m i-E$ & $1.50 \times 10^{-5}$ & $4.90 \times 10^{-6}$ \\
\hline
\end{tabular}




\subsection{RADIATION DOSE ESTIMATES FROM ACCIDENTAL ATMOSPHERIC RELEASES DURING}

\section{WASTE DISPOSAL OPERATIONS}

Doses to the maximally-exposed individual and to the population living downwind from the Hanford Site were estimated for each of the proposed waste disposal alternatives. The atmospheric releases used as the basis for the dose calculations are those given for each of the accident scenarios listed in Tables $5.1,6.1,7.2$, and 8.1 and discussed in Sections $5,6,7$, and 8 .

\subsubsection{Radiation Doses Associated with the Geologic Disposal Alternative}

Twenty-six separate dose calculations were performed to analyze the potential radiological impact from the disposal of the Hanford Defense Wastes under the geologic disposal alternative. The dose estimates, listed in Tables lu.4a, $b$, and $c$, are divided according to the maximally exposed individual inhalation dose, the maximally exposed individual ingestion dose, and the population dose. For each of these three categories, the first year total body and critical oryan dose(a) and the 70 year total-body and critical-organ dose commitments were calculated. The accident resulting in the greatest public dose was the ferro/ferricyanide explosion postulated for the handling of the single-shell tank wastes. It has been postulated that a layer containing ferro- or ferricyanide precipitates might be present in the single-shell tank wastes. Under the proper conditions, this material could react explosively with nitrates present in the waste. If ferrocyanide precipitates are present in the waste, the potential for an explosion, as discussed in Sections 5, 6, and 7, does exist. However, the presence of such material, in quantities sufficient to produce such an event is still a subject of some debate (RHO-LD-55, Rockwell 1980).

The accident with the second-highest radiological consequences is from the pressurized release of liquid waste due to failure of a diversion valve during hydraulic retrieval of the tank wastes. This accident is described for both the existing and future tank wastes.

(a) The "critical organ" is the organ receiving the highest dose during the time period under consideration. 
TABLE 10.4a. Geologic Disposal Alternative Potential Doses from Accidental Releases for operations Involving Six waste forms (Max. Ind. Inhalation)

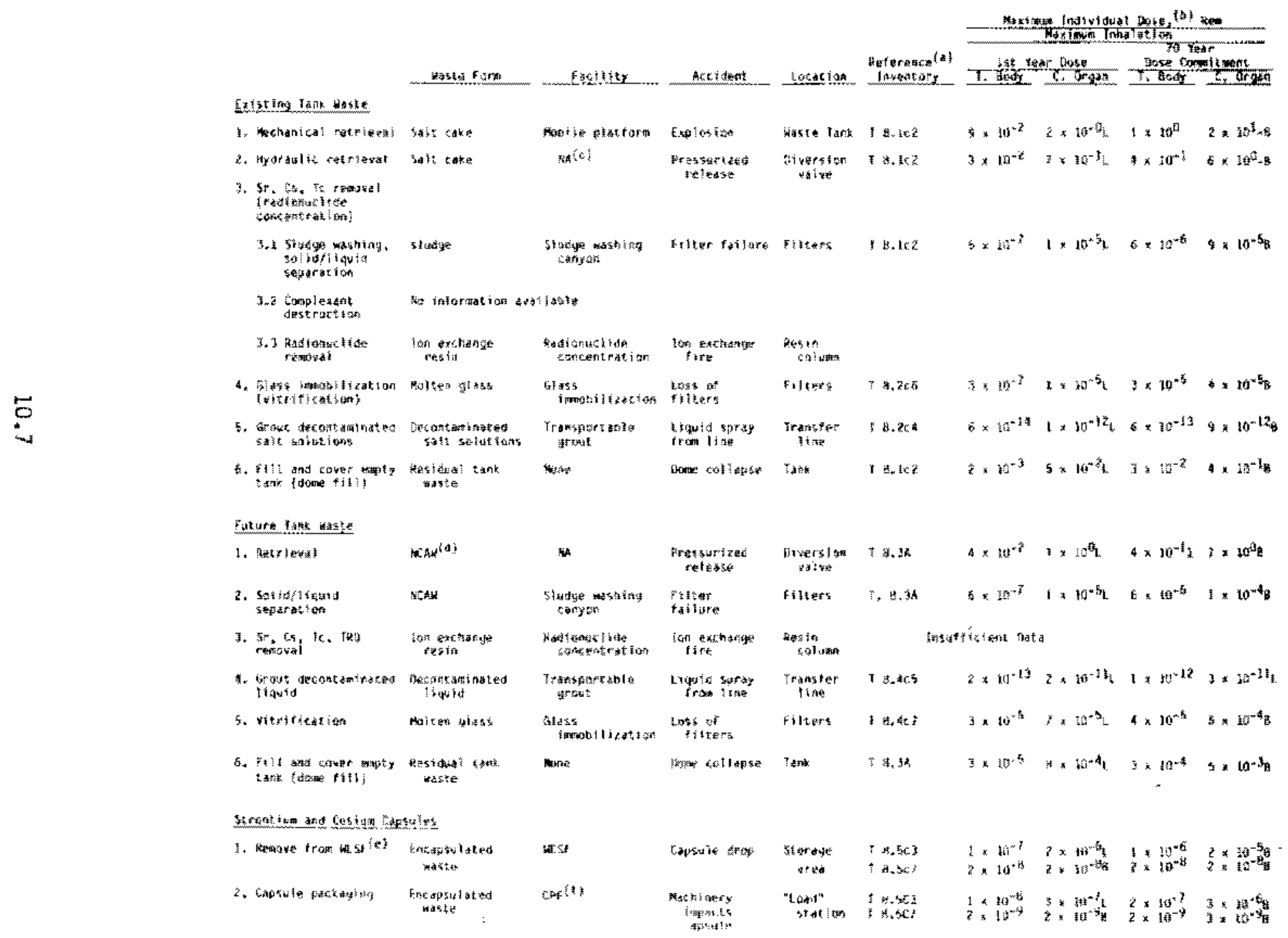




\section{TABLE 10.4a. (contd)}

\begin{tabular}{|c|c|c|c|c|c|c|c|c|c|}
\hline & \multirow[b]{2}{*}{ 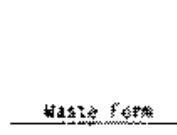 } & \multirow[b]{2}{*}{ 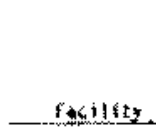 } & \multirow[b]{2}{*}{ 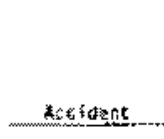 } & \multirow[b]{2}{*}{ tescistos } & \multirow[b]{2}{*}{ 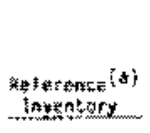 } & \multicolumn{4}{|c|}{ 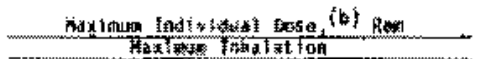 } \\
\hline & & & & & & 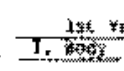 & 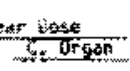 & 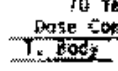 & 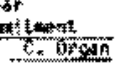 \\
\hline \multicolumn{10}{|l|}{ 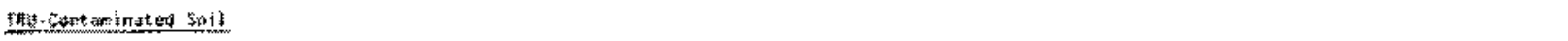 } \\
\hline 1. Eetrteve & 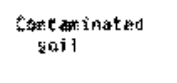 & $\begin{array}{l}\text { Aetraxys } \\
\text { Fentity }\end{array}$ & Explastitat & 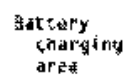 & $\mid \bar{z}, \overline{\mathrm{T}} \epsilon \bar{z}$ & $\neq \times 30^{-2}$ & $5 \times 30^{-x_{3}}$ & 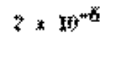 & $4 \times 2 n^{-x_{3}}$ \\
\hline 2. Procestat & 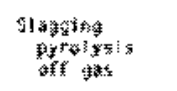 & $s p !(s)$ & 表然olasion & Gasioter & $5.3 \mathrm{c} z$ & $4 \times 30^{* 4}$ & $s x ! \theta^{+3}$ & $\pm \times\left. 1\right|^{2}$ & in $1 \mathrm{f}^{-4} \mathrm{~A}$ \\
\hline \multicolumn{10}{|l|}{ 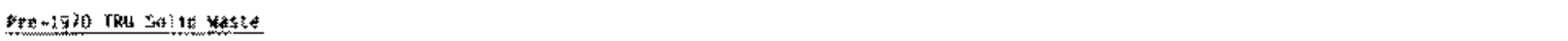 } \\
\hline 1. Hettiever & 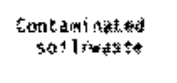 & $\begin{array}{l}\text { Petsingal } \\
\text { facility }\end{array}$ & 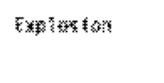 & 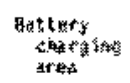 & 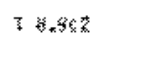 & $4 \times \mathrm{m}^{43}$ & $:=10^{-5}$ & $4 \times 10^{-3}$ & $x \times \mathbf{s i n}^{* *_{0}}$ \\
\hline 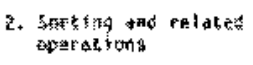 & 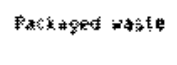 & sp! & $\begin{array}{l}\text { Frespurized } \\
\text { releasiet }\end{array}$ & Drua & 18,42 & $1 * z^{-1 / 2}$ & $4 \times 1 a^{-5 i_{1}}$ & $1 \div 200^{w}$ & $2 * 10^{*}: n_{\mathrm{E}}$ \\
\hline 7. Protes:5 & $\begin{array}{l}\text { Stagaing } \\
\text { Prolys is } \\
\text { offe }\end{array}$ & $\neq \neq$ & Extoustata & Ensifier & 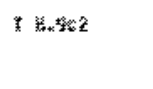 & $4 \times 10^{-5}$ & $8 \times \ln ^{4+\frac{4}{3}}$ & $1 \times 10^{n+5}$ & $2: \hat{y}^{-3}$ \\
\hline \multicolumn{10}{|c|}{ 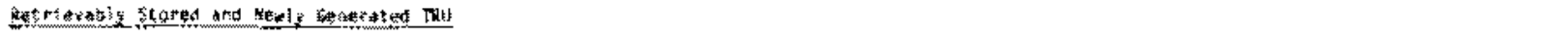 } \\
\hline E. & Backgçet wate & 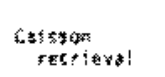 & 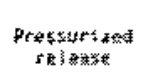 & Way & Y E, & $E \times 10^{-12}$ & $\therefore: 10^{2}+\mathrm{e}_{8}$ & $\neq * 10^{-x 0}$ & $3 \times 10^{\mu 18}$ \\
\hline 1.2. wh the & Prokayed waste & N:te & 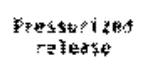 & Ory:a & I & $1 \neq \mathrm{in}^{-3}$ & $z x x^{*} t_{t}$ & $5 \times 1 \mathrm{w}^{* / 2}$ & $1 \times 1 \theta_{0}$ \\
\hline 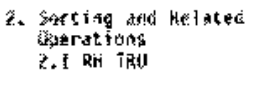 & Gackland waste & $\$$ & 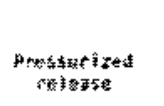 & Eevit & I & $3 \times 50^{-10}$ & $3 * \operatorname{lon}^{\circ}$ & a $\times 10^{-9}$ & $1 \times \tan ^{-{ }^{27}}$ \\
\hline 2,2 on & Packayest wistats & EY WRADtit & 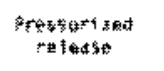 & thes: & $7,8,11=b$ & $1 \times 10^{-5}$ & $\left\{\times 1 \mathfrak{w}^{-\mathrm{A}_{\mathrm{t}}}\right.$ & $5: w^{-3}$ & 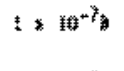 \\
\hline 3. & 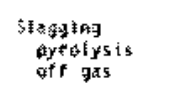 & 361 & Explosten & Gedstitiet & 1 te.11:0 & $2 x \times 10^{-5}$ & $\$ \times 10^{* 3}$ & $z \times 10^{* 3}$ & $A \times 13^{-2} z_{E}$ \\
\hline $3.2 \mathrm{ct}$ 維数 & Parkatali asste & 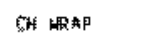 & pits & br明 & 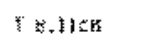 & $5 * x^{-12}$ & 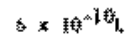 & $2 \times 10^{-1 t}$ & $5: x^{2}$ \\
\hline \multicolumn{10}{|c|}{ 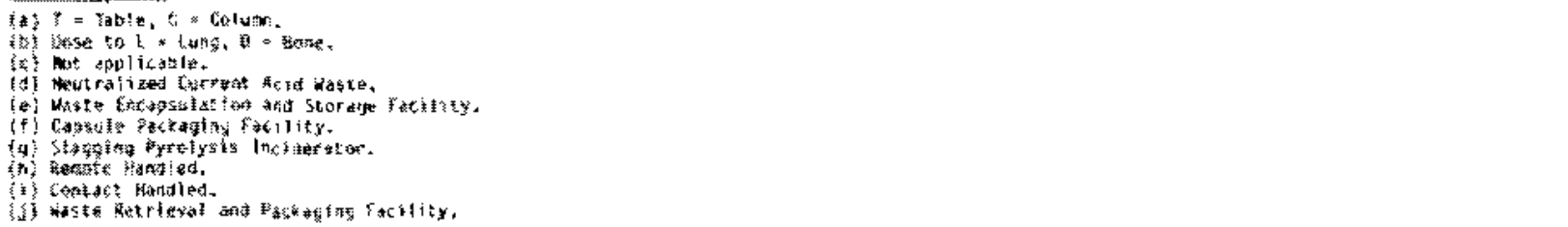 } \\
\hline
\end{tabular}


IABLE 10.4b. Geologic Disposal Alternative Potential Doses from Accidental Releases for 0perations Involving Six Waste Forms (Max. Ind. Ingestion)

\begin{tabular}{|c|c|c|c|c|c|c|c|c|}
\hline & \multirow[b]{2}{*}{ Waste Fon } & \multirow[b]{2}{*}{ factility } & \multirow[b]{2}{*}{ Accident } & \multirow[b]{2}{*}{ Location } & \multicolumn{4}{|c|}{$\frac{\text { Maximun Individudi oose, (b) ren }}{\text { Paximon ingestion }}$} \\
\hline & & & & & $\frac{\text { Ist Ye }}{\text { T. Body }}$ & $\frac{\text { ar Dose }}{\text { C, Organ }}$ & 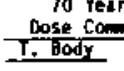 & $\begin{array}{l}\text { it Dose } \\
\text {-1tent } \\
\text { C. Urown }\end{array}$ \\
\hline \multicolumn{9}{|l|}{ Exysting Tank Waste? } \\
\hline 1. Mechantcal retrieval & Salt cake & mobile platform & Explosion & Waste Tank & $6 \times 10^{-2}$ & $2 \times 10^{-1} \mathrm{~B}$ & $1 \times 10^{0}$ & $5 \times 10^{0} 8$ \\
\hline 2. Hydraulic retrieval & Solt cake & $m(c)$ & $\begin{array}{l}\text { Pressurized } \\
\text { release }\end{array}$ & $\begin{array}{l}\text { Diversion } \\
\text { value }\end{array}$ & $2 \times 10^{-2}$ & $8 \times 10^{-2} B$ & $5 \times 10^{-1}$ & $2 \times 10^{0} 8$ \\
\hline \multicolumn{9}{|l|}{$\begin{array}{l}\text { 3. Sr, Cs, Tc removal } \\
\text { (radionuclide } \\
\text { concentration) }\end{array}$} \\
\hline $\begin{array}{l}\text { 3.1 sludge vashing. } \\
\text { solidiliquid } \\
\text { separation }\end{array}$ & sludge & $\begin{array}{l}\text { Sludge washing } \\
\text { canyon }\end{array}$ & filter fai lure & Filters & $3 \times 10^{-7}$ & $1 \times 10^{-6} \mathrm{~B}$ & $7 \times 10^{-6}$ & $\mathrm{~J} \times 10^{-5} \mathrm{~B}$ \\
\hline $\begin{array}{l}3.2 \text { Complexant } \\
\text { dest ruct ton }\end{array}$ & wo information av & tlable & & & & & & \\
\hline $\begin{array}{l}3.3 \text { Rodionuclilde } \\
\text { rewaydil }\end{array}$ & $\begin{array}{l}\text { Lon exchange } \\
\text { resing }\end{array}$ & $\begin{array}{l}\text { Radionuclide } \\
\text { concentration }\end{array}$ & $\begin{array}{l}\text { lon exchange } \\
\text { fyre }\end{array}$ & $\begin{array}{l}\text { Restin } \\
\text { columan }\end{array}$ & & & & \\
\hline $\begin{array}{l}\text { 4. 6lass mamabilization } \\
\text { (viterification) }\end{array}$ & Molten glass & $\begin{array}{l}\text { Glass } \\
\text { Inmobilization }\end{array}$ & $\begin{array}{l}\text { Loss of } \\
\text { fllters }\end{array}$ & filters & $2 \times 10^{-7}$ & $7 \times 10^{-7} B$ & $4 \times 10^{-6}$ & $1 \times 10^{-5} \mathrm{~B}$ \\
\hline $\begin{array}{l}\text { 5. Grout decontaminated } \\
\text { salt solutions }\end{array}$ & $\begin{array}{l}\text { Decontaninated } \\
\text { salt solutions }\end{array}$ & $\begin{array}{l}\text { Transpartable } \\
\text { grout }\end{array}$ & $\begin{array}{l}\text { Liquid spray } \\
\text { from line }\end{array}$ & $\begin{array}{c}\text { Transfer } \\
\text { line }\end{array}$ & $4 \times 10^{-13}$ & $1 \times 10^{-12}$ & $1 \times 10^{-12}$ & $5 \times 10^{-12} B$ \\
\hline $\begin{array}{l}\text { 6. Fill and cover expty } \\
\text { tank (dome fill) }\end{array}$ & $\begin{array}{c}\text { Residual tank } \\
\text { waste }\end{array}$ & Mone & Dame collapse & tank & $2 \times 10^{-3}$ & $5 \times 10^{-3} B$ & $3 \times 10^{-2}$ & $A \times 10^{-1} B$ \\
\hline \multicolumn{9}{|l|}{ Future Tank wste } \\
\hline 1. Retrieval & $\operatorname{MCAN}^{(d)}$ & $\mathrm{ma}$ & $\begin{array}{l}\text { Pressurized } \\
\text { release }\end{array}$ & $\begin{array}{l}\text { Diversion } \\
\text { value }\end{array}$ & $6 \times 10^{-2}$ & $1 \times 10^{-1} B$ & $5 \times 10^{1-}$ & $6 \times 10^{0} \mathrm{a}$ \\
\hline $\begin{array}{l}\text { 2. Solid/liquid } \\
\text { Separatian }\end{array}$ & CAM & $\begin{array}{l}\text { Sludge washing } \\
\text { canyon }\end{array}$ & $\begin{array}{l}\text { Filter } \\
\text { fallure }\end{array}$ & Filiters & $8 \times 10^{-7}$ & $2 \times 10^{-6} B$ & $7 \times 10^{-6}$ & $2 \times 10^{-5} \mathrm{~B}$ \\
\hline 3. $\underset{\text { renoval }}{\mathrm{Sr}, \mathrm{Cs}}$, Ic, IRU & $\begin{array}{l}\text { Ion exchange } \\
\text { resin }\end{array}$ & $\begin{array}{l}\text { Radionuclide } \\
\text { concentratian }\end{array}$ & $\begin{array}{l}\text { Ion exchange } \\
\text { fire }\end{array}$ & $\begin{array}{l}\text { Res in } \\
\text { columan }\end{array}$ & Insuff & "tcient Deto & & \\
\hline $\begin{array}{l}\text { 4. Grout decontaninated } \\
\text { Ilquid }\end{array}$ & $\begin{array}{l}\text { Decontaminated } \\
\text { Hquid }\end{array}$ & $\begin{array}{l}\text { Transportable } \\
\text { grout }\end{array}$ & $\begin{array}{l}\text { Liquid spray } \\
\text { fram line }\end{array}$ & $\begin{array}{l}\text { Transfer } \\
\text { line }\end{array}$ & $6 \times 10^{-13}$ & $2 \times 10^{-12} \mathrm{~B}$ & $2 \times 10^{-12}$ & $7 \times 10^{-12} \mathrm{~B}$ \\
\hline 5. Vitrification & molten glass & $\underset{\substack{\text { Glass } \\
\text { immabtlizat jan }}}{ }$ & $\begin{array}{l}\text { Loss of } \\
\text { filters }\end{array}$ & Filters & $3 \times 10^{-6}$ & $9 \times 10^{-6} B$ & $5 \times 10^{-5}$ & $2 \times 10^{-4} B$ \\
\hline $\begin{array}{l}\text { 6. Fill and caver empty } \\
\text { tant (dome f111) }\end{array}$ & $\underset{\substack{\text { Residual tank } \\
\text { waste }}}{\text { pas }}$ & Mone & Dome collapse & Tank & $4 \times 10^{-5}$ & $8 \times 10^{-5} B$ & $4 \times 10^{-4}$ & $1 \times 10^{-3} B$ \\
\hline \multicolumn{9}{|c|}{ Strontiue and Cestum Capsules } \\
\hline 1. Remoye from UE $5 F(e)$ & $\begin{array}{l}\text { Encapsulated } \\
\text { waste }\end{array}$ & wesf & Capsule drop & $\begin{array}{l}\text { Storage } \\
\text { area }\end{array}$ & $\begin{array}{l}9 \times 10^{-8} \\
8 \times 10^{-8}\end{array}$ & $\begin{array}{lll}3 \times & \times 10^{-7} \mathrm{~B} \\
8 & \times & 10^{-8}\end{array}$ & $\begin{array}{l}2 \times 10^{-6} \\
1 \times 10^{-7}\end{array}$ & $7 \times 10^{-6} \mathrm{\theta}$ \\
\hline 2. Capsule packaging & $\begin{array}{l}\text { Encapsulated } \\
\text { naste }\end{array}$ & $\operatorname{CPF}(F)$ & $\begin{array}{r}\text { Machinery } \\
\text { impacts } \\
\text { capsule }\end{array}$ & $\begin{array}{l}\text { "Load" } \\
\text { station }\end{array}$ & $\begin{array}{l}x \times 10^{-8} \\
\times 10^{-8}\end{array}$ & $\begin{array}{l}4 \times 10^{-8} 8 \\
1 \times 10^{-8}\end{array}$ & $\begin{array}{l}2 \times 10^{-7} \\
2 \times 10^{-8}\end{array}$ & $\begin{array}{l}9 \times 10^{-7} \mathrm{~B} \\
2 \times 10^{-8}\end{array}$ \\
\hline
\end{tabular}


TABLE 10.4D. (contd)

ב-maximul Individual cose (D) ren

\begin{tabular}{|c|c|c|c|c|c|c|c|c|}
\hline \multirow{3}{*}{ IRU-Contaninated Sall } & \multirow[b]{2}{*}{ Waste form } & \multirow[b]{2}{*}{ facilitity. } & \multirow[b]{2}{*}{ Accident } & \multirow{2}{*}{ Latation } & \multicolumn{4}{|c|}{ 二- Waxinut Ingtsito } \\
\hline & & & & & \multicolumn{4}{|c|}{ 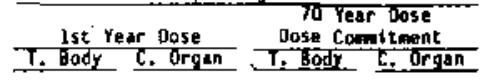 } \\
\hline & \multirow[b]{2}{*}{$-e_{\text {soll }}^{\text {Cont aminated }}$} & \multirow[b]{2}{*}{$\begin{array}{l}\text { Retrieval } \\
\text { facility }\end{array}$} & \multirow[b]{2}{*}{ Exploston } & \multirow[b]{2}{*}{$\begin{array}{l}\text { Battery } \\
\text { charg:ng } \\
\text { orea }\end{array}$} & & & & \\
\hline I. Retrieye & & & & & $3 \times 10^{-11}$ & $4 \times 10^{-10_{B}}$ & $2 \times 10^{-9}$ & $4 \times 10^{-8} 8$ \\
\hline 2. Process & $\begin{array}{l}\text { Slagging } \\
\text { pyrolys is } \\
\text { off gas }\end{array}$ & $\operatorname{sp|}\{g\}$ & Explosion & Gastfier & $3 \times 10^{-10}$ & $4 \times 10^{-9} \theta$ & $2 \times 10^{-8}$ & $A \times 10^{-7} B$ \\
\hline \multicolumn{9}{|l|}{ Pre-1970 IRU Solla Waste } \\
\hline 1. Retrieve & $\begin{array}{l}\text { [ontaminated } \\
\text { soli/waste }\end{array}$ & $\begin{array}{l}\text { Retriersl } \\
\text { factilty }\end{array}$ & Explasion & $\begin{array}{l}\text { Battery } \\
\text { charging } \\
\text { area }\end{array}$ & $9 \times 10^{-8}$ & $1 \times 10^{-7} \mathrm{~B}$ & $5 \times 10^{-7}$ & $2 \times 10^{-6} g$ \\
\hline $\begin{array}{l}\text { 2. Sorting and related } \\
\text { aperations }\end{array}$ & Packaged kaste & $5 P 3$ & $\begin{array}{l}\text { Pressurized } \\
\text { release }\end{array}$ & Drum & $3 \times 10^{-12}$ & $4 \times 10^{-12} z_{0}$ & $2 \times 10^{-11}$ & $5 \times 10^{-11} \mathrm{~B}_{\mathrm{B}}$ \\
\hline 3. 9rocess & $\begin{array}{l}\text { Slagging } \\
\text { pyralysis } \\
\text { off gas }\end{array}$ & SPI & Explosion & Gasifier & $1 \times 10^{-6}$ & $5 \times 10^{-6} 8$ & $3 \times 10^{-5}$ & $J \times 10^{-4} \mathrm{~B}$ \\
\hline \multicolumn{9}{|c|}{ Retrleyably stored and Heviy cenerdted IRU } \\
\hline 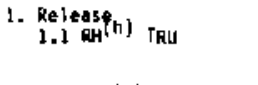 & Packayed waste & $\begin{array}{l}\text { Cayssan } \\
\text { retrieval }\end{array}$ & $\begin{array}{l}\text { Pressurized } \\
\text { release }\end{array}$ & Metal can & $1 \times 10^{-12}$ & $2 \times 10^{-12} z_{\theta}$ & $7 \times 10^{-12}$ & $2 \times 10^{-11} 1_{8}$ \\
\hline 1.2. $\mathrm{CH}^{(1)} \mathrm{TRU}$ & Packaged waste & mone & $\begin{array}{l}\text { Pressurized } \\
\text { release }\end{array}$ & Orum & $5 \times 10^{-5}$ & $1 \times 10^{-4} \mathrm{~B}$ & $5 \times 10^{-4}$ & $2 \times 10^{-3} \mathrm{~B}$ \\
\hline $\begin{array}{l}\text { 2. Sorting and Related } \\
\text { Operations } \\
2.1 \text { KH FRU }\end{array}$ & Packayed maste & SPI & $\begin{array}{l}\text { Pressurfized } \\
\text { release }\end{array}$ & Orum & $6 \times 10^{-11}$ & $1 \times 10^{-10_{B}}$ & $4 \times 10^{-10}$ & $1 \times 10^{-9} B$ \\
\hline $\begin{array}{l}2.2 \mathrm{CH} \mathrm{TRU} \\
\text { 3. Process }\end{array}$ & Packaged waste & $C H \operatorname{map}(j)$ & $\begin{array}{l}\text { Pressuryzed } \\
\text { release }\end{array}$ & Orum & $4 \times 10^{-12}$ & $9 \times 10^{-12_{B}}$ & $4 \times 10^{-11}$ & $2 \times 10^{-10^{B}}$ \\
\hline 3.1 & $\begin{array}{l}\text { Slagging } \\
\text { pyrolysis } \\
\text { off gas }\end{array}$ & SPI & Explasian & Gasifler & $2 \times 10^{-5}$ & $3 \times 10^{-5} \mathrm{~g}$ & $1 \times 10^{-4}$ & $4 \times 10^{-4} B$ \\
\hline 3.2 CH WRAP & Packaged maste & CH waP & fire & Drum & $2 \times 10^{-13}$ & $4 \times 10^{-13} B$ & $2 \times 10^{-12}$ & $9 \times 10^{-12} \mathrm{~B}$ \\
\hline
\end{tabular}

a) T - Table, c - Colum.

(a) Dose to $L$ - L Lung, $\theta$ = Bane,
not app licalile.

Meutral ized Current Acid Haste.
Waste Encapsulation and Storage Facility.

Capsule Packaging factlity.

hemote Handled.

(i) Contact Handled. 
TABLE 10.4C. Geologic Disposal Alternative Potential Doses from Accidental Releases for Operations Involving Six Waste Forms (Total Population Dose)

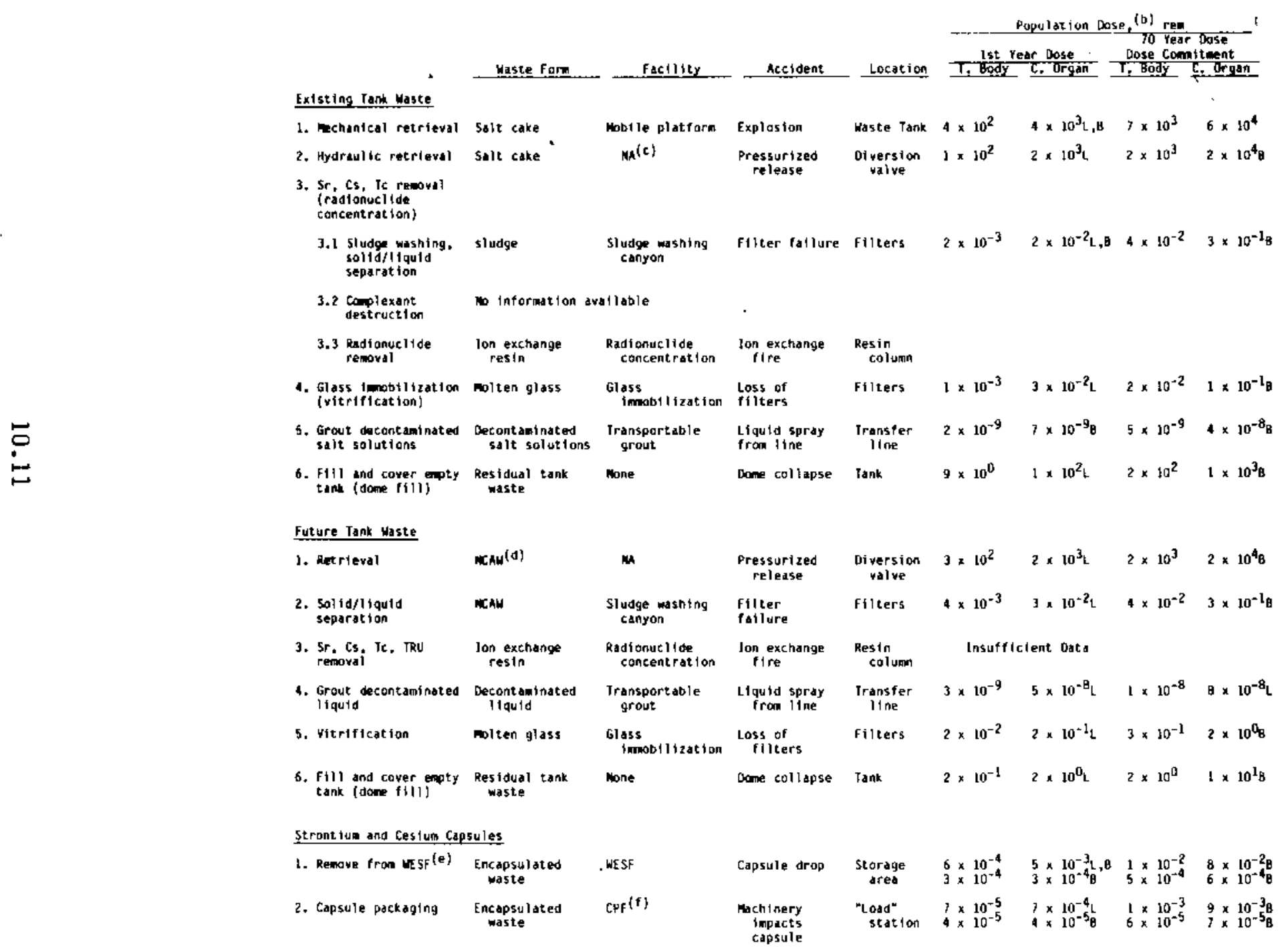


TABLE $10.4 \mathrm{c} . \quad$ (contd)

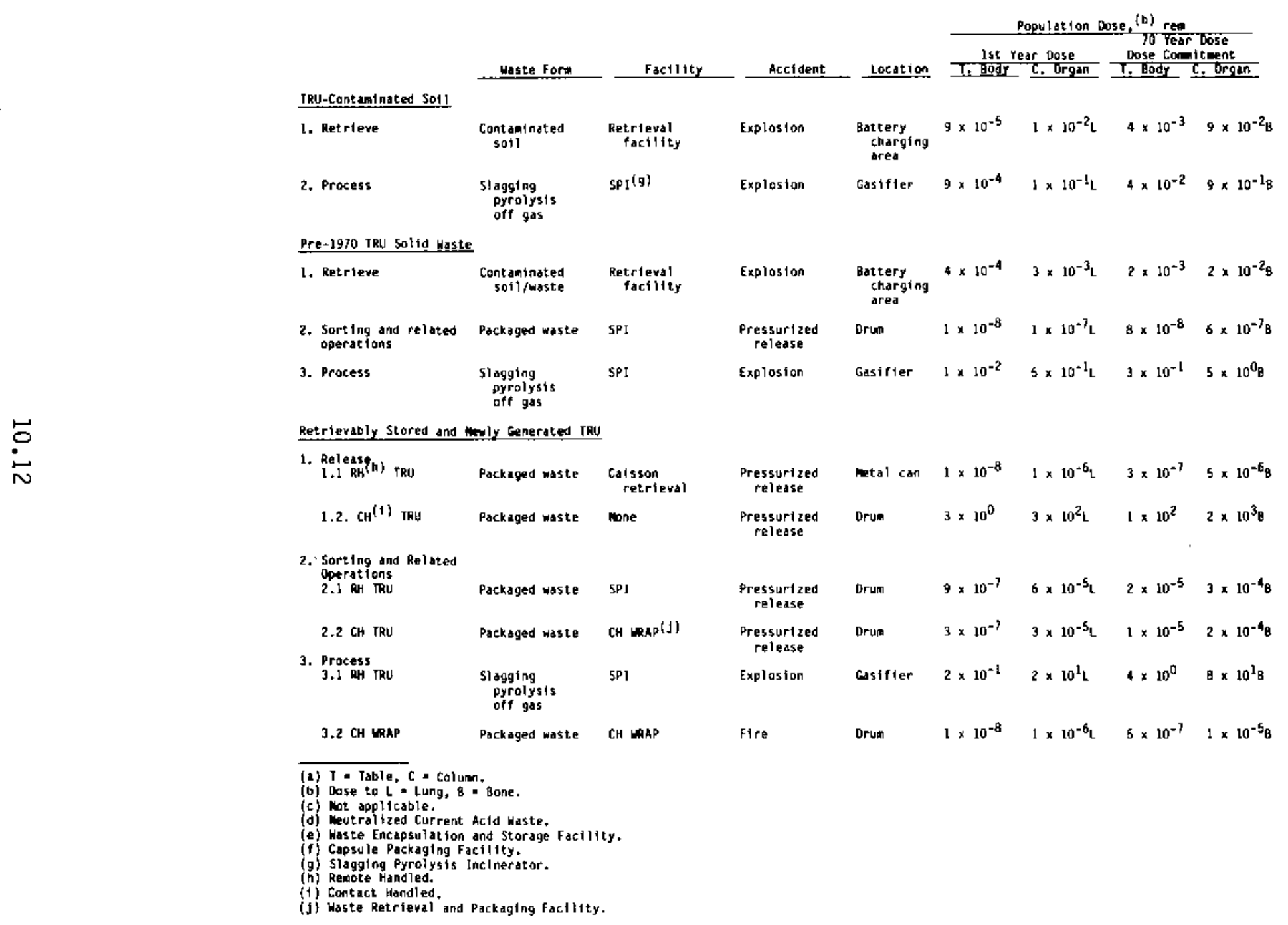


10.5.2 Radiation Doses Associated with the In-Place Stabilization Alternative

Twenty separate dose calculations were performed to analyze the potential radiological impact from the disposal of the Hanford Defense Wastes under the in-place stabilization and disposal alternative. The dose estimates, listed in Tables $10.5 \mathrm{a}, \mathrm{b}$, and $c$, are divided according to the maximally exposed individual inhalation dose, the maximally exposed individual ingestion dose, and the population dose. For each of these three categories the first year total body and critical organ dose, and the 70 year total body and critical organ dose commitment were calculated. The accident resulting in the greatest public dose was the ferrocyanide/organic explosion postulated for the handing of the single-shell tank wastes. This upper bound accident is the same as described for the geologic disposal alternative.

The accident with the second-highest radiological consequences is from the pressurized release of liquid waste due to failure of a diversion valve during hydraulic retrieval of the tank wastes. This accident is also the same as described in the geologic disposal alternative.

\subsubsection{Radiation Doses Associated with the Reference Alternative} Disposal Action

Twenty-seven separate dose calculations were performed to analyze the potential radiological impact from the disposal of the Hanford Defense Wastes under the Reference Alternative. The dose estimates, 1isted in Tables 10.6a, $b$, and $c$, are divided according to the maximally exposed individual inhalation dose, the maximally exposed individual ingestion dose, and the population dose. For each of these three categories the first year total body and critical organ dose, and the 70 year total body and criticai organ dose commitment were calculated. The accident resulting in the greatest public dose was the ferrocyanide/organic explosion postulated for the handing of the single-shell tank wastes. This upper bound accident is the same as described for the geologic disposal alternative and for the in-place stabilization and disposal alternative.

The accident with the second-highest radiological consequences is from the pressurized release of liquid waste due to failure of a diversion valve during 
TABLE 10.5a. In-Place Stabilization and Disposal Alternative Doses from Accidental Releases for Operations Involving Six Waste Forms (Max. Ind* Inhalation)

\begin{tabular}{|c|c|c|c|c|c|c|c|c|c|}
\hline & \multirow[b]{3}{*}{ Waste form. } & \multirow[b]{3}{*}{ Facility } & \multirow[b]{3}{*}{ Accident } & \multirow[b]{3}{*}{ Location } & \multirow{3}{*}{$\begin{array}{l}\text { Reference (a) } \\
\text { Inventery }\end{array}$} & \multicolumn{4}{|c|}{$\frac{\text { Maxinun truividual cose, }}{\text { (b) }}$} \\
\hline & & & & & & Ist $\mathrm{Ye}$ & ar pose & $\begin{aligned} 70-t \\
\text { Dose Coin }\end{aligned}$ & mir \\
\hline & & & & & & T. Booy & c. ortan & T. Body & C. Organ \\
\hline \multicolumn{10}{|l|}{ Existing Tank Waste } \\
\hline 1. lory sifole-shell & Satio cak & Tank & Explosion & rank & I. & $9 \times 10^{-z}$ & $2 \times 10 \hat{0}_{\mathrm{L}}$ & $1 \times 10^{0}$ & $2 \times 10^{10}$ \\
\hline 2. fill tank dome & Sals & Tank & conte & ank & ${ }^{1} 3,16 z$ & 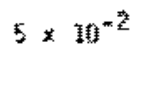 & 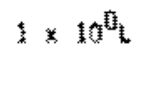 & $5 \times 10^{-1}$ & $1 \times 10^{1}$ \\
\hline 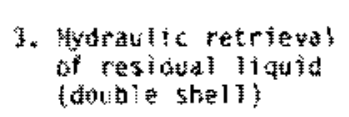 & Inquats waste & Tarik & $\begin{array}{l}\text { Presstartized } \\
\text { spray }\end{array}$ & $\begin{array}{l}\text { Oiversion } \\
\text { value }\end{array}$ & Ta,kz & $3 \times 10^{-2}$ & $7 \times 10^{21}+1$ & $4 \times 10^{-1}$ & $5 \times 10^{6}$ \\
\hline $\begin{array}{l}\text { 4. Complexant } \\
\text { destruction }\end{array}$ & \multicolumn{9}{|c|}{ No information available } \\
\hline 5. Sorsut & $\begin{array}{l}\text { Aquegus } \\
\text { solutions }\end{array}$ & $\begin{array}{c}\text { Franspartable } \\
\text { groust }\end{array}$ & $\begin{array}{l}\text { Liquid spray } \\
\text { from line }\end{array}$ & $\begin{array}{l}\text { Transter } \\
\text { line }\end{array}$ & $\mathrm{T} \cdot \mathrm{B}, 2 \mathrm{2}$ & $1 \times 10^{-11}$ & $2 \times 10^{-110}$ & $2 \times 19^{-10}$ & $2 \times 10^{-9} \mathrm{~B}$ \\
\hline 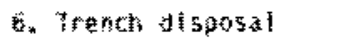 & \multicolumn{9}{|c|}{ 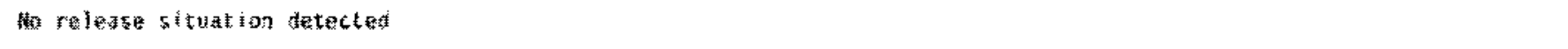 } \\
\hline 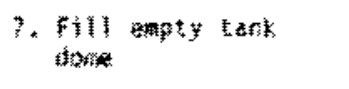 & 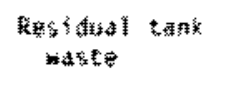 & we & $\begin{array}{l}\text { bomet } \\
\text { callage }\end{array}$ & Fank & a.ktz & $2 \times 10^{-3}$ & $5 \times 1 a^{-2} z_{2}$ & $3 \times 10^{-2}$ & $5 \times 10^{-1}$ \\
\hline \multicolumn{10}{|l|}{ future Tank waste } \\
\hline 1. Hytrantic retrieval & Liquid waste & Tank & $\begin{array}{l}\text { pressurized } \\
\text { spray }\end{array}$ & $\begin{array}{l}\text { Diversion } \\
\text { value }\end{array}$ & $18.3 a$ & $4 \times 10^{-2}$ & $1.5 \times 10^{6} \mathrm{~L}$ & $4 \times 10^{-1}$ & $3 \times 10^{0} B$ \\
\hline 2. Cessium removal & Litguid waste & 8 plant & $\begin{array}{l}\text { Ian cxechange } \\
\text { fire }\end{array}$ & $\begin{array}{l}\text { Restn } \\
\text { cotumi }\end{array}$ & \multicolumn{5}{|c|}{ Insufficient bat } \\
\hline 3. Cosium & 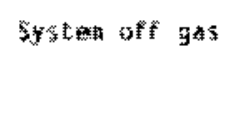 & B plant & 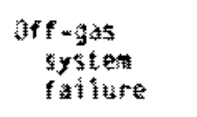 & Fititers & $13.3 a$ & $6 \times 10^{-6}$ & $1 \div 16^{4}+1$ & $6 \times 10^{-5}$ & $9 \times 1 n^{-4} \mathrm{k}$ \\
\hline 4. 6 atout & 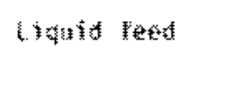 & $\begin{array}{l}\text { Transportatere } \\
\text { yrate }\end{array}$ & $\begin{array}{l}\text { spray from } \\
\text { feed line }\end{array}$ & $\begin{array}{l}\text { Trathefer } \\
\text { line }\end{array}$ & 18.463 & $1 \times 10^{-\mathrm{n} n}$ & $4 \times 10^{* 9} \mathrm{~L}$ & $3 \times 10^{-9}$ & $z * 10^{-6} \mathrm{~s}$ \\
\hline s. Bill tank & 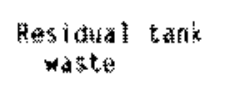 & tone & $\begin{array}{l}\text { Oome } \\
\text { collapse }\end{array}$ & Tank & $19.3 \%$ & $3 \times 10^{-5}$ & $8 \times 10^{-4} \mathrm{~h}$ & $3 \times 10^{-4}$ & $5 \times 10^{-3 / 3}$ \\
\hline
\end{tabular}


TABLE 10.5a. (cont $d$ )

\begin{tabular}{|c|c|c|c|c|c|c|c|c|c|}
\hline & \multirow[b]{3}{*}{ Waste Form } & \multirow[b]{3}{*}{ Facility } & \multirow[b]{3}{*}{ Accident } & \multirow[b]{3}{*}{ Location } & \multirow{3}{*}{$\begin{array}{l}\text { Reference } \\
\text { Inventory } \\
\end{array}$} & \multicolumn{4}{|c|}{$\frac{\text { Maximum Indtvidual Dose, }}{{ }^{(b)}}$, rem } \\
\hline & & & & & & lst Yea & ar Dose & $\begin{array}{r}70-Y 7 \\
\text { Cose Cont } \\
\end{array}$ & mitment \\
\hline & & & & & & T. Body & C. Organ & T. Body & C. Organ \\
\hline \multicolumn{10}{|c|}{ Strontium and Cesium Capsules } \\
\hline 1. Remove from WESF $(c)$ & $\begin{array}{l}\text { Encapsulated } \\
\text { waste }\end{array}$ & WESF & $\begin{array}{l}\text { Capsule } \\
\text { rupture }\end{array}$ & $\begin{array}{l}\text { Storage } \\
\text { area }\end{array}$ & $\begin{array}{l}\text { T } 8.5 c 3 \\
\text { T } 8.5 c 7\end{array}$ & $\begin{array}{l}1 \times 10^{-7} \\
2 \times 10^{-8}\end{array}$ & $\begin{array}{l}2 \times 10^{-6} \mathrm{~L} \\
2 \times 10^{-8}\end{array}$ & $\begin{array}{l}1 \times 10^{-6} \\
2 \times 10^{-8}\end{array}$ & $\begin{array}{l}2 \times 10^{-5} \mathrm{~B} \\
2 \times 10^{-8} \mathrm{~B}\end{array}$ \\
\hline 2. Capsule packaging & $\begin{array}{l}\text { Encapsulated } \\
\text { waste }\end{array}$ & $\mathrm{CPF}^{(\mathrm{d})}$ & $\begin{array}{c}\text { Machinery } \\
\text { impacts } \\
\text { capsules }\end{array}$ & $\begin{array}{l}\text { "Load" } \\
\text { Section }\end{array}$ & $\begin{array}{ll}T & 8.5 \mathrm{c} 3 \\
\mathrm{~T} & 8.5 \mathrm{c} 7\end{array}$ & $\begin{array}{l}1 \times 10^{-8} \\
2 \times 10^{-9}\end{array}$ & $\begin{array}{l}3 \times 10^{-7} \\
2 \times 10^{-9}\end{array}$ & $\begin{array}{l}2 \times 10^{-7} \\
2 \times 10^{-9}\end{array}$ & $\begin{array}{l}3 \times 10^{-6} \mathrm{~B} \\
3 \times 10^{-9} \mathrm{~B}\end{array}$ \\
\hline $\begin{array}{l}\text { 3. Place in drywell } \\
\text { storage }\end{array}$ & $\begin{array}{l}\text { Encapsulated } \\
\text { raste }\end{array}$ & DWSF $(e)$ & $\begin{array}{l}\text { Transporter } \\
\text { sheare } \\
\text { capsule }\end{array}$ & DWSF & $\begin{array}{l}\text { T } 8.5 \mathrm{c} 3 \\
\text { T } 8.5 \mathrm{c} 7\end{array}$ & $2 \times 10^{-4}$ & $\begin{array}{l}3 \times 10^{-4} \mathrm{~L} \\
2 \times 10^{-5} \mathrm{~B}\end{array}$ & $\begin{array}{l}2 \times 10^{-3} \\
3 \times 10^{-5}\end{array}$ & $\begin{array}{l}6 \times 10^{-3} 1 \\
3 \times 10^{-5} \mathrm{~B}\end{array}$ \\
\hline \multicolumn{10}{|l|}{ IRU-Contaminated Sail } \\
\hline 1. Inject grout & $\begin{array}{l}\text { TRU-cont aminated } \\
\text { soil }\end{array}$ & None & $\begin{array}{l}\text { Void space } \\
\text { collapse }\end{array}$ & CRIB & $\mathrm{T} 8.7 \mathrm{c} 2$ & $2 \times 10^{-8}$ & $3 \times 10^{-6} \mathrm{~L}$ & $9 \times 10^{-7}$ & $2 \times 10^{-5_{B}}$ \\
\hline \multicolumn{10}{|l|}{ Pre-1970 TRU Solid Waste } \\
\hline 1. Grout caissons & Caisson & None & $\begin{array}{l}\text { Equipment } \\
\text { failure }\end{array}$ & Caisson & T $8.10 \mathrm{c} 2$ & $2 \times 10^{-11}$ & $2 \times 10^{-9} L$ & $6 \times 10^{-10}$ & $1 \times 10^{-8} \mathrm{~B}$ \\
\hline 2. Subsidence control & $\begin{array}{l}\text { Solid waste } \\
\text { site }\end{array}$ & None & $\begin{array}{l}\text { Void space } \\
\text { collapse }\end{array}$ & $\begin{array}{r}\text { Burial } \\
\text { site }\end{array}$ & $\mathrm{T} 8.10 \mathrm{c} 2$ & $2 \times 10^{-7}$ & $1 \times 10^{-5} \mathrm{~L}$ & $5 \times 10^{-6}$ & $1 \times 10^{-4} B$ \\
\hline \multicolumn{10}{|c|}{ Retrievably Stored and Newly Generated TRU } \\
\hline 1. Subsidence control & $\begin{array}{l}\text { Retrievable } \\
\text { stored TRUJ }\end{array}$ & None & $\begin{array}{l}\text { Void space } \\
\text { collapse }\end{array}$ & $\begin{array}{r}\text { Burial } \\
\text { site }\end{array}$ & T $8.11 \mathrm{c} 6$ & $4 \times 10^{-6}$ & $4 \times 10^{-4} L$ & $9 \times 10^{-5}$ & $2 \times 10^{-3} \mathrm{~B}$ \\
\hline 2. Bury packaged waste & TRU maste & None & $\begin{array}{l}\text { Package } \\
\text { breach }\end{array}$ & $\begin{array}{r}\text { Burial } \\
\text { site }\end{array}$ & T 8.1166 & $2 \times 10^{-3}$ & $2 \times 10^{-1} \mathrm{~L}$ & $4 \times 10^{-2}$ & $8 \times 10^{-1} B$ \\
\hline \multicolumn{10}{|c|}{$\begin{array}{l}\text { (a) } \mathrm{I}=\text { Table, } \mathrm{C}=\text { Column. } \\
\text { (b) Dose to } \mathrm{L}=\text { Lung, } \mathrm{B}=\text { Bone. } \\
\text { (c) Waste Encapsulation and Packaging Facitity. } \\
\text { (d) Capsule Packaging Facility. } \\
\text { (e) Dry Well Storage Facility. }\end{array}$} \\
\hline
\end{tabular}


TABLE 10.5b. In-Place Stabilization and Disposal Alternative Doses from Accidental Releases for Dperations Involving Six Waste Forms (Max. Ind. Ingestion)

\begin{tabular}{|c|c|c|c|c|c|c|c|c|}
\hline \multirow{3}{*}{ Existing tank Saste } & \multirow[b]{3}{*}{ Waste Form } & \multirow[b]{3}{*}{ Sacilicy } & \multirow[b]{3}{*}{ Accident } & \multirow[b]{3}{*}{ fostator } & \multicolumn{4}{|c|}{ 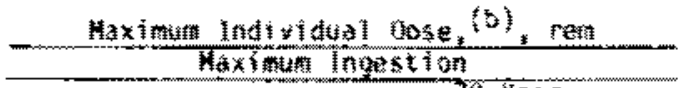 } \\
\hline & & & & & \multirow{2}{*}{\multicolumn{2}{|c|}{$\frac{\text { lst year pose }}{\text { T. Body }}$}} & \multicolumn{2}{|c|}{$\begin{array}{l}\text { 70-Year } \\
\text { Bose Comituent }\end{array}$} \\
\hline & & & & & & & In Gody & C. Orxisen \\
\hline $\begin{array}{l}\text { 1. Dry single-shell } \\
\text { tanks }\end{array}$ & Salt cake & Tank & Explosion & rank & $6 \times 10^{-2}$ & $2 \times 10^{-1} 1_{B}$ & $1 \times 10^{0}$ & $5 \times 10^{0} 0$ \\
\hline 2. Pill tank done & Salt calke & $\tan x$ & $\begin{array}{l}\text { Dafae } \\
\text { sal I apses }\end{array}$ & rank & $4 \times 10^{-2}$ & $1 \times 10^{m-1}$ & $g \times 10^{-1}$ & $3 \times 10^{6} y^{3}$ \\
\hline 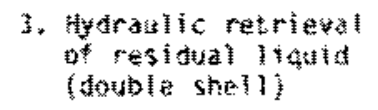 & Giquita *aste & Tank & $\begin{array}{l}\text { Pressurized } \\
\text { spray }\end{array}$ & 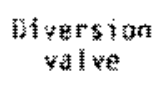 & $2 \times \mathrm{H}^{-2}$ & $n \times 10^{-2}$ & $5 \times 10^{-1}$ & $2 \times 10^{0}$ \\
\hline $\begin{array}{l}\text { a. Eunplexan: } \\
\text { destrution }\end{array}$ & \multicolumn{2}{|c|}{ Wo infarmation avalatele } & & & & & & \\
\hline 5. Grout & $\begin{array}{l}\text { Aqueous } \\
\text { solutions }\end{array}$ & $\begin{array}{l}\text { Transportabie } \\
\text { grout }\end{array}$ & $\begin{array}{l}\text { Liquid spray } \\
\text { from line }\end{array}$ & $\begin{array}{l}\text { Transfer } \\
\text { line }\end{array}$ & $2 \times 10^{-11}$ & $5 \times 10^{-11} I_{B}$ & $? \times 10^{-10}$ & $7 \times 10^{-10} 0_{B}$ \\
\hline 5. Trench disposa? & \multicolumn{2}{|c|}{ No redede situation detected } & & & & & & \\
\hline $\begin{array}{l}\text { 7. Fill andty tark } \\
\text { tone }\end{array}$ & 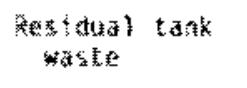 & Hone & $\begin{array}{l}\text { tane } \\
\text { callapst }\end{array}$ & Tank & $2 \times 10^{-3}$ & $6 \times 10^{-3}{ }^{3}$ & $4 \times 10^{-2}$ & $1 \times 10^{-1}$ \\
\hline \multicolumn{9}{|l|}{ Future Tonk hasta } \\
\hline 1. fydralitic retrieval & Hiquid waste & 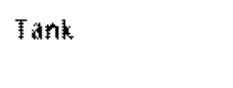 & $\begin{array}{l}\text { Pressurized } \\
\text { spray }\end{array}$ & $\begin{array}{l}\text { arversion } \\
\text { valye }\end{array}$ & $6 \times 10^{-2}$ & $I * 10^{+1} \theta$ & $5 \times 10^{-1}$ & $6 \times 10^{0} \mathrm{~B}$ \\
\hline 2. Custum removal & Liquid waste & B plant & $\begin{array}{l}\text { Ion exchange } \\
\text { fire }\end{array}$ & $\begin{array}{l}\text { Resint } \\
\text { colutan }\end{array}$ & \multicolumn{2}{|c|}{ Insufficient Data } & & \\
\hline $\begin{array}{l}\text { 3. Cestim } \\
\text { encapsitation }\end{array}$ & Systenin off was & B plant & $\begin{array}{l}\text { off-yas } \\
\text { systemen } \\
\text { failure }\end{array}$ & Filters & $8 \times 10^{-5}$ & $2 \times 10^{-\frac{5}{3}}$ & $7 \times 10^{-5}$ & $2 * 1 \mathfrak{y}^{-4} \mathrm{y}$ \\
\hline 4. (a) & lifatid feed & 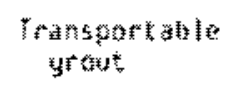 & $\begin{array}{l}\text { Soray from } \\
\text { feed lithe }\end{array}$ & 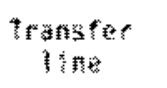 & $9 \times \mathrm{ln}^{-11}$ & $2 \times 10^{-1} \hat{n}_{8}$ & $1 \times 10^{-5}$ & $4 \times \mathrm{H}^{-9} \mathrm{~g}_{\mathrm{g}}$ \\
\hline 3. Fill tank & $\begin{array}{l}\text { Residual sank } \\
\text { watate }\end{array}$ & 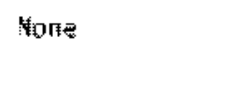 & $\begin{array}{l}\text { Done } \\
\text { coll apsé }\end{array}$ & Iatix & $4 \times 10^{-5}$ & $9 \times 10^{-\frac{5}{5}}$ & $4 \times 10^{-4}$ & $1 \times 20^{-3} B$ \\
\hline
\end{tabular}


IABLE 10.5b. (contd)

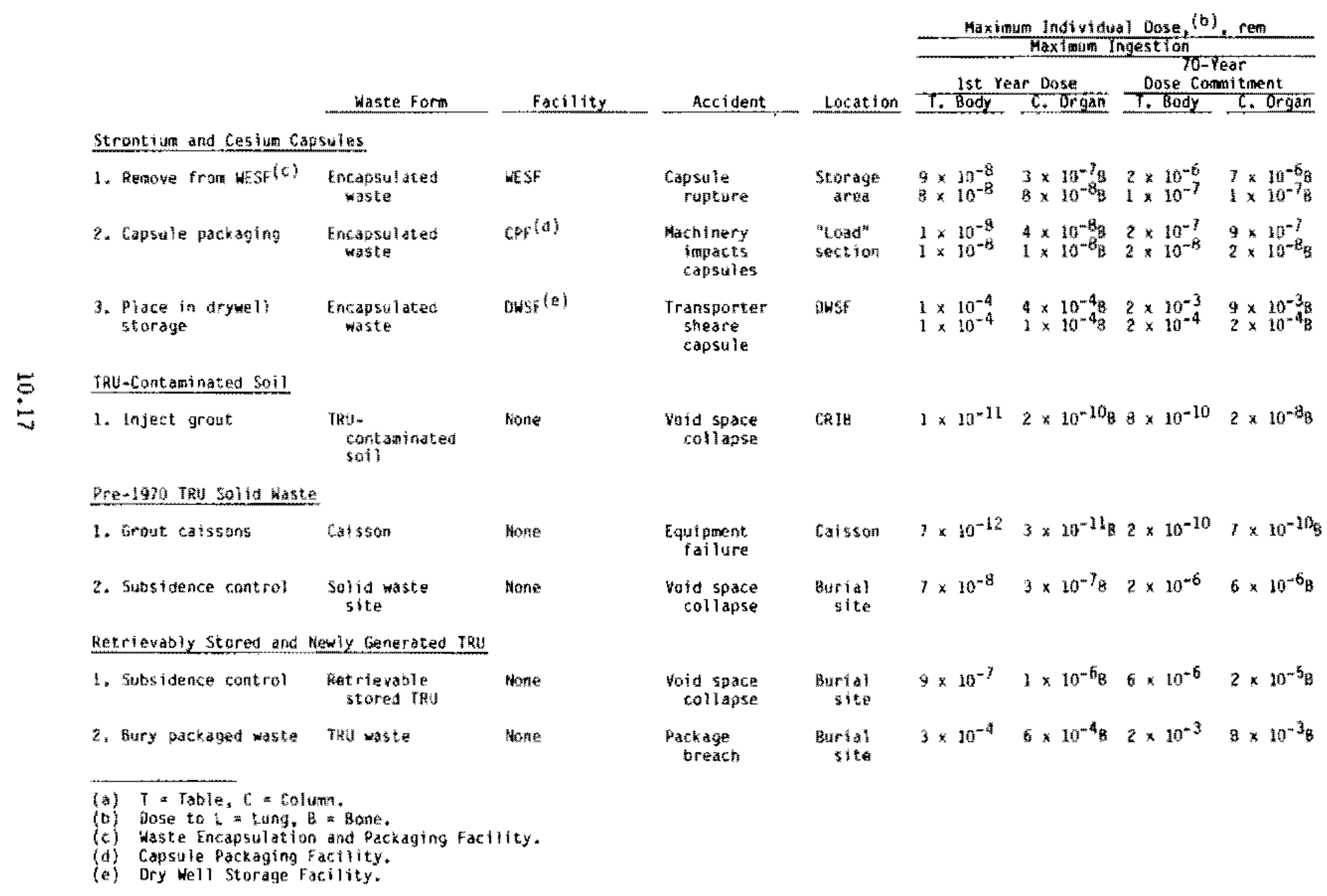


TABLE 10.5c. In-Place Stabilization and Disposal Alternative Doses from Accidental Releases for Operations Involving Six Waste Forms (Total Population Dose)

\begin{tabular}{|c|c|c|c|c|c|c|c|c|}
\hline \multirow{4}{*}{ Existing fank Haste } & \multirow[b]{3}{*}{ Haste tom } & \multirow[b]{3}{*}{ tacition } & \multirow[b]{3}{*}{ Accident } & \multirow{4}{*}{ Locartm } & \multicolumn{4}{|c|}{ Popularion Lose (b) man-ren } \\
\hline & & & & & \multirow{2}{*}{\multicolumn{2}{|c|}{ 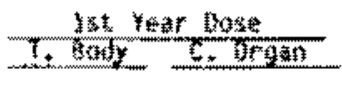 }} & \multicolumn{2}{|c|}{$\begin{array}{l}\text { 7om pest } \\
\text { gose comat inent } \\
\end{array}$} \\
\hline & & & & & & & & t. forgaff \\
\hline & & & & & & & & \\
\hline $\begin{array}{l}\text { 1. Dry single-shell } \\
\text { tanis }\end{array}$ & Seltckik & 辛推 & Explastion & 霜锥 & $4 * \ln ^{2}$ & $4 * 10^{3}$, & $3 * 10^{3}$ & $6 \times 10^{*} \mathrm{~B}$ \\
\hline 2. Fill tank tone & ate cake & $r_{\text {ank }}$ & $\begin{array}{l}\text { Oone } \\
\text { coll ipse }\end{array}$ & Tank & $2 * \cos ^{z}$ & $2 \times 10^{3}, 4$ & $4 \times 10^{3}$ & $3 \times 10^{4}$ \\
\hline 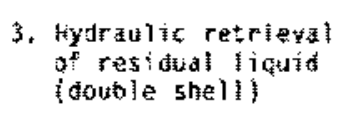 & 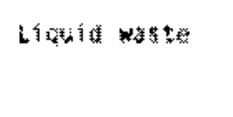 & rafik & $\begin{array}{l}\text { Pressurized } \\
\text { 5pray }\end{array}$ & $\begin{array}{c}\text { Diverston } \\
\text { vive }\end{array}$ & $1 \times 13^{2}$ & $2 \times 10^{3} \mathrm{~L}$ & $2 \times 10^{3}$ & $2 \times 10^{4}$ \\
\hline $\begin{array}{l}\text { 4. Complexant } \\
\text { destruction }\end{array}$ & \multicolumn{3}{|c|}{ Wo inforiataton avallabie } & & & & & \\
\hline 5. Grout & $\begin{array}{l}\text { Aqueaus } \\
\text { solutions }\end{array}$ & $\begin{array}{l}\text { Transportable } \\
\text { grout }\end{array}$ & $\begin{array}{l}\text { Liquid spray } \\
\text { from line }\end{array}$ & $\begin{array}{l}\text { Transfer } \\
\text { lines }\end{array}$ & $1 \times 1.1)^{-7}$ & $6 \times 10^{-1} L, B$ & $1 \times 10^{+6}$ & $8 \times 10^{-5} B$ \\
\hline 6. Trench disposa! & \multicolumn{3}{|c|}{ No ralease situation itetected } & & & & & \\
\hline $\begin{array}{l}\text { i. Fili empty tank } \\
\text { denge }\end{array}$ & $\begin{array}{l}\text { Restidad tatik } \\
\text { waste }\end{array}$ & None & $\begin{array}{l}\text { Eromie } \\
\text { collapse }\end{array}$ & Tank & $9 \times 1 \theta^{n}$ & $1 \times 10^{2} \mathrm{k}$ & $2 \times 10^{2}$ & $1 \times 10^{3} \mathrm{~B}$ \\
\hline \multicolumn{9}{|l|}{ Future lank waste } \\
\hline 1. Hydratic retrieyal & Liquatax & 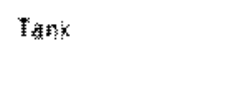 & $\begin{array}{l}\text { Pressurized } \\
\text { spray }\end{array}$ & $\begin{array}{l}\text { Giversion } \\
\text { value }\end{array}$ & $3 * 10^{2}$ & $2 * 10^{3} t_{x}$ & $2 \times 10^{3}$ & $2 \times 10^{4} b$ \\
\hline 2. Cesfum remotai & 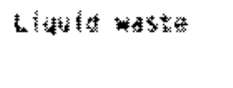 & e plant & $\begin{array}{l}\text { Ion: exchànge } \\
\text { Fire }\end{array}$ & $\begin{array}{l}\text { Resin } \\
\text { Eotuman }\end{array}$ & \multicolumn{2}{|c|}{ latsutheteat data } & & \\
\hline $\begin{array}{l}\text { 3. Cestian } \\
\text { encapstiakion }\end{array}$ & systeme an mas & A plant & $\begin{array}{l}\text { Off -ijas } \\
\text { systen } \\
\text { failufe }\end{array}$ & filters & $9 \times 10^{22}$ & $3 * \operatorname{los}^{-1} \mathrm{~L}$ & $a * \ln ^{-1}$ & $3 \times 10^{a_{2}}$ \\
\hline 4. Grout & Litustof fort & $\begin{array}{l}\text { Transportable } \\
\text { grout. }\end{array}$ & $\begin{array}{l}\text { Spray frota } \\
\text { feed line }\end{array}$ & $\begin{array}{l}\text { Trănsfar } \\
\text { linge }\end{array}$ & $4 \times 10^{* 3}$ & $1 \times 10^{-5} \mathrm{~L}_{\mathrm{m}}$ & $6 \times 10^{-6}$ & $5 \times 10^{-5} 6$ \\
\hline S. Fill zank & $\begin{array}{l}\text { nestidial kafik } \\
\text { waste }\end{array}$ & Martse & $\begin{array}{l}\text { Rione } \\
\text { coliapse }\end{array}$ & Infik & $2 \times 10^{-1}$ & $2 \times 10^{0}$ & $2 \times 10^{0}$ & $1 \times 10^{1} B$ \\
\hline
\end{tabular}


TAbLE $10.5 \mathrm{c} \cdot(\mathrm{conta})$

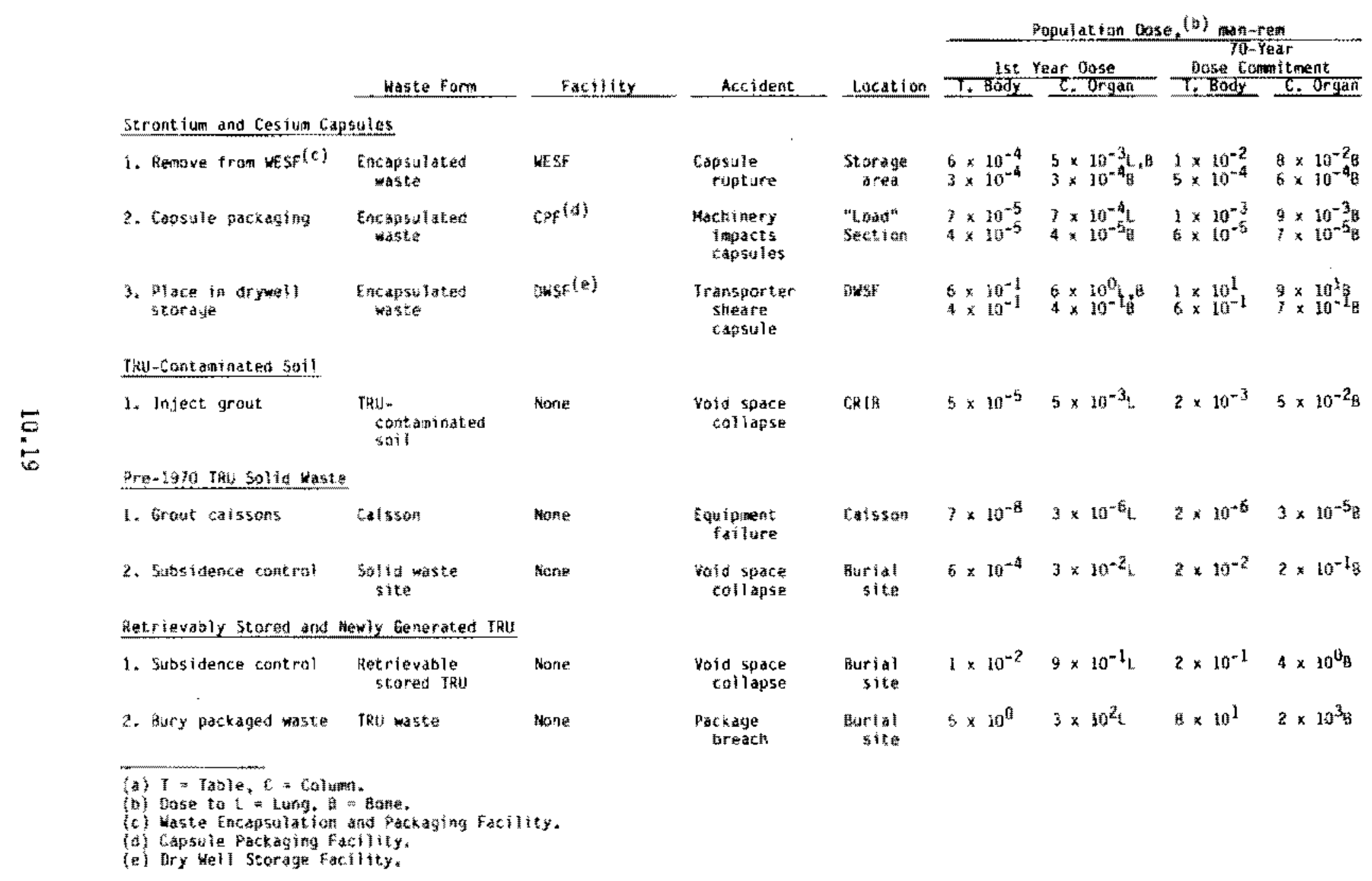


TABLE 10.6a. Reference Alternative Potential Doses from Accidental Releases for Operations Involving Six Waste Forms (Max. Ind. Inhalation)

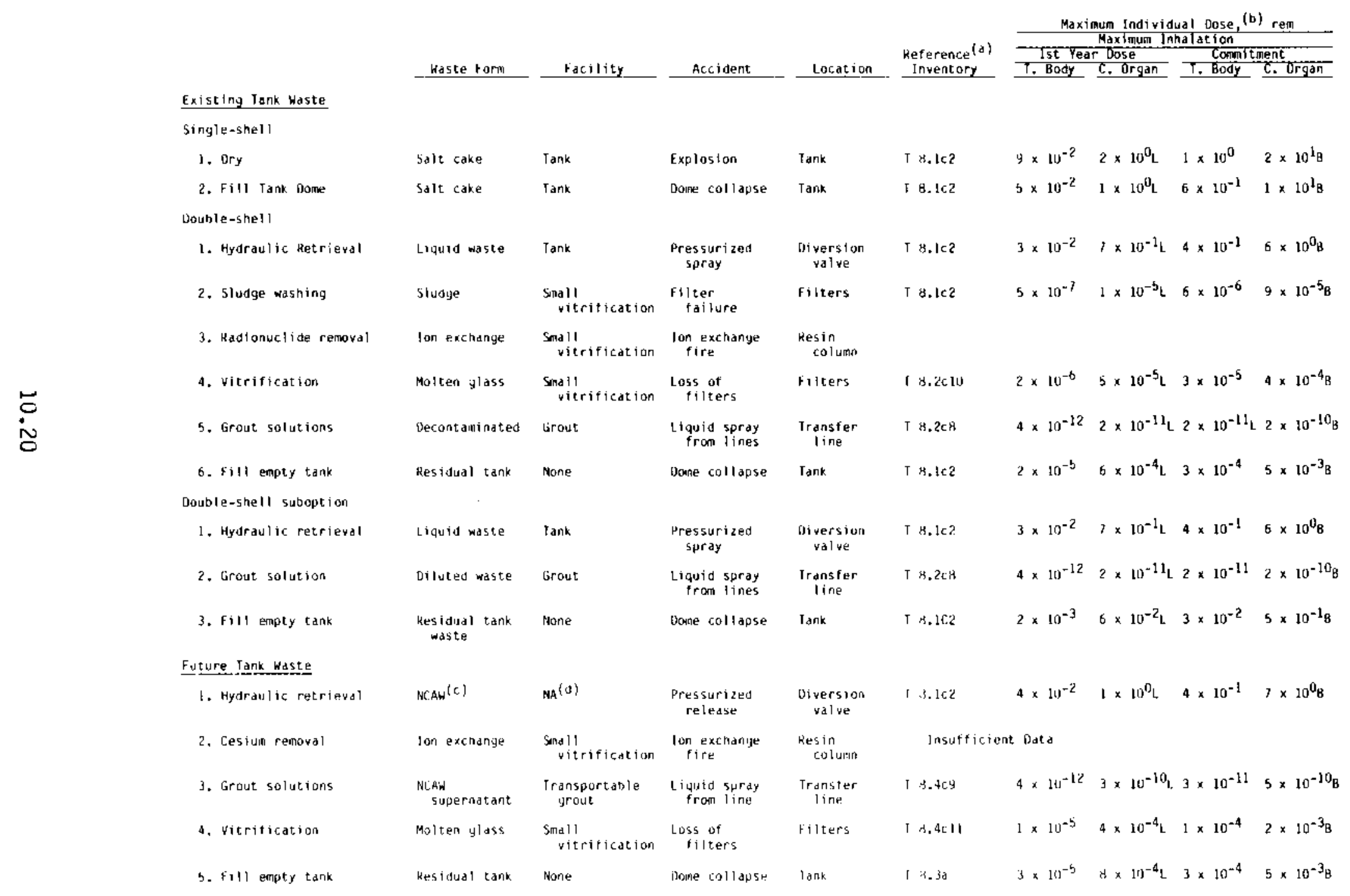




\section{TABLE 10.6a: (contd)}

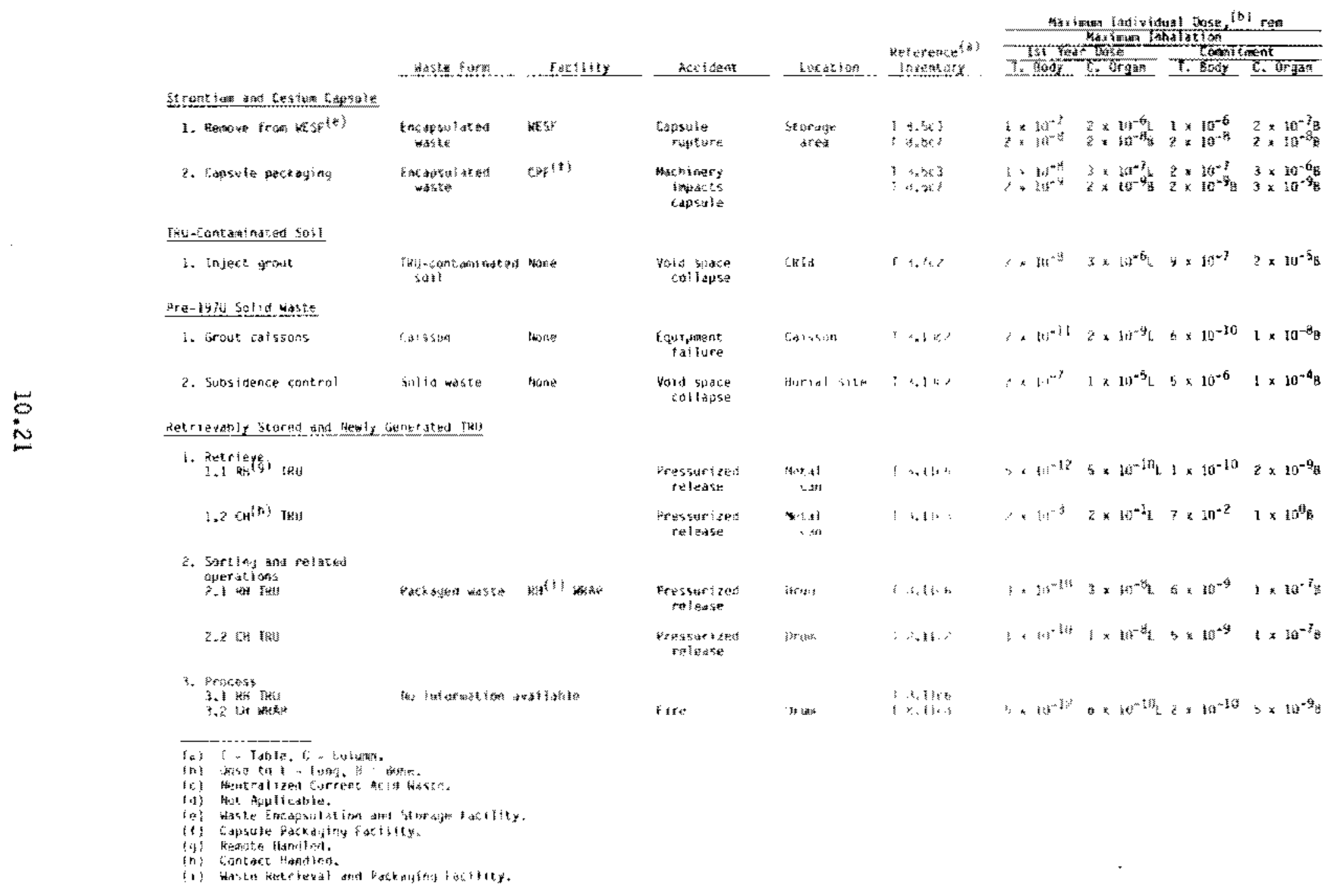


TABLE 10.6b. Reference Alternative Potential Doses from Accidental Releases for Operations Involving Six Waste Forms (Max. Ind. Ingestion)

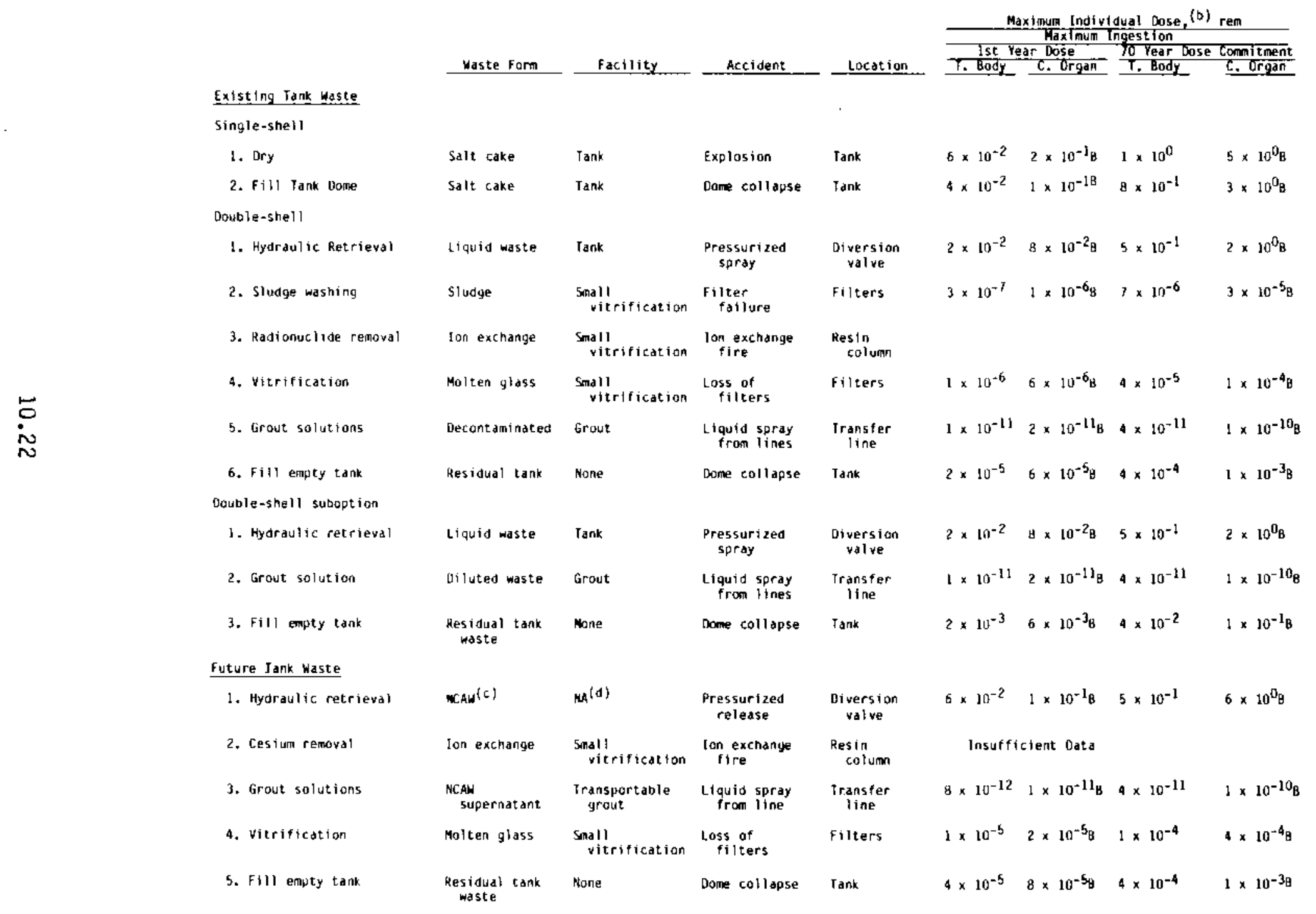


TABLE 10.60. (conta)

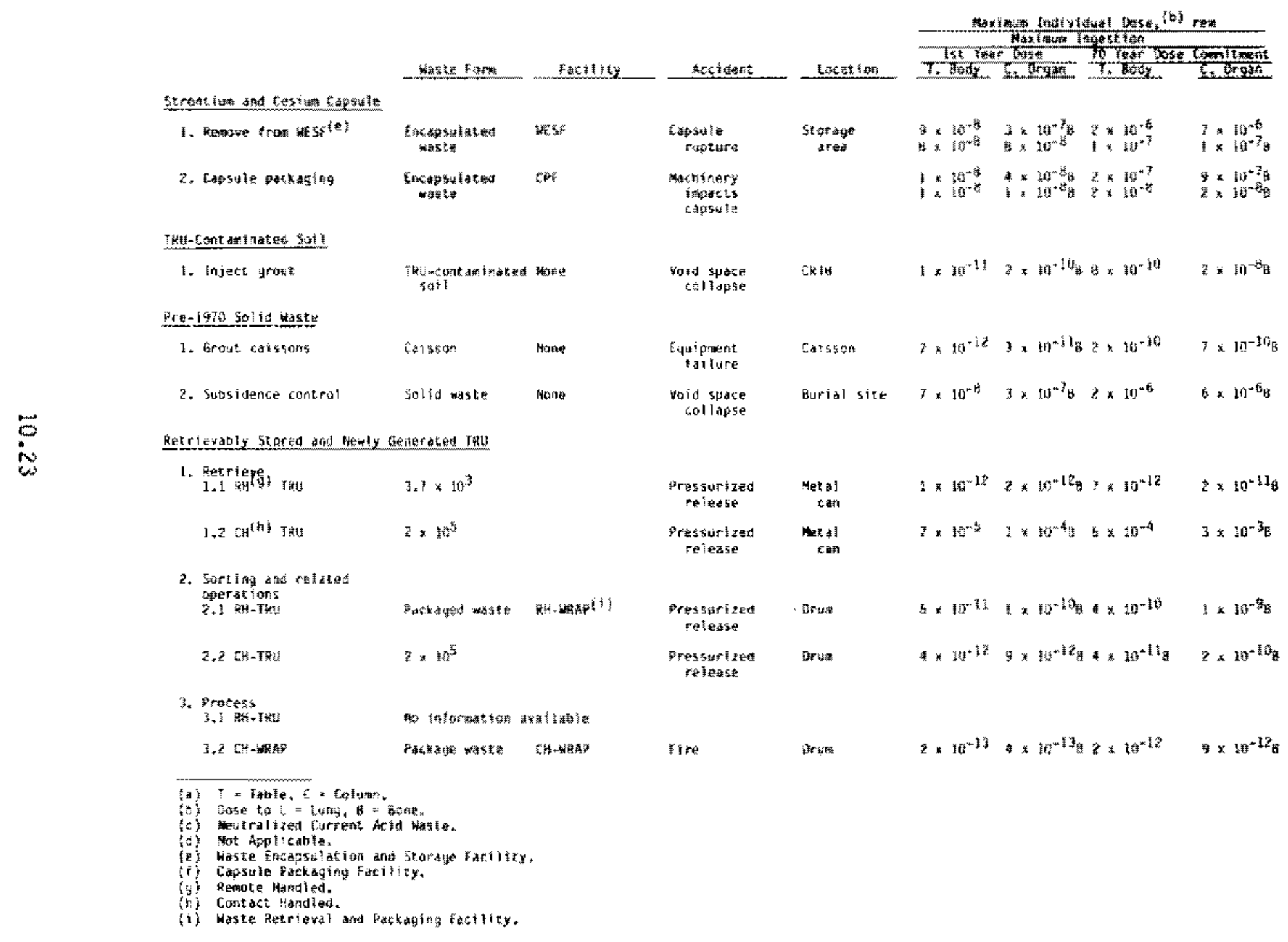


TABLE 10.6C. Reference Alternative Potential Doses from Accidental Releases for Operations Involving Six Waste Forms (Total Population Dose)

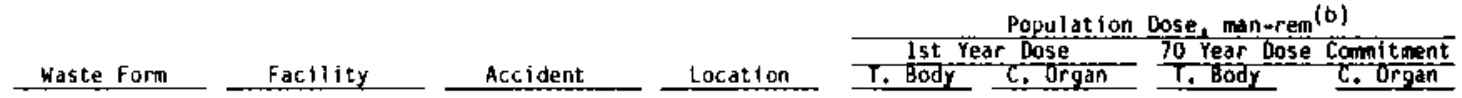

Existing Tank Waste

Single-shell

1. Dry

2. Fill Tank Dome

Salt cake Tank

Explositon

Tank

Salt cake Tank

Dome collapse

Tank

$4 \times 10^{2} \quad 4 \times 10^{3} \mathrm{~L}, \mathrm{~B} \quad I \times 10^{3}$

$6 \times 10^{4} B$

Double-shell

1. Hydraulic Retrieval

Liquild waste Tank

Pressurized

Diversion
value

$2 \times 10^{2} \quad 2 \times 10^{3} \mathrm{~L}, \mathrm{~B} \quad 4 \times 10^{3}$

$3 \times 10^{4} \mathrm{~B}$

2. Sludge washing

sluage

Small

F1lter

3. Radionuchide removal

Ion exchange

Small

Filters

$1 \times 10^{2} \quad 2 \times 10^{3} \mathrm{~L} \quad 2 \times 10^{3}$

$2 \times 10^{4}$

4. Vitrification

Molten glass

Small

Ion exchange

Resin

5. Grout solutions

6. Fill empty tank

Decontaminated Grout

Loss of
filters

Filters

$2 \times 10^{-3} \quad 2 \times 10^{-2} \mathrm{~L}, \mathrm{~B} \quad 4 \times 10^{-2} \quad 3 \times 10^{-1} \mathrm{~B}$

Double-shell suboption

Residual tank None

Liquid spray
from lines

Transfer
line

$1 \times 10^{-2} \quad 1 \times 10^{-1} L, B \quad 2 \times 10^{-1} \quad 1 \times 10^{0} B$

1. Hydraulic retrieval

Liquid waste Tank

Dome collapse

tank

Diluted waste Grout

Pressurized
spray

Diversion

Liquid spray

valve

$6 \times 10^{-8} \quad 1 \times 10^{-7} \mathrm{~B} \quad 2 \times 10^{-7}$

$B \times 10^{-7} \mathrm{~B}$

2. Grout solution

Residual tank None

from lines

Transfer

$1 \times 10^{-1} \quad 1 \times 10^{0} \mathrm{~L}, \mathrm{~B} \quad 2 \times 10^{0}$

$2 \times 10^{1} \mathrm{~B}$

3. Fill empty tank

Dome collapse

Tank

Future Tank Waste

1. Hydraulic retrieval

NCAW $(c)$ NA(d)

Pressurized reiease

Diversion

valve

$1 \times 10^{2} \quad 2 \times 10^{3} \mathrm{~L} \quad 2 \times 10^{3}$

$2 \times 10^{4} \mathrm{~B}$

Ion exchange

Small

Ion exchange

Reșin

NCAW
supernat ant

fire

3. Grout solutions

4. Vitrification

Molten ylass

Transportable Liquid spray

Transfer

Snlall

rom line

Transfer

$6 \times 10^{-8} \quad 1 \times 10^{-7} \mathrm{~B} \quad 2 \times 10^{-7} \quad 8 \times 10^{-7} \mathrm{~B}$

$9 \times 10^{0} \quad 1 \times 10^{2} \mathrm{~L} \quad 2 \times 10^{2} \quad 1 \times 10^{3} \mathrm{~B}$

5. Fill empty tank

Residual tank None

Loss of
filters

Filters

$3 \times 10^{2} \quad 2 \times 10^{3}$

$2 \times 10^{3}$

$2 \times 10^{4} B$

Insufficient Data

$4 \times 10^{-8} \quad 7 \times 10^{-7} \mathrm{~L} \quad 2 \times 10^{-7} \quad 2 \times 10^{-5} B$

$7 \times 10^{-2} \quad 1 \times 10^{0} \mathrm{~L} \quad 6 \times 10^{-1} \quad 5 \times 10^{0} \mathrm{~g}$

Dome collapse

Tank

$2 \times 10^{-1} \quad 2 \times 10^{0} \mathrm{~L} \quad 2 \times 10^{0} \quad 1 \times 10^{1} \mathrm{~B}$ 
TABLE 10.6c. (contd)

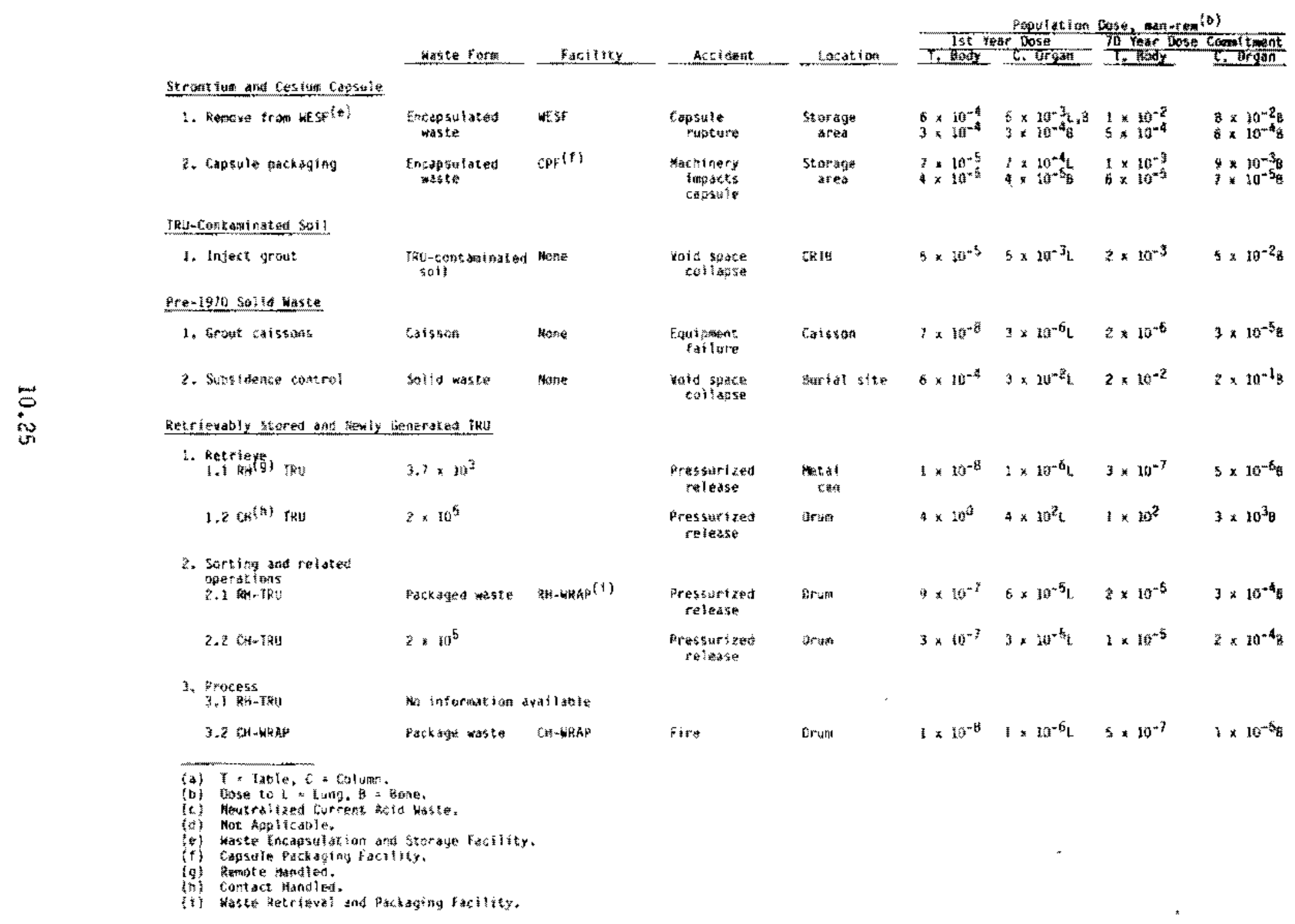


hydratic retrieval of the tank watses. This accident is also the 5 ane as described in the Geologic Disposal and In-place stabilization and otsposal Alternatives.

10.5.4 Radiation Doses Associated with the No Disposal Action Alternative

Thirteen separate dose calculations were performed to analyze the potenm tial radiological impact associated with the no disposal action alternatiave. The dose estimates, listed in Tables $10.7 \mathrm{a}, \mathrm{b}$, and $\mathrm{c}$, are divided according to the maximally exposed individual inhalation dose, the maximally exposed individual ingestion dose, and the population dose. For each of these three categories, the first year total body and critical organ dases, and the 70 -year total body and critical organ dose commitments were calculated. The accident resulting in the greatest public dose was the pressurized release of liquid waste due to fallure of a diversion valve during hydaulic retrieval operations. This upperbound acclaent is the sane as described for the existing double-shell and future tank wastes in the geologlc disposal alternative. The accident with the second-highest fadiological consequences is the collapse of void space over the retrievabiy stared and newly generated TRU wastes.

\subsubsection{Interpretation of the Radiological impact from the waste Disposal} Alternatives

The highest total body dose to a maximally exposed individual for any of the waste disposal alternatives was calculated to be 0.2 rem in the first year and 3 rem over a 70 -yr period. This dose is based on a summation of the ingestion and innalation pathways, which were calculated separately in order to maximize the dose estimate (and to provide an upper-bound estimate of potential dose). The dose received by an actual individual in the event of such an accident would, in all likelihood, be much lower. The anual, or first-year, dose of 0.2 ren is below the Dot guideline of 0.5 rem/yr to a member of the population from occasionala) releases at federal facilities. it is also equivalent

(a) Vaug, W, A. 1985. "Radiation Standards for Protection of the Public in the Vicinity of DoE Facilities." Department of Energy memorandum, August $5,1985$. 
to approximately twice the annul average background radiation dose received by a resident of the Tri-cities from naturally occurcing sources of radiation, such as cosmic rays (price et al. 1984 ). The accident resulting in the greatest public dose was the explosion of the single-shell tank wastes during retrieval or handing operations. It has been postulated that a layer containing ferrom or ferricyanide precipitates might be present in the single-shell tank wastes (Rockwel) 1980). Under certain conditions, this material could react explosively with nitrates present in the waste. If ferrocyanide precipitates are present, the potent 1 al for an explosion does exist. However, the presence of this material in quantities sufficient to produce a large explasion is still a subject of some debate (Rockwell 1980).

The rederal bovernment does not currently set liaits for the maximun dose that can be recelved by a population as a whole. Rather, it specifies an individual limit based on an average dose to a suitable sample of the exposed population; this litrit is one third the anount allowed for the individual at the point of maximum probable exposure. Consequently, one cannot compare the popum iation dose to a specific buc lintt. However, ti is possible to compare the estimated accidental dose to that which is routinely recelved by the satne group of individuals from natural sources of radiation. Approximately 140,000 persons were presumed to be exposed from the postulated upper-bound accidental releases. Their first-year dose was estimated to be 500 man-rent. This same group of individuals receives approximately 100 mrem aplece each year from natural sources of radiation; this calculates to be $1.410^{4}$ man-rem, or nearly thirty times the amount they might receive in the event of an accident during processing of the wastes fur disposal. 
TABLE 10.7a. No Disposal Action Alternative Potential Doses from Accidental Releases for Operations Involving Six Waste Forms (Max. Ind. Inhalation)

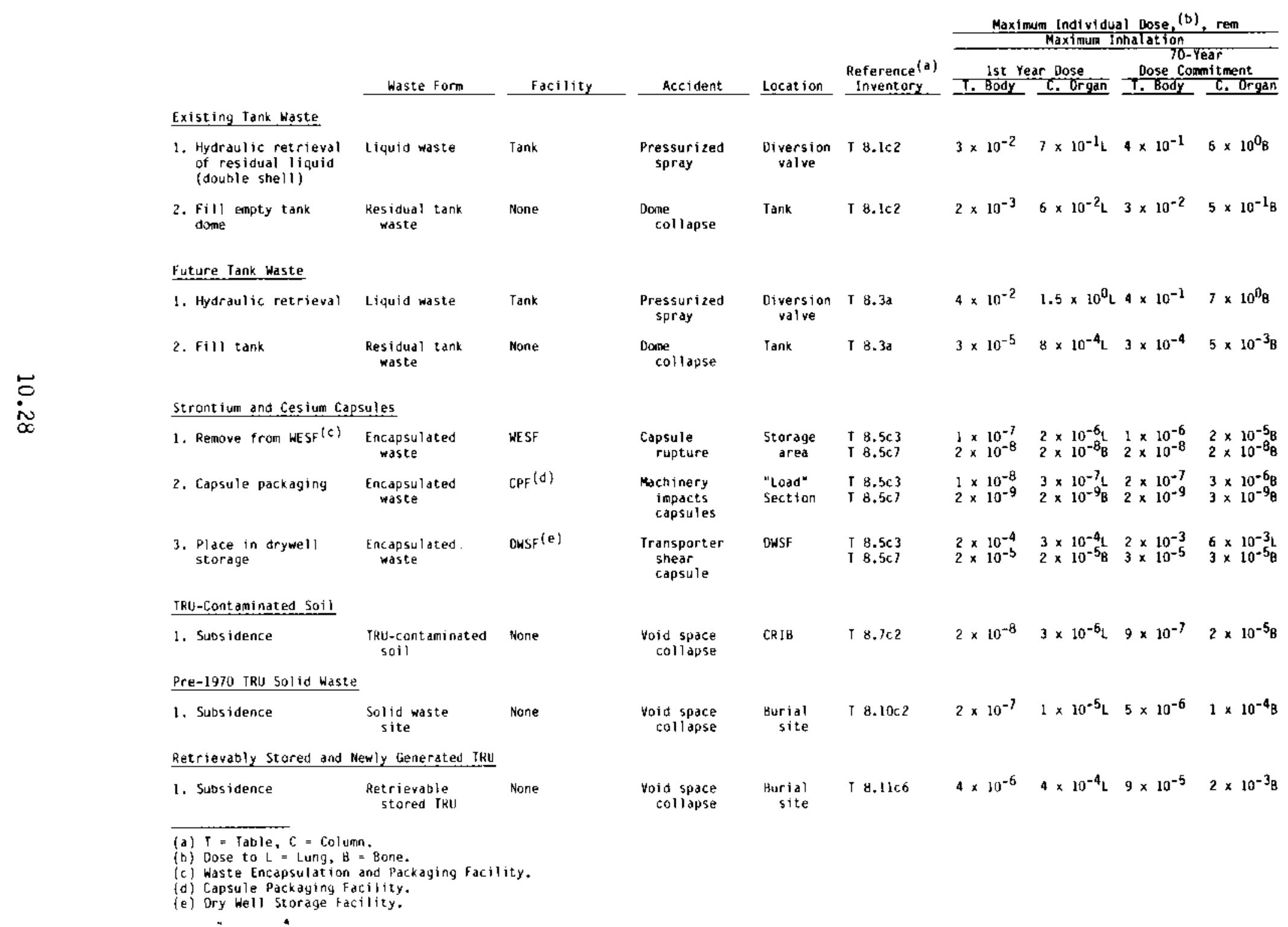


TABLE 10.7b. No Disposal Action Alternative Potential Doses from Accidental Releases for operations involving Six Waste Forms (Max. Ind. Ingestion)

\begin{tabular}{|c|c|c|c|c|c|c|c|c|}
\hline \multirow{3}{*}{ 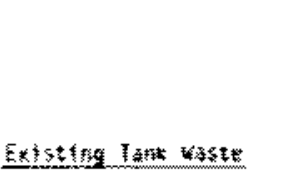 } & \multirow{3}{*}{ Anste } & \multirow{3}{*}{ 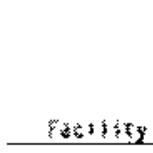 } & \multirow{3}{*}{ Atratapnt } & \multirow{3}{*}{ Lowation } & \multicolumn{4}{|c|}{ 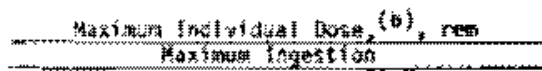 } \\
\hline & & & & & & & 70 & \\
\hline & & & & & $1+8668$ & $\mathrm{E}^{2}+\mathrm{z}$ & I. & 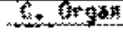 \\
\hline 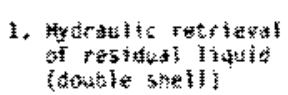 & 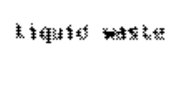 & Fank & $\begin{array}{l}\text { Pressurizzet } \\
\text { spray }\end{array}$ & 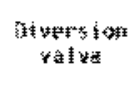 & 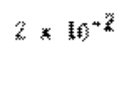 & 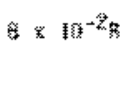 & $\$ * m^{4}$ & $2 \times 10^{6} \mathrm{c}_{\mathrm{S}}$ \\
\hline 2. Fin maty tân & 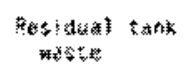 & were & $\begin{array}{l}\text { Gare } \\
\text { colnopst }\end{array}$ & 栔镂 & $2 \times 1 x^{2}$ & 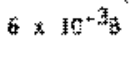 & $4 \times 19^{-7}$ & $1 \times 11^{-z_{8}}$ \\
\hline
\end{tabular}

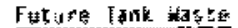

\begin{tabular}{|c|c|c|c|c|c|c|c|c|}
\hline 1. Hydraul is rectional & thquid waste & Tank & $\begin{array}{c}\text { Fressurized } \\
\text { spray }\end{array}$ & $\begin{array}{c}\text { bl versiont } \\
\text { value }\end{array}$ & $\Leftrightarrow \times 10^{-2}$ & $1 \times 1 \hat{w}^{+1}$ & $y \times 10^{-1}$ & $6 \times 10^{0_{2}}$ \\
\hline 2. Fill tank & $\begin{array}{l}\text { ketidud tank } \\
\text { waske }\end{array}$ & Pine & $\begin{array}{l}\text { Dofre } \\
\text { collapse }\end{array}$ & Tank & $4 \times 14^{-5}$ & $8 \times 10^{-5} \mathrm{~B}$ & $4 \times 10^{-4}$ & $1 \times 10^{-3}$ \\
\hline
\end{tabular}

\section{Stront ium and Cesiun c'ausules}

\begin{tabular}{|c|c|c|}
\hline 2. Rearisve from WESF $(x)$ & $\begin{array}{l}\text { Encosasul totited } \\
\text { waste }\end{array}$ & HESF \\
\hline 2. Cazsule fockaging & 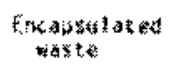 & ceptej \\
\hline 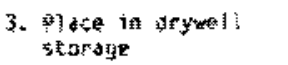 & 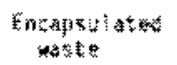 & 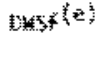 \\
\hline
\end{tabular}

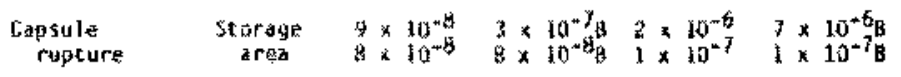

Machinery "Loat" $1 \times 10^{-13} * 4 \times 10^{* 6} 2 * 10^{-7} 9 \times 10^{-7}$

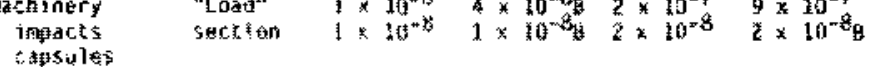

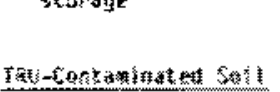

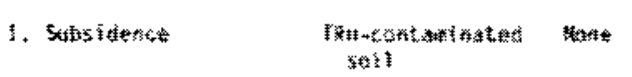

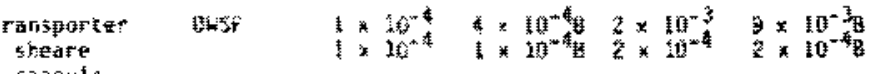

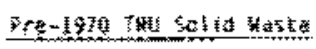

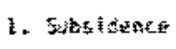

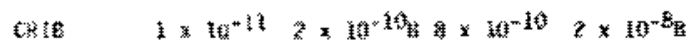

wotas space

collatyse

Dial syace

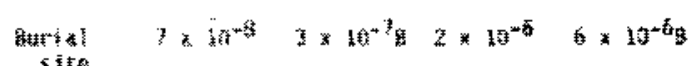

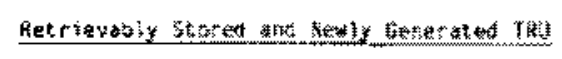

A. Sutsitionces

thit

thots

Fo:
fallapse

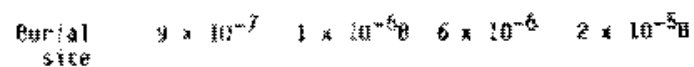

(3) $1=$ Tatite, $c$ = cotuma

(b) Dose $50 \mathrm{~b}=\mathrm{t}$ tinty, $B$ * quane.

c) Waste Encapsulation and Pakkaging factlity.

(e) Capsule Packatsing ractility 
TASLE 10.7c. No Disposal Action Alternative Potential Doses from Accidental Releases for Operations Involving \$ix Waste Forms (Total Population Dose)

\begin{tabular}{|c|c|c|c|c|c|c|c|c|}
\hline \multirow[b]{3}{*}{ Existiny Pan waste } & \multirow[b]{2}{*}{ Siasle form } & \multirow[b]{2}{*}{ facility } & \multirow[b]{2}{*}{ Actident } & \multirow{2}{*}{ Locatige } & \multicolumn{4}{|c|}{ Population Doset, to matioren } \\
\hline & & & & & In & $\frac{\text { ar bose }}{\text { C. Wrofin }}$ & $\begin{array}{r}\text { Dose } \\
\text { Dose co } \\
\text { T. Hogy }\end{array}$ & 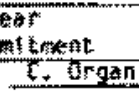 \\
\hline & & & & & & & & \\
\hline 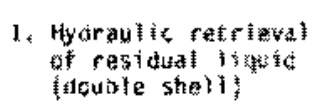 & Liquiat wasza & Tank & $\begin{array}{l}\text { Pressurized } \\
\text { speryy }\end{array}$ & $\begin{array}{c}\text { Civersion } \\
\text { value }\end{array}$ & $1 \times \sqrt{y_{i}^{2}}$ & $2 \times 10^{3} \mathrm{~L}$ & $z * 10^{3}$ & $2 \times 10^{4} y_{3}$ \\
\hline 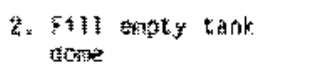 & $\begin{array}{c}\text { Resitual tank } \\
\text { Hăstete }\end{array}$ & was & bexentage & Tanik & $3 \times 10^{0}$ & $1 \times \tan ^{2}$ & $2 \times 10^{2}$ & $x \times 17^{2}$ \\
\hline
\end{tabular}

\section{Future lank waste}

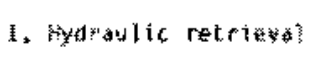

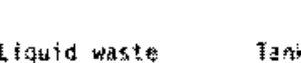

Pressumi wed speray

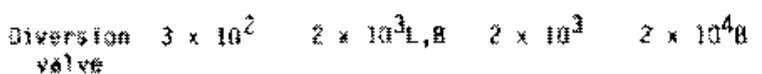

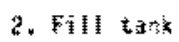

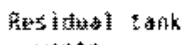

tone

Cothen

Collupse

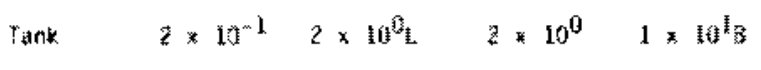

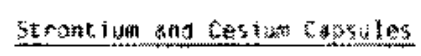

\begin{tabular}{|c|c|}
\hline 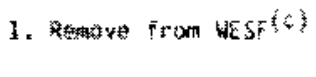 & $\begin{array}{l}\text { NFagsulated } \\
\text { *aste }\end{array}$ \\
\hline 2. tapsizie packaginy & $\begin{array}{c}\text { Encapsulatesta } \\
\text { wate }\end{array}$ \\
\hline
\end{tabular}

Camsutate

Machinaty intpacts

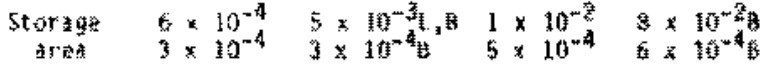

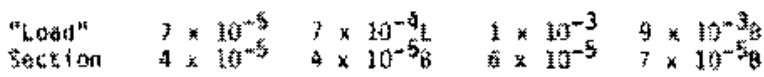

\section{IRU-iontamindted Soil}

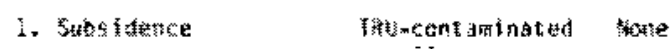
soil

toid Sylath

CRIO

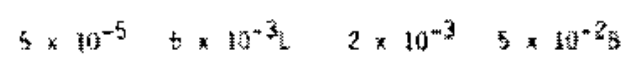

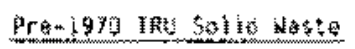

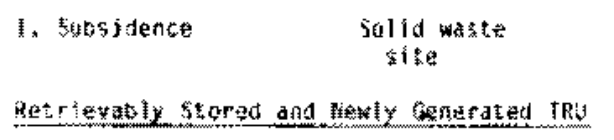
1. Subsiduffee
Tार:
None

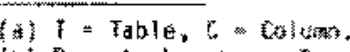

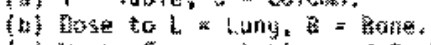

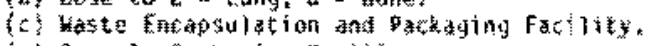

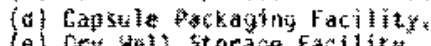

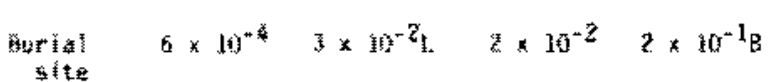

stisi space

Void spice

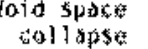

צimfol

$$
1 \times 10^{-2} \quad y \times 10^{-1} \mathrm{~L} \quad z \times 10^{-1} \quad 4 \times 10^{3}
$$




\subsection{REFERENCES}

Albrethsen, A, E, and L. C. Schwendman. 1967. Volatilization of Fission Products from Hifh-Level hastes. BNwL-338, Pacific Northest Laboratory, Rehland, Washington.

Beite1, G. A. 1976. Sodium Nitrate Combustion Limit Tests. ARH-LD-123, Atlant ic Richfield tanford Company, Richland, Washington.

Braden, D. E., C. B. Faster, J. R. Houston, G. R. Kiel, R. A. Watrous, and R. A. Zinsli. 1971. Safety Analys is Report, Waste Encapsulation and Storage Facilittes, ARH-1986, AtTantic kichfield Hanford Company, Richland, Washington.

Christian, d. D, R. E. Girton, B. E. Kirstein, and D. T. Pence, 1978. RaD for an Off-Gas Treatment System for a Slagging Pyrolysis Radioactive Waste Incinerator. Final Report for Phase II, SAI 78-904-LJ, Science Applications, Inc.: La Jolla, California

Clayton, E. D. 1974. "Anomalies of Criticallty." Nuclear Technology. 23:14-27.

Close, D. A., T. E. Booth, and J. T. Caldwe11. 1981. Criticality Calculations and Criticallity Monitoring Studies of the 51 agging pyrolys is IneTnerator Facility. LA-B336-MS, Los Alanos Scientiflc Laboratory, Los Alamos, New Mexico.

Department of Energy (DoE). 1979. Environmental and Other Evaluations of A] ternatives for Long-Term Management of Stored INLL Transuranic Waste. DOE/ET-0081, U.S. [0E, Office of Nuclear Waste Management, Washington, $\mathrm{D}$.C.

Departnent of Energy (DOE). 1982, Final Environmental Impact Statement, Defense Waste Processing Facillity, Savannah River Plant, Aiken, Sc. DOE/LT-0082, U.S. DOE, Dffice of Defense Waste and Byproducts Managenent, Washington, D.C.

Energy Research and Development Administration (ERDA). 1975. Final Environmental Impact statement on Waste Management Operations, Hanford Reservam TIOn. ERDA-1536, Washington, 0.C.

Energy Systers Group (ESG). 1980. Technical Aspects of Long-Term Managenent A1ternatives for High-Level Defense vaste at the Hanford Site: RHO-LD-141, Rockwell Hanford Operations, Richland, Washington.

Geiger, J.F., D, J. Brown, and R. E. Isacson. 1977. Assessment of Hanford Burial Grounds and Interim TRU Starage, RHO-CD-78, Rev*, Rockwell Hanford Operation, Richland, Washington. 
Gray, W. J. 1976. Volatility of a Zinc Borosilicate Glass Containing Sinulated High-Level Radioactive Waste. BKWL-2IIT, Pacific Horthwest Laboratory, Richlind, Washington.

Harness, J.L., and J. D. Mcxinney. 1977. Contaiment of Transufanic Contamination at the Early Waste Retrieval Project. TREE-I061, EG\&G Idaho, Int.; Tdaho Falls, Idaho.

Hayward, W. M., and R. J. Jensen. 1980. Environmental Aspects of Long-term Managenent Alternatives for High-Level Defense Waste at the Hanford Site. RHO-LD-140, Rockwell Hanford Operations, Richland, washington.

Houston, J.R,, 0. L. Strenge, and E. C. Watson, 1974, DACRIN--A Computer Program for Calculating organ Dose from Acute or Chronic Radionuclide Inhalation. BHiL-B-389. Pacific Northwest Laboratory, Richland, Washington.

Kirstein, B. E., W. J. Paplawsky, D. T. Pence, B. D. Snow, and M. E. Sparth. 1979. RaD for an aft-Gas Treatment System for a Slagging Pyralys is Waste Incinerator. SAI-132-79-764-[J, Science Applications, Inc , san biego, CaTifornia.

McComack, W. D., J. V. Ransdell, and B. A. Napier. 1984. Hanford Dose Dyerview Program: Standardized Methods and Data for Hanford Environmental Wose Calculations. PNL-3777, Rev. I. Paciffic Northwest Laboratary, Richland, Washington.

McDaniel, E. W. and J. G. More. 1901. Rheological characterization of Cementitious Grouts Used to Dispose of Intermediate-Level Radioactive Waste by Hodrofracturing at dak Ridge National Laboratory. CoNf-81II22, Annual Meeting of the Materials Research Society, Boston, Massachusetts.

Mckinley, K. B., and J. D. Mckinney. 1978. Early Waste Retrleval, Interin Report. TREE-1265, EG\&G Idaho, Idaho Falls, Idaho.

Mendel, J, E*, R. D. Nelson, R. P. Turcotte, W. J. Gray, M. D. Merz, F. P. Roberts, W. J. Weber, J. H. Westik, Jr., and O. E. Clark. 1981. A Statemof-the-Art Review of Material Properties of Nuclear Waste Forms. PNL-3802, Pacific Vorthwest Laboratory, Rich and, Washington.

Mishima, 1. 1975. "Data Useful in the Evaluation of Airborne Plutonfum from Postulated Accident Scenarios." Appendix $F$ in Considerations in the Assessment of the Consequence of Effluents from Mixed oxide Fuel Fabriaction Plants. ENWL-1697, Pacific Northwest Laboratory, Richland, Washington.

Mishina, J., and J. E. Ayer. 1981. Estimated Airborne Release of Radionuclides from the dattelle Menorial Institute Columbus Laboratories $\mathrm{JN}-1 \mathrm{~b}$ Building at the West defferson st te as a kesult of Postulated damade from Severe Wind and Earthquake Hazard. PML -4095 , Pacific Northwest Laboratory, Richland, washington. 
Mishima, J., and L. C. Schwendiman. 1973. Fractional Airborne Release of Uranium (Representing Plutonium) During the Burning of Contaminated Wastes. BNWL-1730, Pacific Northwest Laboratory, Richland, Washington.

Mulkin, R. 1975. Characterization of Transuranic Solid Wastes from a Plutonium Processing Facility. LA-5993-MS, Los Alamos Scientific Laboratory, Los Alamos, New Mexico.

Murphy, E. S., and G. M. Holter. 1980. Technology, Safety and Costs of Decomissioning a Reference Low-Level waste Burial Ground. NUREG/CR-0590, Pacific Northwest Laboratory, Richland, Washington.

Murthy, K. S., L. A. Stout, B. A. Napier, A. E. Reisenauer, and D. K. Landstrom. 1983. Assessment of Single-Shell Tank Residual Liquid Liquid Issues at Hanford Site, Washington. PNL-4688, Pacific Northwest Laboratory, Richland, Washington.

Napier, B. A. 1981. Standardized Input for Hanford Environmental Impact Statements, Part I. PNL-3509, Pacific Northwest Laboratory, Richland, washington.

Napier, B. A., W. E. Kennedy, Jr., and J. K. Soldat, 1980. PABLM--A Computer Proyram to Calculate Accumulated Radiation Dose from Radionuclides in the Environment. PNL-3209, Pacific Northwest Laboratory, Richland, Washington.

Oak Ridye National Laboratory (ORNL). 1970. Siting of Fuel Reprocessing and Waste Management Facilities. ORNL-4451, Oak Ridge National Laboratory, Oak Ridge, Tennessee.

Orr, C., Jr. 1966. Particle Technology. McMillan Company, New York.

Perry, 3. H., ed. 1973. Chemical Engineers' Handbook. 5th Edition, McGrawHill Book Company, New York.

Price, K. R. et al. 1984. Environmental Surveillance at Hanford for CY 1983. PNL-5038, Pacific Northwest Laboratory, Richland, Washington.

Price, S. M., R. B. Kasper, M. K. Addition, R. M. Smith, and G. V. Last. 1979. Distribution of Plutonium and Americium Beneath the 216-Z-1A Crib: A Status Report. RH0-ST-17, Rockwell Hanford Uperations, Richland, washington.

Richardson, G. L. 1980. Deferred Processing of Hanford High-Level Wastes. HEUL-TME 80-48, Hanford Engineeriny Vevelopment Laboratory, Richtand, Washington.

Rockwell Hanford Operations (RHO). 1980. Technical Status Report on Environmental Aspects of Long-Term Management of High-Tevel Defense Waste at the Hanford Site. RHO-LU-139, Rockwell Hanford Operations, Richland, Washington. 
Rockwell Hanford Operations (RHO). 1984. Transuranic Aqueous Waste Projections from the Plutonium Finishing Plant and Related Data for the Hanford Defense Waste Environmental Impact Statement, letter to J. D. White, Waste Management Division, Richland Operations Office, Rockwell Hanford Operations, Richland, Washington.

Rockwell Hanford Operations (RHO). 1985. Hanford Defense Waste Alternatives: Engineering Support Data for the HOW-EIS. RHO-RE-ST-30, Rockwel 1 Hanford Operations, Richland, Washington.

Sehmel, G. A. 1979. Deposition and Resuspension Processes. PNL-SA-6746, Pacific Northwest Laboratory, Richland, Washington.

Sinclair, P. C. 1976. "Vertical Transport of Desert Particulates by Dust Devils and Clear Thermals." Proceedings of the Atmosphere-Surface Exchange of Particulates and Gaseous Pollutants--1974 Symposium. USEROA CONF-740921, National Technical Information Service, Springfield, Virginia.

Sommer, D. J., R. G. Rau, and D. C. Robinson. 1981. Population Estimates for the Areas Within a 5U-Mile Radius of Four Reference Points on the Hanford Site. PNL-4010. Pacific Northwest Laboratory, Richland, Washington.

Steindler, M. J., and W. B. Seefeldt. 1980. "A Method for Estimating the Challenge to an Air Cleaning System Resulting from an Accidental Explosive Event." In Proceedings of the 16th DOE Nuclear Air Cleaning Conference, CUNF-801038, National Technical Information Service, Springfield, Virginia.

Stone, W. A., D. E. Jenne, and J. M. Thorp. 1972. Climatology of the Hanford Area. BNWL-1605, Pacific Northwest Laboratory, Richland, Washington.

Stone, W. A., J. M. Thorp, U. P. Gifford, and D. J. Hoitink, 1983. Climatological Summary for the Hanford Area. PNL-4622, Pacific Northwest Laboratory, Richland, Washington.

Strenge, D. L., W. D. McCormack, R. L. Dirkes, K. R. Price, and P. A. Eddy. 1975. DACRIN-Modification for Gastrointestinal Tract Dose. BNWL-B-399, Pacific Northwest Laboratory, Richland, Washington.

Strenge, D. L., B. A. Napier, R. A. Peloquin, and M. G. Zimmerman. 1980. ALLDOS - A Computer Proyran for Calculation of Radiation Doses from Airborne and Waterborne Releases. PNL-3524, Pacific Northwest Laboratory, Richland, Washington.

Strenye, D. L., E. C. Watson, and J. R. Houston. 1975. SUBO0SA - A Computer Program for Calculating External Doses from Accidental Atmospheric Releases of Radionuclides. BNWL-B-351, Pacific Northwest Laboratory, Richland, Washington.

Sula, M. J., and P. J. Blumer. 1981. Environmental Status of the Hanford Site for CY-1980. PNL-3728. Pacific Northwest Laboratory, Richland, Washington. 
Sula, M. J., W. D. Mccormack, R. L. Dirkes, K. R, Price, and P. A. Eddy. 1982. Envi ronmental Survelllance at Hanford for CY-1981. PNL-1211, Pacific Northwest Laboratory, Richland, washington.

Sula, M. J., J. M. V. Carllle, K. R. Price, and W. 0. McCormack. 1983. Environmental Surveillance at Hanford for CY-1982. PNL-4657, Pacific Northwest Laboratory, Richland, Washington.

Sutter, S.L. 1980. Potential Airborne Release from Soil Working Operations in contaminated Area. PNL-3498, Pactfic Northwest Laboratory, Richland, Washington.

Sutter. S. L. 1983. Aerosals lenerated by Releases of Pressurjzed Powders and Solutions in Static Alr. NUREG/CR-3093, U.5. Nuclear Regulatory Comission, Wasnington, D.C.

Sutter, S. L., J.W. dohnston, and J. Mishima. 1981. Aerosols Generated by Free fall spills of Powders and Solutions in Static Air. MUREG/CR-2139, PNL-3786, U.S. Nuclear Regulatory Commission, whshington, D.C.

Walmsley, 0., B. A. Sammons and J.R. Grover, 1969. Wolatillty studies of Glasses for the Fingal Brocess. AERE-k-277, Atomic Energy lesearch Establishment at Harwell. England. 


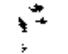

a 
PNL-5356

UC- 70

DISTRIBUTION

No. of

Copies

OFFSITE

T. C. Chee

Office of Waste Operations

and Technology

DOE Nuclear Waste Management

NE-320, GTN

Washington, DC 20545

R. Pelletier

DOE Nuclear Waste Policy Act

Project Office

S-10 Forrestal

Washington, DC 20585

C. E. Jenkins

Science Applications Corporation

1835 Termina 1 Dr. Ste. 240

Richland, WA 99352

30 DOE Technical Information Center

\section{ONSITE}

7 DOE Richland Operations office

E. A. Bracken

R. A. Holten (5)

J. D. White

25 Rockwell Hanford Operations

C. Defigh-Price (4)

C. J. Geier

R. T. Wilde (20)

Human Affairs Research Center

S. L. Stein
No. of ?

Copies

49 Pacific Northrest Laboratory

J. B. Burnham (10)

D. W. Dragnich

B. D. Hadlock (9)

K. A. Hawley

W. W. Laity

N. S. Laulainen

S. F. Liebetrau

J. Mishima (10)

B. A. Napier

I. C. Nelson

M. G. Piepho

G. H. Sewart

J. G. Stephan

J. A. Stottlemyre

H. H. Van Tuyl

E. C. Watson

Publishing Coordination (2)

Technical Information (5) 
